\title{
A Multiphoton Single-Electron Reduction of Olefins via Tandem Photoredox Catalysis
}

Tyra Horngren, Mitchell S. Taylor, Milena Czyz, Anastasios Polyzos

Submitted date: 03/05/2020 - Posted date: 05/05/2020

Licence: CC BY-NC-ND 4.0

Citation information: Horngren, Tyra; Taylor, Mitchell S.; Czyz, Milena; Polyzos, Anastasios (2020): A Multiphoton Single-Electron Reduction of Olefins via Tandem Photoredox Catalysis. ChemRxiv. Preprint. https://doi.org/10.26434/chemrxiv.12235928.v1

Herein we report a visible light multiphoton tandem photoredox catalysis strategy enabling a distinctive mode of olefin activation via a one electron reduction to the corresponding radical anion. This highly nucleophilic intermediate was harnessed to develop a method for the formal hydrogenation of unactivated alkenes under mild reaction conditions, in the absence of hydrogen gas or dissolving metals.

File list (3)

Polyzos_Tandem_Photoredox_Olefin_Reduction.pdf (520.66 KiB) view on ChemRxiv • download file TOC.pdf (43.39 KiB) view on ChemRxiv • download file

SI_Polyzos_Tandem_Photoredox_Olefin_Reduction.pdf (19.03 MiB) view on ChemRxiv - download file 


\title{
A Multiphoton Single-Electron Reduction of Olefins via Tandem Photoredox Catalysis
}

\author{
Tyra H. Horngren, ${ }^{\dagger \ddagger}$ Mitchell S. Taylor, ${ }^{\dagger \ddagger}$ Milena L. Czyz, ${ }^{\dagger}$ and Anastasios Polyzos ${ }^{\dagger \S *}$ \\ † School of Chemistry, The University of Melbourne, Parkville 3010, Victoria, Australia; § CSIRO Manufacturing, Research Way, Clayton VIC 3168, \\ Australia
}

Abstract: Regio- and chemoselective functionalization of alkenes, through the catalytic activation of $\pi$ bonds, is a key approach for the synthesis of complex $\mathrm{sp}^{3}$-rich molecular scaffolds. Herein we report that the visible light multiphoton promoted tandem photoredox catalysis of $\left[\operatorname{Ir}(\mathrm{ppy})_{2}(\mathrm{dtb}-\mathrm{bpy})\right]^{+}$enables a distinctive mode of olefin activation through one electron reduction to the corresponding radical anion. This highly nucleophilic intermediate was harnessed to develop a method for the formal hydrogenation of unactivated alkenes under mild reaction conditions, in the absence of hydrogen gas or dissolving metals.

\section{Introduction}

The hydrofunctionalization of olefins, including formal reduction to alkanes, enables the preparation of diverse and complex sp ${ }^{3}$ architectures from the more readily available $\mathrm{sp}^{2}$-hybridized scaffolds. ${ }^{1}$ Accordingly, strategies for the regio- and chemoselective functionalization of $\pi$ systems have become essential transformations in synthetic organic chemistry. ${ }^{2}$ A variety of strategies exist to enhance electrophilicity of $\pi$ systems. The fundamental approach involves initial protonation with a strong acid to generate a carbocation or a bridged intermediate, followed by a nucleophilic attack on the more electron-rich carbon of the double bond (Markovnikov addition). ${ }^{3}$ Furthermore, addition reactions mediated or catalyzed by transition metals have provided a range of methodologies with predictable and controllable Markovnikov and anti-Markovnikov reactivity patterns. ${ }^{3 b, 4} \mathrm{~A}$ more recent and attractive activation mode involves one electron oxidation of olefins using highly oxidizing photoredox organocatalysts to generate radical cations, ${ }^{5}$ which then react with nucleophiles with complete anti-Markovnikov regioselectivity (Figure 1a (i)). ${ }^{6}$

a Established Olefin Photochemistry

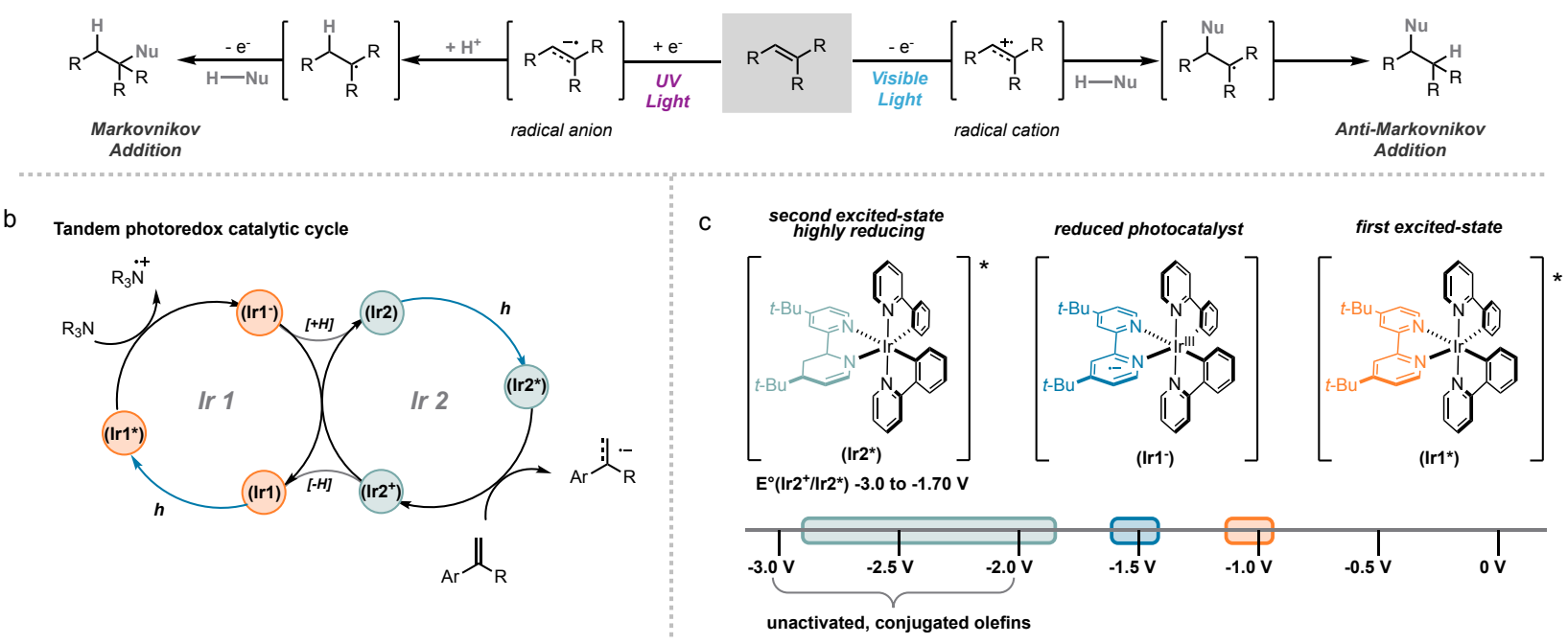

d This Work: Harnessing Reactivity of Olefin Radical Anions

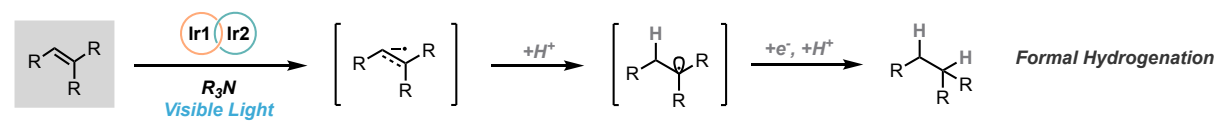

Figure 1: Activation of olefins enabled by tandem photoredox catalysis. (a) previous work on olefin activation through a photocatalytic one electron transfer (b) the concept of tandem photoredox catalysis of $\left[\operatorname{Ir}(\mathrm{ppy})_{2}(\mathrm{dtb}-\mathrm{bpy}) \mathrm{PF}_{6}(\mathrm{c})\right.$ comparison of redox potentials of the first and second excited states of $\left[\mathrm{Ir}(\mathrm{ppy})_{2}\left(\mathrm{dtb}-\mathrm{bpy}_{\mathrm{f}}\right)_{\mathrm{PF}} \mathrm{F}_{6}\right.$ (d) Harnessing reactivity of olefin radical anions for formal hydrogenation of unactivated olefins. 
Activation of olefins by direct, one-electron reduction to the corresponding radical anion could provide a distinctive mode for the functionalization of double bonds with weak electrophiles. Radical anions derived from conjugated alkenes have been reported to be highly nucleophilic in character, ${ }^{7}$ however their chemistry remains unexplored. Electrochemical and dissolving metal reductive pathways result in complex mixtures of hydrogenation and dimerization products. ${ }^{8}$ Photochemical approaches ${ }^{9}$ remain scarce due to the highly negative reduction potentials of unactivated olefins (<-2.0 V vs SCE) which remains outside the scope of conventional photoredox catalysts. Furthermore, the scope has been limited to Markovnikov addition products due to facile oxidation of the benzylic radical by back electron transfer to the catalyst (Figure $1 \mathrm{a}(\mathrm{ii})) .^{7 \mathrm{~b}, 10}$

We envisioned that generation of olefin radical anions could provide a general strategy to enhance the weakly nucleophilic character of unactivated $\pi$ systems. ${ }^{11}$ This activation strategy could open up new avenues for the hydrofunctionalization of double bonds, especially transfer hydrogenation to alkanes, if the downstream reactivity of the radical anion could be effectively controlled to suppress dimerization and oxidation pathways.

Multiphoton excitation catalysis has emerged as a new strategy to overcome the thermodynamic limitations of visible light photoredox catalysis by generating high energy photoreductants. ${ }^{12}$ Our group recently disclosed a method for the in-situ generation of a second highly reducing iridium photocatalyst from $\left[\operatorname{lr}(\mathrm{ppy})_{2}(\mathrm{dtbpy})\right]^{+}$via a 2-photon tandem photoredox cycle ${ }^{13}$ (Figure $\left.2 \mathrm{a}\right)$. Nicewicz and coworkers have also uncovered similar behaviour with organophotoredox catalysts. ${ }^{14}$ This strategy has been successfully applied to the reductive protodehalogenation of unactivated organohalides and showcases the ability of common photoredox catalysts to yield potent excited-state donors via multiphoton excitation. We hypothesized that the in-situ generated highly rediucing iridium catalyst (Ir2*) was ideally suited to promote the single electron olefin reduction with requisite reactivity control to generate the corresponding alkane. ${ }^{13}$

Reported here is the first example of a general and practical strategy for the photoredox catalyzed reduction of conjugated, unactivated olefins via a single electron pathway. The tandem catalytic cycle of $[\operatorname{lr}(\mathrm{ppy}) 2(\mathrm{dtb}-\mathrm{bpy})]^{+}$engages energy demanding olefins via a multiphoton initiated secondary catalytic cycle to furnish the corresponding alkane through effective control of radical anion reactivity without competitive oxidation and dimerization pathways. This versatile activation mode furnishes a mild method for the chemoselective reduction of olefins in the absence of hydrogen gas, or dissolving metals, at room temperature, using only visible light as the energy source.

\section{Results and Discussion}

The design plan is shown in figure $1 \mathrm{~b}$ and $\mathrm{c}$. Irradiation of $\left[\operatorname{Ir}(\mathrm{ppy})_{2}(\mathrm{dtb}-\mathrm{bpy})\right] \mathrm{PF} \mathrm{F}_{6}(\operatorname{Ir} 1)$ in the presence of triethylamine $(\mathrm{TEA})$ leads to semi-saturation of the dtb-py ligand, generating a highly reducing species Ir2 (Figure 1b). We propose that one electron transfer from Ir2 to a conjugated olefin such as 1,1-diphenylethylene $\left(E_{\text {red }}{ }^{\prime}\right.$ ' $=-2.25 \mathrm{~V}$ vs SCE) generates a radical anion, that is immediately protonated to give a stable benzylic radical. In the presence of TEA radical cation, an effective hydrogen atom donor (BDE $=42 \mathrm{kcal}^{\mathrm{mol}}{ }^{-}$ $\left.{ }^{1}\right),{ }^{15}$ the radical undergoes a hydrogen atom transfer (HAT) to yield the desired alkane. Alternatively, a consecutive photoinduced electron transfer (conPET) $)^{16}$ from Ir2 to the radical intermediate $\left(E_{1 / 2}{ }^{\text {red }}=-1.34 \mathrm{~V} \text { vs SCE }\right)^{17}$ generates a second carboanion, which is quenched by a proton source. We hypothesized that in the presence of a highly reducing Ir2 catalyst, and an excess of triethylamine as the reductive quencher, the oxidation pathway $\left(E_{1 / 2}{ }^{0 x}=+0.23 \mathrm{~V}\right.$ vs SCE) will be suppressed in favour of either HAT or conPET pathways, to yield products of the formal hydrogenation of alkenes (Figure 1d).

We began our investigation into the photoredox catalyzed reduction of olefins using 1,1-diphenylethylene 1 as model substrate. Substrate 1 was combined with triethylamine (TEA) in methanol and irradiated with $80 \mathrm{~W}$ blue LEDs (440 nm) for 24 hours. The desired product was detected in $14 \%$ yield, with the full consumption of the starting material observed by ${ }^{1} \mathrm{H}$ NMR spectroscopic analysis of the crude reaction mixture (Table 1, entry 1). Other alcoholic solvents were less effective, likely due to poor solubility of the catalyst and 
the substrate (Table 1, entry 2). On the other hand, replacing triethylamine with diisopropylethylamine (DIPEA) improved the yield to $37 \%$, while addition of water to the solvent system further increased the yield to $55 \%$.

Table 1: Optimization and Control Experiments ${ }^{\mathrm{a}}$

\begin{tabular}{|c|c|c|}
\hline & $\begin{array}{c}\mathrm{Et}_{3} \mathrm{~N}(2.2 \text { equiv. }) \\
{\left[\operatorname{lr}(\mathrm{ppy})_{2}(\mathrm{dtbbpy})\right] \mathrm{PF}_{6}(2 \mathrm{~mol} \%)} \\
\mathrm{MeOH}[0.1 \mathrm{M}], \mathrm{rt} \\
80 \mathrm{~W} 440 \mathrm{~nm} \text { LEDs }\end{array}$ & \\
\hline Entry & Deviation from the above conditions & Yield [\%] ${ }^{b}$ \\
\hline 1 & - & 14 \\
\hline 2 & Ethanol & 7 \\
\hline 2 & 1,2,2,6,6-pentamethylpiperidine & 10 \\
\hline 3 & Tributylamine & 6 \\
\hline 4 & Diisopropylethylamine & 37 \\
\hline 5 & Diisopropylamine; $\mathrm{MeOH} / \mathrm{H}_{2} \mathrm{O}(9: 1)$ & 55 \\
\hline 6 & Diisopropylamine; $\mathrm{MeOH} / \mathrm{H}_{2} \mathrm{O}$ (9:1) Formic acid (2.8 equiv.) & $82(80)^{d}$ \\
\hline 7 & Diisopropylamine; $\mathrm{MeOH} / \mathrm{H}_{2} \mathrm{O}$ (9:1) Formic acid (3.0 equiv.) & 79 \\
\hline 8 & No photocatalyst & ND \\
\hline 9 & No tertiary amine & ND \\
\hline 10 & No light & ND \\
\hline 11 & Bis(tetrabutylammonium)oxalate as the reductive quencher & ND \\
\hline
\end{tabular}

[a] General conditions: Olefin 1 (1.0 equiv.), Et $3 \mathrm{~N}$ (2.2 equiv.), $\mathrm{MeOH}\left(0.1 \mathrm{M}\right.$ in substrate), sparged with $\mathrm{N}_{2}$ for 5 minutes; $24 \mathrm{~h}$ [b]

Yield determined by ${ }^{1} \mathrm{H}$ NMR spectroscopy using sulfolene as an internal standard. [d] isolated yield. ND = Not Detected

Analysis of the crude reaction mixture revealed that yield was diminished by the formation of an $\alpha$-amino adduct 3 (see SI, Table S1 for details), likely promoted by electrostatic interaction between the radical cation of DIPEA and the radical anion of the olefin $1 .{ }^{18}$ Consequently, formic acid was added to the reaction mixture, to convert DIPEA into its formate salt and thus prevent formation of $\alpha$ amino radicals. ${ }^{19}$ Pleasingly, addition of a slight excess of formic acid relative to DIPEA improved the yield to $82 \%$, with no traces of the $\alpha$-amino adducts detected in the ${ }^{1} \mathrm{H}$ NMR spectrum of the crude reaction mixture (Table 1, entry 6 ). Higher loadings of formic acid had an adverse effect on the reaction (Table 1, entry 7), due to the resulting decomposition of the iridium photocatalyst. Finally, control experiments (Table 1, entries 8-10) confirmed that no reaction occurred in the absence of photocatalyst, tertiary amine or visible light, consistent with the proposed reaction mechanism. Furthermore, replacing DIPEA with bis(tetrabutylammonium)oxalate, which is known to reduce Ir $1^{*}$ without generating $\operatorname{Ir} 2,{ }^{13}$ led to full recovery of the starting material and no trace of the reduced product 2 (Table 1 , entry 11).

With the optimized reaction conditions established, we next sought to evaluate the generality of the developed method by examining the effect of variations in the 1,1-diphenylethylene motif (Figure 2). The reaction was not sensitive to electronic effects; high yields were obtained for both electron-withdrawing (Figure 2, 4-10) and electron-donating substituents (Figure 2, 12-17), which suggested that the highly reducing tandem photoredox catalytic cycle of Ir successfully supressed oxidation of the benzylic radical and subsequent Markovnikov addition for most substrates. Functionality at the ortho, meta or para positions was well-tolerated. The reaction was compatible with fluorinated and trifluoromethylated substrates $\mathbf{4}$ and $\mathbf{5}$. Notably, full chemoselectivity observed in the presence of other reducible functionalities including chloro, nitrile, ester and amide functional groups (Figure 2, 7-11 and 37). Furthermore, electron poor heterocyclic derivative was tolerated with the reduction of the pyridyl derivative $\mathbf{1 2}$ proceeding in a good yield. 


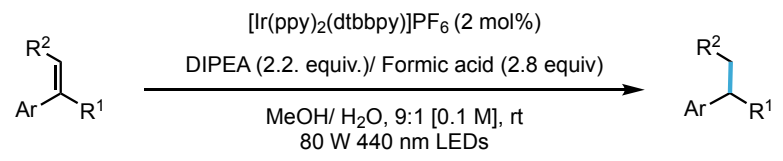

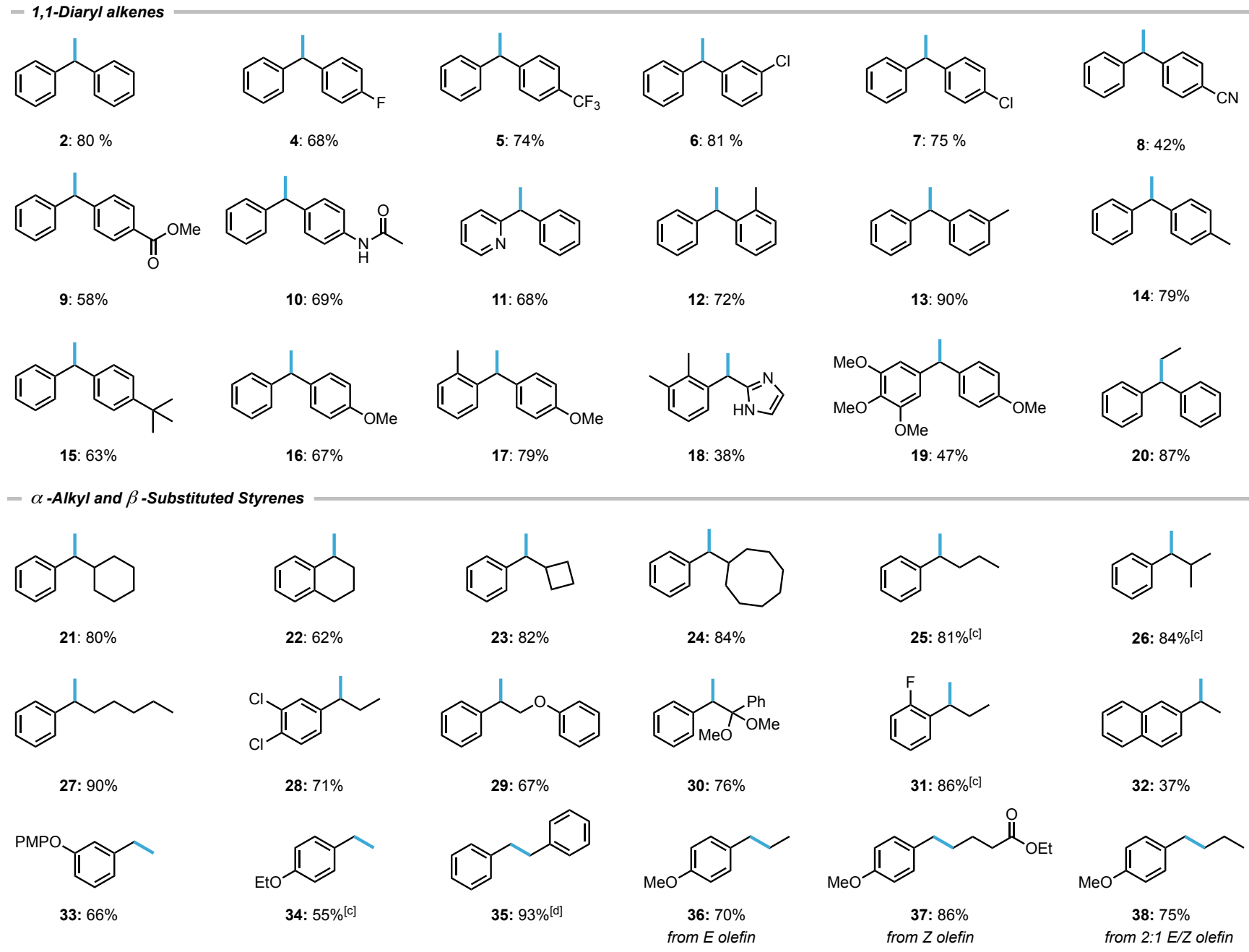

Figure 2: Tandem photoredox catalyzed formal hydrogenation of olefins ${ }^{a, b}$ [a] General conditions: olefin (1.0 equiv.), [Ir(ppy) $2($ dtb-bpy)]PF 6 (2 mol\%), DIPEA (2.2 equiv.), $\mathrm{HCO}{ }_{2} \mathrm{H}$ (2.8 equiv.), $\mathrm{MeOH} / \mathrm{H}_{2} \mathrm{O} 9: 1$ (0.1 M in substrate), r.t., $24 \mathrm{~h}, 80 \mathrm{~W}$ Blue LEDs (440 nm) [b] Isolated yields. [c] ${ }^{1} \mathrm{H} \mathrm{NMR}$ yields against sulfolene as the internal standard. [d] 48 hour reaction time;

As 1,1-diarylethanes are present in numerous drug and agrochemical targets, ${ }^{20}$ we synthesised two biologically active molecules, pesticide $18^{20 a}$ and anti-cancer agent isoerianin $19^{21}$ by reduction of the corresponding olefins. These unoptimized yields in this reaction represent the first example of direct access to these valuable targets from the corresponding olefins in the absence of hydrogen gas. ${ }^{20 d}$ Finally, reduction of sterically hindered, trisubstituted olefin $\mathbf{2 0}$ proceeded in an excellent yield of $87 \%$.

Next, we turned our attention to extending the scope beyond biaryl derivatives by investigating less activated, $\alpha$-alkyl substituted styrenes. Both carbocyclic rings (21-24) and open chain alkyl derivatives (25-32) afforded the corresponding saturated products in good to excellent yields. Longer alkyl chains and branched alkyl chains were all well tolerated. $\alpha$-Methyl substituted styrenes such as $\mathbf{3 2}$ were compatible with reaction conditions, however proved challenging to isolate due to high volatility of the reduced products. Simple, unsubstituted styrenes $\mathbf{3 3}$ and $\mathbf{3 4}$ were reduced in good yields. On the other hand, trans-stilbene reacted slowly despite accessible redox potential $\left(E_{1 / 2}=-2.17\right.$ vs SCE in DMF); ${ }^{7 a}$ cis-stilbene, likely formed through a competing energy transfer pathway, ${ }^{12 d, 22}$ was the major product after 24 hour reaction time, yet full conversion was observed after 48 hours. Conversely, $\beta$-alkyl substituted styrenes converted cleanly to products $\mathbf{3 6}$ - $\mathbf{3 8}$ in excellent yields. Formation of product $\mathbf{3 6}$ (from the corresponding $E$ alkene), $\mathbf{3 7}$ (from the corresponding 
Z alkene) and product 38 (from a 2.6:1 E/Z mixture) (see Supporting Information for details) all proceeded in excellent yields, demonstrating that both $E$ and $Z$ olefins are highly reactive under reaction conditions.

\section{Mechanistic studies}

Spectroscopic studies were conducted to probe the reaction mechanism and provide evidence for the formation of the radical anion through direct one electron reduction from the in-situ generated photocatalyst, Ir2*. Steady-state luminescence quenching experiments confirmed that phosphorescence intensity from the photocatalyst [Ir"II(ppy) $\left.{ }_{2}(\mathrm{dtb}-\mathrm{bpy})\right]_{\mathrm{PF}}$ (Ir1) was quenched in the presence of DIPEA, with the expected linear Stern-Volmer plot (See Figure S2B, Supporting Information). Importantly, minimal quenching of photocatalyst phosphorescence was observed in the presence of olefin 1 (Figure S2B Supporting Information). Although the reduction potential of substrate 1 is sufficiently lower than that of $\operatorname{Ir} 1^{*}\left(E^{0^{\prime}}\left({ }^{*} \mid r^{I I I} / I r^{I V}=-1.15 \mathrm{~V}\right.\right.$ vs SCE), rendering SET thermodynamically unfavourable, it is noteworthy that these two species have comparable triplet energy values (diphenylethylene $E_{\mathrm{T}}=52 \mathrm{kcal}^{\mathrm{mol}}{ }^{-1.23} \mathrm{Ir}^{-1} E_{\mathrm{T}}$ $\left.=49.2 \mathrm{kcal} \mathrm{mol}^{-1}\right) ;{ }^{24}$ however, based on luminescent quenching study and lower reactivity of substrates with long-lived triplet excited states (e.g. trans-stilbene, $E_{\mathrm{T}}=49.3 \mathrm{kcal} \mathrm{mol}^{-1}$ and $\left.\tau_{\mathrm{T}}=30 \mu \mathrm{s}\right)^{24}$ energy transfer catalysis ${ }^{12 \mathrm{~d}}$ can be excluded as a plausible reaction pathway.

Next, we sought evidence for the involvement of the second excited state of $\left[\operatorname{Ir}(\mathrm{ppy})_{2}(\mathrm{dtbbpy})\right]_{\mathrm{PF}} \mathrm{F}_{6}$, Ir2*. Consistently with previous studies, ${ }^{13}$ illumination of the solution of $\left[\operatorname{Ir}(\mathrm{ppy})_{2}(\mathrm{dtbbpy})\right] \mathrm{PF}_{6}$ in the presence of $50 \mathrm{mM}$ of DIPEA with blue light resulted in rapid quenching of the emission band at $580 \mathrm{~nm}$ and formation of a new intense emission profiles having maxima at $489 \mathrm{~nm}$ and $510 \mathrm{~nm}$, attributed to the formation of Ir2 species (Figure 3A-I). Addition of substrate 1 effectively quenched the phosphorescence of Ir2*, with the resulting linear Stern-Volmer plot having a calculated quenching rate constant of $1.7 \times 10^{8} \mathrm{M}^{-1} \mathrm{~s}^{-1}$ (Figure $3 \mathrm{~A}-\mathrm{II}$ ). This implicates Ir2* as the species responsible for the reduction of substrate 1 . We next sought to examine the nature of the interaction between substrate 1 and Ir2*

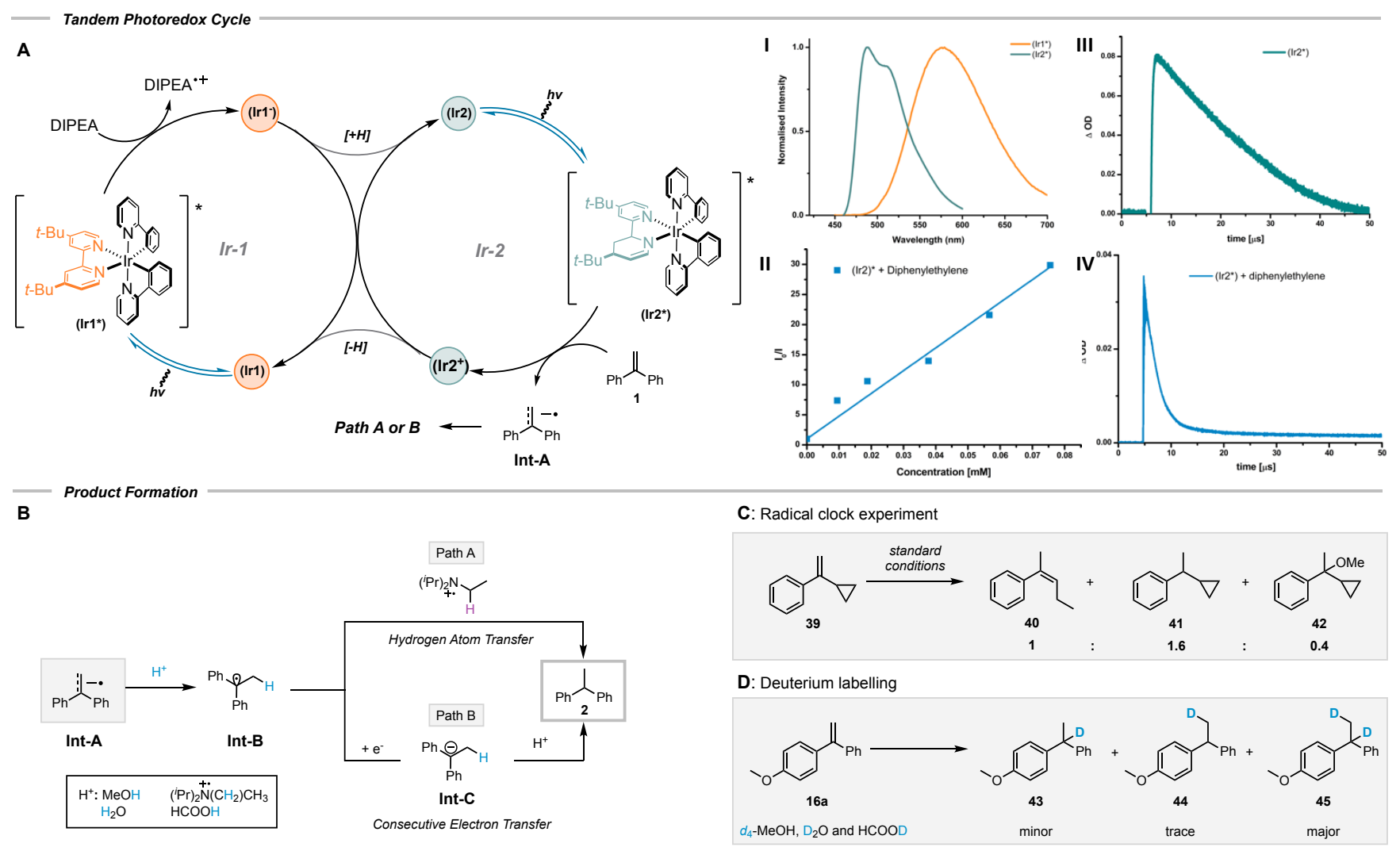

Figure 3: Mechanistic investigation; (A) Evidence for the involvement of the second excited state, Ir2 (I) formation of Ir2 under reaction conditions (II) Stern-Volmer quenching of Ir2* by substrate 1 (III) Transient Absorption decay profile of Ir2 in the absence of quencher (IV) Transient Absorption decay profile of Ir2 in the presence of quencher 1 (B) Plausible mechanistic pathways (C) Radical clock experiment (D) Deuterium labelling experiment 
using transient absorption spectroscopy. In the absence of substrate 1, the transient decay profile of Ir2* (measured at $380 \mathrm{~nm}$ and 540 $\mathrm{nm}$ ) shows full decay with the transient species assigned as the metal-to-ligand charge transfer ( ${ }^{3} \mathrm{MLCT}$ ) excited state of Ir2 (Figure 3A-III and Supporting Information, Figure S4). The transient decay profile in the presence of substrate 1 however, does not decay fully (Figure 3A-IV and Supporting Information, Figure S4) over $50 \mathrm{~ms}$, indicating electron transfer between Ir2* and alkene substrate 1. These results are consistent with an electron transfer from Ir2* to the olefin to generate a radical anion Int-A.

Radical clock experiment using (1-cyclopropylvinyl)benzene (39) (Figure 3C and Supporting Information, Figure S5) yielded ringopened product $\mathbf{4 0}$ as well as fully reduced product $\mathbf{4 1}$ and methoxy adduct $\mathbf{4 2}$. All three have been reported to derive from Int-B, which supports our hypothesis that it is the key intermediate along the main reaction pathway (Figure 3B). Next, deuterium labelling experiments were conducted to differentiate between transfer hydrogenation from DIPEA radical cation (Figure 3B, path $\mathrm{A}$ ), and a Birch-type reduction involving two consecutive photoinduced electron transfers (conPET, Figure $3 \mathrm{~B}, \mathrm{path} \mathrm{B}$ ). When $d_{4}-\mathrm{MeOH}, \mathrm{D}_{2} \mathrm{O}$ and $d$-formic acid were used under the standard reaction conditions, the major product $\mathbf{4 5}$ contained deuterium incorporation at both the distal and proximal positions; suggesting anionic character at both these positions during the reaction (Figure 3C and Supporting Information, Figure S7 - 11). Interestingly, the ratio did not significantly change when non-deuterated formic acid was used, suggesting that the only role of formic acid in this reaction is to hinder reactivity of DIPEA radical cation with the olefin. This observation confirms that water and methanol are the major sources of protons, with less than $100 \%$ deuterium incorporation observed using $\mathrm{MeOH} / \mathrm{D}_{2} \mathrm{O}$ or $d_{4}-$ $\mathrm{MeOH} / \mathrm{H}_{2} \mathrm{O}$ solvent systems (Supporting Information, Figure S13). Transfer hydrogenation via hydrogen atom abstraction or proton transfer from the radical cation of DIPEA cannot, however, be excluded as a possible reaction pathway due to the minor contribution of mono- deuterated products $\mathbf{4 3}$ and $\mathbf{4 4}$. To investigate this, $\mathrm{Et}_{3} \mathrm{~N}-\mathrm{d}_{15}$ was used under the standard reaction conditions. Unfortunately, due to the low tolerance of alternative amine sources in the reaction, conclusive results not could be drawn from these experiment. On the basis of these mechanistic studies reported herein, we assign the major reaction pathway for olefin reduction by two consecutive single electron reductions (conPET, Figure 3B, path B).

\section{Conclusion}

In summary, we demonstrated that unactivated olefins can be activated towards reaction with weak electrophiles through direct, one electron reduction utilizing a multiphoton tandem $\left[\operatorname{lr}(\mathrm{ppy})_{2} \mathrm{dtbbpy}_{\mathrm{PF}} \mathrm{F}_{6}\right.$ photoredox cycle. The highly reducing photoredox system enables reactivity control for radical anions by suppressing competitive oxidation and dimerization pathways. We demonstrated the utility of this activation mode by the chemoselective reduction of both 1,1-diaryl alkenes and alkyl substituted styrene derivatives in good to excellent yields in the absence of hydrogen gas, or dissolving metals, at room temperature, using only visible light as the energy source. This strategy now offers unique opportunities for olefin hydrofunctionalization under mild reaction conditions via a reductive radical anion pathway. Studies are currently underway in our laboratory to harness the reactivity of olefin radical anions to enable photoinduced alkene functionalization via reductive $\mathrm{C}-\mathrm{C}$ and $\mathrm{C}-\mathrm{X}$ bond forming reactions.

*Corresponding Author: anastasios.polyzos@unimelb.edu.au

\section{Acknowledements}

MLC acknowledges the ARC Industrial Transformation Training Centre Post-Doctoral Fellowship; THH acknowledges the University of Melbourne, Melbourne Research Scholarship (MRS); AP acknowledges the University of Melbourne and CSIRO for the joint Establishment Grant and the ARC (IC1701000020).

\section{References}

[1] Lovering, F.; Bikker, J.; Humblet, C., Escape from Flatland: Increasing Saturation as an Approach to Improving Clinical Success. J. Med. Chem. 2009, 52 (21), 6752-6756. 
[2] Roughley, S. D.; Jordan, A. M., The Medicinal Chemist's Toolbox: An Analysis of Reactions Used in the Pursuit of Drug Candidates. J. Med. Chem. 2011, 54 (10), 3451-3479.

[3] (a) Electrophilic Additions to Carbon-Carbon Multiple Bonds. In Advanced Organic Chemistry: Part B: Reactions and Synthesis, Carey, F. A.; Sundberg, R. J., Eds. Springer US: Boston, MA, 2002; pp 191-248; (b) Beller, M.; Seayad, J.; Tillack, A.; Jiao, H., Catalytic Markovnikov and anti-Markovnikov Functionalization of Alkenes and Alkynes: Recent Developments and Trends. Angew. Chem. Int. Ed. 2004, 43 (26), $3368-$ 3398.

[4] (a) Cristina Silva Costa, D., Additions to non-activated alkenes: Recent advances. Arab. J. Chem. 2020, 13 (1), 799-834; (b) Han, L.-B.; Tanaka, M., Transition metal-catalysed addition reactions of $\mathrm{H}$-heteroatom and inter-heteroatom bonds to carbon-carbon unsaturated linkages via oxidative additions. Chem. Commun. 1999, (5), 395-402; (c) Dupont, J.; Pfeffer, M.; Spencer, J., Palladacycles - An Old Organometallic Family Revisited: New, Simple, and Efficient Catalyst Precursors for Homogeneous Catalysis. Eur. J. Inorg. Chem. 2001, 2001 (8), 1917-1927; (d) Chianese, A. R.; Lee, S. J.; Gagné, M. R., Electrophilic Activation of Alkenes by Platinum(II): So Much More Than a Slow Version of Palladium(II). Angew. Chem. Int. Ed. 2007, 46 (22), 4042-4059.

[5] Neunteufel, R. A.; Arnold, D. R., Radical ions in photochemistry. I. 1,1-Diphenylethylene cation radical. J. Am. Chem. Soc. 1973, 95 (12) 4080-4081.

[6] (a) Margrey, K. A.; Nicewicz, D. A., A General Approach to Catalytic Alkene Anti-Markovnikov Hydrofunctionalization Reactions via Acridinium Photoredox Catalysis. Acc. Chem. Res. 2016, 49 (9), 1997-2006; (b) Wilger, D. J.; Grandjean, J.-M. M.; Lammert, T. R.; Nicewicz, D. A., The direct anti-Markovnikov addition of mineral acids to styrenes. Nat Chem. 2014, 6 (8), 720-726; (c) Romero, N. A.; Nicewicz, D. A., Mechanistic Insight into the Photoredox Catalysis of Anti-Markovnikov Alkene Hydrofunctionalization Reactions. J. Am. Chem. Soc. 2014, 136 (49), 1702417035.

[7] (a) Grimshaw, J., Chapter 3 - Reduction Of Alkenes And Conjugated Alkenes. In Electrochemical Reactions and Mechanisms in Organic Chemistry, Grimshaw, J., Ed. Elsevier Science B.V.: Amsterdam, 2000; pp 54-88; (b) Maroulis, A. J.; Shigemitsu, Y.; Arnold, D. R., Radical ions in photochemistry. 5. Photosensitized (electron transfer) cyanation of olefins. J. Am. Chem. Soc. 1978, 100 (2), 535-541.

[8] (a) Mizuno, K.; Otsuji, Y. In Addition and cycloaddition reactions via photoinduced electron transfer, Electron Transfer I, Berlin, Heidelberg, 1994//; Mattay, J., Ed. Springer Berlin Heidelberg: Berlin, Heidelberg, 1994; pp 301-346; (b) Baba, A.; Yasuda, M.; Nishimoto, Y., 8.20 Partial Reduction of Enones, Styrenes, and Related Systems. In Comprehensive Organic Synthesis II (Second Edition), Knochel, P., Ed. Elsevier: Amsterdam, 2014; pp 673-740; (c) Langan, J. R.; Salmon, G. A., Formation and dimerization of vinylic radical anions and ion pairs. A pulse radiolysis study. Journal of the Chemical Society, Faraday Transactions 1: Physical Chemistry in Condensed Phases 1983,79 (3), $589-597$.

[9] Pac, C.; Ihama, M.; Yasuda, M.; Miyauchi, Y.; Sakurai, H., Tris(2,2'-bipyridine)ruthenium(2+)-mediated photoreduction of olefins with 1benzyl-1,4-dihydronicotinamide: a mechanistic probe for electron-transfer reactions of $\mathrm{NAD}(\mathrm{P}) \mathrm{H}$-model compounds. J. Am. Chem. Soc. 1981, 103 (21), 6495-6497.

[10] (a) Weiser, M.; Hermann, S.; Penner, A.; Wagenknecht, H.-A., Photocatalytic nucleophilic addition of alcohols to styrenes in Markovnikov and anti-Markovnikov orientation. Beilstein J. Org. Chem. 2015, 11, 568-575; (b) Yasuharu, Y.; Michiya, H.; Tatsuya, I.; Minoru, H., Photochemical Polar Addition of 1,1-Diphenylethene Using Photosensitive Surfactant in Stable Oil-in-Water Emulsion. Chem. Lett. 2004, 33 (9), 1196-1197; (c) Arnold, D. R.; Maroulis, A. J., Radical ions in photochemistry. 4. The 1,1-diphenylethylene anion radical by photosensitization (electron transfer). J. Am. Chem. Soc. 1977, 99 (22), 7355-7356.

[11] (a) Mayr, H.; Schneider, R.; Irrgang, B.; Schade, C., Kinetics of the reactions of the p-methoxy-substituted benzhydryl cation with various alkenes and 1,3-dienes. J. Am. Chem. Soc. 1990, 112 (11), 4454-4459; (b) Jaramillo, P.; Fuentealba, P.; Pérez, P., Nucleophilicity scale for nand m-nucleophiles. Chem. Phys. Lett. 2006, 427 (4), 421-425.

[12] For selected examples and reviews on multi-photon excitation see: (a) Ghosh, I.; Ghosh, T.; Bardagi, J. I.; König, B., Reduction of aryl halides by consecutive visible light-induced electron transfer processes. Science 2014, 346 (6210), 725-728; (b) Ravetz, B. D.; Pun, A. B.; Churchill, E. M.; Congreve, D. N.; Rovis, T.; Campos, L. M., Photoredox catalysis using infrared light via triplet fusion upconversion. Nature 2019, 565 (7739), 343-346; (c) Giedyk, M.; Narobe, R.; Weiß, S.; Touraud, D.; Kunz, W.; König, B., Photocatalytic activation of alkyl chlorides by assembly-promoted single electron transfer in microheterogeneous solutions. Nature Catalysis 2020, 3 (1), 40-47; (d) Chatterjee, A.; König, B., Birch-Type Photoreduction of Arenes and Heteroarenes by Sensitized Electron Transfer. Angew. Chem. Int. Ed. 2019, 58 (40), 1428914294; (e) Ghosh, I.; König, B., Chromoselective Photocatalysis: Controlled Bond Activation through Light-Color Regulation of Redox Potentials. Angew. Chem. Int. Ed. 2016, 55 (27), 7676-7679; (f) Kerzig, C.; Guo, X.; Wenger, O. S., Unexpected Hydrated Electron Source for Preparative Visible-Light Driven Photoredox Catalysis. J. Am. Chem. Soc. 2019, 141 (5), 2122-2127; (g) Glaser, F.; Kerzig, C.; Wenger, O. S., Multi-Photon Excitation in Photoredox Catalysis: Concepts, Applications, Methods. Angew. Chem. Int. Ed. 2020, 59, 2-21.

[13] Connell, T. U.; Fraser, C. L.; Czyz, M. L.; Smith, Z. M.; Hayne, D. J.; Doeven, E. H.; Agugiaro, J.; Wilson, D. J. D.; Adcock, J. L.; Scully, A. D.; Gómez, D. E.; Barnett, N. W.; Polyzos, A.; Francis, P. S., The Tandem Photoredox Catalysis Mechanism of [Ir(ppy)2(dtb-bpy)]+ Enabling Access to Energy Demanding Organic Substrates. J. Am. Chem. Soc. 2019, 141 (44), 17646-17658. 
[14] MacKenzie, I. A.; Wang, L.; Onuska, N. P. R.; Williams, O. F.; Begam, K.; Moran, A. M.; Dunietz, B. D.; Nicewicz, D. A., Discovery and characterization of an acridine radical photoreductant. Nature 2020, 580 (7801), 76-80.

[15] Beatty, J. W.; Stephenson, C. R. J., Amine Functionalization via Oxidative Photoredox Catalysis: Methodology Development and Complex Molecule Synthesis. Acc. Chem. Res. 2015, 48 (5), 1474-1484.

[16] Justin P., C.; Dian-Feng, C.; Max, K.; Ryan M., P.; Chern-Hooi, L.; Garret, M., Organocatalyzed Birch Reduction Driven by Visible Light. 2020.

[17] Wayner, D. D. M.; McPhee, D. J.; Griller, D., Oxidation and reduction potentials of transient free radicals. J. Am. Chem. Soc. 1988, 110 (1), 132-137.

[18] Lewis, F. D.; Reddy, G. D.; Schneider, S.; Gahr, M., Photophysical and photochemical behavior of intramolecular styrene-amine exciplexes. J. Am. Chem. Soc. 1991, 113 (9), 3498-3506.

[19] (a) Narayanam, J. M. R.; Tucker, J. W.; Stephenson, C. R. J., Electron-Transfer Photoredox Catalysis: Development of a Tin-Free Reductive Dehalogenation Reaction. J. Am. Chem. Soc. 2009, 131 (25), 8756-8757; (b) Nakajima, K.; Miyake, Y.; Nishibayashi, Y., Synthetic Utilization of a-Aminoalkyl Radicals and Related Species in Visible Light Photoredox Catalysis. Acc. Chem. Res. 2016, 49 (9), $1946-1956$.

[20] (a) Wang, Z.; Ai, F.; Wang, Z.; Zhao, W.; Zhu, G.; Lin, Z.; Sun, J., Organocatalytic Asymmetric Synthesis of 1,1-Diarylethanes by Transfer Hydrogenation. J. Am. Chem. Soc. 2015, 137 (1), 383-389; (b) Mahajani, N. S.; Chisholm, J. D., Synthesis of 1,1'-Diarylethanes and Related Systems by Displacement of Trichloroacetimidates with Trimethylaluminum. J. Org. Chem. 2018, 83 (7), 4131-4139; (c) Moree, W. J.; Li, B.-F.; Jovic, F.; Coon, T.; Yu, J.; Gross, R. S.; Tucci, F.; Marinkovic, D.; Zamani-Kord, S.; Malany, S.; Bradbury, M. J.; Hernandez, L. M.; O’Brien, Z.; Wen, J.; Wang, H.; Hoare, S. R. J.; Petroski, R. E.; Sacaan, A.; Madan, A.; Crowe, P. D.; Beaton, G., Characterization of Novel Selective H1Antihistamines for Clinical Evaluation in the Treatment of Insomnia. J. Med. Chem. 2009, 52 (17), 5307-5310; (d) Messaoudi, S.; Hamze, A.; Provot, O.; Tréguier, B.; Rodrigo De Losada, J.; Bignon, J.; Liu, J.-M.; Wdzieczak-Bakala, J.; Thoret, S.; Dubois, J.; Brion, J.-D.; Alami, M., Discovery of Isoerianin Analogues as Promising Anticancer Agents. ChemMedChem 2011, 6 (3), 488-497; (e) Vasilopoulos, A.; Zultanski, S. L.; Stahl, S. S., Feedstocks to Pharmacophores: Cu-Catalyzed Oxidative Arylation of Inexpensive Alkylarenes Enabling Direct Access to Diarylalkanes. J. Am. Chem. Soc. 2017, 139 (23), 7705-7708; (f) Peng, L.; Li, Y.; Li, Y.; Wang, W.; Pang, H.; Yin, G., Ligand-Controlled NickelCatalyzed Reductive Relay Cross-Coupling of Alkyl Bromides and Aryl Bromides. ACS Catal. 2018, 8 (1), 310-313.

[21] Cheltsov, A. V.; Aoyagi, M.; Aleshin, A.; Yu, E. C.-W.; Gilliland, T.; Zhai, D.; Bobkov, A. A.; Reed, J. C.; Liddington, R. C.; Abagyan, R., Vaccinia Virus Virulence Factor N1L is a Novel Promising Target for Antiviral Therapeutic Intervention. J. Med. Chem. 2010, 53 (10), $3899-$ 3906.

[22] (a) Hammond, G. S.; Saltiel, J., Photosensitized Cis-Trans Isomerization of the Stilbenes. J. Am. Chem. Soc. 1962, 84 (24), 4983-4984; (b) Singh, K.; Staig, S. J.; Weaver, J. D., Facile Synthesis of Z-Alkenes via Uphill Catalysis. J. Am. Chem. Soc. 2014, 136 (14), 5275-5278. [23] Ni, T.; Caldwell, R. A.; Melton, L. A., The relaxed and spectroscopic energies of olefin triplets. J. Am. Chem. Soc. 1989,111 (2), $457-464$. [24] Strieth-Kalthoff, F.; James, M. J.; Teders, M.; Pitzer, L.; Glorius, F., Energy transfer catalysis mediated by visible light: principles, applications, directions. Chem. Soc. Rev. 2018, 47 (19), 7190-7202. 


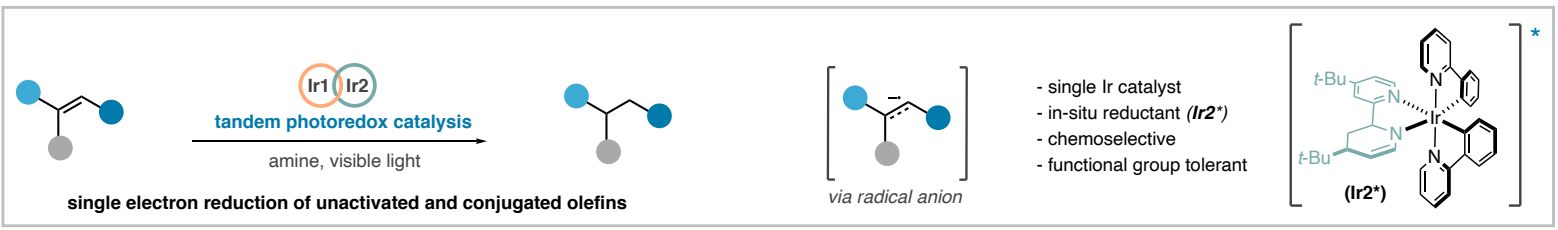




\title{
Supporting Information
}

\section{A Multiphoton Single-Electron Reduction of Olefins via Tandem Photoredox Catalysis}

Tyra H. Horngren, ${ }^{\ddagger}$ Mitchell S. Taylor, ${ }^{\dagger \ddagger}$ Milena L. Czyz, ${ }^{\dagger}$ and Anastasios Polyzos ${ }^{\dagger \S}$ *

\author{
†School of Chemistry, The University of Melbourne, Parkville 3010, Victoria, Australia \\ ${ }^{\S}$ CSIRO Manufacturing, Research Way, Clayton VIC 3168, Australia
}

${ }^{*}$ Correspondence to: anastasios.polyzos@unimelb.edu.au 


\section{Table of Contents}

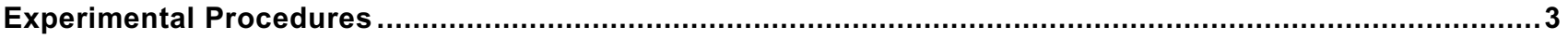

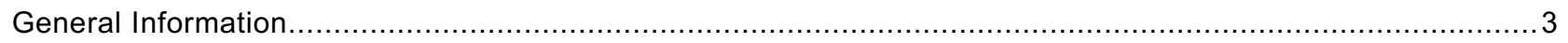

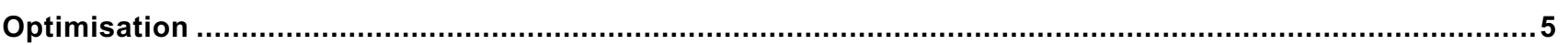

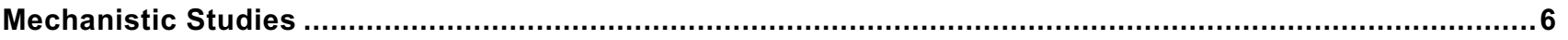

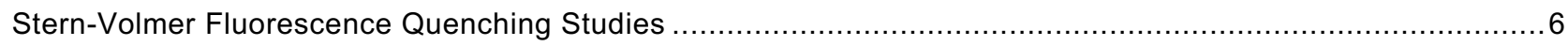

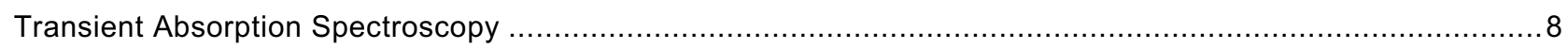

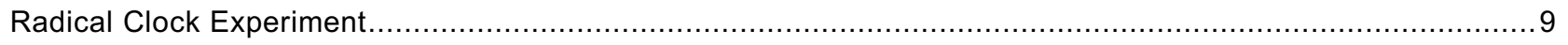

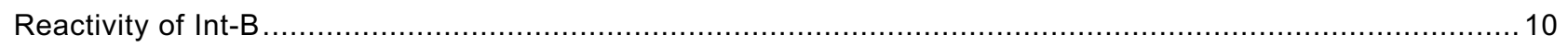

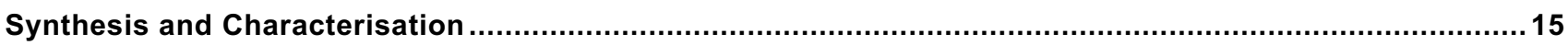

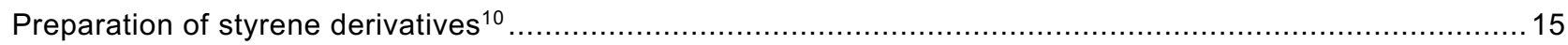

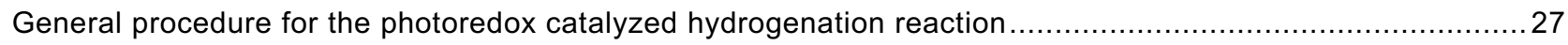

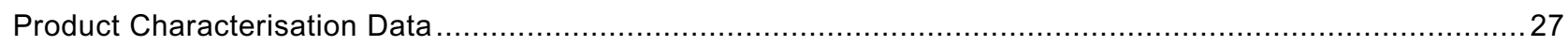

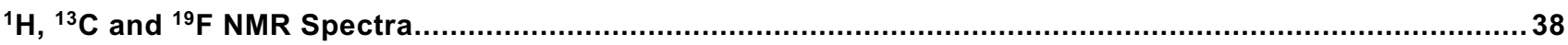

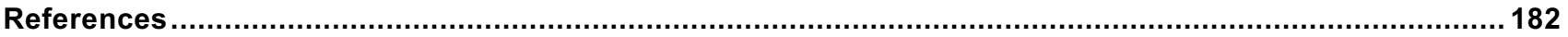




\section{Experimental Procedures}

\section{General Information}

Synthesis and General Instrumentation: Unless otherwise stated, reagents and solvents were purchased from commercial sources and used without further purification. $\left[\operatorname{Ir}(\mathrm{ppy})_{2}\right.$ (dtb-bpy)]PF 6 was prepared according to a literature procedure. ${ }^{1}$

Analytical Thin Layer Chromatography (TLC) was carried out using aluminium-backed Merck Kieselgel KG60 F254 silica plates. Preparative TLC was conducted using Analtech silica gel matrix preparative TLC plates (1.00 mm). The plates were visualized by irradiation with short-wave ultraviolet light. Flash chromatography was performed on SiliaFlash® P60 R12030B 40-63 micron silica gel.

All light promoted reactions were performed using two PR160 (40 W, 440 nm) Kessil LED lights (www.kessil.com) (Figure S1). Vials were placed on a square metal frame fitted with PC cooling fans and heat sinks for temperature control (internal temperature of reactor typically reaches $27 \pm 5{ }^{\circ} \mathrm{C}$ overnight). The power of the light source can be varied with four levels of intensity control.

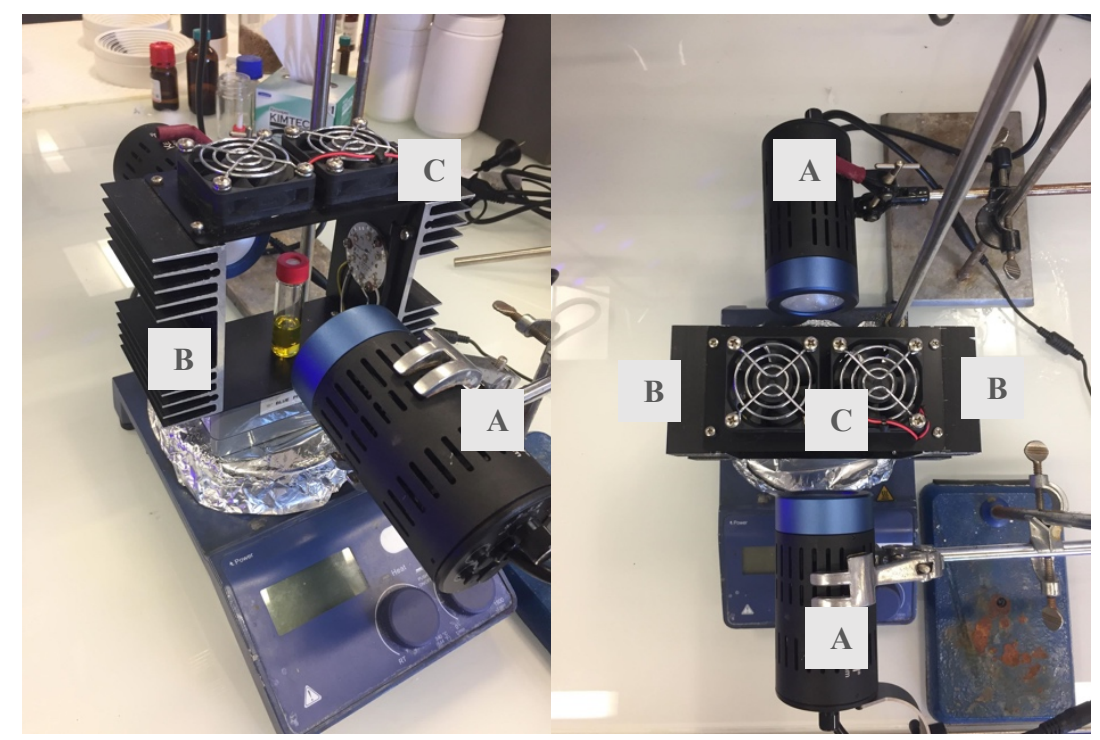

Figure S1. Photoreaction setup; a) Kessil 440 nm LED light; b) heat sinks; c) PC cooling fans.

${ }^{1} \mathrm{H}$ NMR, ${ }^{13} \mathrm{C}$ NMR and ${ }^{19} \mathrm{~F}$ NMR spectra were recorded on Varian MR-400 (400 MHz), Agilent DD2 (500 MHz) and Varian INOVA $(600 \mathrm{MHz})$. Chemical shifts are expressed in parts per million (PPM) and are referenced to the internal solvent peaks.

\section{Mass spectrometry}

High resolution mass spectrometric analyses were performed on an Agilent 1100 autosampler system coupled to an Agilent 6520 Quadrupole Time of Flight (Q-TOF) mass spectrometer controlled via MassHunter software package B.05.01. ESI solutions ( 5 ppm) were prepared in HPLC grade acetonitrile and transferred to the electrospray source by an autosampler. For each analysis, $1 \mu \mathrm{L}$ of sample was injected into the carrier solvent stream of $0.1 \%$ formic acid in $70 \%$ acetonitrile at a flow rate of $0.3 \mathrm{~mL}$ per minute. Recorded $\mathrm{m} / \mathrm{z}$ data were corrected using a reference mass by a dual-spray electrospray ionization source and using the factory-defined calibration 
pressure. Mass spectrometer conditions: drying gas flow rate, $7 \mathrm{~L} \mathrm{min-1}$; nebulizer pressure, 40 psi; drying gas temperature, $300{ }^{\circ} \mathrm{C}$; capillary voltage, $4000 \mathrm{~V}$; skimmer voltage, $65 \mathrm{~V}$; Oct Rf, $750 \mathrm{~V}$; scan range acquired, 100$1000 \mathrm{~m} / \mathrm{z}$.

\section{Transient absorption (TA) spectroscopy}

Nanosecond transient absorption measurements were performed using the $355 \mathrm{~nm}$ output from a nanosecond optical parametric oscillator (Eskpla NT340) as the excitation source (pump) $(\sim 5 \mathrm{~ns}$ pulses at $10 \mathrm{~Hz}$ ). A Xenon lamp (ILC Cermax) was used as probe with a monochromator (Acton SpectraPro 300i), a long-pass filter (370 nm), photomultiplier tube (Hamamatsu R928), and digital oscilloscope (Teledyne/LeCroy WaveSurfer 10). The wavelengths detected were $380 \mathrm{~nm}$ and $540 \mathrm{~nm}$.

\section{Fluorescent quenching experiments}

Steady-state luminescent spectra were recorded using an Agilent Cary Eclipse Fluorescence Spectrophotometer. Samples were excited at $440 \mathrm{~nm}$, slit widths were $5 \mathrm{~nm}$ and the area under the spectra were used for determining the Stern-Volmer quenching values. 


\section{Optimisation}

Table S1: Reaction optimisation
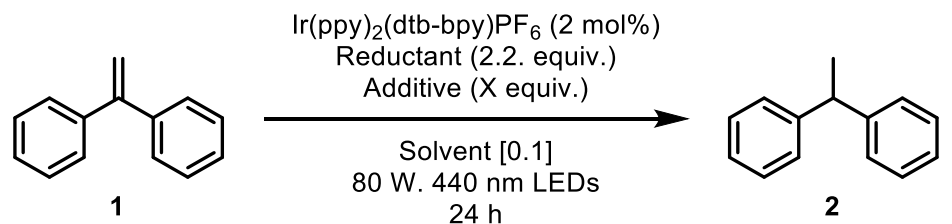

\begin{tabular}{|c|c|c|c|c|}
\hline Solvent & Reductant & $\begin{array}{c}\text { Additive } \\
\text { (equiv.) }\end{array}$ & $\begin{array}{c}\text { Conversion } \\
{[\%]^{\mathrm{a}}}\end{array}$ & $\begin{array}{c}\text { Yield of } 2 \\
{[\%]^{a}}\end{array}$ \\
\hline DMF & Triethylamine & & 90 & 3 \\
\hline $\mathrm{MeCN}$ & Triethylamine & & 100 & 4 \\
\hline DMSO & Triethylamine & & 100 & 2 \\
\hline $\mathrm{MeOH}$ & Triethylamine & & 92 & 14 \\
\hline $\mathrm{EtOH}$ & Triethylamine & & 99 & 7 \\
\hline Toluene & Triethylamine & & 100 & 0 \\
\hline THF & Triethylamine & & 96 & 0 \\
\hline $\mathrm{MeOH}$ & Tributylamine & & 100 & 6 \\
\hline $\mathrm{MeOH}$ & 1,2,2,6,6-Pentamethylpiperidine & & 100 & 7 \\
\hline $\mathrm{MeOH}$ & $N, N$-Diisopropylethylamine & & 100 & 37 \\
\hline $\mathrm{MeOH}$ & Tetrahydroisoquinoline & & 18 & 8 \\
\hline $\mathrm{MeOH}$ & Tetramethylethylenediamine & & 47 & 11 \\
\hline $\mathrm{MeOH}$ & $N, N$-Dicyclohexylmethylamine & & 92 & 20 \\
\hline $\begin{array}{c}\mathrm{MeOH} / \mathrm{H}_{2} \mathrm{O} \\
(9: 1)\end{array}$ & $N, N$-Diisopropylethylamine & & 98 & 55 \\
\hline $\begin{array}{c}\mathrm{MeOH} / \mathrm{H}_{2} \mathrm{O} \\
(8: 2)\end{array}$ & $\mathrm{N}, \mathrm{N}$-Diisopropylethylamine & & 90 & $29^{b}$ \\
\hline $\begin{array}{c}\mathrm{MeOH} / \mathrm{H}_{2} \mathrm{O} \\
(9: 1)\end{array}$ & $N, N$-Diisopropylethylamine & $\begin{array}{c}\mathrm{HCOOH} \\
(2.5)\end{array}$ & 100 & 74 \\
\hline $\begin{array}{c}\mathrm{MeOH} / \mathrm{H}_{2} \mathrm{O} \\
(9: 1)\end{array}$ & $N, N$-Diisopropylethylamine & $\begin{array}{c}\mathrm{HCOOH} \\
(2.8)\end{array}$ & 100 & 82 \\
\hline $\begin{array}{c}\mathrm{MeOH} / \mathrm{H}_{2} \mathrm{O} \\
(9: 1)\end{array}$ & $N, N$-Diisopropylethylamine & $\begin{array}{c}\mathrm{HCOOH} \\
(3.0)\end{array}$ & 100 & 79 \\
\hline
\end{tabular}

ayield determined by ${ }^{1} \mathrm{H}$ NMR spectroscopy using sulfolene as an internal standard. ${ }^{\mathrm{b}}$-amino adduct 3 was the major by-product.<smiles>CC(C)N(C(C)C)C(C)CC(c1ccccc1)c1ccccc1</smiles> 


\section{Mechanistic Studies}

\section{Stern-Volmer Fluorescence Quenching Studies}

\section{$\underline{\text { Quenching of } \operatorname{Ir} 1^{*}}$}

A standard solution of $\left[\operatorname{Ir}(\mathrm{ppy})_{2}\right.$ (dtb-bpy)]PF${ }_{6}$ in methanol $(0.1 \mathrm{mM})$ was prepared in a $10 \mathrm{~mL}$ volumetric flask. An aliquot $(2 \mathrm{~mL})$ was transferred to a septum capped quartz cuvette. A solution containing an appropriate amount of quencher in methanol (1 mL) was added. The sample was sparged with $\mathrm{N}_{2}$ for 1 min prior to fluorescence measurement being taken.

A

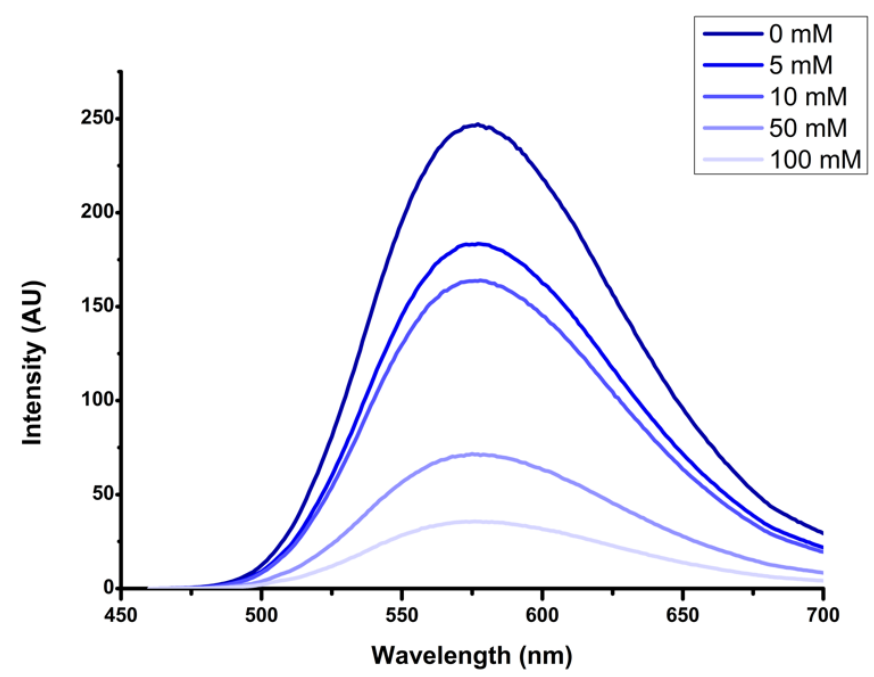

B

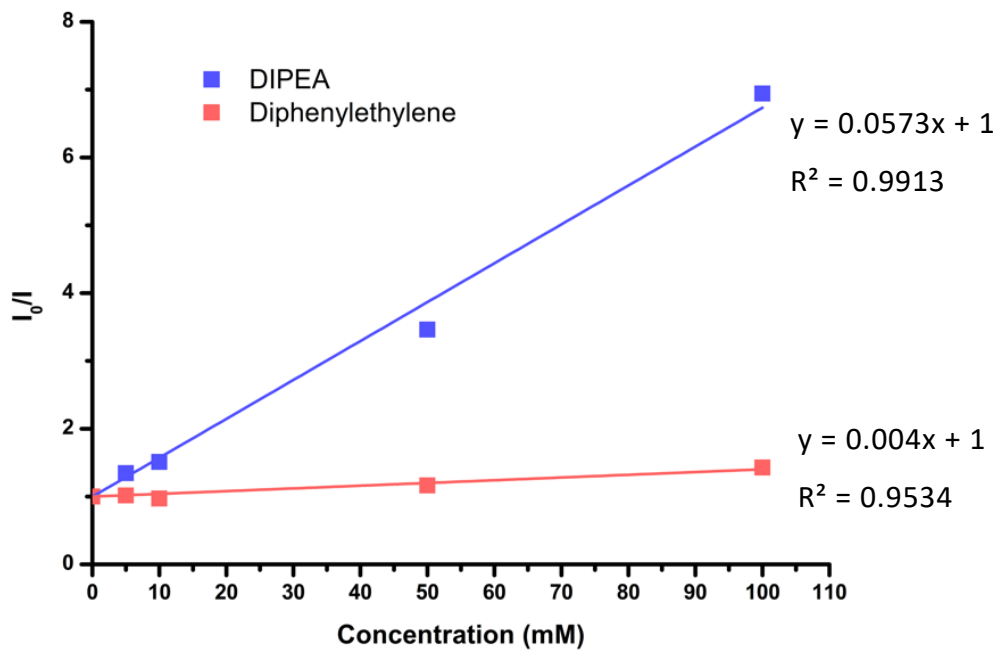

Figure S2: (A) Photoluminescence quenching of $(\operatorname{Ir} 1)^{*}$ in methanol by DIPEA. (B) Stern-Volmer plot of fluorescence intensity of $(\operatorname{Ir} 1)^{*}$ in the presence of DIPEA (blue) and diphenylethylene (red). 


\section{Quenching of Ir2*:}

\section{Emission from Ir2* in the absence of the quencher:}

A standard solution containing DIPEA $(50 \mathrm{mM})$ and $\left[\operatorname{lr}(\mathrm{ppy})_{2}(\mathrm{dtb}-\mathrm{bpy})\right] \mathrm{PF}_{6}(0.1 \mathrm{mM})$ in methanol was prepared in a $10 \mathrm{~mL}$ volumetric flask. An aliquot $(3 \mathrm{~mL})$ was transferred to a septum capped quartz cuvette, degassed for $1 \mathrm{~min}$ with $\mathrm{N}_{2}$ and irradiated for $10 \mathrm{~min}$ with $15 \mathrm{~W}, 448 \mathrm{~nm}$ blue LED light, under a positive pressure of $\mathrm{N}_{2}$. Fluorescence measurement was taken immediately after the sample was removed from the blue LED reactor.

\section{Quenching studies:}

Neat diphenylethylene was added, in $2 \mu \mathrm{L}$ increments, to the quartz cuvette via an air-tight microsyringe. Following each incremental addition, the sample was sparged with $\mathrm{N}_{2}$ for 1 minute and irradiated with $15 \mathrm{~W}, 448 \mathrm{~nm}$ blue LED light under a positive pressure of $\mathrm{N}_{2}$ for 10 minutes. Each time the fluorescence measurement was taken immediately after the sample was removed from the blue LED reactor.

A

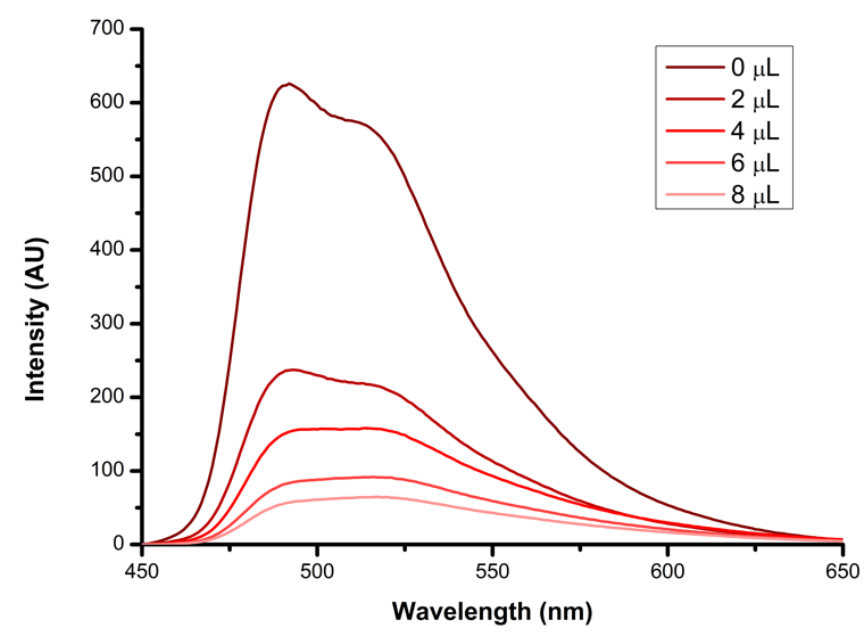

B

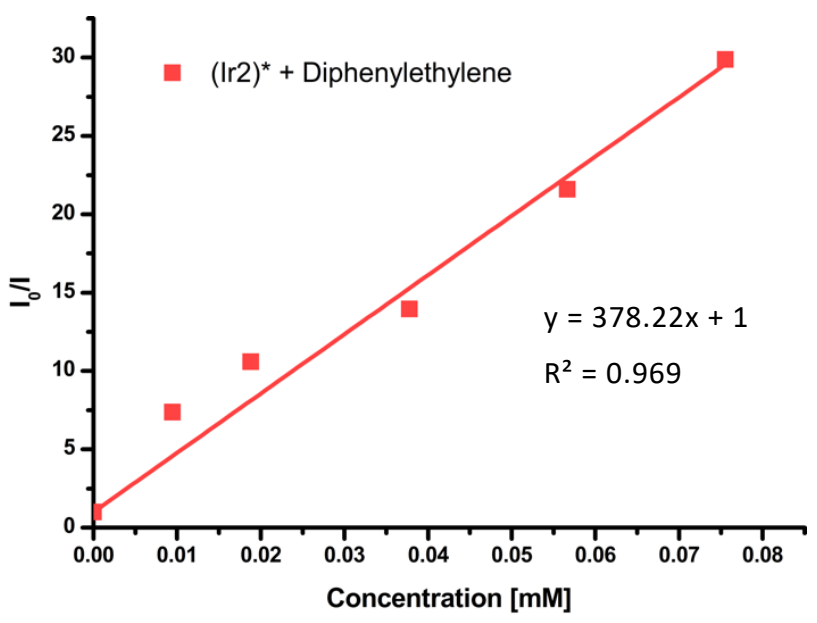

Figure S3: (A) Photoluminescence quenching of (Ir2)* by diphenylethylene. (B) Stern-Volmer plot of fluorescence intensity in the presence of diphenylethylene. 


\section{Transient Absorption Spectroscopy}

Samples for transient-absorption studies were prepared in the following manner:

A standard solution containing DIPEA $(50 \mathrm{mM})$ and $\left[\operatorname{lr}(\mathrm{ppy})_{2}(\mathrm{dtb}-\mathrm{bpy})\right] \mathrm{PF}_{6}(0.1 \mathrm{mM})$ in methanol was prepared in a $10 \mathrm{~mL}$ volumetric flask. An aliquot $(3 \mathrm{~mL})$ was transferred to a septum capped quartz cuvette. Neat diphenylethylene $(53 \mu \mathrm{L})$ was added to the cuvette via an air-tight microsyringe, and the sample was sparged with nitrogen for 1 minute, and irradiated with $15 \mathrm{~W}, 448 \mathrm{~nm}$ blue LED light under a positive pressure of $\mathrm{N}_{2}$ for 10 minutes. The transient absorption measurement was then recorded immediately after the sample was removed from the blue LED reactor.

A

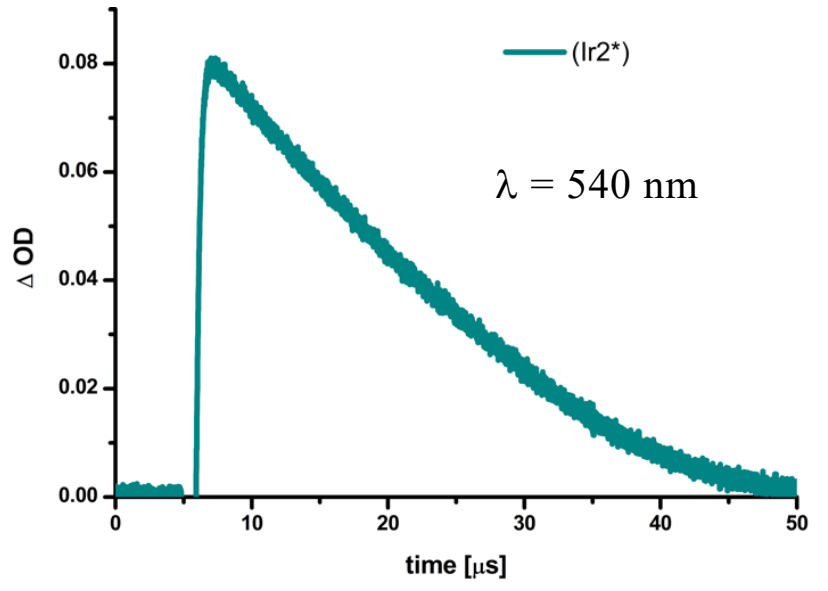

C

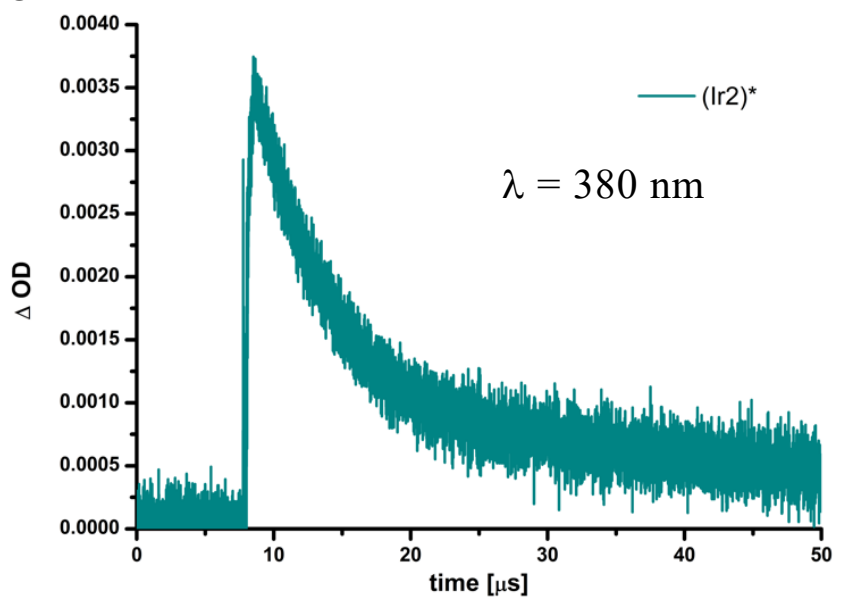

B

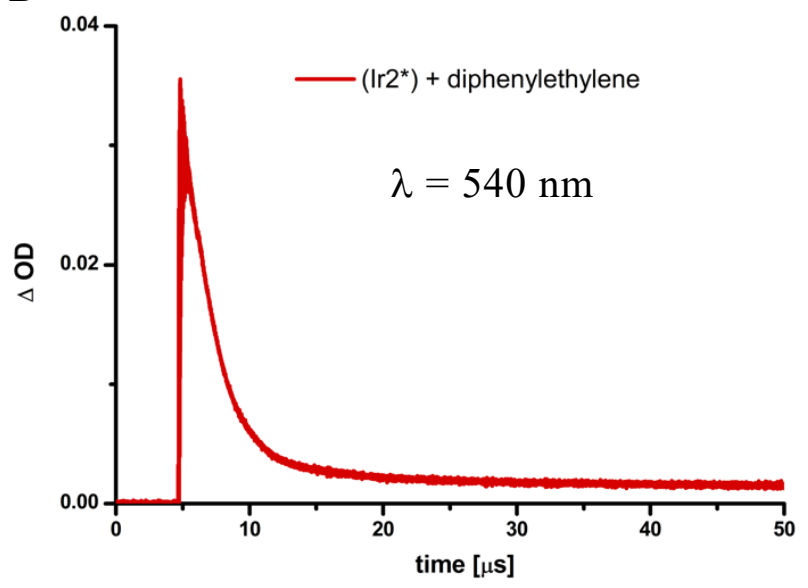

D

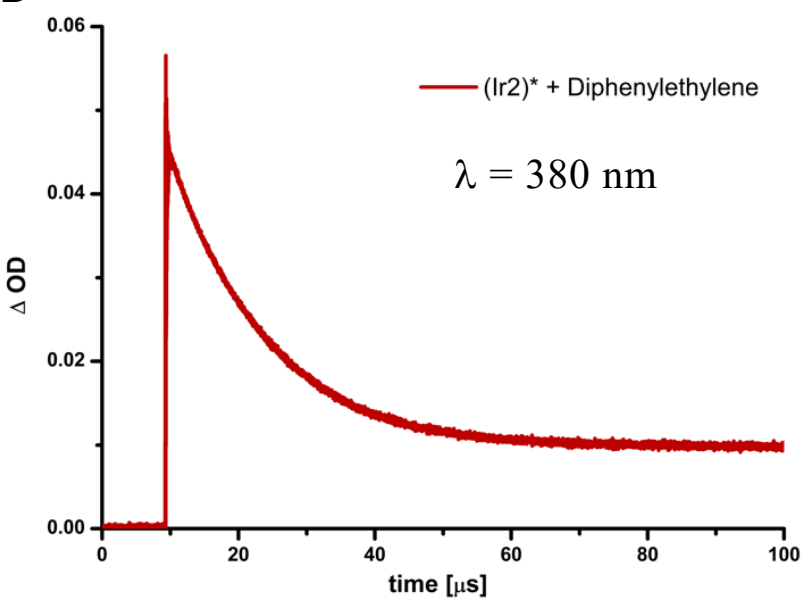

Figure S4: (A) Transient absorption decay profile of $(\operatorname{Ir} 2)^{*}$ following excitation at $\lambda_{\mathrm{ex}}=355 \mathrm{~nm}$, probe $=540 \mathrm{~nm}(\mathrm{~B})$ Transient absorption decay profile of $(\mathrm{Ir} 2)^{*}$ following excitation at $\lambda_{\mathrm{ex}}=355 \mathrm{~nm}$, probe $=540 \mathrm{~nm}$ in the presence of diphenylethylene (100 mM). C) Transient absorption decay profile of (Ir2)* following excitation at $\lambda_{e x}=355 \mathrm{~nm}$, probe $=380 \mathrm{~nm}$ (D) Transient absorption decay profile of (Ir2)* following excitation at $\lambda_{\mathrm{ex}}=355 \mathrm{~nm}$, probe $=380$ $\mathrm{nm}$ in the presence of diphenylethylene $(100 \mathrm{mM})$. 


\section{Radical Clock Experiment}

In polar solvents, a radical anion derived from diarylethylene (Int-A) is quenched by a proton donor resulting in a formation of a neutral radical at the more stabilized benzylic position (Int-B). ${ }^{2}$ To enable detection of Int-B in our reaction, we subjected (1-cyclopropylvinyl)benzene (39) to the optimized photoredox hydrogenation protocol. The tertiary benzylic radical Int-B39 has been reported to undergo a relatively slow $\left(\mathrm{k} \approx 4 \times 10^{5} \mathrm{~s}^{-1}\right)^{3}$ ring opening rearrangement resulting in the formation of open chained product $\mathbf{4 0}$. Thus, it was hypothesized that there should be competition between formation of $\mathbf{4 0}$ and $\mathbf{4 1}$ if Int-B39 is an intermediate along the main reaction pathway.

As shown in Figure 5 below, rearranged open-chain olefin 40, the reduced unrearranged 41 as well as and the Markovnikov methanol adduct 42 were detected in the ${ }^{1} \mathrm{H}$ NMR spectrum of the crude reaction mixture (Figure S5 below), in the ratio of approx. $40: 41: 42=1: 1.6: 0.4$. All three products derive from Int-B39. Oxidation of the benzylic radicals to a carbocations, followed by a nucleophilic attack by solvent is known, ${ }^{2,4}$ and yet it is a minor product here despite high nucleophilicity of the $\mathrm{C}-\mathrm{C}$ bond in the cyclopropane ring.

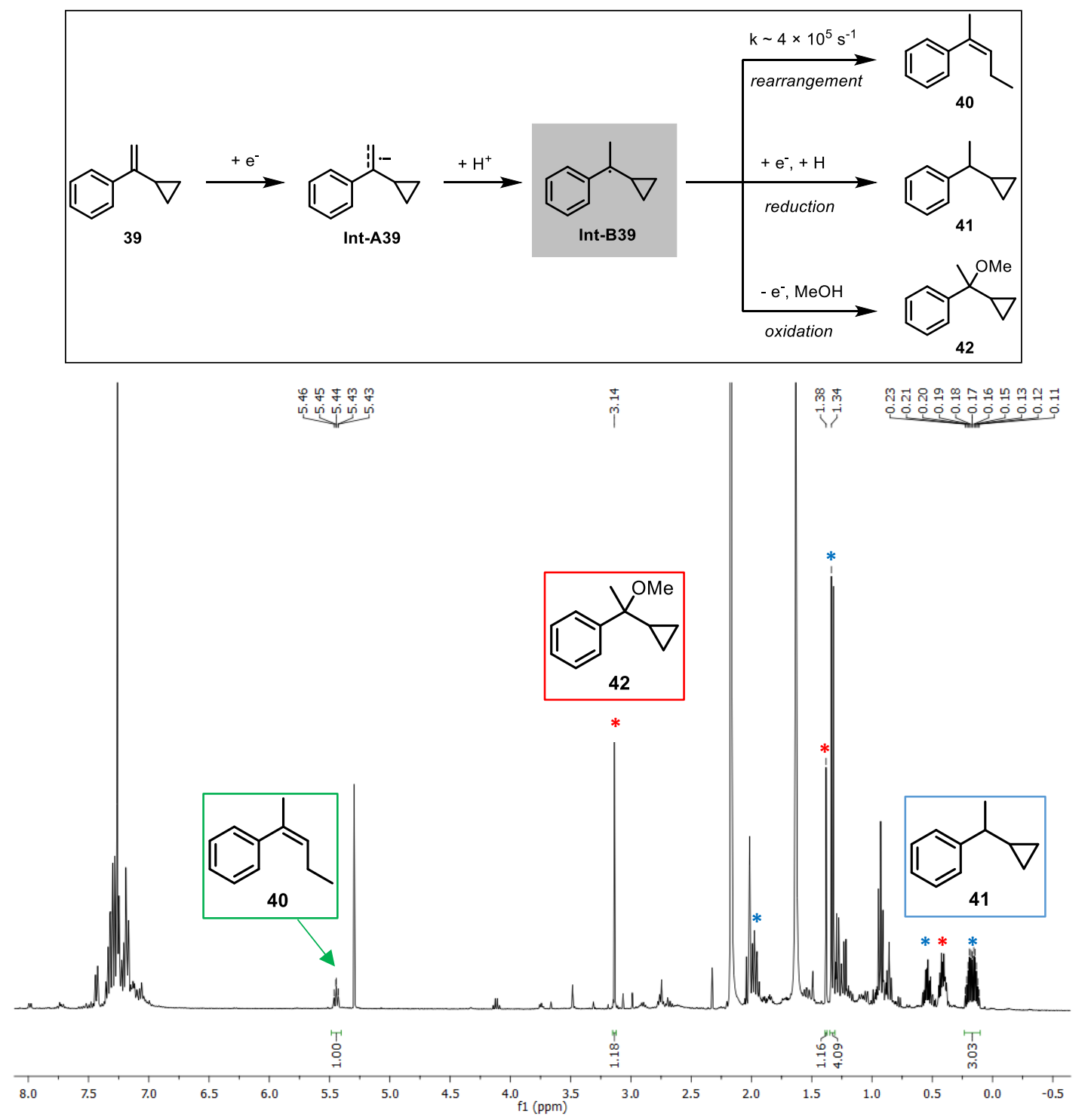

Figure S5: Top: formation of 40, 41 and 42 from Int-B39. Bottom: ${ }^{1} \mathrm{H}$ NMR spectrum of the crude reaction mixture. $40,{ }^{5} 41^{6}$ and $42^{7}$ are known compounds and the chemical shifts match those reported in the literature. 


\section{Reactivity of Int-B}

To determine how Int-B converts into fully hydrogenated product, we conducted deuterium labelling experiments using substrate 16a. Two plausible pathways were identified. Path $A$ involves a hydrogen atom transfer from the DIPEA radical cation, a mechanism previously reported for transfer hydrogenation of ketimines under similar reaction conditions. ${ }^{8}$ In path $B$, a second electron transfer step generates an anionic Int-C, which is quenched by protic solvent or formic acid.

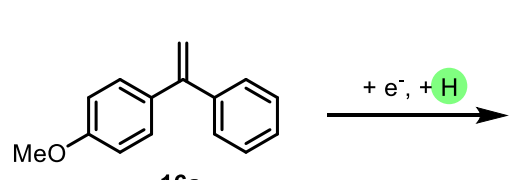

$16 a$

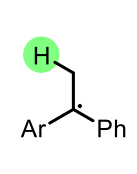

Int-B16

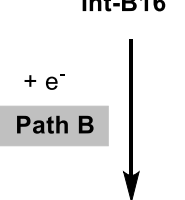

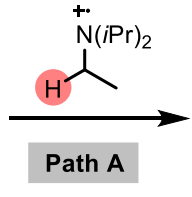

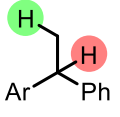

16

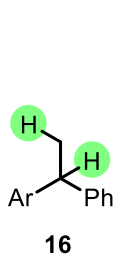

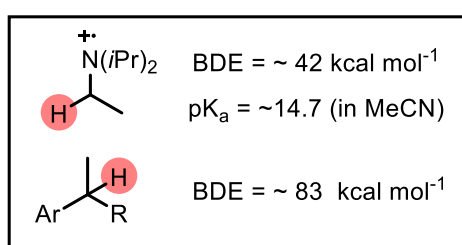

\begin{tabular}{|cl}
\hline $\mathrm{H}-\mathrm{OH}$ & $\mathrm{pK}_{\mathrm{a}}=15.7$ \\
$\mathrm{H}-\mathrm{OMe}$ & $\mathrm{pK}_{\mathrm{a}}=15.5\left(\right.$ in $\left.\mathrm{H}_{2} \mathrm{O}\right)$ \\
$\mathrm{H} \mathrm{O}_{\mathrm{H}}$ & $\mathrm{pK}_{\mathrm{a}}=3.75\left(\right.$ in $\left.\mathrm{H}_{2} \mathrm{O}\right)$ \\
\hline
\end{tabular}

Figure S6: Path A: formation of product 16 through direct hydrogen atom transfer from the radical cation of DIPEA; Path B: formation of product 16 through consecutive single electron transfer and protonation.

Replacing DIPEA with $\mathrm{d}_{15}-\mathrm{NEt}_{3}$ was not informative, as only traces of the reduced product could be detected in the ${ }^{1} \mathrm{H}$ NMR spectrum of the crude reaction mixture. Consequently, $\mathrm{d}_{4}-\mathrm{MeOH}, \mathrm{D}_{2} \mathrm{O}$ and $\mathrm{HCO}_{2} \mathrm{D}$ were used as solvents with DIPEA as the reductive quencher. Mass spectrometry of the crude reaction mixture revealed that both monodeuterated products, 43 and/or $44(\mathrm{~m} / \mathrm{z}=214.12)$ and bis-deuterated product $45(\mathrm{~m} / \mathrm{z}=215.13)$ were generated under these reaction conditions. Reduced product 16 with no deuterium incorporation was not detected in the ${ }^{1} \mathrm{H}$ NMR spectrum of the crude reaction mixture.

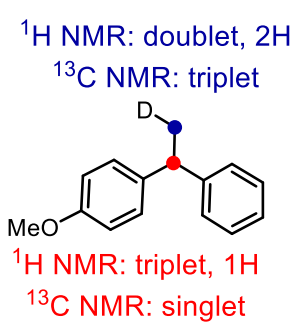

43

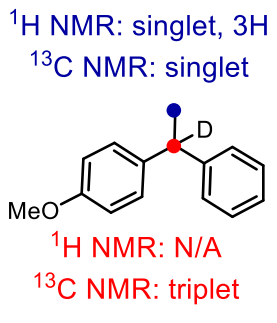

44

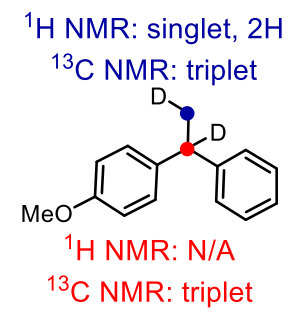

45

HRMS (ESI) m/z calc. for $\mathrm{C}_{15} \mathrm{H}_{16} \mathrm{DO}$ $[\mathrm{M}+\mathrm{H}]^{+} 214.1342$ found 214.1217

HRMS (ESI) $\mathrm{m} / \mathrm{z}$ calc. for $\mathrm{C}_{15} \mathrm{H}_{15} \mathrm{D}_{2} \mathrm{O}$ $[\mathrm{M}+\mathrm{H}]^{+} 215.1405$ found 215.1253

Figure $\mathbf{S 7}$ Three possible deuterated products detected in the mass spectrum of the crude reaction mixture and their ${ }^{1} \mathrm{H}$ NMR and ${ }^{13} \mathrm{C}$ NMR splitting patterns. ${ }^{9}$ 


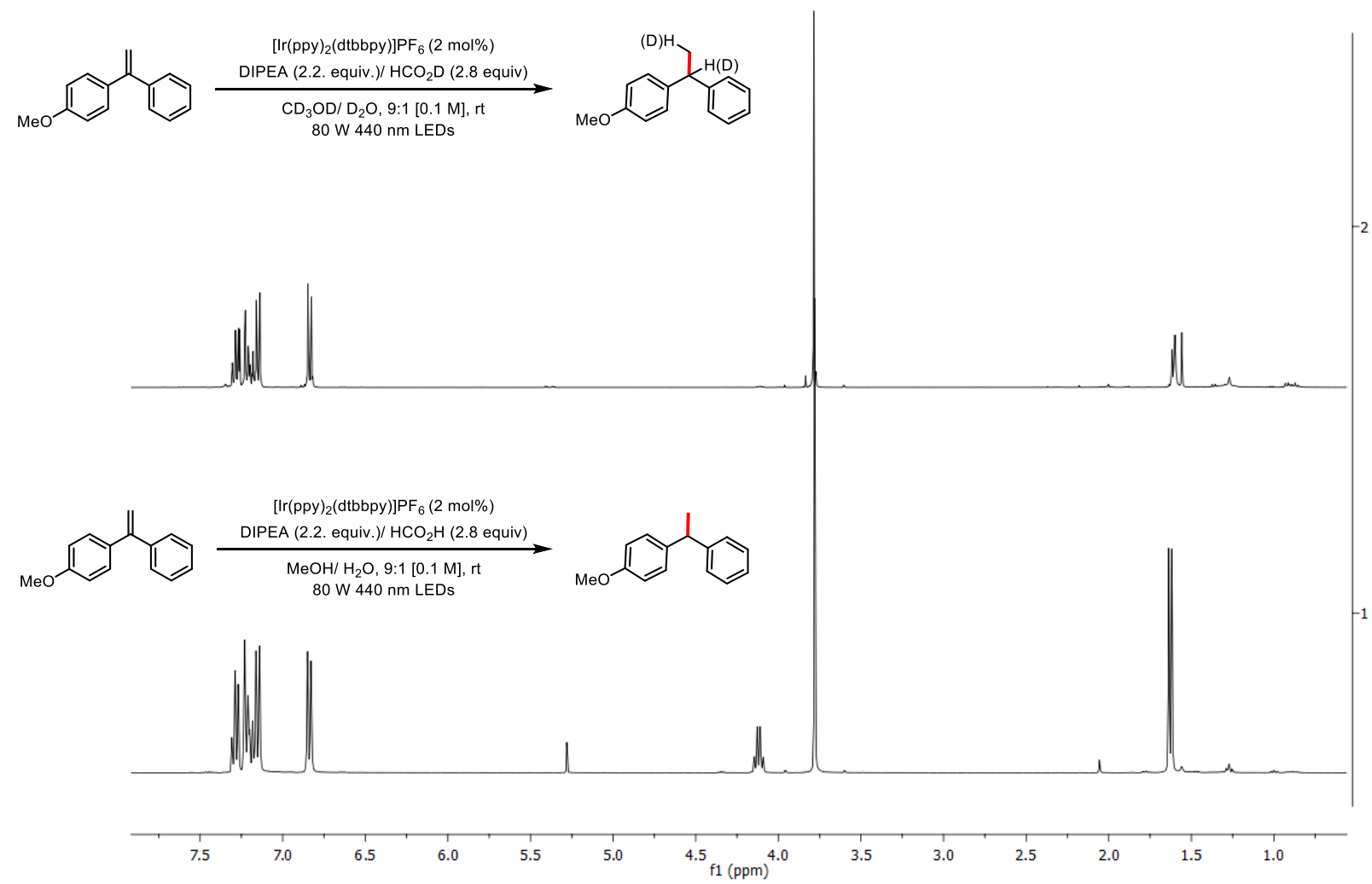

Figure S8: Comparison of the ${ }^{1} \mathrm{H}$ NMR spectrum $\left(\mathrm{CDCl}_{3}, 400 \mathrm{MHz}\right)$ of the reduced product run in non-deuterated solvents (bottom) and deuterated solvents (top).
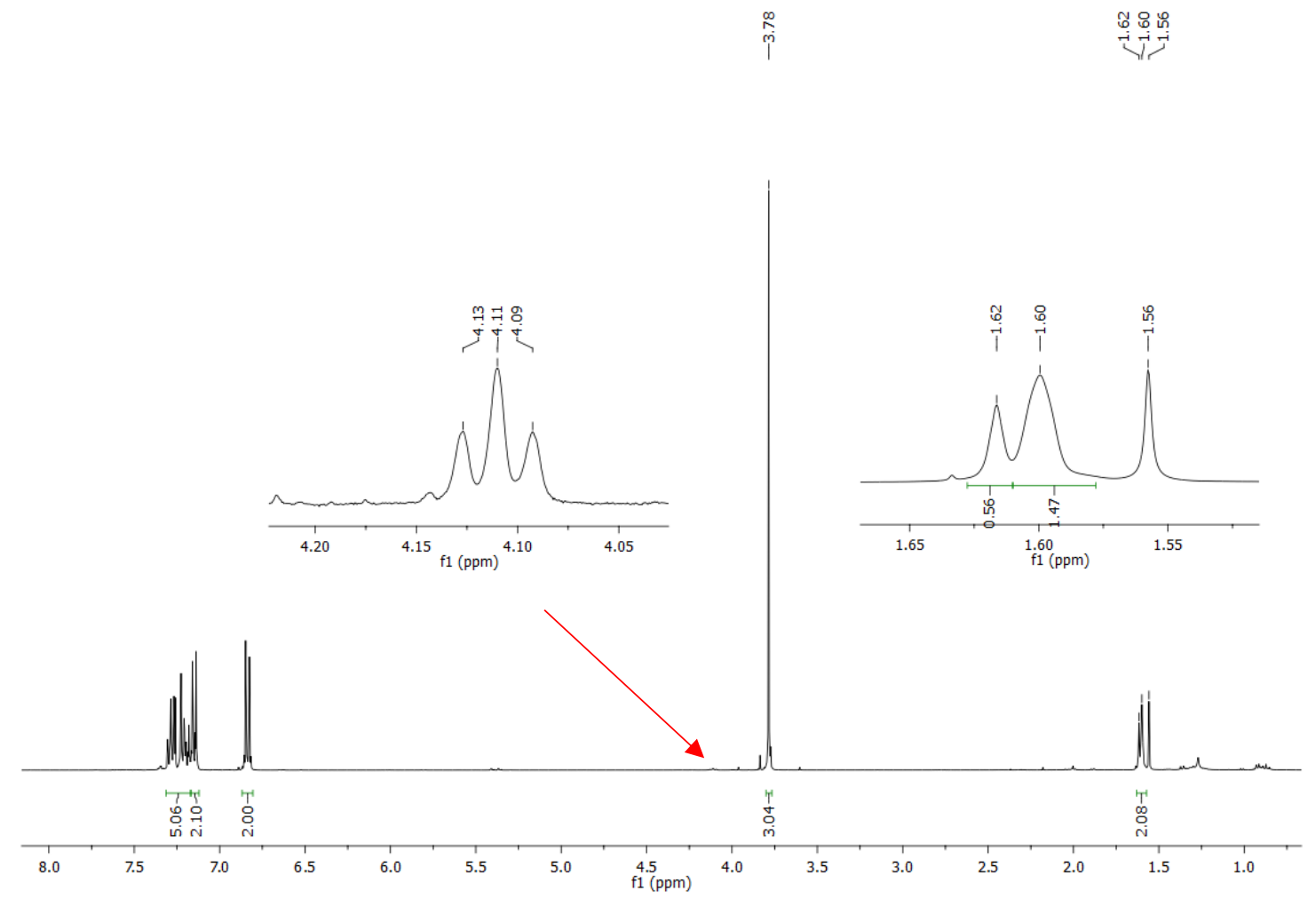

Figure S9: ${ }^{1} \mathrm{H}$ NMR spectrum $\left(\mathrm{CDCl}_{3}, 500 \mathrm{MHz}\right)$ of hydrogenation reaction of substrate 16a run in deuterated solvents 
${ }^{1} \mathrm{H}$ NMR Spectroscopic analysis revealed a baseline triplet at $4.11 \mathrm{ppm}$ (Figure S9), suggesting that compound 43 formed in trace quantities. This indicated that resonances at $1.62 \mathrm{ppm}$ and $1.60 \mathrm{ppm}$, are both singlets corresponding to products 44 and $45 .{ }^{13} \mathrm{C}$ NMR spectrum (Figure S10) confirmed that resonances at $44.5 \mathrm{ppm}$ and $22.2 \mathrm{ppm}$ both split into a singlet and a triplet, confirming incomplete deuterium incorporation at both distal and proximal positions.

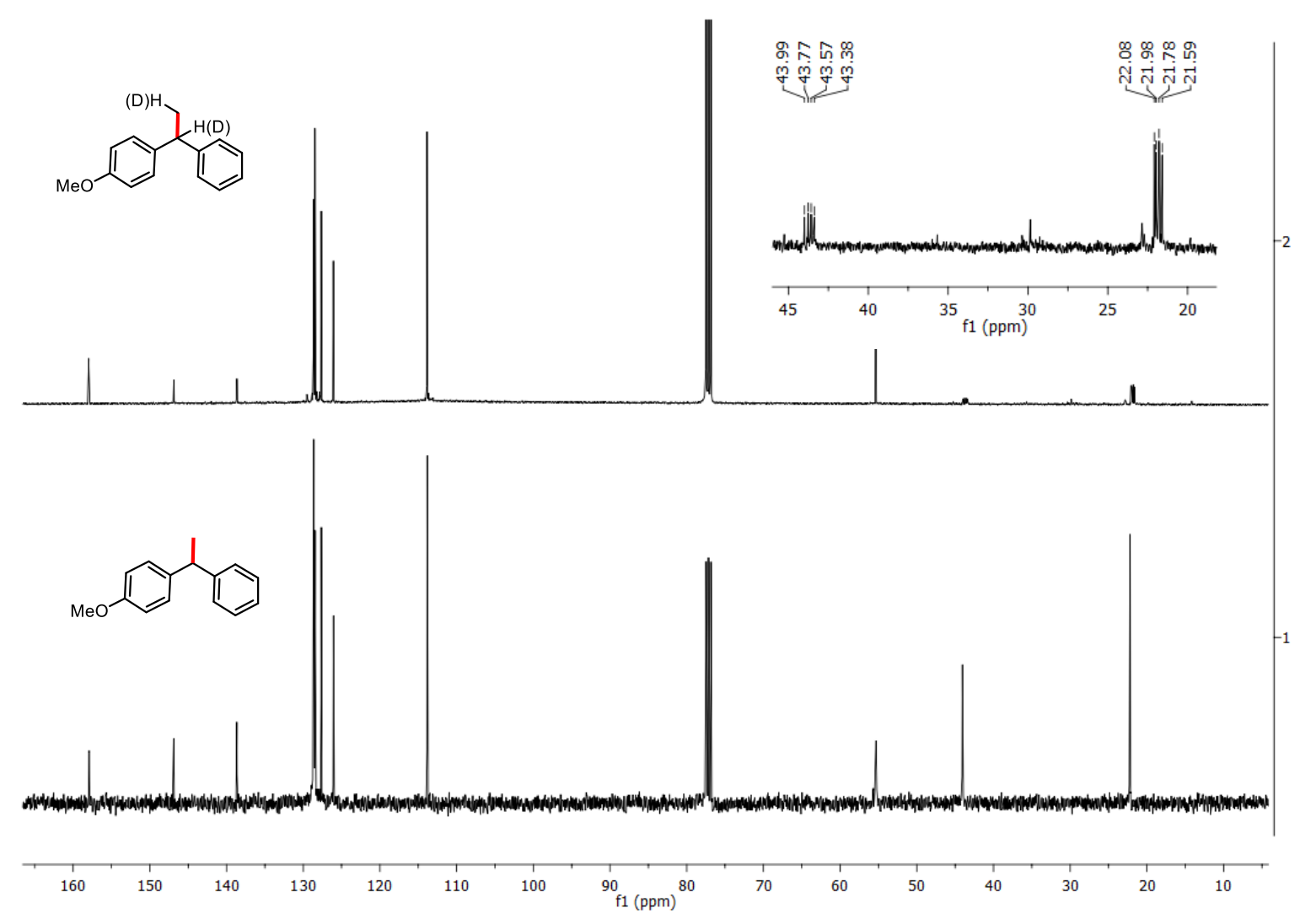

Figure S10: Comparison of the ${ }^{13} \mathrm{C}$ NMR spectra $\left(\mathrm{CDCl}_{3}, 100 \mathrm{MHz}\right)$ of the reduced product run in non-deuterated solvents (bottom) and deuterated solvents (top).

Lastly, ${ }^{1} \mathrm{H}-{ }^{13} \mathrm{C}$ HSQC experiment (Figure S11) revealed 2D correlation between the major singlet in ${ }^{1} \mathrm{H}$ NMR spectrum at $1.60 \mathrm{ppm}$ and a triplet in ${ }^{13} \mathrm{C}$ NMR spectrum at $21.8 \mathrm{ppm}$, verifying that bis-deuterated product 45 is the major product from this reaction. The integration ratio pf approx. $1.47: 0.56$ would roughly correspond to $64 \%$ bis-deuteration product.

Formation of compound $\mathbf{4 4}$ can be rationalized by the DIPEA radical cation acting as a source of acidic proton. It is plausible that electrostatic attraction between the radical anion of olefin and radical cation of DIPEA is driving this reactivity. 


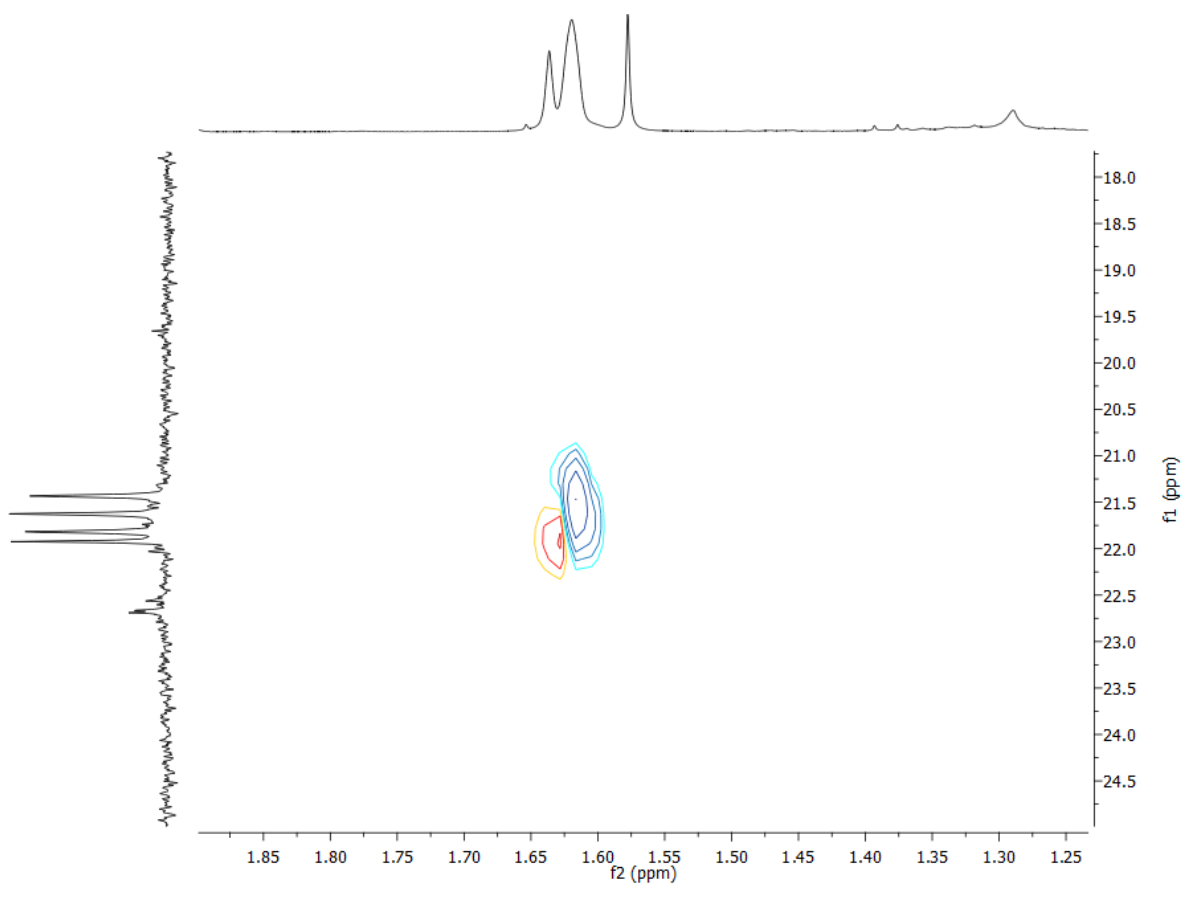

Figure S11: Partial ${ }^{1} \mathrm{H}-{ }^{13} \mathrm{C}$ HSQC spectrum demonstrating correlation between the major singlet in ${ }^{1} \mathrm{H}$ NMR and the triplet in ${ }^{13} \mathrm{C}$ NMR spectra.

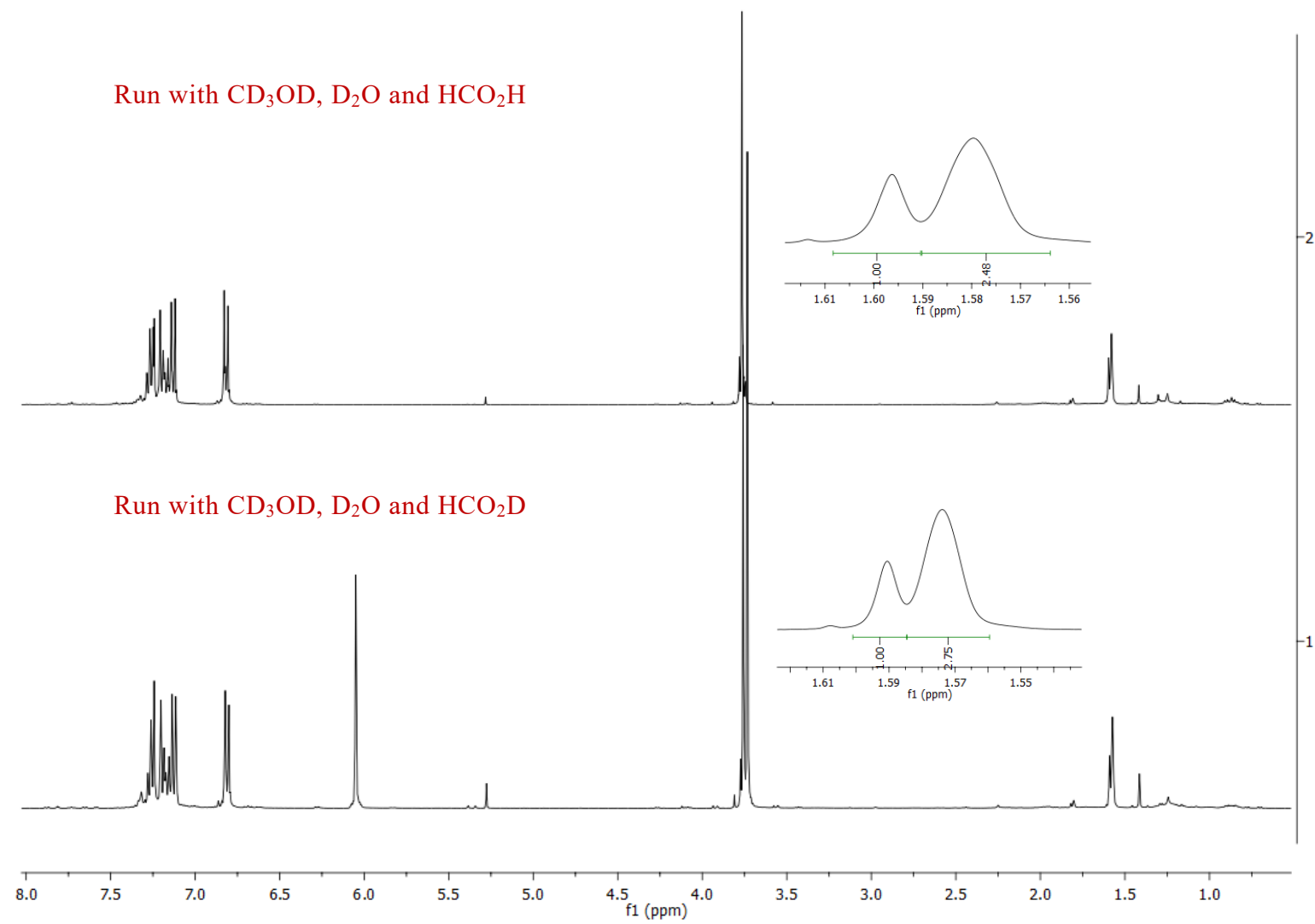

Figure S12: Comparison of ${ }^{1} \mathrm{H}$ NMR spectra of the crude reaction mixtures run with or without deuterated formic acid. The proportion of bis-deuterated product is only slightly lower without deuterated formic acid (62\% vs $65 \%$ ), suggesting formic acid is not the major protonation source. 
Run with $\mathrm{CD}_{3} \mathrm{OD}, \mathrm{H}_{2} \mathrm{O}$ and $\mathrm{HCO}_{2} \mathrm{D}$

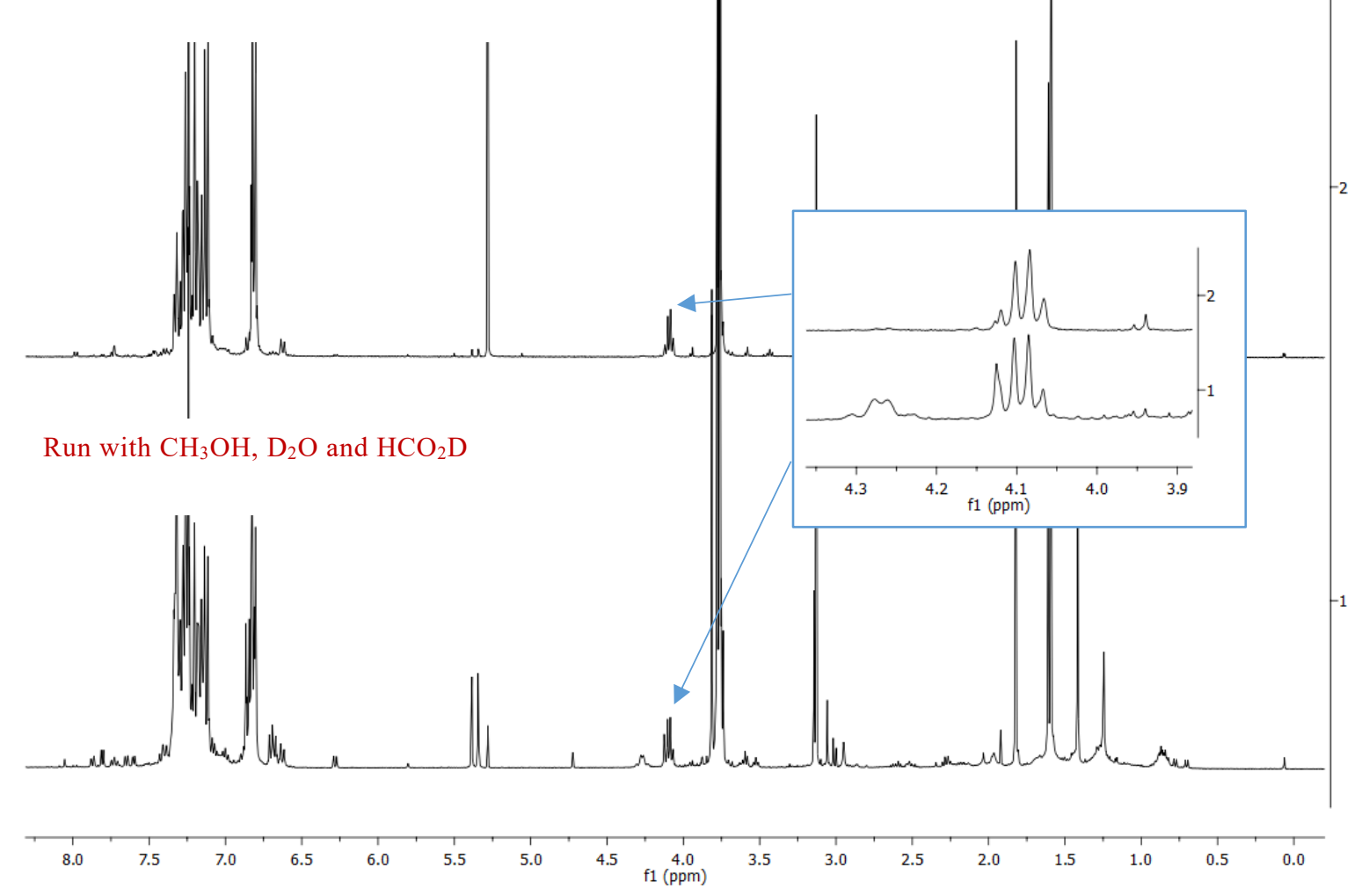

Figure S13: Comparison of ${ }^{1} \mathrm{H}$ NMR spectra of the crude reaction mixtures run with methanol and $\mathrm{D}_{2} \mathrm{O}(\mathrm{bottom})$ or with $\mathrm{CD}_{3} \mathrm{OD}$ and water (top). The characteristic quartet around $4.1 \mathrm{ppm}$ shows the presence of non-deuterated reduced product 16 , signifying that solvents are the major sources of protons in this reaction. 


\section{Synthesis and Characterisation}

\section{Preparation of styrene derivatives ${ }^{10}$}

\section{Method A:}

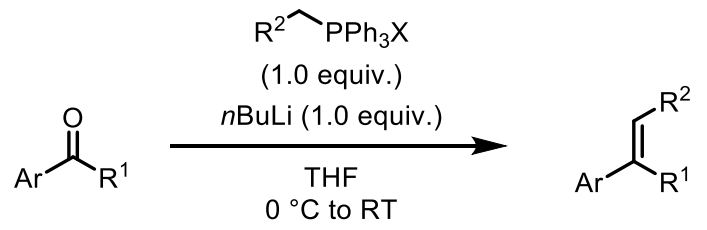

A solution of $n \mathrm{BuLi}$ in hexanes $\left(\mathrm{C}=1.6 \mathrm{M}, 4.0 \mathrm{mmol}, 1.0\right.$ equiv.) was added dropwise, at $0{ }^{\circ} \mathrm{C}$, to a solution of a Wittig salt $\left(4.0 \mathrm{mmol}, 1.0\right.$ equiv.) in dry THF $(30 \mathrm{~mL})$. The reaction mixture was stirred at $0{ }^{\circ} \mathrm{C}$ for 30 minutes. $\mathrm{A}$ solution of the carbonyl compound $\left(4.0 \mathrm{mmol}, 1.0\right.$ equiv.) in dry THF $(10 \mathrm{~mL})$ was added dropwise at $0{ }^{\circ} \mathrm{C}$, and the reaction mixture was stirred at room temperature overnight. It was then diluted with brine and extracted with EtOAc $(3 \times 40 \mathrm{~mL})$. The combined organic extracts were washed with brine $(3 \times)$ and dried with $\mathrm{MgSO}_{4}$. The solvent was removed under reduced pressure and the residue was purified by flash chromatography on silica eluting with 1 $5 \% \mathrm{EtOAc/nhexane} \mathrm{to} \mathrm{yield} \mathrm{the} \mathrm{desired} \mathrm{product.}$

\section{Substrates synthesized using method A:}<smiles>C=C(c1ccccc1)c1ccc(F)cc1</smiles>

1-Fluoro-4-(1-phenylvinyl)benzene (4a): prepared with methyltriphenylphosphonium bromide; flash chromatography eluting with $5 \%$ EtOAc/nhexane afforded the desired product as a colourless liquid $(0.57 \mathrm{~g}, 72 \%$ yield).

${ }^{1} \mathrm{H} \mathrm{NMR}\left(\mathrm{CDCl}_{3}, 400 \mathrm{MHz}\right): \delta=7.39-7.31(\mathrm{~m}, 7 \mathrm{H}), 7.07-7.01(\mathrm{~m}, 2 \mathrm{H}), 5.46(\mathrm{~d}, J=1.1 \mathrm{~Hz}, 1 \mathrm{H}), 5.44(\mathrm{~d}, J=1.1 \mathrm{~Hz}$, $1 \mathrm{H})$.

${ }^{13} \mathrm{C} \mathrm{NMR}\left(\mathrm{CDCl}_{3}, 100 \mathrm{MHz}\right): \delta=162.7\left(\mathrm{~d}, J_{\mathrm{C}-\mathrm{F}}=245.4 \mathrm{~Hz}\right), 149.2,141.4,137.7\left(\mathrm{~d}, J_{\mathrm{C}-\mathrm{F}}=3.0 \mathrm{~Hz}\right), 130.0\left(\mathrm{~d}, J_{\mathrm{C}-\mathrm{F}}=\right.$ $7.90 \mathrm{~Hz}), 128.4,128.3,128.0,115.3\left(\mathrm{~d}, J_{\mathrm{C}-\mathrm{F}}=21.4 \mathrm{~Hz}\right), 114.4$.

${ }^{19} \mathrm{~F} \mathrm{NMR}\left(376 \mathrm{MHz}, \mathrm{CDCl}_{3}\right): \delta=-114.8$

Data matched that reported in the literature. ${ }^{11}$<smiles>C=C(c1ccccc1)c1cccc(Cl)c1</smiles>

1-Chloro-3-(1-phenylvinyl)benzene (6a): prepared with methyltriphenylphosphonium bromide; flash chromatography eluting with $5 \%$ EtOAc/hexane afforded the desired product as a yellow liquid $(0.64 \mathrm{~g}, 74 \%$ yield). ${ }^{1} \mathrm{H} \mathrm{NMR}\left(\mathrm{CDCl}_{3}, 400 \mathrm{MHz}\right): \delta=7.39-7.21(\mathrm{~m}, 9 \mathrm{H}), 5.51(\mathrm{~d}, J=0.9 \mathrm{~Hz}, 1 \mathrm{H}), 5.48(\mathrm{~d}, J=0.9 \mathrm{~Hz}, 1 \mathrm{H})$. 
${ }^{13} \mathrm{C} \mathrm{NMR}\left(\mathrm{CDCl}_{3}, 100 \mathrm{MHz}\right): \delta=149.0,143.5,140.9,134.2,129.5,128.44,128.43,128.3,128.1,127.9,126.6$, 115.4 .

Data matched that reported in the literature. ${ }^{12}$<smiles>C=C(c1ccccc1)c1ccc(Cl)cc1</smiles>

1-Chloro-4-(1-phenylvinyl)benzene (7a): prepared with methyltriphenylphosphonium bromide; flash chromatography eluting with 5\% EtOAc/hexane afforded the desired product as a colourless liquid $(0.59 \mathrm{~g}, 68 \%$ yield).

${ }^{1} \mathrm{H} \mathrm{NMR}\left(\mathrm{CDCl}_{3}, 400 \mathrm{MHz}\right): \delta=7.38-7.27(\mathrm{~m}, 9 \mathrm{H}), 5.48(\mathrm{~d}, J=1.1 \mathrm{~Hz}, 1 \mathrm{H}), 5.46(\mathrm{~d}, J=1.1 \mathrm{~Hz}, 1 \mathrm{H})$.

${ }^{13} \mathrm{C} \mathrm{NMR}\left(\mathrm{CDCl}_{3}, 100 \mathrm{MHz}\right): \delta=149.1,141.1,140.1,133.7,129.7,128.5,128.4,128.3,128.1,114.8$.

Data matched that reported in the literature. ${ }^{13}$<smiles>C=C(c1ccccc1)c1ccccn1</smiles>

2-(1-Phenylvinyl)pyridine (11a): prepared with methyltriphenylphosphonium bromide; flash chromatography eluting with $50 \%$ EtOAc/nhexane afforded the desired product as a red liquid $(0.52 \mathrm{~g}, 71 \%$ yield $)$.

${ }^{1} \mathrm{H} \mathrm{NMR}\left(\mathrm{CDCl}_{3}, 400 \mathrm{MHz}\right): \delta=8.66-8.64(\mathrm{~m}, 1 \mathrm{H}), 7.65-7.61(\mathrm{~m}, 1 \mathrm{H}), 7.37-7.33(\mathrm{~m}, 5 \mathrm{H}), 7.28-7.26(\mathrm{~m}, 1 \mathrm{H})$, $7.23-7.21(\mathrm{~m}, 1 \mathrm{H}), 6.00(\mathrm{~d}, J=1.4 \mathrm{~Hz}, 1 \mathrm{H}), 5.62(\mathrm{~d}, J=1.4 \mathrm{~Hz}, 1 \mathrm{H})$.

${ }^{13} \mathrm{C} \mathrm{NMR}\left(\mathrm{CDCl}_{3}, 100 \mathrm{MHz}\right): \delta=158.6,149.5,149.2,140.4,136.4,128.5,128.4,127.9,123.0,122.5,117.9$.

Data matched that reported in the literature. ${ }^{14}$<smiles>C=C(c1ccccc1)c1cccc(C)c1</smiles>

1-Methyl-3-(1-phenylvinyl)benzene (13a): prepared with methyltriphenylphosphonium bromide; flash chromatography eluting with 5\% EtOAc/nhexane afforded the desired product as a colourless liquid. (0.66 g, $85 \%$ yield)

${ }^{1} \mathrm{H}$ NMR $\left(\mathrm{CDCl}_{3}, 400 \mathrm{MHz}\right): \delta=7.38-7.33(\mathrm{~m}, 5 \mathrm{H}), 7.25(\mathrm{~m}, 1 \mathrm{H}), 7.17(\mathrm{~m}, 3 \mathrm{H}), 5.47(\mathrm{~s}, 2 \mathrm{H}), 2.37(\mathrm{~s}, 3 \mathrm{H})$.

${ }^{13} \mathrm{C} \mathrm{NMR}\left(\mathrm{CDCl}_{3}, 100 \mathrm{MHz}\right): \delta=150.3,141.7,141.6,137.9,129.1,128.6,128.4,128.3,128.2,127.8,125.6,114.3$, 21.6 .

Data matched that reported in the literature. ${ }^{15}$ 
<smiles>C=C(c1ccccc1)c1ccc(C)cc1</smiles>

1-Methyl-4-(1-phenylvinyl)benzene (14a): prepared with methyltriphenylphosphonium bromide; flash chromatography eluting with $5 \%$ EtOAc/nhexane afforded the desired product as a colourless liquid $(0.54 \mathrm{~g}, 70 \%$ yield).

${ }^{1} \mathrm{H} \mathrm{NMR}\left(\mathrm{CDCl}_{3}, 400 \mathrm{MHz}\right): \delta=7.38-7.33(\mathrm{~m}, 5 \mathrm{H}), 7.27(\mathrm{~m}, 2 \mathrm{H}), 7.17(\mathrm{~m}, 2 \mathrm{H}), 5.46(\mathrm{~d}, J=1.3 \mathrm{~Hz}, 1 \mathrm{H}), 5.43(\mathrm{~d}, J$ $=1.3 \mathrm{~Hz}, 1 \mathrm{H}), 2.40(\mathrm{~s}, 3 \mathrm{H})$.

${ }^{13} \mathrm{C} \mathrm{NMR}\left(\mathrm{CDCl}_{3}, 100 \mathrm{MHz}\right): \delta=150.0,141.8,138.7,137.6,129.0,128.4,128.3,128.2,127.8,113.8,21.3$.

Data matched that reported in the literature. ${ }^{13}$<smiles>C=C(c1ccccc1)c1ccc(OC)cc1</smiles>

1-Methoxy-4-(1-phenylvinyl)benzene (16a): prepared with methyltriphenylphosphonium bromide; flash chromatography eluting with $5 \%$ EtOAc/nhexane afforded the desired product as a white crystalline solid (0.64 g, $76 \%$ yield).

${ }^{1} \mathrm{H} \mathrm{NMR}\left(\mathrm{CDCl}_{3}, 400 \mathrm{MHz}\right): \delta=7.36-7.31(\mathrm{~m}, 5 \mathrm{H}), 7.30(\mathrm{~d}, J=8.8 \mathrm{~Hz}, 2 \mathrm{H}), 6.87(\mathrm{~d}, J=8.8 \mathrm{~Hz}, 2 \mathrm{H}), 5.40(\mathrm{~d}, J=$ $1.1 \mathrm{~Hz}, 1 \mathrm{H}), 5.36(\mathrm{~d}, J=1.1 \mathrm{~Hz}, 1 \mathrm{H}), 3.83(\mathrm{~s}, 3 \mathrm{H})$

${ }^{13} \mathrm{C} \mathrm{NMR}\left(\mathrm{CDCl}_{3}, 100 \mathrm{MHz}\right): \delta=159.5,149.6,142.0,134.1,129.5,128.5,128.3,127.8,113.7,113.1,55.4$.

Data matched that reported in the literature. ${ }^{9}$<smiles>CC=C(c1ccccc1)c1ccccc1</smiles>

Prop-1-ene-1,1-diyldibenzene (20a): prepared with ethyltriphenylphosphonium bromide; flash chromatography eluting with $2 \% \mathrm{EtOAc/nhexane}$ afforded the desired product as a white solid $(0.58 \mathrm{~g}, 49 \%$ yield).

${ }^{1} \mathrm{H} \mathrm{NMR}\left(\mathrm{CDCl}_{3}, 400 \mathrm{MHz}\right): \delta=7.40-7.36(\mathrm{~m}, 2 \mathrm{H}), 7.33-7.19(\mathrm{~m}, 8 \mathrm{H}), 6.19(\mathrm{q}, J=7.2 \mathrm{~Hz}, 1 \mathrm{H}), 1.77(\mathrm{~d}, J=7.2$ $\mathrm{Hz}, 3 \mathrm{H})$.

${ }^{13} \mathrm{C} \mathrm{NMR}\left(\mathrm{CDCl}_{3}, 100 \mathrm{MHz}\right): \delta=143.1,142.6,140.2,130.2,128.3,128.2,127.3,127.0,126.9,124.3,124.2,15.9$.

Data matched that reported in the literature. ${ }^{15}$<smiles>C=C(c1ccccc1)C1CCCCC1</smiles>

(1-Cyclohexylvinyl)benzene (21a): prepared with methyltriphenylphosphonium bromide; flash chromatography eluting with $5 \%$ EtOAc/nhexane afforded the desired product as a colourless liquid $(0.47 \mathrm{~g}, 63 \%$ yield $)$. 
${ }^{1} \mathrm{H}$ NMR $\left(\mathrm{CDCl}_{3}, 400 \mathrm{MHz}\right): \delta=7.38-7.25(\mathrm{~m}, 5 \mathrm{H}), 5.16(\mathrm{~s}, 1 \mathrm{H}), 5.03(\mathrm{~s}, 1 \mathrm{H}), 2.44(\mathrm{~m}, 1 \mathrm{H}), 1.88-1.71(\mathrm{~m}, 5 \mathrm{H}), 1.40-$ $1.14(\mathrm{~m}, 5 \mathrm{H})$.

${ }^{13} \mathrm{C} \mathrm{NMR}\left(\mathrm{CDCl}_{3}, 100 \mathrm{MHz}\right): \delta=155.1,143.1,128.2,127.1,126.8,110.5,42.7,32.8,27.0,26.6$.

Data matched that reported in the literature. ${ }^{16}$<smiles>C=C1CCCc2ccccc21</smiles>

1-Methylene-1,2,3,4-tetrahydronaphthalene (22a): prepared with methyltriphenylphosphonium bromide; flash chromatography eluting with $5 \% \mathrm{EtOAc} / n$ hexane afforded the desired product as a colourless liquid $(0.17 \mathrm{~g}, 29 \%$ yield).

${ }^{1} \mathrm{H}$ NMR $\left(\mathrm{CDCl}_{3}, 400 \mathrm{MHz}\right): \delta=7.67-7.63(\mathrm{~m}, 1 \mathrm{H}), 7.20-7.09(\mathrm{~m}, 3 \mathrm{H}), 5.48(\mathrm{~m}, 1 \mathrm{H}), 4.95(\mathrm{~m}, 1 \mathrm{H}), 2.87-2.84(\mathrm{~m}$, $2 \mathrm{H}), 2.57-2.53(\mathrm{~m}, 2 \mathrm{H}), 1.92-1.86(\mathrm{~m}, 2 \mathrm{H})$.

${ }^{13} \mathrm{C} \mathrm{NMR}\left(\mathrm{CDCl}_{3}, 126 \mathrm{MHz}\right): \delta=143.6,137.5,134.9,129.3,127.7,126.0,124.3,108.0,33.4,30.6,24.0$.

Data matched that reported in the literature. ${ }^{17}$<smiles>C=C(c1ccccc1)C1CCC1</smiles>

(1-Cyclobutylvinyl)benzene (23a): prepared with methyltriphenylphosphonium bromide; flash chromatography eluting with $5 \%$ EtOAc/nhexane afforded the desired product as a colourless liquid $(0.49 \mathrm{~g}, 78 \%$ yield $)$.

${ }^{1} \mathrm{H} \mathrm{NMR}\left(\mathrm{CDCl}_{3}, 400 \mathrm{MHz}\right): \delta=7.41-7.38(\mathrm{~m}, 2 \mathrm{H}), 7.33(\mathrm{~m}, 2 \mathrm{H}), 7.29-7.25(\mathrm{~m}, 1 \mathrm{H}), 5.37(\mathrm{~m}, 1 \mathrm{H}), 5.06(\mathrm{~m}, 1 \mathrm{H})$, 3.53-3.44 (m, 1H), 2.29-2.18 (m, 2H), 2.06-1.94 (m, 3H), 1.86-1.74 (m, $1 \mathrm{H})$.

${ }^{13} \mathrm{C} \mathrm{NMR}\left(\mathrm{CDCl}_{3}, 100 \mathrm{MHz}\right): \delta=152.1,140.8,128.3,127.3,126.2,109.9,39.7,28.5,17.9$.

Data matched that reported in the literature. ${ }^{18}$<smiles>C=C(CCC)c1ccccc1</smiles>

Pent-1-en-2-ylbenzene (25a): prepared with methyltriphenylphosphonium bromide; flash chromatography eluting with $5 \% \mathrm{EtOAc/nhexane}$ afforded the desired product as a colourless liquid $(0.28 \mathrm{~g}, 48 \%$ yield).

${ }^{1} \mathrm{H} \mathrm{NMR}\left(\mathrm{CDCl}_{3}, 400 \mathrm{MHz}\right): \delta=7.43(\mathrm{~d}, J=7.8 \mathrm{~Hz}, 2 \mathrm{H}), 7.37-7.33(\mathrm{~m}, 2 \mathrm{H}), 7.30-7.26(\mathrm{~m}, 1 \mathrm{H}), 5.30(\mathrm{~s}, 1 \mathrm{H}), 5.08$ (s, $1 \mathrm{H}), 2.53-2.49(\mathrm{~m}, 2 \mathrm{H}), 1.55-1.46(\mathrm{~m}, 2 \mathrm{H}), 0.95(\mathrm{t}, J=7.4 \mathrm{~Hz}, 3 \mathrm{H})$.

${ }^{13} \mathrm{C} \mathrm{NMR}\left(\mathrm{CDCl}_{3}, 100 \mathrm{MHz}\right): \delta=148.6,141.6,128.3,127.4,126.3,112.3,37.6,21.5,13.9$.

Data matched that reported in the literature. ${ }^{19}$ 
<smiles>C=C(c1ccccc1)C(C)C</smiles>

(3-Methylbut-1-en-2-yl)benzene (26a): prepared with methyltriphenylphosphonium bromide; flash chromatography eluting with $5 \%$ EtOAc/nhexane afforded the desired product as a colourless liquid $(0.27 \mathrm{~g}, 46 \%$ yield).

${ }^{1} \mathrm{H} \mathrm{NMR}\left(\mathrm{CDCl}_{3}, 400 \mathrm{MHz}\right): \delta=7.39-7.26(\mathrm{~m}, 5 \mathrm{H}), 5.17(\mathrm{~m}, 1 \mathrm{H}), 5.06(\mathrm{~m}, 1 \mathrm{H}), 2.86(\mathrm{~m}, 1 \mathrm{H}), 1.13(\mathrm{~d}, J=6.8 \mathrm{~Hz}$, $6 \mathrm{H})$.

${ }^{13} \mathrm{C} \mathrm{NMR}\left(\mathrm{CDCl}_{3}, 100 \mathrm{MHz}\right): \delta=155.9,143.0,128.3,127.2,126.7,110.1,32.4,22.2$.

Data matched that reported in the literature. ${ }^{18}$<smiles>C=C(CCCCC)c1ccccc1</smiles>

Hept-1-en-2-ylbenzene (27a): prepared with methyltriphenylphosphonium bromide; flash chromatography eluting with $5 \% \mathrm{EtOAc} / n$ hexane afforded the desired product as a colourless liquid $(0.34 \mathrm{~g}, 49 \%$ yield).

${ }^{1} \mathrm{H} \mathrm{NMR}\left(\mathrm{CDCl}_{3}, 400 \mathrm{MHz}\right): \delta=7.44-7.42(\mathrm{~m}, 2 \mathrm{H}), 7.37-7.32(\mathrm{~m}, 2 \mathrm{H}), 7.30-7.26(\mathrm{~m}, 1 \mathrm{H}), 5.28(\mathrm{~d}, \mathrm{~J}=1.5 \mathrm{~Hz}, 1 \mathrm{H})$, $5.08(\mathrm{~d}, J=1.4 \mathrm{~Hz}, 1 \mathrm{H}), 2.53-2.50(\mathrm{~m}, 2 \mathrm{H}), 1.51-1.44(\mathrm{~m}, 2 \mathrm{H}), 1.37-1.28(\mathrm{~m}, 4 \mathrm{H}), 0.90(\mathrm{~m}, 3 \mathrm{H})$.

${ }^{13} \mathrm{C} \mathrm{NMR}\left(\mathrm{CDCl}_{3}, 100 \mathrm{MHz}\right): \delta=148.9,141.6,128.4,127.4,126.2,112.1,35.5,31.7,28.1,22.7,14.2$.

Data matched that reported in the literature. ${ }^{20}$<smiles>C=C(CC)c1ccc(Cl)c(Cl)c1</smiles>

4-(But-1-en-2-yl)-1,2-dichlorobenzene (28a): prepared with methyltriphenylphosphonium bromide; flash chromatography eluting with 5\% EtOAc/nhexane afforded the desired product as a colourless liquid $(0.44 \mathrm{~g}, 54 \%$ yield).

${ }^{1} \mathrm{H} \mathrm{NMR}\left(\mathrm{CDCl}_{3}, 400 \mathrm{MHz}\right): \delta=7.48(\mathrm{~d}, J=2.1 \mathrm{~Hz}, 1 \mathrm{H}), 7.38(\mathrm{~d}, J=8.4 \mathrm{~Hz}, 1 \mathrm{H}), 7.23(\mathrm{dd}, J=8.4,2.1 \mathrm{~Hz}, 1 \mathrm{H})$, $5.28(\mathrm{~m}, 1 \mathrm{H}), 5.11(\mathrm{~m}, 1 \mathrm{H}), 2.46(\mathrm{~m}, 2 \mathrm{H}), 1.09(\mathrm{~m}, 3 \mathrm{H})$.

${ }^{13} \mathrm{C} \mathrm{NMR}\left(\mathrm{CDCl}_{3}, 100 \mathrm{MHz}\right): \delta=148.0,141.7,132.4,131.2,130.2,128.1,125.5,112.7,28.0,12.9$.<smiles>C=C(c1ccccc1)C(OC)(OC)c1ccccc1</smiles>

(1,1-Dimethoxyprop-2-ene-1,2-diyl)dibenzene (30a): prepared with methyltriphenylphosphonium bromide; flash chromatography eluting with $5 \% \mathrm{EtOAc} / n$ hexane afforded the desired product as a colourless liquid $(0.51 \mathrm{~g}, 50 \%$ yield).

${ }^{1} \mathrm{H} \mathrm{NMR}\left(\mathrm{CDCl}_{3}, 400 \mathrm{MHz}\right): \delta=7.53-7.51(\mathrm{~m}, 2 \mathrm{H}), 7.30-7.20(\mathrm{~m}, 3 \mathrm{H}), 7.17-7.10(\mathrm{~m}, 5 \mathrm{H}), 6.02(\mathrm{~d}, J=1.9 \mathrm{~Hz}, 1 \mathrm{H})$, $5.59(\mathrm{~d}, J=1.9 \mathrm{~Hz}, 1 \mathrm{H}), 3.16(\mathrm{~s}, 6 \mathrm{H})$. 
${ }^{13} \mathrm{C} \mathrm{NMR}\left(\mathrm{CDCl}_{3}, 100 \mathrm{MHz}\right): \delta=148.4,140.2,139.6,128.0,127.9,127.8,127.7,127.5,127.2,118.5,102.4,49.1$<smiles>C=C(CC)c1ccccc1F</smiles>

1-(But-1-en-2-yl)-2-fluorobenzene (31a): prepared with methyltriphenylphosphonium bromide; flash chromatography eluting with $5 \%$ EtOAc/nhexane afforded the desired product as a colourless liquid $(0.17 \mathrm{~g}, 28 \%$ yield).

${ }^{1} \mathrm{H} \mathrm{NMR}\left(\mathrm{CDCl}_{3}, 400 \mathrm{MHz}\right): \delta=7.27-7.20(\mathrm{~m}, 2 \mathrm{H}), 7.11-7.01(\mathrm{~m}, 2 \mathrm{H}), 5.22(\mathrm{~m}, 1 \mathrm{H}), 5.14(\mathrm{~m}, 1 \mathrm{H}), 2.48(\mathrm{q}, J=7.4$ $\mathrm{Hz}, 2 \mathrm{H}), 1.05(\mathrm{t}, J=7.4 \mathrm{~Hz}, 3 \mathrm{H})$.

${ }^{13} \mathrm{C} \mathrm{NMR}\left(\mathrm{CDCl}_{3}, 100 \mathrm{MHz}\right): \delta=160.0\left(\mathrm{~d}, J_{C-F}=247.0 \mathrm{~Hz}\right), 146.8,130.4\left(\mathrm{~d}, J_{C-F}=14.7 \mathrm{~Hz}\right), 130.1\left(\mathrm{~d}, J_{C-F}=3.9\right.$ $\mathrm{Hz}), 128.7\left(\mathrm{~d}, J_{C-F}=8.2 \mathrm{~Hz}\right), 124.0\left(\mathrm{~d}, J_{C-F}=3.3 \mathrm{~Hz}\right), 115.8\left(\mathrm{~d}, J_{C-F}=23.0 \mathrm{~Hz}\right), 114.5,29.5,12.8$.

$\left.{ }^{19} \mathrm{~F} \mathrm{NMR} \mathrm{(376} \mathrm{MHz,} \mathrm{CDCl}_{3}\right): \delta=-115.5$.<smiles>C=C(C)c1ccc2ccccc2c1</smiles>

2-(Prop-1-en-2-yl)naphthalene (32a): prepared with methyltriphenylphosphonium bromide; flash chromatography eluting with $1 \% \mathrm{EtOAc/nhexane}$ afforded the desired product as a white crystalline solid $(0.53 \mathrm{~g}, 79 \%$ yield).

${ }^{1} \mathrm{H}$ NMR $\left(\mathrm{CDCl}_{3}, 400 \mathrm{MHz}\right): \delta=7.88-7.80(\mathrm{~m}, 4 \mathrm{H}), 7.72-7.69(\mathrm{~m}, 1 \mathrm{H}), 7.51-7.47(\mathrm{~m}, 2 \mathrm{H}), 5.57(\mathrm{~m}, 1 \mathrm{H}), 5.23-5.22$ $(\mathrm{m}, 1 \mathrm{H}), 2.30-2.29(\mathrm{~m}, 3 \mathrm{H})$.

${ }^{13} \mathrm{C} \mathrm{NMR}\left(\mathrm{CDCl}_{3}, 100 \mathrm{MHz}\right): \delta=143.1,138.4,133.5,132.9,128.4,127.8,127.6,126.2,125.9,124.4,124.0,113.2$ 22.0 .

Data matched that reported in the literature. ${ }^{21}$<smiles>C=Cc1cccc(Oc2ccc(OC)cc2)c1</smiles>

1-(4-Methoxyphenoxy)-3-vinylbenzene (33a): prepared with methyltriphenylphosphonium bromide; flash chromatography eluting with $5 \% \mathrm{EtOAc} / n$ hexane afforded the desired product as a colourless liquid $(0.83 \mathrm{~g}, 79 \%$ yield).

${ }^{1} \mathrm{H} \mathrm{NMR}\left(\mathrm{CDCl}_{3}, 400 \mathrm{MHz}\right): \delta=7.25(\mathrm{t}, J=7.8 \mathrm{~Hz}, 1 \mathrm{H}), 7.10(\mathrm{~d}, J=7.6 \mathrm{~Hz}, 1 \mathrm{H}), 7.00-6.98(\mathrm{~m}, 3 \mathrm{H}), 6.90-6.88(\mathrm{~m}$, $2 \mathrm{H}), 6.84(\mathrm{dd}, J=7.6,2.4 \mathrm{~Hz}, 1 \mathrm{H}), 6.66(\mathrm{dd}, J=17.6,10.8 \mathrm{~Hz}, 1 \mathrm{H}), 5.72(\mathrm{~d}, J=17.6 \mathrm{~Hz}, 1 \mathrm{H}), 5.25(\mathrm{~d}, J=10.8 \mathrm{~Hz}$, $1 \mathrm{H}), 3.82(\mathrm{~s}, 3 \mathrm{H})$.

${ }^{13} \mathrm{C} \mathrm{NMR}\left(\mathrm{CDCl}_{3}, 100 \mathrm{MHz}\right): \delta=158.6,156.0,150.2,139.4,136.5,129.8,120.9,120.7,117.1,115.3,115.0,114.6$ 55.8 . 
(1)

1-(But-1-en-1-yl)-4-methoxybenzene (38a): prepared with $n$-propyltriphenylphosphonium iodide; flash chromatography eluting with 5\% EtOAc/nhexane afforded the desired product as a colourless liquid $(0.121 \mathrm{~g}, 63 \%$ yield, 2.6:1 E/Z ratio).

${ }^{1} \mathrm{H} \mathrm{NMR}\left(\mathrm{CDCl}_{3}, 400 \mathrm{MHz}\right): \delta=7.29-7.27(\mathrm{~m}, 2 \mathrm{H}, E$ isomer $), 7.23-7.21(\mathrm{~m}, 2 \mathrm{H}, \mathrm{Z}$ isomer), $6.88-6.86(\mathrm{~m}, 2 \mathrm{H}$, $Z$ isomer), $6.85-6.83(\mathrm{~m}, 2 \mathrm{H}, E$ isomer), $6.34-6.30(\mathrm{~m}, 1 \mathrm{H}$, both isomers), $6.13(\mathrm{dt}, \mathrm{J}=15.6,6.4 \mathrm{~Hz}, 1 \mathrm{H}, E$ isomer), 5.57 (dt, $J=11.6,7.2 \mathrm{~Hz}, 1 \mathrm{H}, Z$ isomer), 3.81 (s, 3H, $Z$ isomer), 3.80 (s, 3H, $E$ isomer), $2.38-2.30$ (m, $2 \mathrm{H}, \mathrm{Z}$ isomer), $2.25-2.17(\mathrm{~m}, 2 \mathrm{H}, \mathrm{E}$ isomer $), 1.08(\mathrm{~m}, 3 \mathrm{H}$, both isomers).

${ }^{13} \mathrm{C} \mathrm{NMR}\left(\mathrm{CDCl}_{3}, 100 \mathrm{MHz}\right): \delta=158.7$ ( $E$ isomer), 158.3 ( $Z$ isomer), 130.7 ( $Z$ isomer), 130.6 ( $E$ isomer), $130.0(Z$ isomer), 128.2 ( $E$ isomer), 127.8 ( $Z$ isomer), 127.1 ( $E$ isomer), 114.0 ( $E$ isomer), 113.7 ( $Z$ isomer), 55.4 (both isomers), 26.2 ( $E$ isomer), 22.1 ( $Z$ isomer), 14.7 ( $Z$ isomer), 14.0 ( $E$ isomer).

Data matched that reported in the literature. ${ }^{22}$

\section{Synthesis of $N$-(4-(1-phenylvinyl)phenyl)acetamide (10a)}

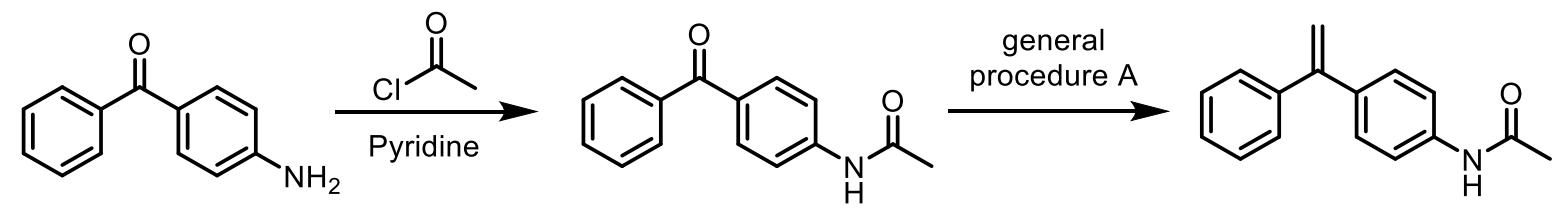

4-Aminobenzophenone (5.0 mmol 1.0 equiv.) was taken up in pyridine and the solution was cooled to $0{ }^{\circ} \mathrm{C}$. Acetyl chloride $\left(6.0 \mathrm{mmol}, 1.1\right.$ equiv.) was added dropwise at $0{ }^{\circ} \mathrm{C}$ and the solution was stirred at room temperature for 5 hours. The reaction mixture was diluted with dichloromethane and washed with aqueous $\mathrm{HCl}$ solution $(1 \mathrm{M})$ and water. The organic layer was dried with $\mathrm{MgSO}_{4}$ and the solvent removed under reduced pressure. The crude material was used directly in the next step without further purification.

The crude reaction mixture was then subjected to general procedure A. The product was purified by flash chromatography on silica, eluting with $50 \%$ EtOAc/petroleum ether to give the desired product as an orange crystalline solid. $(0.34 \mathrm{~g}, 28 \%$ yield over 2 steps)

${ }^{1} \mathrm{H} \mathrm{NMR}\left(\mathrm{CDCl}_{3}, 400 \mathrm{MHz}\right): \delta=7.63(\mathrm{~s}, 1 \mathrm{H}), 7.48(\mathrm{~d}, J=8.2 \mathrm{~Hz}, 2 \mathrm{H}), 7.28(\mathrm{t}, J=7.9 \mathrm{~Hz}, 7 \mathrm{H}), 5.43(\mathrm{~s}, 1 \mathrm{H}), 5.40(\mathrm{~s}$, $1 \mathrm{H}), 2.18(\mathrm{~s}, 3 \mathrm{H})$.

${ }^{13} \mathrm{C} \mathrm{NMR}\left(\mathrm{CDCl}_{3}, 100 \mathrm{MHz}\right): \delta=168.7,149.5,141.5,137.58,137.57,128.9,128.4,128.3,127.9,119.7,114.0$, 24.7.

Data matched that reported in the literature. ${ }^{11}$ 


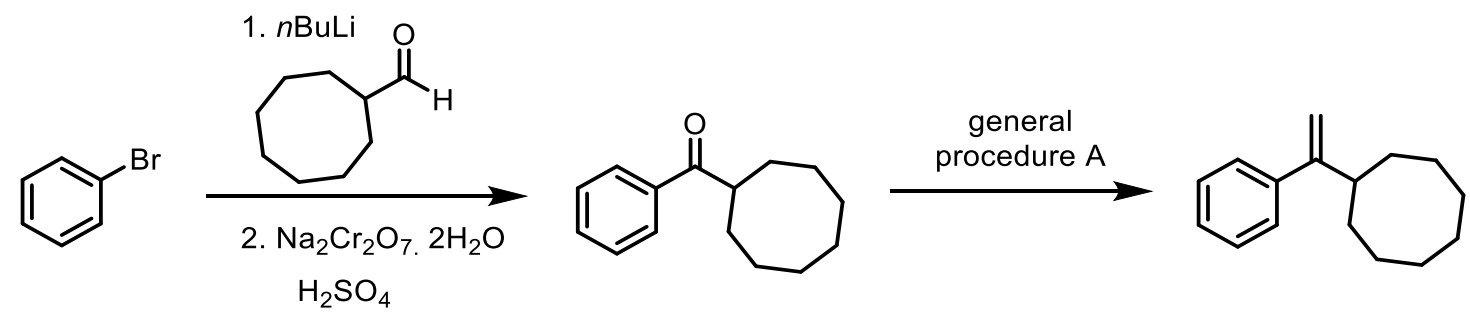

A solution of $n \mathrm{BuLi}$ in hexanes $\left(\mathrm{C}=1.6 \mathrm{M}, 12 \mathrm{mmol}, 1.2\right.$ equiv.) was added dropwise, at $-78{ }^{\circ} \mathrm{C}$, to a solution of bromobenzene $\left(10 \mathrm{mmol}, 1.0\right.$ equiv.) in THF $(100 \mathrm{~mL})$. The reaction mixture was stirred at $-78^{\circ} \mathrm{C}$ for 1 hour. Cyclooctanecarbaldehyde (11 mmol, 1.1 equiv.) was added dropwise at $-78^{\circ} \mathrm{C}$ and the reaction mixture was stirred at room temperature overnight. It was quenched with saturated $\mathrm{NH}_{4} \mathrm{Cl}$ solution and extracted with $\mathrm{EtOAc}(3 \times 40$ $\mathrm{mL})$. The combined organic layers were washed with brine $(3 \times)$ and dried $\left(\mathrm{MgSO}_{4}\right)$. The solvent was removed under reduced pressure. The residue was then dissolved in DMSO and added to a stirred suspension of sodium dichromate dihydrate $\left(5.28 \mathrm{mmol}, 0.66\right.$ equiv.) in DMSO. The reaction mixture was cooled to $0{ }^{\circ} \mathrm{C}$ and concentrated sulfuric acid (21.3 mmol, 2.66 equiv.) was added dropwise. After stirring at room temperature for 30 minutes the reaction mixture was poured onto ice and extracted with $\mathrm{Et}_{2} \mathrm{O}(2 \times 40 \mathrm{~mL})$. The combined organic extracts were washed with saturated aqueous $\mathrm{NaHCO}_{3}$ solution, dried with $\mathrm{MgSO}_{4}$ and concentrated under reduced pressure.

The crude reaction mixture was subjected to general procedure A. Purification by flash chromatography on silica eluting with $1 \% \mathrm{EtOAc/nhexane}$ afforded the desired product as a colourless liquid $(0.33 \mathrm{~g}, 19 \%$ yield over 3 steps $)$ ${ }^{1} \mathrm{H} \mathrm{NMR}\left(\mathrm{CDCl}_{3}, 400 \mathrm{MHz}\right): \delta=7.38-7.24(\mathrm{~m}, 5 \mathrm{H}), 5.15(\mathrm{~s}, 1 \mathrm{H}), 5.03(\mathrm{~s}, 1 \mathrm{H}), 2.75-2.70(\mathrm{~m}, 1 \mathrm{H}), 1.84-1.49(\mathrm{~m}, 14 \mathrm{H})$.

${ }^{13} \mathrm{C} \mathrm{NMR}\left(\mathrm{CDCl}_{3}, 100 \mathrm{MHz}\right): \delta=156.3,143.5,128.3,127.1,126.8,111.0,42.4,31.7,27.3,26.4,25.7$.

\section{Synthesis of (3-phenoxyprop-1-en-2-yl)benzene (29a)}<smiles>O=C(CBr)c1ccccc1</smiles><smiles>Cc1cccc(O)c1</smiles><smiles>O=C(COc1ccccc1)c1ccccc1</smiles>

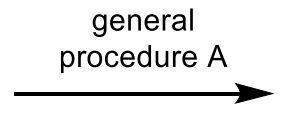<smiles>C=C(COc1ccccc1)c1ccccc1</smiles>

A solution of 2-bromoacetophenone $(5.0 \mathrm{mmol}, 1.0$ equiv.) in acetone (50 $\mathrm{mL})$ was added dropwise, at room temperature, to a suspension of phenol $\left(5.5 \mathrm{mmol}, 1.1\right.$ equiv.) and $\mathrm{K}_{2} \mathrm{CO}_{3}$ ( $7.6 \mathrm{mmol}, 1.5$ equiv) in acetone. The reaction mixture was heated at reflux for 4 hours. The suspension was filtered through a plug of Celite with dichloromethane and the filtrate was concentrated under reduced pressure. Recrystallization from petroleum ether gave 2-phenoxy-1-phenylethan-1-one as a white solid $(0.66 \mathrm{~g}, 62 \%$ yield).

2-Phenoxy-1-phenylethan-1-one was subjected to general procedure A. Purification by flash chromatography on silica, eluting with $10 \% \mathrm{EtOAc/nhexane} \mathrm{gave} \mathrm{the} \mathrm{title} \mathrm{compound} \mathrm{as} \mathrm{a} \mathrm{colourless} \mathrm{liquid}(0.40 \mathrm{~g}, 61 \%$ yield).

${ }^{1} \mathrm{H}$ NMR $\left(\mathrm{CDCl}_{3}, 400 \mathrm{MHz}\right): \delta=7.51(\mathrm{~m}, 2 \mathrm{H}), 7.41-7.30(\mathrm{~m}, 5 \mathrm{H}), 7.02-6.98(\mathrm{~m}, 3 \mathrm{H}), 5.65(\mathrm{~d}, \mathrm{~J}=0.8 \mathrm{~Hz}, 1 \mathrm{H}), 5.50$ (d, $J=1.1 \mathrm{~Hz}, 1 \mathrm{H}), 4.93(\mathrm{~s}, 2 \mathrm{H})$.

${ }^{13} \mathrm{C} \mathrm{NMR}\left(\mathrm{CDCl}_{3}, 100 \mathrm{MHz}\right): \delta=158.7,143.1,138.5,129.6,128.6,128.1,126.2,121.1,115.04,114.96,69.9$. 
<smiles>CCOC(=O)CC/C=C\c1ccc(OC)cc1</smiles>

A solution of NaHMDS in toluene $\left(\mathrm{C}=0.6 \mathrm{M}, 1.1 \mathrm{mmol}, 1.0\right.$ equiv.) was added dropwise, at $0{ }^{\circ} \mathrm{C}$, to a solution of a (3-ethoxycarbonylpropyl)triphenylphosphonium bromide (1.1 mmol, 1.0 equiv.) in dry THF (5 mL). The reaction mixture was stirred at $0{ }^{\circ} \mathrm{C}$ for 30 minutes. A solution of 4 -methoxybenzaldehyde $(1.1 \mathrm{mmol}, 1.0$ equiv.) in dry THF $(3 \mathrm{~mL})$ was added dropwise at $0{ }^{\circ} \mathrm{C}$, and the reaction mixture was stirred at room temperature overnight. It was then diluted with brine and extracted with EtOAc $(3 \times 40 \mathrm{~mL})$. The combined organic extracts were washed with brine (3x) and dried with $\mathrm{MgSO}_{4}$. The solvent removed under reduced pressure and the residue was purified by flash chromatography on silica eluting with $10 \% \mathrm{EtOAc/nhexane} \mathrm{to} \mathrm{yield} \mathrm{the} \mathrm{desired} \mathrm{product} \mathrm{as} \mathrm{a} \mathrm{colourless} \mathrm{oil}(0.052 \mathrm{~g}$, $20 \%$ yield).

${ }^{1} \mathrm{H} \mathrm{NMR}\left(\mathrm{CDCl}_{3}, 400 \mathrm{MHz}\right): \delta=7.23-7.21(\mathrm{~m}, 2 \mathrm{H}), 6.89-6.86(\mathrm{~m}, 2 \mathrm{H}), 6.40(\mathrm{~d}, J=11.6 \mathrm{~Hz}, 1 \mathrm{H}), 5.52(\mathrm{dt}, J=$ 11.6, 7.2 Hz, 1H), $4.13(\mathrm{q}, J=7.2 \mathrm{~Hz}, 2 \mathrm{H}), 3.81(\mathrm{~s}, 3 \mathrm{H}), 2.68-2.62(\mathrm{~m}, 2 \mathrm{H}), 2.45-2.41(\mathrm{~m}, 2 \mathrm{H}), 1.24(\mathrm{t}, J=7.2$ $\mathrm{Hz}, 3 \mathrm{H})$.

${ }^{13} \mathrm{C} \mathrm{NMR}\left(\mathrm{CDCl}_{3}, 100 \mathrm{MHz}\right): \delta=173.2,158.5,130.1,130.0,129.6,128.9,113.8,60.6,55.5,34.6,34.4,24.2,22.9$, 14.4 .

Data matched that reported in the literature. ${ }^{23}$

\section{Method B}<smiles>[R]c1ccc(C(C)=O)cc1</smiles>

A suspension of Mg turnings ( $9.0 \mathrm{mmol}, 1.5$ equiv.) and several crystals of iodine in dry THF (10 mL) was stirred at room temperature for 10 minutes. Aryl bromide $(9.0 \mathrm{mmol}, 1.5$ equiv.) was added dropwise at room temperature, and the reaction mixture was then stirred at $40{ }^{\circ} \mathrm{C}$ for 1 hour. After cooling to $0{ }^{\circ} \mathrm{C}$, acetophenone $(6.0 \mathrm{mmol}, 1.0$ equiv.) was added dropwise, and the reaction mixture was stirred at room temperature overnight. It was quenched with saturated aqueous $\mathrm{NH}_{4} \mathrm{Cl}$ solution and extracted with EtOAc $(3 \times 40 \mathrm{~mL})$. The combined organic extracts were washed with brine $(3 \times)$ and dried $\left(\mathrm{MgSO}_{4}\right)$. The solvent was removed by reduced pressure and the residue used directly without further purification.

The crude reaction mixture was taken up in toluene containing $p$-toluene sulfonic acid $(0.8 \mathrm{mmol}, 20 \mathrm{~mol} \%)$. The solution was heated at reflux overnight under Dean-Stark conditions. It was cooled to room temperature, washed with brine and extracted with EtOAc $(3 \times 40 \mathrm{~mL})$. The combined organic extracts were washed with brine $(3 \times)$ and dried $\left(\mathrm{MgSO}_{4}\right)$. The solvent was removed under reduced pressure and the residue was purified by flash chromatography on silica eluting with 1-5\% EtOAc/nhexane to yield the desired product. 


\section{Substrates synthesized using method B:}<smiles>C=C(c1ccccc1)c1ccc(C(F)(F)F)cc1</smiles>

1-(1-Phenylvinyl)-4-(trifluoromethyl)benzene $\quad(5 \mathbf{a})$ : prepared using acetophenone and 4trifluoromethylphenylmagnesium bromide; flash chromatography on silica eluting with $1 \%$ EtOAc/nhexane afforded the desired product as a light yellow solid $(1.33 \mathrm{~g}, 67 \%$ yield).

${ }^{1} \mathrm{H} \mathrm{NMR}\left(\mathrm{CDCl}_{3}, 400 \mathrm{MHz}\right): \delta=7.61(\mathrm{~m}, 2 \mathrm{H}), 7.46(\mathrm{~m}, 2 \mathrm{H}), 7.39-7.31(\mathrm{~m}, 5 \mathrm{H}), 5.58(\mathrm{~d}, J=0.8 \mathrm{~Hz}, 1 \mathrm{H}), 5.53(\mathrm{~d}, J$ $=0.8 \mathrm{~Hz}, 1 \mathrm{H})$.

${ }^{13} \mathrm{C} \mathrm{NMR}\left(\mathrm{CDCl}_{3}, 100 \mathrm{MHz}\right): \delta=149.1,145.2,140.8,129.9(\mathrm{q}, J=32.4 \mathrm{~Hz}), 128.7,128.5,128.3,128.2,125.3$ (q, $J=3.8 \mathrm{~Hz}), 124.4(\mathrm{q}, J=272.7 \mathrm{~Hz}), 116.1$.

${ }^{19} \mathrm{~F} \mathrm{NMR}\left(376 \mathrm{MHz}, \mathrm{CDCl}_{3}\right): \delta=-62.5$

Data matched that reported in the literature. ${ }^{11}$<smiles>C=C(c1ccccc1)c1ccccc1C</smiles>

1-Methyl-2-(1-phenylvinyl)benzene (12a): prepared using 2'-methylacetophenone and phenylmagnesium bromide; flash chromatography on silica eluting with $5 \%$ EtOAc/nhexane afforded the desired product as a colourless liquid $(0.63 \mathrm{~g}, 81 \%$ yield $)$.

${ }^{1} \mathrm{H} \mathrm{NMR}\left(\mathrm{CDCl}_{3}, 400 \mathrm{MHz}\right): \delta=7.34-7.21(\mathrm{~m}, 9 \mathrm{H}), 5.80(\mathrm{~d}, J=1.1 \mathrm{~Hz}, 1 \mathrm{H}), 5.23(\mathrm{~d}, J=1.1 \mathrm{~Hz}, 1 \mathrm{H}), 2.08(\mathrm{~s}, 3 \mathrm{H})$. ${ }^{13} \mathrm{C} \mathrm{NMR}\left(\mathrm{CDCl}_{3}, 100 \mathrm{MHz}\right): \delta=149.6,141.7,140.7,136.3,130.2,130.1,128.5,127.69,127.65,126.6,125.8$, $115.0,20.3$

Data matched that reported in the literature. ${ }^{11}$<smiles>C=C(c1ccccc1)c1ccc(Br)cc1</smiles>

1-(tert-Butyl)-4-(1-phenylvinyl)benzene (15a): prepared using acetophenone and 4-tert-butylphenylmagnesium bromide; flash chromatography on silica eluting with $1 \%$ EtOAc/nhexane afforded the desired product as a colourless oil $(0.09 \mathrm{~g}, 5 \%$ yield $)$.

${ }^{1} \mathrm{H}$ NMR $\left(\mathrm{CDCl}_{3}, 400 \mathrm{MHz}\right): \delta=7.38-7.26(\mathrm{~m}, 9 \mathrm{H}), 5.46(\mathrm{~s}, 1 \mathrm{H}), 5.41(\mathrm{~s}, 1 \mathrm{H}), 1.34(\mathrm{~s}, 9 \mathrm{H})$.

${ }^{13} \mathrm{C} \mathrm{NMR}\left(\mathrm{CDCl}_{3}, 100 \mathrm{MHz}\right): \delta=150.9,149.9,141.8,138.5,128.5,128.2,128.0,127.7,125.2,113.9,34.7,31.5$.

Data matched that reported in the literature. ${ }^{13}$ 
<smiles>C=C(c1ccc(OC)cc1)c1ccccc1C</smiles>

1-(1-(4-Methoxyphenyl)vinyl)-2-methylbenzene (17a): prepared using 2'-methylacetophenone and 4methoxyphenylmagnesium bromide; vacuum distillation $\left(135-145^{\circ} \mathrm{C}, \pm 1 \mathrm{mbar}\right)$ afforded the desired product as a colourless liquid $(0.75 \mathrm{~g}, 84 \%$ yield $)$.

${ }^{1} \mathrm{H} \mathrm{NMR}\left(\mathrm{CDCl}_{3}, 400 \mathrm{MHz}\right): \delta=7.28-7.17(\mathrm{~m}, 6 \mathrm{H}), 6.83-6.80(\mathrm{~m}, 2 \mathrm{H}), 5.68(\mathrm{~d}, J=1.4 \mathrm{~Hz}, 1 \mathrm{H}), 5.08(\mathrm{~d}, J=1.4 \mathrm{~Hz}$, $1 \mathrm{H}), 3.80(\mathrm{~s}, 3 \mathrm{H}), 2.06(\mathrm{~s}, 3 \mathrm{H})$.

${ }^{13} \mathrm{C} \mathrm{NMR}\left(\mathrm{CDCl}_{3}, 100 \mathrm{MHz}\right): \delta=159.3,148.9,142.0,136.3,133.3,130.15,130.05,127.8,127.5,125.8,113.8$, 113.0, 55.4, 20.2.

Data matched that reported in the literature. ${ }^{15}$<smiles>C=C(c1ccc(OC)cc1)c1cc(OC)c(OC)c(OC)c1</smiles>

1,2,3-Trimethoxy-5-(1-(4-methoxyphenyl)vinyl)benzene (19a): prepared using 3',4',5'-trimethoxy acetophenone and 4-methoxyphenylmagnesium bromide; flash chromatography on silica eluting with $50 \%$ EtOAc/nhexane afforded the desired product as a pale yellow oil ( $0.76 \mathrm{~g}, 53 \%$ yield).

${ }^{1} \mathrm{H} \mathrm{NMR}\left(\mathrm{CDCl}_{3}, 400 \mathrm{MHz}\right): \delta=7.32-7.28(\mathrm{~m}, 2 \mathrm{H}), 6.89-6.85(\mathrm{~m}, 2 \mathrm{H}), 6.56(\mathrm{~s}, 2 \mathrm{H}), 5.37(\mathrm{~d}, \mathrm{~J}=1.2 \mathrm{~Hz}, 1 \mathrm{H}), 5.32$ (d, J = $1.2 \mathrm{~Hz}, 1 \mathrm{H}), 3.88(\mathrm{~s}, 3 \mathrm{H}), 3.83(\mathrm{~s}, 3 \mathrm{H}), 3.81(\mathrm{~s}, 6 \mathrm{H})$.

${ }^{13} \mathrm{C} \mathrm{NMR}\left(\mathrm{CDCl}_{3}, 100 \mathrm{MHz}\right): \delta=159.5,152.9,149.6,137.8,137.7,133.8,129.5,113.6,112.6,105.7,61.1,56.2$, 55.4 .

Data matched that reported in the literature. ${ }^{24}$

Synthesis of 2-(1-(2,3-dimethylphenyl)vinyl)-1H-imidazole (18a) ${ }^{25}$<smiles>C=C(c1ncc[nH]1)c1cccc(C(C)C)c1C(=O)O</smiles>

Imidazole (10 mmol, 1.0 equiv.) and $p$-toluene sulfonic acid $(0.3 \mathrm{mmol}, 3.0 \mathrm{~mol} \%)$ were dissolved in triethyl orthoformate (40 mmol, 4.0 equiv.) and the reaction mixture was stirred at $130{ }^{\circ} \mathrm{C}$ until all methanol was distilled. The remaining triethyl orthoformate was removed by vacuum distillation $\left(75-79^{\circ} \mathrm{C}, \pm 4 \mathrm{mbar}\right)$ affording the product as a clear oil. ( $1.45 \mathrm{~g}, 42 \%$ yield.).

1-(Diethoxymethyl)- $1 \mathrm{H}$-imidazole $\left(5.0 \mathrm{mmol}, 1.0\right.$ equiv.) was dissolved in dry THF and cooled to $-78^{\circ} \mathrm{C}$. A solution of $n \mathrm{BuLi}$ in hexanes ( $\mathrm{C}=1.6 \mathrm{M}, 5 \mathrm{mmol}, 1.0$ equiv.) was added dropwise, and the reaction mixture was stirred at $78{ }^{\circ} \mathrm{C}$ for 3 hours. 1-(2,3-Dimethylphenyl)ethanone $\left(5.5 \mathrm{mmol}, 1.1\right.$ equiv.) was added dropwise at $-78^{\circ} \mathrm{C}$ and the 
solution was stirred at $-78{ }^{\circ} \mathrm{C}$ for 10 minutes, and at room temperature overnight. The reaction mixture was quenched with saturated aqueous $\mathrm{NH}_{4} \mathrm{Cl}$ solution and extracted with EtOAc $(3 \times 40 \mathrm{~mL})$. The combined organic layers were washed with brine $(3 \times)$ and dried $\left(\mathrm{MgSO}_{4}\right)$. The solvent was removed under reduced pressure and the residue was taken directly to the next step without further purification.

The crude reaction mixture was then subjected to general procedure B. Recrystallization from $\mathrm{CH}_{2} \mathrm{Cl}_{2} /$ nhexane yielded the desired product as a white crystalline solid $(0.10 \mathrm{~g}, 10 \%$ yield over 2 steps $)$.

${ }^{1} \mathrm{H} \mathrm{NMR}\left(\mathrm{CDCl}_{3}, 400 \mathrm{MHz}\right): \delta=7.20-7.10(\mathrm{~m}, 3 \mathrm{H}), 7.03(\mathrm{~s}, 2 \mathrm{H}), 6.31(\mathrm{~d}, J=1.3 \mathrm{~Hz}, 1 \mathrm{H}), 5.23(\mathrm{~d}, J=1.2 \mathrm{~Hz}, 1 \mathrm{H})$, $2.31(\mathrm{~s}, 3 \mathrm{H}), 2.06(\mathrm{~s}, 3 \mathrm{H})$.

${ }^{13} \mathrm{C} \mathrm{NMR}\left(\mathrm{CDCl}_{3}, 100 \mathrm{MHz}\right): \delta=147.2,138.8,138.7,137.5,135.0,130.0,127.7,125.8,122.9,116.4,20.5,16.5$.

\section{Synthesis of 4-(1-phenylvinyl)benzonitrile (8a)}<smiles>C=C(Br)c1ccccc1</smiles><smiles>N#Cc1ccc(Br)cc1</smiles>

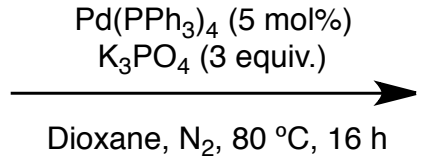<smiles>C=C(c1ccccc1)c1ccc(C#N)cc1</smiles>

A Schlenk tube was charged with 4-cyanophenylboronic acid (5.2 mmol, 1.3 equiv), $\mathrm{K}_{3} \mathrm{PO}_{4}(12 \mathrm{~mol}, 3.0$ equiv.) and $\mathrm{Pd}\left(\mathrm{PPh}_{3}\right)_{4}(0.2 \mathrm{mmol}, 5.0 \mathrm{~mol} \%)$. The flask was evacuated and backfilled with nitrogen 3 times. 1,4-Dioxane (50 $\mathrm{mL})$, and -bromo styrene $\left(4.0 \mathrm{mmol}, 1.0\right.$ equiv.) were added, and the reaction mixture was stirred at $80{ }^{\circ} \mathrm{C}$ overnight. It was cooled to room temperature and filtered through a plug of Celite with dichloromethane. The filtrate was concentrated under reduced pressure and the residue was purified by flash chromatography on silica, eluting with $8 \% \mathrm{EtOAc/hexane}$ to give the title product as a dark orange oil $(432.5 \mathrm{mg}, 53 \%$ yield.

${ }^{1} \mathrm{H} \mathrm{NMR}\left(\mathrm{CDCl}_{3}, 400 \mathrm{MHz}\right): \delta=7.63(\mathrm{~d}, J=8.6 \mathrm{~Hz}, 2 \mathrm{H}), 7.44(\mathrm{~d}, J=8.6 \mathrm{~Hz}, 2 \mathrm{H}), 7.38-7.27(\mathrm{~m}, 5 \mathrm{H}), 5.59(\mathrm{~d}, J=$ $0.7 \mathrm{~Hz}, 1 \mathrm{H}), 5.55(\mathrm{~d}, J=0.7 \mathrm{~Hz}, 1 \mathrm{H})$.

${ }^{13} \mathrm{C} \mathrm{NMR}\left(\mathrm{CDCl}_{3}, 100 \mathrm{MHz}\right): \delta=148.8,146.2,140.3,132.2,129.0,128.6,128.4,128.3,119.0,116.9,111.5$.

Data matched that reported in the literature. ${ }^{15}$

\section{Synthesis of methyl 4-(1-phenylvinyl)benzoate (9a) ${ }^{26}$}<smiles>C#Cc1ccccc1</smiles>

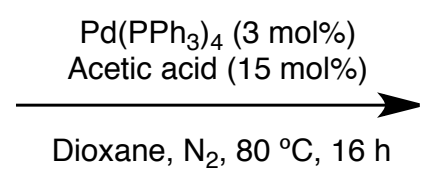<smiles>C=C(c1ccccc1)c1ccc(C(=O)OC)cc1</smiles>

$\mathrm{Pd}\left(\mathrm{PPh}_{3}\right)_{4}(0.12 \mathrm{mmol}, 3.0 \mathrm{~mol} \%)$ and (4-(methoxycarbonyl)phenyl)boronic acid $(6.0 \mathrm{mmol}, 1.5$ equiv.) were added an oven dried Schlenk tube. The flask was evacuated and backfilled with nitrogen 3 times and left under positive nitrogen pressure. Dry, degassed dioxane $(10 \mathrm{~mL})$ was added, followed by phenylacetylene $(4.0 \mathrm{mmol}, 1.0 \mathrm{equiv}$.) and acetic acid $(0.6 \mathrm{mmol}, 15 \mathrm{~mol} \%)$. The reaction mixture was stirred at $80{ }^{\circ} \mathrm{C}$ for 16 hours under positive nitrogen pressure. It was cooled to room temperature, diluted with $\mathrm{Et}_{2} \mathrm{O}$ and filtered through a plug of Celite with $\mathrm{Et}_{2} \mathrm{O}$. $\mathrm{The}$ filtrate was concentrated under reduced pressure, and the residue was purified by flash chromatography on silica eluting with $100 \%$ dichloromethane to give the desired product as a crystalline white solid. $(0.56 \mathrm{~g}, 59 \%$ yield). 
${ }^{1} \mathrm{H} \mathrm{NMR}\left(\mathrm{CDCl}_{3}, 400 \mathrm{MHz}\right): \delta=8.01(\mathrm{~d}, J=8.6 \mathrm{~Hz}, 2 \mathrm{H}), 7.41(\mathrm{~d}, J=8.6 \mathrm{~Hz}, 2 \mathrm{H}), 7.37-7.30(\mathrm{~m}, 5 \mathrm{H}), 5.55(\mathrm{~d}, J=$ $1.0 \mathrm{~Hz}, 1 \mathrm{H}), 5.54(\mathrm{~d}, J=1.0 \mathrm{~Hz}, 1 \mathrm{H}), 3.93(\mathrm{~s}, 3 \mathrm{H})$.

${ }^{13} \mathrm{C} \mathrm{NMR}\left(\mathrm{CDCl}_{3}, 100 \mathrm{MHz}\right): \delta=167.0,149.4,146.2,140.9,129.6,129.4,128.4,128.35,128.33,128.1,116.0$, 52.2 .

Data matched that reported in the literature. ${ }^{16}$

\section{General procedure for the photoredox catalyzed hydrogenation reaction}

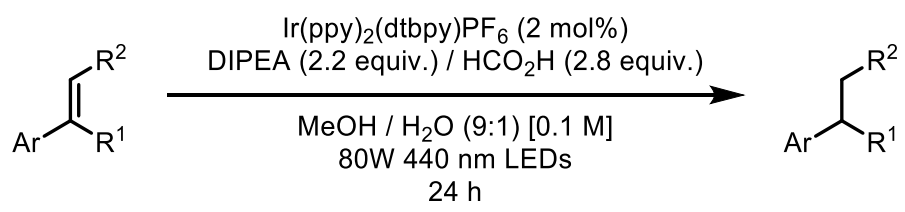

Alkene $(0.1 \mathrm{mmol}, 1.0$ equiv. ) and photocatalyst $(0.002 \mathrm{mmol}, 2 \mathrm{~mol} \%)$ were placed in a pressure relief sample vial and taken up in 9:1 methanol / water $(1 \mathrm{~mL})$. The reaction mixture was sparged with $\mathrm{N}_{2}$ for 1 minute. N,NDiisopropylethylamine ( $0.22 \mathrm{mmol}, 2.2$ equiv.) and formic acid ( $0.28 \mathrm{mmol}, 2.8$ equiv.) were added via an air tight syringe under a positive pressure of nitrogen, and the solution was sparged with $\mathrm{N}_{2}$ for 30 seconds. The cap was wrapped in parafilm and the reaction mixture was stirred for 24 hours at room temperature, whilst being irradiated with $80 \mathrm{~W}$ blue LEDs. The reaction mixture was diluted with $\mathrm{CH}_{2} \mathrm{Cl}_{2}$ and washed with saturated aqueous $\mathrm{NaHCO}_{3}$ solution $(1 \times 10 \mathrm{~mL})$. The aqueous layer was extracted with $\mathrm{CH}_{2} \mathrm{Cl}_{2}(2 \times 10 \mathrm{~mL})$ and the combined organic extracts were dried with $\mathrm{MgSO}_{4}$. The solvent was removed under reduced pressure and the residue purified by preparative TLC eluting with 1 - 5\% EtOAc/nhexane to yield the desired product.

\section{Product Characterisation Data}<smiles>CC(c1ccccc1)c1ccccc1</smiles>

Ethane-1,1-diyldibenzene (2): preparative TLC eluting with 5\% EtOAc/nhexane afforded the desired product as a colourless liquid (14.6 $\mathrm{mg}, 80 \%$ yield).

${ }^{1} \mathrm{H}$ NMR $\left(\mathrm{CDCl}_{3}, 400 \mathrm{MHz}\right): \delta=7.33-7.18(\mathrm{~m}, 10 \mathrm{H}), 4.18(\mathrm{q}, J=7.2 \mathrm{~Hz}, 1 \mathrm{H}), 1.67(\mathrm{~d}, J=7.2 \mathrm{~Hz}, 3 \mathrm{H})$.

${ }^{13} \mathrm{C} \mathrm{NMR}\left(\mathrm{CDCl}_{3}, 100 \mathrm{MHz}\right): \delta=146.5,128.5,127.8,126.1,44.9,22.0$.

Data matched that reported in the literature. ${ }^{27}$ 
<smiles>CC(C)N(C(C)C)C(C)CC(c1ccccc1)c1ccccc1</smiles>

\section{$N, N$-Diisopropyl-4,4-diphenylbutan-2-amine (3)}

${ }^{1} \mathrm{H}$ NMR $\left(400 \mathrm{MHz}, \mathrm{CDCl}_{3}\right): \delta=7.32-7.11(\mathrm{~m}, 10 \mathrm{H}), 4.15(\mathrm{dd}, J=9.0,6.0 \mathrm{~Hz}, 1 \mathrm{H}), 3.21-3.07(\mathrm{~m}, 2 \mathrm{H}), 2.78(\mathrm{dq}$, $J=12.9,6.5 \mathrm{~Hz}, 1 \mathrm{H}), 2.12-1.93(\mathrm{~m}, 2 \mathrm{H}), 1.05(\mathrm{~d}, J=6.6 \mathrm{~Hz}, 3 \mathrm{H}), 0.95(\mathrm{~d}, J=6.6 \mathrm{~Hz}, 6 \mathrm{H}), 0.92(\mathrm{~d}, J=6.7 \mathrm{~Hz}$, $6 \mathrm{H})$.

${ }^{13} \mathrm{C}$ NMR $\left(101 \mathrm{MHz}, \mathrm{CDCl}_{3}\right): \delta=146.90,144.68,128.49,128.46,128.37,127.99,126.02,125.88,48.38,47.17$, $44.43,42.78,29.85,24.41,22.38,21.03$.<smiles>CC(c1ccccc1)c1ccc(F)cc1</smiles>

1-Fluoro-4-(1-phenylethyl)benzene (4): preparative TLC eluting with 5\% EtOAc/nhexane afforded the desired product as a colourless liquid $(13.5 \mathrm{mg}, 68 \%$ yield).

${ }^{1} \mathrm{H} \mathrm{NMR}\left(\mathrm{CDCl}_{3}, 400 \mathrm{MHz}\right): \delta=7.32-7.28(\mathrm{~m}, 2 \mathrm{H}), 7.22-7.16(\mathrm{~m}, 5 \mathrm{H}), 7.00-6.94(\mathrm{~m}, 2 \mathrm{H}), 4.15(\mathrm{q}, \mathrm{J}=7.2 \mathrm{~Hz}, 1 \mathrm{H})$, $1.63(\mathrm{~d}, \mathrm{~J}=7.2 \mathrm{~Hz}, 3 \mathrm{H})$.

${ }^{13} \mathrm{C} \mathrm{NMR}\left(\mathrm{CDCl}_{3}, 100 \mathrm{MHz}\right): \delta=161.5\left(\mathrm{~d}, J_{\mathrm{C}-\mathrm{F}}=243.8 \mathrm{~Hz}\right), 146.30,142.2\left(\mathrm{~d}, J_{\mathrm{C}-\mathrm{F}}=3.2 \mathrm{~Hz}\right), 129.1\left(\mathrm{~d}, J_{\mathrm{C}-\mathrm{F}}=7.8\right.$ $\mathrm{Hz}), 128.6,127.7,126.3,115.2\left(\mathrm{~d}, J_{\mathrm{C}-\mathrm{F}}=21.1 \mathrm{~Hz}\right), 44.2,22.2$.

${ }^{19} \mathrm{~F}$ NMR $\left(376 \mathrm{MHz}, \mathrm{CDCl}_{3}\right): \delta=-117.5$.

Data matched that reported in the literature. ${ }^{27}$<smiles>CC(c1ccccc1)c1ccc(C(F)(F)F)cc1</smiles>

1-(1-Phenylethyl)-4-(trifluoromethyl)benzene (5): preparative TLC eluting with 5\% EtOAc/nhexane afforded the desired product as a colourless liquid $(55.9 \mathrm{~g}, 74 \%$ yield).

${ }^{1} \mathrm{H} \mathrm{NMR}\left(\mathrm{CDCl}_{3}, 400 \mathrm{MHz}\right): \delta=7.56(\mathrm{~d}, J=8.2 \mathrm{~Hz}, 2 \mathrm{H}), 7.36-7.31(\mathrm{~m}, 4 \mathrm{H}), 7.26-7.22(\mathrm{~m}, 3 \mathrm{H}), 4.23(\mathrm{q}, J=7.2 \mathrm{~Hz}$, $1 \mathrm{H}), 1.68(\mathrm{~d}, J=7.2 \mathrm{~Hz}, 3 \mathrm{H})$.

${ }^{13} \mathrm{C} \mathrm{NMR}\left(\mathrm{CDCl}_{3}, 100 \mathrm{MHz}\right): \delta=150.6,145.4,128.7,128.1,127.7,126.6,125.5\left(\mathrm{q}, J_{\mathrm{C}-\mathrm{F}}=3.4 \mathrm{~Hz}\right), 124.4\left(\mathrm{q}, J_{\mathrm{C}-\mathrm{F}}=\right.$ $270.3 \mathrm{~Hz}), 44.8,21.8$.

${ }^{19} \mathrm{~F}$ NMR $\left(376 \mathrm{MHz}, \mathrm{CDCl}_{3}\right): \delta=-62.4$.

Data matched that reported in the literature. ${ }^{28}$ 
10

1-Chloro-3-(1-phenylethyl)benzene (6): preparative TLC eluting with 5\% EtOAc/nhexane afforded the desired product as a colourless liquid $(52.8 \mathrm{mg}, 81 \%$ yield).

${ }^{1} \mathrm{H} \mathrm{NMR}\left(\mathrm{CDCl}_{3}, 400 \mathrm{MHz}\right): \delta=7.36-7.30(\mathrm{~m}, 2 \mathrm{H}), 7.27-7.18(\mathrm{~m}, 6 \mathrm{H}), 7.14-7.12(\mathrm{~m}, 1 \mathrm{H}), 4.16(\mathrm{q}, J=7.2 \mathrm{~Hz}, 1 \mathrm{H})$, $1.66(\mathrm{~d}, J=7.2 \mathrm{~Hz}, 3 \mathrm{H})$.

${ }^{13} \mathrm{C} \mathrm{NMR}\left(\mathrm{CDCl}_{3}, 100 \mathrm{MHz}\right): \delta=148.6,145.6,134.3,129.7,128.6,127.9,127.7,126.4,126.3,126.0,44.7,21.8$.

Data matched that reported in the literature. ${ }^{29}$<smiles>CC(c1ccccc1)c1ccc(Cl)cc1</smiles>

1-Chloro-4-(1-phenylethyl)benzene (7): preparative TLC eluting with 5\% EtOAc/nhexane afforded the desired product as a colourless liquid ( $16.3 \mathrm{mg}, 75 \%$ yield).

${ }^{1} \mathrm{H}$ NMR $\left(\mathrm{CDCl}_{3}, 600 \mathrm{MHz}\right): \delta=7.31-7.28(\mathrm{~m}, 2 \mathrm{H}), 7.26-7.24(\mathrm{~m}, 2 \mathrm{H}), 7.21-7.19(\mathrm{~m}, 3 \mathrm{H}), 7.16-7.14(\mathrm{~m}, 2 \mathrm{H}), 4.13$ (q, $J=7.2 \mathrm{~Hz}, 1 \mathrm{H}), 1.63(\mathrm{~d}, J=7.2 \mathrm{~Hz}, 3 \mathrm{H})$.

${ }^{13} \mathrm{C} \mathrm{NMR}\left(\mathrm{CDCl}_{3}, 151 \mathrm{MHz}\right): \delta=145.9,145.0,131.9,129.1,128.6,128.6,127.7,126.4,44.3,21.9$.

Data matched that reported in the literature. ${ }^{30}$<smiles>CC(c1ccccc1)c1ccc(C#N)cc1</smiles>

4-(1-Phenylethyl)benzonitrile (8): preparative TLC eluting with 15\% EtOAc/nhexane afforded the desired product as a colourless liquid ( $8.68 \mathrm{mg}, 42 \%$ yield).

${ }^{1} \mathrm{H} \mathrm{NMR}\left(\mathrm{CDCl}_{3}, 400 \mathrm{MHz}\right): \delta=7.57(\mathrm{~d}, J=8.4 \mathrm{~Hz}, 2 \mathrm{H}), 7.33-7.29(\mathrm{~m}, 4 \mathrm{H}), 7.23-7.17(\mathrm{~m}, 3 \mathrm{H}), 4.20(\mathrm{q}, J=7.2 \mathrm{~Hz}$, $1 \mathrm{H}), 1.65(\mathrm{~d}, J=7.2 \mathrm{~Hz}, 3 \mathrm{H})$.

${ }^{13} \mathrm{C} \mathrm{NMR}\left(\mathrm{CDCl}_{3}, 100 \mathrm{MHz}\right): \delta=152.0,144.8,132.4,128.8,128.6,127.7,126.8,119.2,110.0,45.0,21.6$.

Data matched that reported in the literature. ${ }^{31}$<smiles>COC(=O)c1ccc(C(C)c2ccccc2)cc1</smiles>

Methyl 4-(1-phenylethyl)benzoate (9): preparative TLC eluting with 50\% EtOAc/nhexane afforded the desired product as a colourless liquid ( $14.0 \mathrm{mg}, 58 \%$ yield) 
${ }^{1} \mathrm{H}$ NMR $\left(\mathrm{CDCl}_{3}, 600 \mathrm{MHz}\right): \delta=7.96(\mathrm{~d}, J=8.4 \mathrm{~Hz}, 2 \mathrm{H}), 7.31-7.28(\mathrm{~m}, 4 \mathrm{H}), 7.21-7.19(\mathrm{~m}, 3 \mathrm{H}), 4.21(\mathrm{q}, J=7.2 \mathrm{~Hz}$, $1 \mathrm{H}), 3.89(\mathrm{~s}, 3 \mathrm{H}), 1.66(\mathrm{~d}, J=7.2 \mathrm{~Hz}, 3 \mathrm{H})$.

${ }^{13} \mathrm{C} \mathrm{NMR}\left(\mathrm{CDCl}_{3}, 151 \mathrm{MHz}\right): \delta=167.2,151.9,145.6,129.9,128.6,128.2,127.8,127.7,126.5,52.1,45.0,21.7$.

Data matched that reported in the literature. ${ }^{32}$<smiles>CC(=O)Nc1ccc(C(C)c2ccccc2)cc1</smiles>

$N$-(4-(1-Phenylethyl)phenyl)acetamide (10): preparative TLC eluting with 30\% DCM/nhexane afforded the desired product as a pale orange solid $(16.5 \mathrm{mg}, 69 \%$ yield)

${ }^{1} \mathrm{H} \mathrm{NMR}\left(\mathrm{CDCl}_{3}, 600 \mathrm{MHz}\right): \delta=7.39(\mathrm{~d}, J=8.5 \mathrm{~Hz}, 2 \mathrm{H}), 7.29-7.26(\mathrm{~m}, 2 \mathrm{H}), 7.20-7.19(\mathrm{~m}, 4 \mathrm{H}), 7.16(\mathrm{~d}, J=8.5 \mathrm{~Hz}$, $2 \mathrm{H}), 4.12(\mathrm{q}, J=7.2 \mathrm{~Hz}, 1 \mathrm{H}), 2.15(\mathrm{~s}, 3 \mathrm{H}), 1.61(\mathrm{~d}, J=7.2 \mathrm{~Hz}, 3 \mathrm{H})$.

${ }^{13} \mathrm{C} \mathrm{NMR}\left(\mathrm{CDCl}_{3}, 151 \mathrm{MHz}\right): \delta=168.3,146.4,142.6,135.9,128.5,128.2,127.7,126.2,120.2,44.4,24.7,22.0$.

Data matched that reported in the literature. ${ }^{33}$<smiles>CC(c1ccccc1)c1ccccn1</smiles>

2-(1-Phenylethyl)pyridine (11): preparative TLC eluting with 20\% EtOAc/nhexane afforded the desired product as a colourless liquid $(12.5 \mathrm{mg}, 68 \%$ yield).

${ }^{1} \mathrm{H}$ NMR $\left(\mathrm{CDCl}_{3}, 400 \mathrm{MHz}\right): \delta=8.57-8.55(\mathrm{~m}, 1 \mathrm{H}), 7.56(\mathrm{td}, J=7.7,1.9 \mathrm{~Hz}, 1 \mathrm{H}), 7.31-7.29(\mathrm{~m}, 4 \mathrm{H}), 7.23-7.17(\mathrm{~m}$, $1 \mathrm{H}), 7.13-7.07(\mathrm{~m}, 2 \mathrm{H}), 4.30(\mathrm{q}, J=7.2 \mathrm{~Hz}, 1 \mathrm{H}), 1.71(\mathrm{~d}, J=7.2 \mathrm{~Hz}, 3 \mathrm{H})$.

${ }^{13} \mathrm{C} \mathrm{NMR}\left(\mathrm{CDCl}_{3}, 100 \mathrm{MHz}\right): \delta=165.2,149.3,145.2,136.5,128.6,127.8,126.4,122.3,121.3,47.5,20.9$.

Data matched that reported in the literature. ${ }^{34}$<smiles>Cc1ccccc1C(C)c1ccccc1</smiles>

1-Methyl-2-(1-phenylethyl)benzene (12): preparative TLC eluting with 5\% EtOAc/nhexane afforded the desired product as a colourless liquid $(42.6 \mathrm{mg}, 72 \%$ yield).

${ }^{1} \mathrm{H} \mathrm{NMR}\left(\mathrm{CDCl}_{3}, 400 \mathrm{MHz}\right): \delta=7.36-7.19(\mathrm{~m}, 9 \mathrm{H}), 4.39(\mathrm{q}, J=7.2 \mathrm{~Hz}, 1 \mathrm{H}), 2.30(\mathrm{~s}, 3 \mathrm{H}), 1.68(\mathrm{~d}, J=7.2 \mathrm{~Hz}, 3 \mathrm{H})$.

${ }^{13} \mathrm{C} \mathrm{NMR}\left(\mathrm{CDCl}_{3}, 100 \mathrm{MHz}\right): \delta=146.3,144.0,136.2,130.5,128.4,127.8,126.8,126.2,126.1,125.9,41.1,22.3$.

Data matched that reported in the literature. ${ }^{29}$ 
<smiles>Cc1cccc(C(C)c2ccccc2)c1</smiles>

1-Methyl-3-(1-phenylethyl)benzene (13): preparative TLC eluting with 5\% EtOAc/nhexane afforded the desired product as a colourless liquid $(53.3 \mathrm{~g}, 90 \%$ yield)

${ }^{1} \mathrm{H} \mathrm{NMR}\left(\mathrm{CDCl}_{3}, 400 \mathrm{MHz}\right): \delta=7.37-7.23(\mathrm{~m}, 6 \mathrm{H}), 7.11-7.06(\mathrm{~m}, 3 \mathrm{H}), 4.18(\mathrm{q}, J=7.2 \mathrm{~Hz}, 1 \mathrm{H}), 2.38(\mathrm{~s}, 3 \mathrm{H}), 1.70$ (d, $J=7.2 \mathrm{~Hz}, 3 \mathrm{H}$ ).

${ }^{13} \mathrm{C} \mathrm{NMR}\left(\mathrm{CDCl}_{3}, 100 \mathrm{MHz}\right): \delta=146.6,146.4,138.0,128.6,128.5,128.4,127.7,126.9,126.1,124.7,44.9,22.0$, 21.6.

Data matched that reported in the literature..$^{35}$<smiles>Cc1ccc(C(C)c2ccccc2)cc1</smiles>

1-Methyl-4-(1-phenylethyl)benzene (14): preparativeTLC eluting with 5\% EtOAc/nhexane afforded the desired product as a colourless liquid $(46.3 \mathrm{~g}, 79 \%$ yield).

${ }^{1} \mathrm{H} \mathrm{NMR}\left(\mathrm{CDCl}_{3}, 400 \mathrm{MHz}\right): \delta=7.36-7.14(\mathrm{~m}, 8 \mathrm{H}), 4.18(\mathrm{q}, J=7.2 \mathrm{~Hz}, 1 \mathrm{H}), 2.37(\mathrm{~s}, 3 \mathrm{H}), 1.69(\mathrm{~d}, J=7.2 \mathrm{~Hz}, 3 \mathrm{H})$.

${ }^{13} \mathrm{C} \mathrm{NMR}\left(\mathrm{CDCl}_{3}, 100 \mathrm{MHz}\right): \delta=146.7,143.5,135.6,129.2,128.5,127.7,127.6,126.1,44.5,22.1,21.1$.

Data matched that reported in the literature..$^{29}$<smiles>CC(c1ccccc1)c1ccc(Br)cc1</smiles>

11-(tert-Butyl)-4-(1-phenylethyl)benzene (15): preparative TLC eluting with 5\% EtOAc/nhexane afforded the desired product as a colourless liquid $(15.0 \mathrm{~g}, 63 \%$ yield $)$.

${ }^{1} \mathrm{H} \mathrm{NMR}\left(\mathrm{CDCl}_{3}, 400 \mathrm{MHz}\right): \delta=7.32-7.23(\mathrm{~m}, 6 \mathrm{H}), 7.21-7.15(\mathrm{~m}, 3 \mathrm{H}), 4.13(\mathrm{q}, J=7.2 \mathrm{~Hz}, 1 \mathrm{H}), 1.64(\mathrm{~d}, J=7.2 \mathrm{~Hz}$, $3 \mathrm{H}), 1.31(\mathrm{~s}, 9 \mathrm{H})$.

${ }^{13} \mathrm{C} \mathrm{NMR}\left(\mathrm{CDCl}_{3}, 100 \mathrm{MHz}\right): \delta=148.8,146.7,143.4,128.5,127.8,127.3,126.1,125.4,44.5,34.5,31.5,22.1$.

Data matched that reported in the literature. ${ }^{31}$<smiles>COc1ccc(C(C)c2ccccc2)cc1</smiles>

1-Methoxy-4-(1-phenylethyl)benzene (16): preparative TLC eluting with 5\% EtOAc/nhexane afforded the desired product as a colourless liquid $(18.1 \mathrm{~g}, 67 \%$ yield)

${ }^{1} \mathrm{H} \mathrm{NMR}\left(\mathrm{CDCl}_{3}, 400 \mathrm{MHz}\right): \delta=7.33-7.29(\mathrm{~m}, 2 \mathrm{H}), 7.26-7.21(\mathrm{~m}, 3 \mathrm{H}), 7.18(\mathrm{~d}, J=8.2 \mathrm{~Hz}, 2 \mathrm{H}), 6.86(\mathrm{~d}, J=8.2 \mathrm{~Hz}$, $2 \mathrm{H}), 4.14(\mathrm{q}, J=7.1 \mathrm{~Hz}, 1 \mathrm{H}), 3.80(\mathrm{~s}, 3 \mathrm{H}), 1.65(\mathrm{~d}, J=7.2 \mathrm{~Hz}, 3 \mathrm{H})$. 
${ }^{13} \mathrm{C} \mathrm{NMR}\left(\mathrm{CDCl}_{3}, 100 \mathrm{MHz}\right): \delta=157.9,146.9,138.7,128.6,128.5,127.6,126.0,113.8,55.3,44.0,22.2,19.9$.

Data matched that reported in the literature. ${ }^{27}$<smiles>COc1ccc(C(C)c2ccccc2C)cc1</smiles>

1-(1-(4-Methoxyphenyl)ethyl)-2-methylbenzene (17): preparative TLC eluting with 5\% EtOAc/nhexane afforded the desired product as a colourless liquid (53.3 $\mathrm{mg}, 79 \%$ yield)

${ }^{1} \mathrm{H} \mathrm{NMR}\left(\mathrm{CDCl}_{3}, 400 \mathrm{MHz}\right): \delta=7.31-7.29(\mathrm{~m}, 1 \mathrm{H}), 7.25-7.20(\mathrm{~m}, 1 \mathrm{H}), 7.17-7.15(\mathrm{~m}, 2 \mathrm{H}), 7.12-7.10(\mathrm{~m}, 2 \mathrm{H}), 6.86-$ $6.83(\mathrm{~m}, 2 \mathrm{H}), 4.31(\mathrm{q}, J=7.2 \mathrm{~Hz}, 1 \mathrm{H}), 3.80(\mathrm{~s}, 3 \mathrm{H}), 2.28(\mathrm{~s}, 3 \mathrm{H}), 1.62(\mathrm{~d}, J=7.2 \mathrm{~Hz}, 3 \mathrm{H})$.

${ }^{13} \mathrm{C} \mathrm{NMR}\left(\mathrm{CDCl}_{3}, 100 \mathrm{MHz}\right): \delta=157.8,144.4,138.5,136.1,130.5,128.7(2 \mathrm{C}), 126.6,126.1,113.8,55.3,40.2$, $22.4,19.8$.

Data matched that reported in the literature. ${ }^{36}$<smiles>COc1ccc(C(C)c2cc(OC)c(OC)c(OC)c2)cc1</smiles>

1,2,3-Trimethoxy-5-(1-(4-methoxyphenyl)ethyl)benzene (19): preparative TLC eluting with 50\% EtOAc/nhexane afforded the desired product as a colourless liquid (14.2 $\mathrm{mg}, 47 \%$ yield).

${ }^{1} \mathrm{H} \mathrm{NMR}\left(\mathrm{CDCl}_{3}, 600 \mathrm{MHz}\right): \delta=7.14(\mathrm{~d}, J=8.2 \mathrm{~Hz}, 2 \mathrm{H}), 6.84(\mathrm{~d}, J=8.2 \mathrm{~Hz}, 2 \mathrm{H}), 6.42(\mathrm{~s}, 2 \mathrm{H}), 4.04(\mathrm{q}, J=7.1 \mathrm{~Hz}$, $1 \mathrm{H}), 3.81(\mathrm{~s}, 9 \mathrm{H}), 3.79(\mathrm{~s}, 3 \mathrm{H}), 1.60(\mathrm{~d}, J=7.1 \mathrm{~Hz}, 3 \mathrm{H})$.

${ }^{13} \mathrm{C} \mathrm{NMR}\left(\mathrm{CDCl}_{3}, 151 \mathrm{MHz}\right): \delta=158.0,153.2,142.6,138.5,136.3,128.5,113.8,104.7,61.0,56.2,55.4,44.3,22.4$. Data matched that reported in the literature. ${ }^{37}$<smiles>CCC(c1ccccc1)c1ccccc1</smiles>

Propane-1,1-diyldibenzene (20): preparative TLC eluting with $8 \%$ toluene/nhexane afforded the desired product as a colourless oil $(16.5 \mathrm{mg}, 84 \%$ yield).

${ }^{1} \mathrm{H} \mathrm{NMR}\left(\mathrm{CDCl}_{3}, 400 \mathrm{MHz}\right): \delta=7.30-7.23(\mathrm{~m}, 8 \mathrm{H}), 7.19-7.15(\mathrm{~m}, 2 \mathrm{H}), 3.79(\mathrm{t}, J=7.6 \mathrm{~Hz}, 1 \mathrm{H}), 2.08$ (pent. $J=$ $7.6 \mathrm{~Hz}, 2 \mathrm{H}), 0.90(\mathrm{t}, J=7.6 \mathrm{~Hz}, 3 \mathrm{H})$.

${ }^{13} \mathrm{C} \mathrm{NMR}\left(\mathrm{CDCl}_{3}, 100 \mathrm{MHz}\right): \delta=145.3,128.5,128.1,126.1,53.4,28.7,12.9$.

Data matched that reported in the literature. ${ }^{38}$ 
<smiles>CC(c1ccccc1)C1CCCCC1</smiles>

(1-Cyclohexylethyl)benzene (21): preparative TLC eluting with 1\% EtOAc/nhexane afforded the desired product as a colourless oil ( $46 \mathrm{mg}, 80 \%$ yield).

${ }^{1} \mathrm{H} \mathrm{NMR}\left(\mathrm{CDCl}_{3}, 600 \mathrm{MHz}\right): \delta=7.31-7.28(\mathrm{~m}, 2 \mathrm{H}), 7.20-7.16(\mathrm{~m}, 3 \mathrm{H}), 2.46(\mathrm{~m}, 1 \mathrm{H}), 1.91-1.89(\mathrm{~m}, 1 \mathrm{H}), 1.78-1.75$ $(\mathrm{m}, 1 \mathrm{H}), 1.66-1.61(\mathrm{~m}, 2 \mathrm{H}), 1.47-1.39(\mathrm{~m}, 2 \mathrm{H}), 1.25(\mathrm{~d}, J=7.0 \mathrm{~Hz}, 3 \mathrm{H}), 1.16-1.10(\mathrm{~m}, 2 \mathrm{H}), 0.99-0.93(\mathrm{~m}, 1 \mathrm{H}), 0.86-$ $0.80(\mathrm{~m}, 1 \mathrm{H})$.

${ }^{13} \mathrm{C} \mathrm{NMR}\left(\mathrm{CDCl}_{3}, 151 \mathrm{MHz}\right): \delta=147.2,128.1,127.8,125.8,46.1,44.4,31.6,30.8,26.7,19.0$.

Data matched that reported in the literature. ${ }^{39}$<smiles>CC1CCCc2ccccc21</smiles>

1-Methylene-1,2,3,4-tetrahydronaphthalene (22): preparative TLC eluting with 1\% EtOAc/nhexane afforded the desired product as a colourless liquid $(27.2 \mathrm{mg}, 62 \%$ yield).

${ }^{1} \mathrm{H} \mathrm{NMR}\left(\mathrm{CDCl}_{3}, 600 \mathrm{MHz}\right): \delta=7.22-7.06(\mathrm{~m}, 4 \mathrm{H}), 2.94-2.90(\mathrm{~m}, 1 \mathrm{H}), 2.82-2.73(\mathrm{~m}, 2 \mathrm{H}), 1.96-1.83(\mathrm{~m}, 2 \mathrm{H}), 1.77-$ $1.71(\mathrm{~m}, 1 \mathrm{H}), 1.57-1.55(\mathrm{~m}, 1 \mathrm{H}), 1.31(\mathrm{~d}, J=7.0 \mathrm{~Hz}, 3 \mathrm{H})$.

${ }^{13} \mathrm{C} \mathrm{NMR}\left(\mathrm{CDCl}_{3}, 151 \mathrm{MHz}\right): \delta=142.3,137.0,129.1,128.2,125.7,125.5,32.6,31.6,30.1,23.0,20.6$.

Data matched that reported in the literature. ${ }^{40}$<smiles>CC(c1ccccc1)C1CCC1</smiles>

(1-Cyclobutylethyl)benzene (23): preparative TLC eluting with 1\% EtOAc/nhexane afforded the desired product as a colourless liquid $(39.6 \mathrm{mg}, 82 \%$ yield)

${ }^{1} \mathrm{H} \mathrm{NMR}\left(\mathrm{CDCl}_{3}, 400 \mathrm{MHz}\right): \delta=7.33-7.28(\mathrm{~m}, 2 \mathrm{H}), 7.21-7.17(\mathrm{~m}, 3 \mathrm{H}), 2.63(\mathrm{dq}, J=10.0,6.9 \mathrm{~Hz}, 1 \mathrm{H}), 2.48-2.42(\mathrm{~m}$, $1 \mathrm{H}), 2.17-2.11(\mathrm{~m}, 1 \mathrm{H}), 1.83-1.74(\mathrm{~m}, 4 \mathrm{H}), 1.67-1.60(\mathrm{~m}, 1 \mathrm{H}), 1.17(\mathrm{~d}, J=6.9 \mathrm{~Hz}, 3 \mathrm{H})$.

${ }^{13} \mathrm{C} \mathrm{NMR}\left(\mathrm{CDCl}_{3}, 100 \mathrm{MHz}\right): \delta=146.2,128.3,127.3,125.9,46.9,42.9,27.7,27.3,19.2,17.6$.<smiles>CC(c1ccccc1)C1CCCCCCC1</smiles>

(1-Phenylethyl)cyclooctane (24): preparative TLC eluting with 1\% EtOAc/nhexane afforded the desired product as a colourless liquid $(54.4 \mathrm{~g}, 84 \%$ yield).

${ }^{1} \mathrm{H} \mathrm{NMR}\left(\mathrm{CDCl}_{3}, 400 \mathrm{MHz}\right): \delta=7.32-7.28(\mathrm{~m}, 2 \mathrm{H}), 7.21-7.17(\mathrm{~m}, 3 \mathrm{H}), 2.60-2.53(\mathrm{~m}, 1 \mathrm{H}), 1.79-1.15(\mathrm{~m}, 15 \mathrm{H})$, overlapping with $1.25(\mathrm{~d}, J=7.0 \mathrm{~Hz}, 3 \mathrm{H})$.

${ }^{13} \mathrm{C} \mathrm{NMR}\left(\mathrm{CDCl}_{3}, 100 \mathrm{MHz}\right): \delta=147.6,128.2,127.8,125.7,46.3,43.3,31.1,29.5,27.3,27.3,26.7,26.2,25.7$, 19.1. 
<smiles>CCCC(C)c1ccccc1</smiles>

Pentan-2-ylbenzene (25): preparative TLC eluting with 1\% EtOAc/nhexane afforded the desired product as a volatile colourless liquid.

${ }^{1} \mathrm{H}$ NMR $\left(\mathrm{CDCl}_{3}, 400 \mathrm{MHz}\right): \delta=7.32-7.29(\mathrm{~m}, 2 \mathrm{H}), 7.21-7.18(\mathrm{~m}, 3 \mathrm{H}), 2.76-2.67(\mathrm{~m}, 1 \mathrm{H}), 1.64-1.50(\mathrm{~m}, 2 \mathrm{H}), 1.32-$ $1.20(\mathrm{~m}, 5 \mathrm{H}), 0.89(\mathrm{t}, J=7.3 \mathrm{~Hz}, 3 \mathrm{H})$.

${ }^{13} \mathrm{C} \mathrm{NMR}\left(\mathrm{CDCl}_{3}, 100 \mathrm{MHz}\right): \delta=148.1,128.4,127.1,125.9,40.9,39.8,22.4,21.0,14.3$.

Data matched that reported in the literature. ${ }^{41}$<smiles>CC(C)C(C)c1ccccc1</smiles>

(3-Methylbutan-2-yl)benzene (26): preparativeTLC eluting with 1\% EtOAc/nhexane afforded the desired product as a volatile colourless liquid.

${ }^{1} \mathrm{H} \mathrm{NMR}\left(\mathrm{CDCl}_{3}, 400 \mathrm{MHz}\right): \delta=7.32-7.27(\mathrm{~m}, 2 \mathrm{H}), 7.22-7.17(\mathrm{~m}, 3 \mathrm{H}), 2.48-2.41(\mathrm{~m}, 1 \mathrm{H}), 1.85-1.73(\mathrm{~m}, 1 \mathrm{H}), 1.26$ $(\mathrm{d}, J=7.0 \mathrm{~Hz}, 3 \mathrm{H}), 0.96(\mathrm{~d}, J=6.7 \mathrm{~Hz}, 3 \mathrm{H}), 0.78(\mathrm{~d}, J=6.7 \mathrm{~Hz}, 3 \mathrm{H})$.

${ }^{13} \mathrm{C} \mathrm{NMR}\left(\mathrm{CDCl}_{3}, 100 \mathrm{MHz}\right): \delta=147.2,128.2,127.8,125.8,47.0,34.6,21.3,20.3,18.9$.

Data matched that reported in the literature. ${ }^{40}$<smiles>CCCCCC(C)c1ccccc1</smiles>

Heptan-2-ylbenzene (27): preparative TLC eluting with $1 \%$ EtOAc/nhexane afforded the desired product as a colourless liquid (15.6 mg, 90\% yield).

${ }^{1} \mathrm{H}$ NMR $\left(\mathrm{CDCl}_{3}, 400 \mathrm{MHz}\right): \delta=7.36-7.30(\mathrm{~m}, 2 \mathrm{H}), 7.22-7.18(\mathrm{~m}, 3 \mathrm{H}), 2.74-2.66(\mathrm{~m}, 1 \mathrm{H}), 1.65-1.52(\mathrm{~m}, 2 \mathrm{H}), 1.31-$ $1.23(\mathrm{~m}, 9 \mathrm{H}), 0.90-0.86(\mathrm{~m}, 3 \mathrm{H})$.

${ }^{13} \mathrm{C} \mathrm{NMR}\left(\mathrm{CDCl}_{3}, 100 \mathrm{MHz}\right): \delta=148.1,148.1,128.4,128.4,127.1,127.1,125.9,125.9,40.1,40.1,38.6,38.6,32.1$, $32.1,27.6,27.6,22.8,22.8,22.5,22.5,14.2,14.2$.

Data matched that reported in the literature. ${ }^{42}$<smiles>CCC(C)c1ccc(Cl)c(Cl)c1</smiles>

4-(sec-Butyl)-1,2-dichlorobenzene (28): preparative TLC eluting with 1\% EtOAc/nhexane afforded the desired product as a colourless liquid $(43.0 \mathrm{mg}, 71 \%$ yield).

${ }^{1} \mathrm{H} \mathrm{NMR}\left(\mathrm{CDCl}_{3}, 600 \mathrm{MHz}\right): \delta=7.34(\mathrm{~d}, J=8.2 \mathrm{~Hz}, 1 \mathrm{H}), 7.26(\mathrm{~s}, 1 \mathrm{H}), 7.01(\mathrm{dd}, J=8.2,1.9 \mathrm{~Hz}, 1 \mathrm{H}), 2.59-2.54(\mathrm{~m}$, $1 \mathrm{H}), 1.62-1.51(\mathrm{~m}, 2 \mathrm{H}), 1.21(\mathrm{~d}, J=7.1 \mathrm{~Hz}, 3 \mathrm{H}), 0.83-0.81(\mathrm{~m}, 3 \mathrm{H})$. 
${ }^{13} \mathrm{C} \mathrm{NMR}\left(\mathrm{CDCl}_{3}, 151 \mathrm{MHz}\right): \delta=148.1,132.3,130.3,129.6,129.2,126.7,41.2,31.1,21.8,12.2$.<smiles>CC(COc1ccccc1)c1ccccc1</smiles>

(1-Phenoxypropan-2-yl)benzene (29): preparative TLC eluting with $10 \% \mathrm{CH}_{2} \mathrm{Cl}_{2} /$ nhexane afforded the desired product as a colourless liquid (14.2 $\mathrm{mg}, 67 \%$ yield)

${ }^{1} \mathrm{H} \mathrm{NMR}\left(\mathrm{CDCl}_{3}, 600 \mathrm{MHz}\right): \delta=7.35-7.25(\mathrm{~m}, 7 \mathrm{H}), 6.95-6.89(\mathrm{~m}, 3 \mathrm{H}), 4.11-4.09(\mathrm{~m}, 1 \mathrm{H}), 3.98-3.96(\mathrm{~m}, 1 \mathrm{H}), 3.28-$ $3.22(\mathrm{~m}, 1 \mathrm{H}), 1.43(\mathrm{~d}, J=7.0 \mathrm{~Hz}, 3 \mathrm{H})$.

${ }^{13} \mathrm{C} \mathrm{NMR}\left(\mathrm{CDCl}_{3}, 151 \mathrm{MHz}\right): \delta=159.1,143.8,129.5,128.6,127.6,126.7,120.8,114.8,73.5,39.7,18.3$.<smiles>COC(OC)(c1ccccc1)C(C)c1ccccc1</smiles>

(1,1-Dimethoxypropane-1,2-diyl)dibenzene (30): preparative TLC eluting with 10\% dichloromethane/nhexane afforded the desired product as a white solid (19.5 $\mathrm{mg}, 76 \%$ yield).

${ }^{1} \mathrm{H} \mathrm{NMR}\left(\mathrm{CDCl}_{3}, 600 \mathrm{MHz}\right): \delta=7.26-7.10(\mathrm{~m}, 6 \mathrm{H}), 6.97-6.96(\mathrm{~m}, 2 \mathrm{H}), 6.82-6.80(\mathrm{~m}, 2 \mathrm{H}), 3.53(\mathrm{q}, \mathrm{J}=7.3 \mathrm{~Hz}, 1 \mathrm{H})$, $3.42(\mathrm{~s}, 3 \mathrm{H}), 3.10(\mathrm{~s}, 3 \mathrm{H}), 1.16(\mathrm{~d}, J=7.3 \mathrm{~Hz}, 3 \mathrm{H})$.

${ }^{13} \mathrm{C} \mathrm{NMR}\left(\mathrm{CDCl}_{3}, 151 \mathrm{MHz}\right): \delta=141.5,137.1,130.1,129.0,127.7,127.1,126.9,126.3,105.7,49.6,48.5,44.5$, 15.3.<smiles>CCC(C)c1ccccc1F</smiles>

1-(sec-Butyl)-2-fluorobenzene (31): preparative TLC eluting with 1\% EtOAc/nhexane afforded the desired product as a volatile colourless liquid.

${ }^{1} \mathrm{H} \mathrm{NMR}\left(\mathrm{CDCl}_{3}, 400 \mathrm{MHz}\right): \delta=7.23-6.98(\mathrm{~m}, 4 \mathrm{H}), 3.04-2.95(\mathrm{~m}, 1 \mathrm{H}), 1.69-1.57(\mathrm{~m}, 2 \mathrm{H}), 1.25(\mathrm{~d}, \mathrm{~J}=7.0 \mathrm{~Hz}, 3 \mathrm{H})$, $0.85(\mathrm{t}, J=7.4 \mathrm{~Hz}, 3 \mathrm{H})$.

${ }^{13} \mathrm{C} \mathrm{NMR}\left(\mathrm{CDCl}_{3}, 126 \mathrm{MHz}\right): \delta=161.0(\mathrm{~d}, J=244.2 \mathrm{~Hz}), 134.2(\mathrm{~d}, J=14.7 \mathrm{~Hz}), 128.1(\mathrm{~d}, J=5.5 \mathrm{~Hz}), 127.2(\mathrm{~d}, J$ $=8.3 \mathrm{~Hz}), 124.1(\mathrm{~d}, J=3.5 \mathrm{~Hz}), 115.3(\mathrm{~d}, J=23.1 \mathrm{~Hz}), 34.3(\mathrm{~d}, J=1.6 \mathrm{~Hz}), 30.1,20.7,12.3$.

${ }^{19} \mathrm{~F} \mathrm{NMR}\left(376 \mathrm{MHz}, \mathrm{CDCl}_{3}\right): \delta=-119.2$.<smiles>CC(C)c1ccc2ccccc2c1</smiles>

2-Isopropylnaphthalene (32): preparative TLC eluting with 1\% EtOAc/nhexane afforded the desired product as a colourless liquid $(6.23 \mathrm{mg}, 37 \%$ yield $)$

${ }^{1} \mathrm{H} \mathrm{NMR}\left(\mathrm{CDCl}_{3}, 600 \mathrm{MHz}\right): \delta=7.81-1.78(\mathrm{~m}, 3 \mathrm{H}), 7.65(\mathrm{~s}, 1 \mathrm{H}), 7.46-7.39(\mathrm{~m}, 3 \mathrm{H}), 3.08($ septet, $\mathrm{J}=6.9 \mathrm{~Hz}, 1 \mathrm{H})$, $1.35(\mathrm{~d}, \mathrm{~J}=6.9 \mathrm{~Hz}, 6 \mathrm{H})$.

${ }^{13} \mathrm{C} \mathrm{NMR}\left(\mathrm{CDCl}_{3}, 151 \mathrm{MHz}\right): \delta=146.5,133.8,132.2,128.0,127.7,127.7,125.9,125.9,125.2,124.2,34.4,24.1$. 
Data matched that reported in the literature. ${ }^{43}$<smiles>CCc1cccc(Oc2ccc(OC)cc2)c1</smiles>

3-Ethyl-4'-methoxy-1,1'-biphenyl (33): preparative TLC eluting with 10\% EtOAc/nhexane afforded the desired product as a colourless liquid (14 $\mathrm{mg}, 67 \%$ yield).

${ }^{1} \mathrm{H} \mathrm{NMR}\left(\mathrm{CDCl}_{3}, 400 \mathrm{MHz}\right): \delta=7.22-7.18(\mathrm{~m}, 1 \mathrm{H}), 6.99-6.97(\mathrm{~m}, 2 \mathrm{H}), 6.89-6.87(\mathrm{~m}, 3 \mathrm{H}), 6.81(\mathrm{~m}, 1 \mathrm{H}), 6.75-$ $6.73(\mathrm{~m}, 1 \mathrm{H}), 3.81(\mathrm{~s}, 3 \mathrm{H}), 2.61(\mathrm{q}, J=7.6 \mathrm{~Hz}, 2 \mathrm{H}), 1.21(\mathrm{t}, J=7.6 \mathrm{~Hz}, 3 \mathrm{H})$.

${ }^{13} \mathrm{C} \mathrm{NMR}\left(\mathrm{CDCl}_{3}, 100 \mathrm{MHz}\right): \delta=158.6,155.9,150.4,146.4,129.5,129.4,122.2,120.9,117.3,114.9,55.8,28.9$, 15.6.

Data matched that reported in the literature. ${ }^{44}$<smiles>CCOc1ccc(CC)cc1</smiles>

1-Ethoxy-4-ethylbenzene (34): preparative TLC eluting with 8\% EtOAc/nhexane afforded the desired product as a colourless liquid.

${ }^{1} \mathrm{H} \mathrm{NMR}\left(\mathrm{CDCl}_{3}, 400 \mathrm{MHz}\right): \delta=7.10(\mathrm{~d}, J=8.4 \mathrm{~Hz}, 2 \mathrm{H}), 6.83(\mathrm{~d}, J=8.4 \mathrm{~Hz}, 2 \mathrm{H}), 4.01(\mathrm{q}, J=7.2 \mathrm{~Hz}, 2 \mathrm{H}), 2.59(\mathrm{q}$, $J=7.6 \mathrm{~Hz}, 2 \mathrm{H}), 1.40(\mathrm{t}, J=7.2 \mathrm{~Hz}, 3 \mathrm{H}), 1.21(\mathrm{t}, J=7.6 \mathrm{~Hz}, 3 \mathrm{H})$.

${ }^{13} \mathrm{C} \mathrm{NMR}\left(\mathrm{CDCl}_{3}, 100 \mathrm{MHz}\right): \delta=157.1,136.4,128.8,114.5,63.6,28.1,16.1,15.1$.

Data matched that reported in the literature. ${ }^{45}$<smiles>c1ccc(CCc2ccccc2)cc1</smiles>

1,2-Diphenylethane (35): preparative TLC eluting with $8 \%$ EtOAc/nhexane afforded the desired product as a colourless solid (16.9 $\mathrm{mg}, 93 \%$ yield).

${ }^{1} \mathrm{H}$ NMR $\left(400 \mathrm{MHz}, \mathrm{CDCl}_{3:}\right) \delta=7.33-7.27(\mathrm{~m}, 4 \mathrm{H}), 7.24-7.17(\mathrm{~m}, 6 \mathrm{H}), 2.94(\mathrm{~s}, 4 \mathrm{H})$.

${ }^{13} \mathrm{C}$ NMR $\left(100 \mathrm{MHz}, \mathrm{CDCl}_{3}\right): \delta=141.91,128.58,128.47,126.05,38.10$.

Data matched that reported in the literature. ${ }^{46}$<smiles>CCCc1ccc(OC)cc1</smiles>

1-Methoxy-4-propylbenzene (36): preparative TLC eluting with 3\% EtOAc/nhexane afforded the desired product as a colourless liquid.

${ }^{1} \mathrm{H} \mathrm{NMR}\left(\mathrm{CDCl}_{3}, 400 \mathrm{MHz}\right): \delta=7.10(\mathrm{~d}, J=8.0 \mathrm{~Hz}, 2 \mathrm{H}), 6.83(\mathrm{~d}, J=8.0 \mathrm{~Hz}, 2 \mathrm{H}), 3.79(\mathrm{~s}, 3 \mathrm{H}), 2.53(\mathrm{t}, J=7.6 \mathrm{~Hz}$, 2H), 1.61 (sept. $J=7.6 \mathrm{~Hz}, 2 \mathrm{H}), 0.93(\mathrm{t}, J=7.6 \mathrm{~Hz}, 3 \mathrm{H})$.

${ }^{13} \mathrm{C} \mathrm{NMR}\left(\mathrm{CDCl}_{3}, 100 \mathrm{MHz}\right): \delta=157.7,135.0,129.4,113.7,55.4,37.3,25.0,13.9$. 
Data matched that reported in the literature. ${ }^{47}$<smiles>CCOC(=O)CCCCc1ccc(OC)cc1</smiles>

Ethyl 5-(4-methoxyphenyl)pentanoate (37): preparative TLC eluting with 5\% EtOAc/nhexane afforded the desired product as a colourless liquid $(20 \mathrm{mg}, 87 \%$ yield).

${ }^{1} \mathrm{H} \mathrm{NMR}\left(\mathrm{CDCl}_{3}, 400 \mathrm{MHz}\right): \delta=7.11-7.08(\mathrm{~m}, 2 \mathrm{H}), 6.85-6.80(\mathrm{~m}, 2 \mathrm{H}), 4.12(\mathrm{q}, J=7.2 \mathrm{~Hz}, 2 \mathrm{H}), 3.78(\mathrm{~s}, 3 \mathrm{H})$, $2.59-2.55(\mathrm{~m}, 2 \mathrm{H}), 2.33-2.29(\mathrm{~m}, 2 \mathrm{H}), 1.65-1.60(\mathrm{~m}, 5 \mathrm{H}), 1.25(\mathrm{t}, J=7.2 \mathrm{~Hz}, 3 \mathrm{H})$.

${ }^{13} \mathrm{C} \mathrm{NMR}\left(\mathrm{CDCl}_{3}, 100 \mathrm{MHz}\right): \delta=173.8,157.8,134.4,129.4,113.8,60.4,55.4,34.8,34.3,31.3,24.7,14.4$.

Data matched that reported in the literature. ${ }^{48}$<smiles>CCCCc1ccc(OC)cc1</smiles>

1-Butyl-4-methoxybenzene (38): preparative TLC eluting with 5\% EtOAc/nhexane afforded the desired product as a colourless liquid (12 $\mathrm{mg}, 75 \%$ yield).

${ }^{1} \mathrm{H} \mathrm{NMR}\left(\mathrm{CDCl}_{3}, 400 \mathrm{MHz}\right): \delta=7.10(\mathrm{~d}, J=8.4 \mathrm{~Hz}, 2 \mathrm{H}), 6.83(\mathrm{~d}, J=8.4 \mathrm{~Hz}, 2 \mathrm{H}), 3.79(\mathrm{~s}, 3 \mathrm{H}), 2.57-2.54(\mathrm{~m}, 2 \mathrm{H})$, $1.61-1.53(\mathrm{~m}, 2 \mathrm{H}), 1.39-1.30(\mathrm{~m}, 2 \mathrm{H}), 0.94-0.91(\mathrm{~m}, 3 \mathrm{H})$.

${ }^{13} \mathrm{C} \mathrm{NMR}\left(\mathrm{CDCl}_{3}, 100 \mathrm{MHz}\right): \delta=157.7,135.2,129.4,113.7,55.4,34.9,34.1,22.5,14.1$.

Data matched that reported in the literature..$^{49}$

\section{Derivatisation of 1-(2-(1-(2,3-dimethylphenyl)ethyl)-1H-imidazol-1-yl)ethanone (18)}

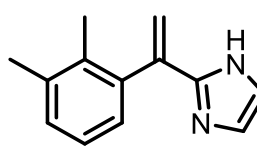

18

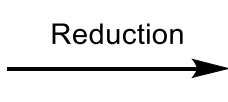<smiles>Cc1cccc(C(C)c2ncc[nH]2)c1C</smiles><smiles>CCC(=O)OC(C)=O</smiles><smiles>CC(=O)n1ccnc1C(C)c1cccc(C)c1C</smiles>

$18 a$

Olefin 18a was subjected to the general conditions for the photoredox-catalysed hydrogenation reaction. After work up, the crude reaction mixture was dissolved in dichloromethane $(3 \mathrm{~mL})$ and treated with acetic anhydride $(3 \mathrm{mmol}$, 10 equiv.), dropwise at room temperature. The reaction mixture was stirred at room temperature overnight. It was quenched with saturated aqueous $\mathrm{NaHCO}_{3}$ solution $(2 \mathrm{~mL})$ and extracted with dichloromethane $(2 \times 2 \mathrm{~mL})$. The combined organic extracts were dried with $\mathrm{MgSO}_{4}$ and the solvent was removed under reduced pressure. The residue was purified by preparative TLC eluting with $50 \%$ EtOAc/nhexane to yield the desired product as a white crystalline solid $(7.6 \mathrm{mg}, 38 \%$ yield over 2 steps).

${ }^{1} \mathrm{H}$ NMR $\left(\mathrm{CDCl}_{3}, 400 \mathrm{MHz}\right): \delta=7.23(\mathrm{~d}, J=1.8 \mathrm{~Hz}, 1 \mathrm{H}), 7.04(\mathrm{~d}, J=1.8 \mathrm{~Hz}, 1 \mathrm{H}), 6.99-6.90(\mathrm{~m}, 2 \mathrm{H}), 6.59-6.57(\mathrm{~m}$, $1 \mathrm{H}), 5.08(\mathrm{q}, J=7.1 \mathrm{~Hz}, 1 \mathrm{H}), 2.42(\mathrm{~s}, 3 \mathrm{H}), 2.36(\mathrm{~s}, 3 \mathrm{H}), 2.31(\mathrm{~s}, 3 \mathrm{H}), 1.61(\mathrm{~d}, J=7.1 \mathrm{~Hz}, 3 \mathrm{H})$.

${ }^{13} \mathrm{C} \mathrm{NMR}\left(\mathrm{CDCl}_{3}, 100 \mathrm{MHz}\right): \delta=158.0,153.1,142.6,138.4,136.2,128.5,113.8,104.6,60.9,56.2,55.3,44.3,22.3$. 
${ }^{1} \mathrm{H},{ }^{13} \mathrm{C}$ and ${ }^{19} \mathrm{~F}$ NMR Spectra

1-Fluoro-4-(1-phenylvinyl)benzene (4a) ${ }^{1} \mathrm{H} \mathrm{NMR}\left(\mathrm{CDCl}_{3}, 400 \mathrm{MHz}\right)$

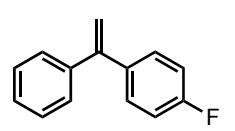

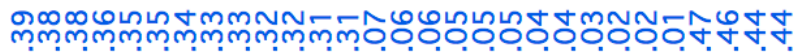

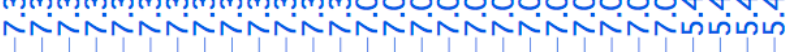
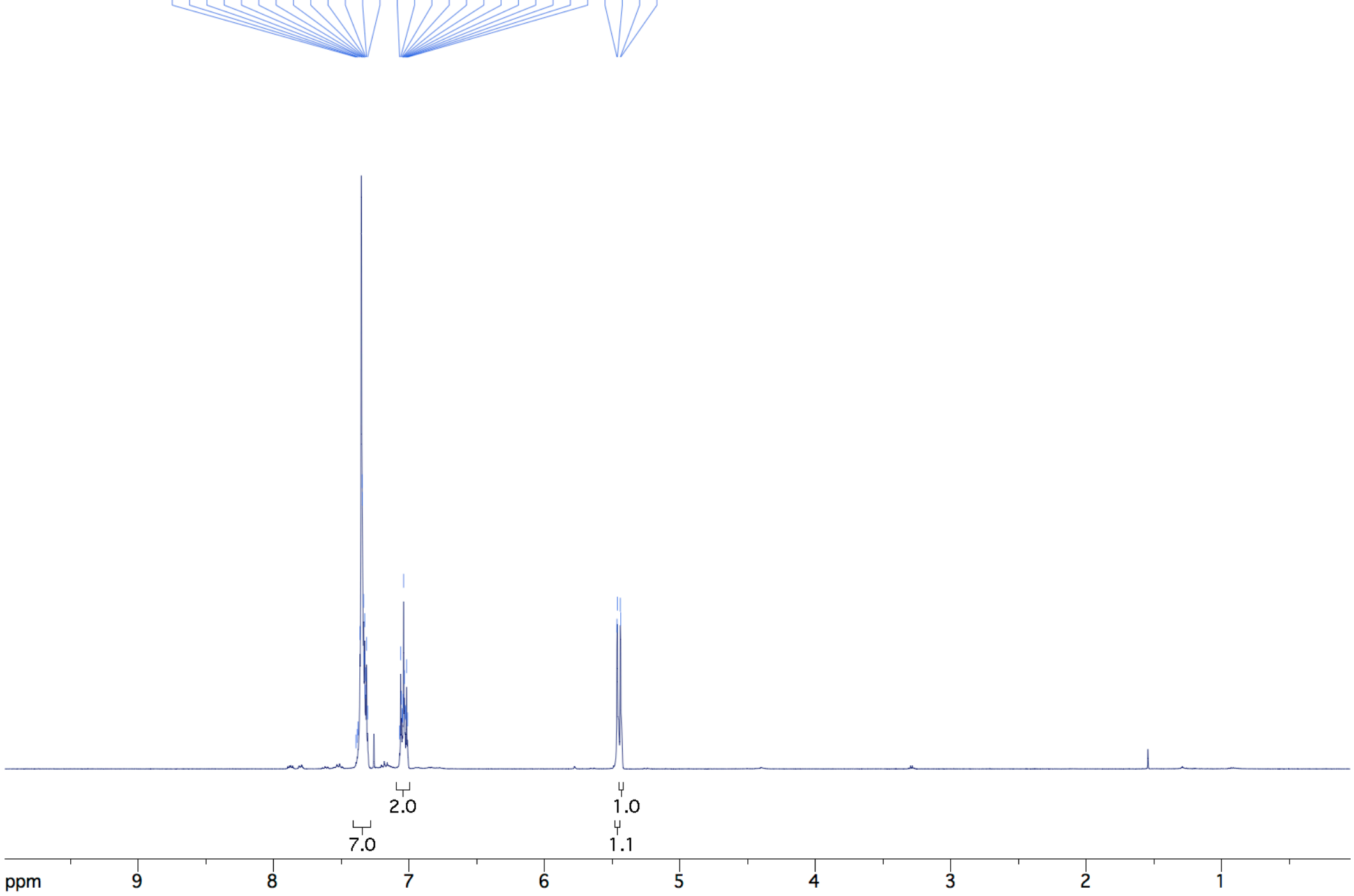
1-Fluoro-4-(1-phenylvinyl)benzene (4a) ${ }^{13} \mathrm{C} \mathrm{NMR}\left(\mathrm{CDCl}_{3}, 100 \mathrm{MHz}\right)$
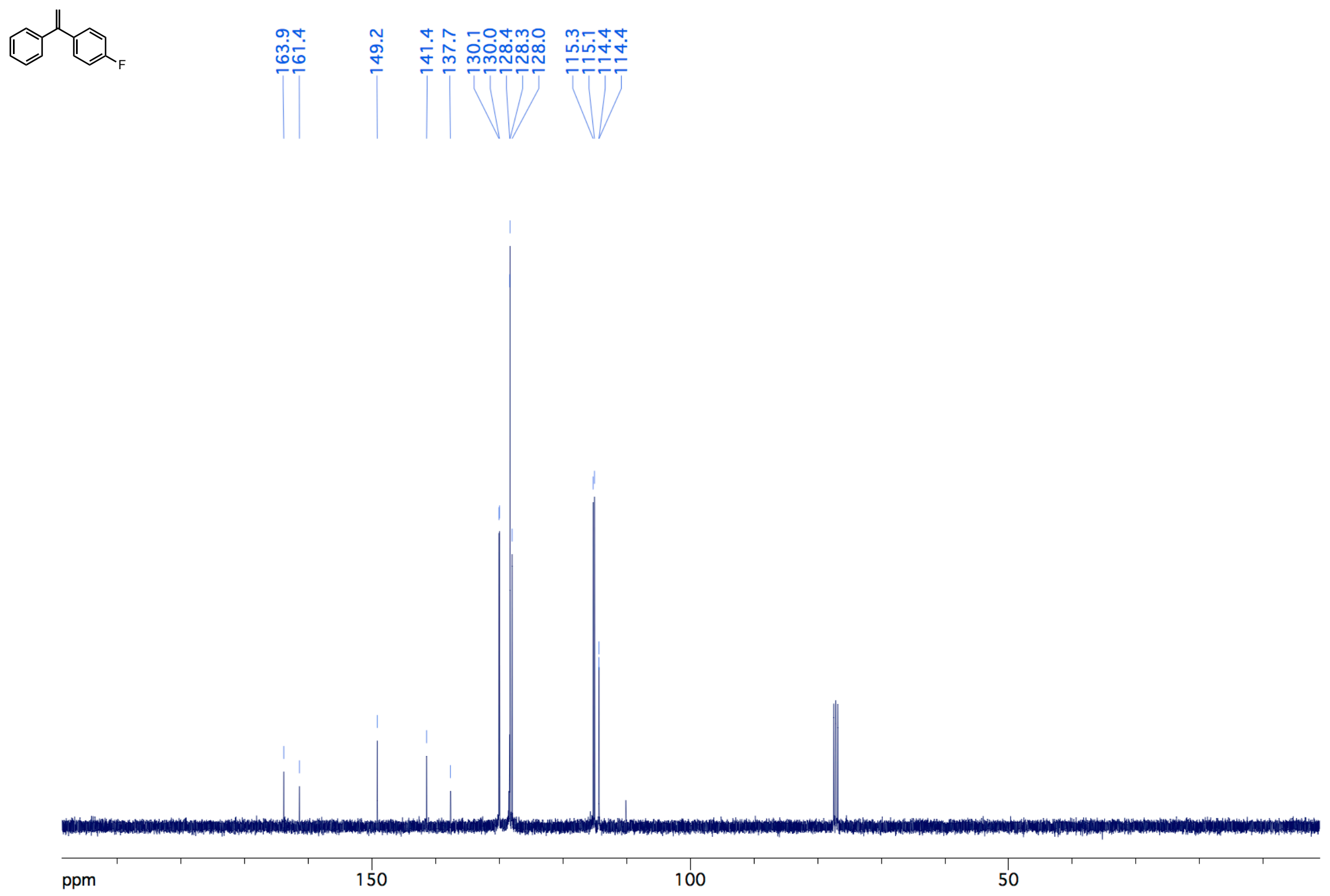
1-Fluoro-4-(1-phenylvinyl)benzene (4a) ${ }^{19} \mathrm{~F}-\mathrm{NMR}\left(\mathrm{CDCl}_{3}, 376 \mathrm{MHz}\right)$<smiles>C=C(c1ccccc1)c1ccc(F)cc1</smiles>

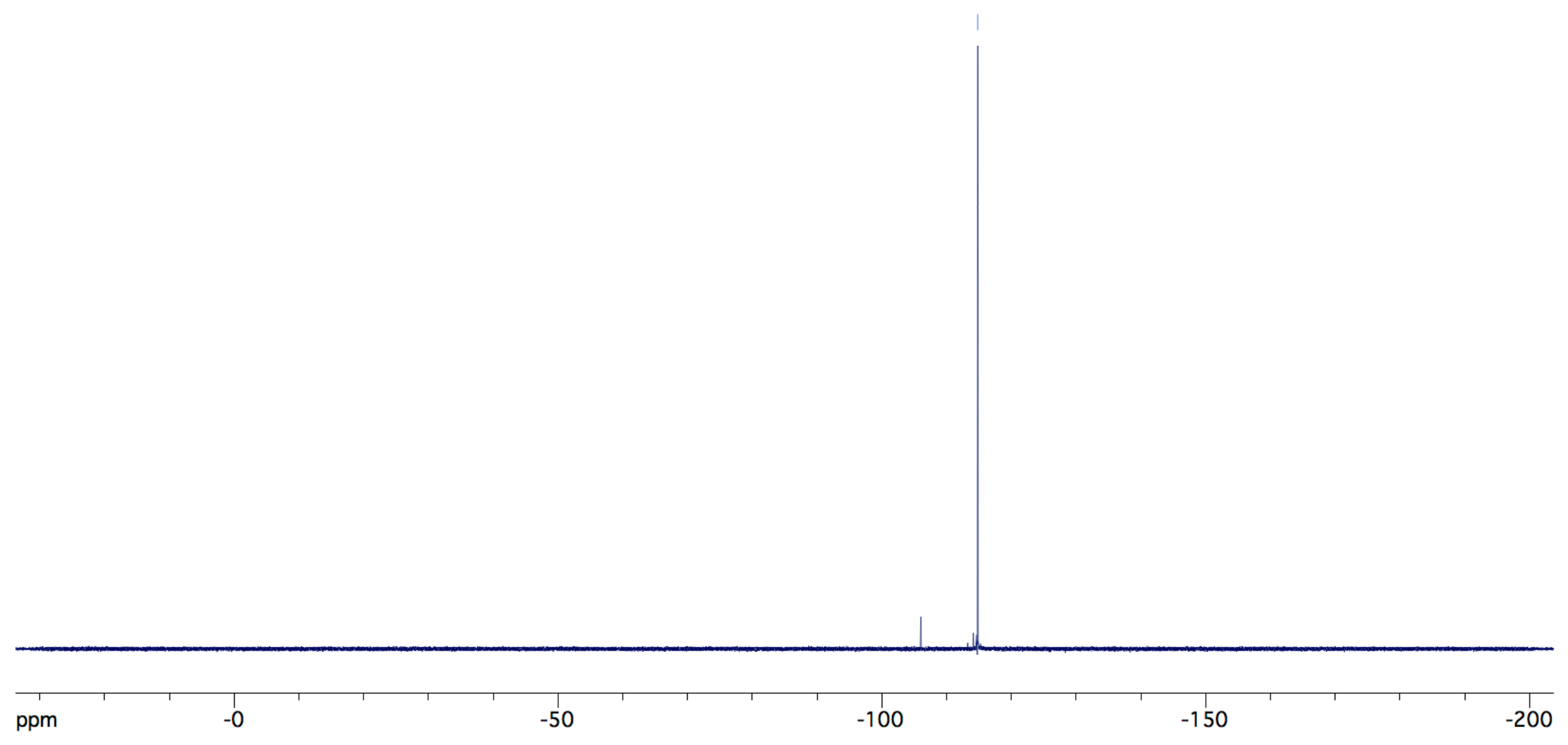




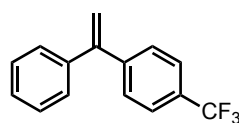

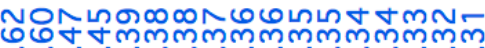

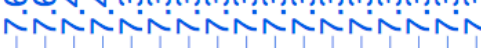

ભpomm

กเกเก

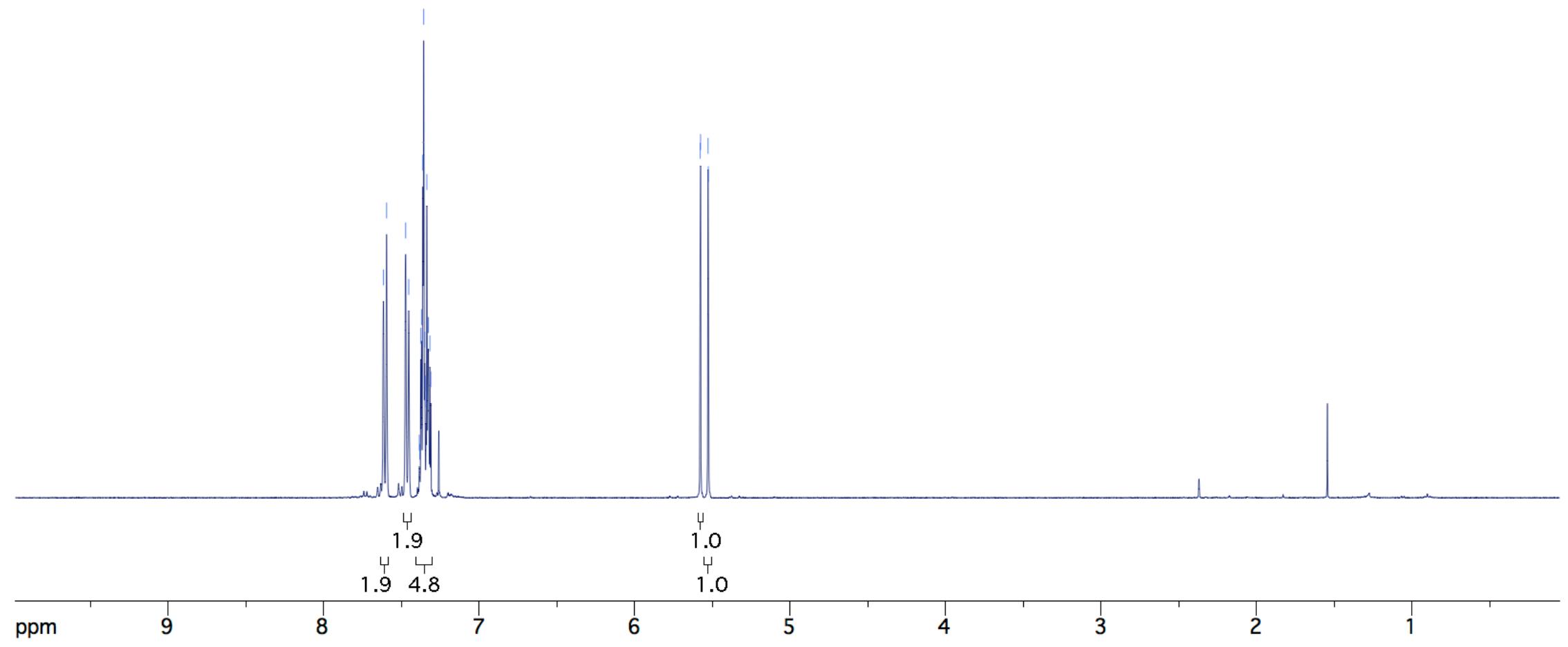


<smiles>C=C(c1ccccc1)c1ccc(C(F)(F)F)cc1</smiles>

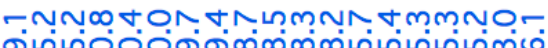

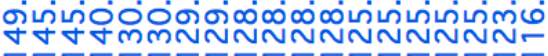
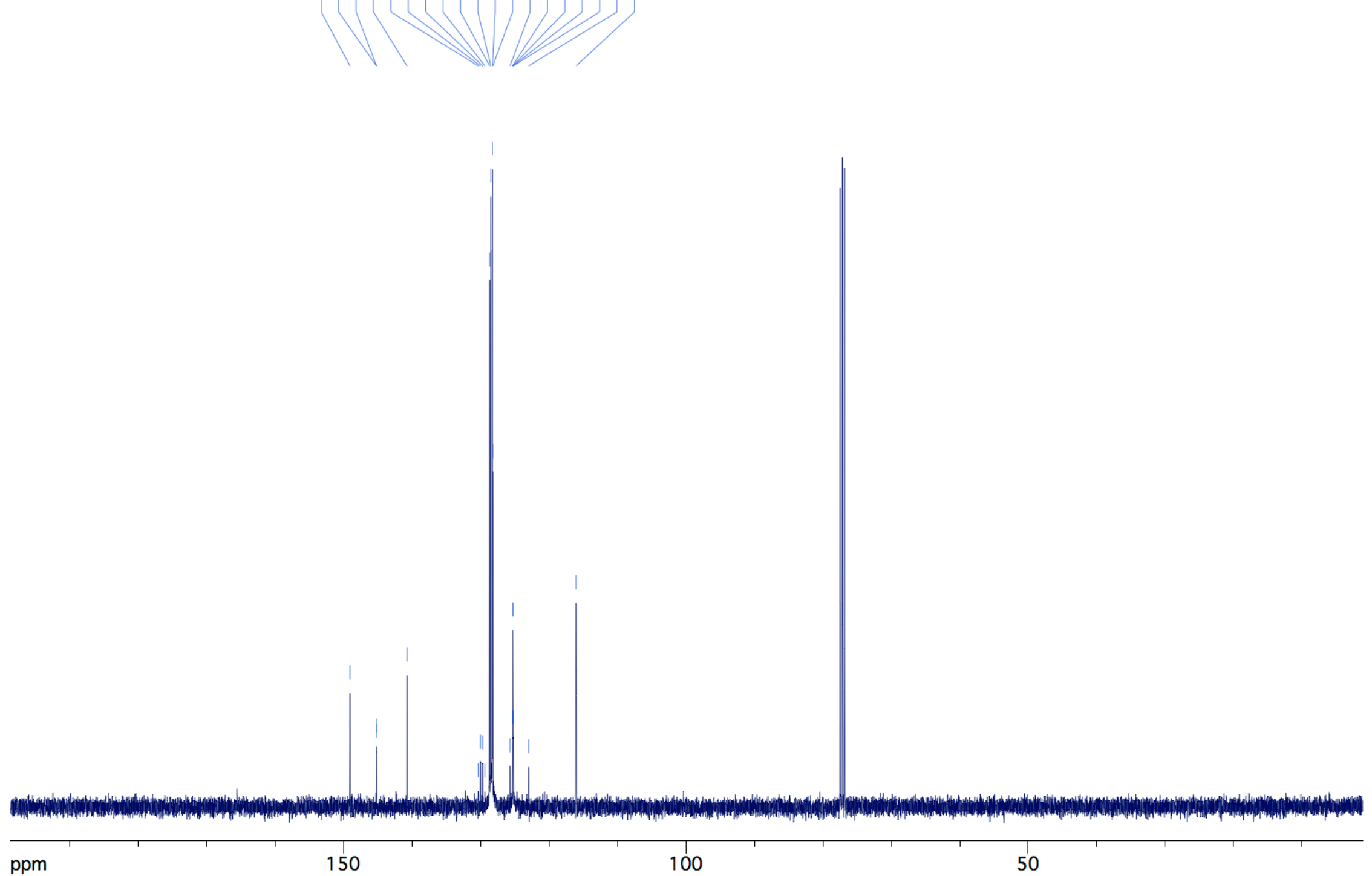

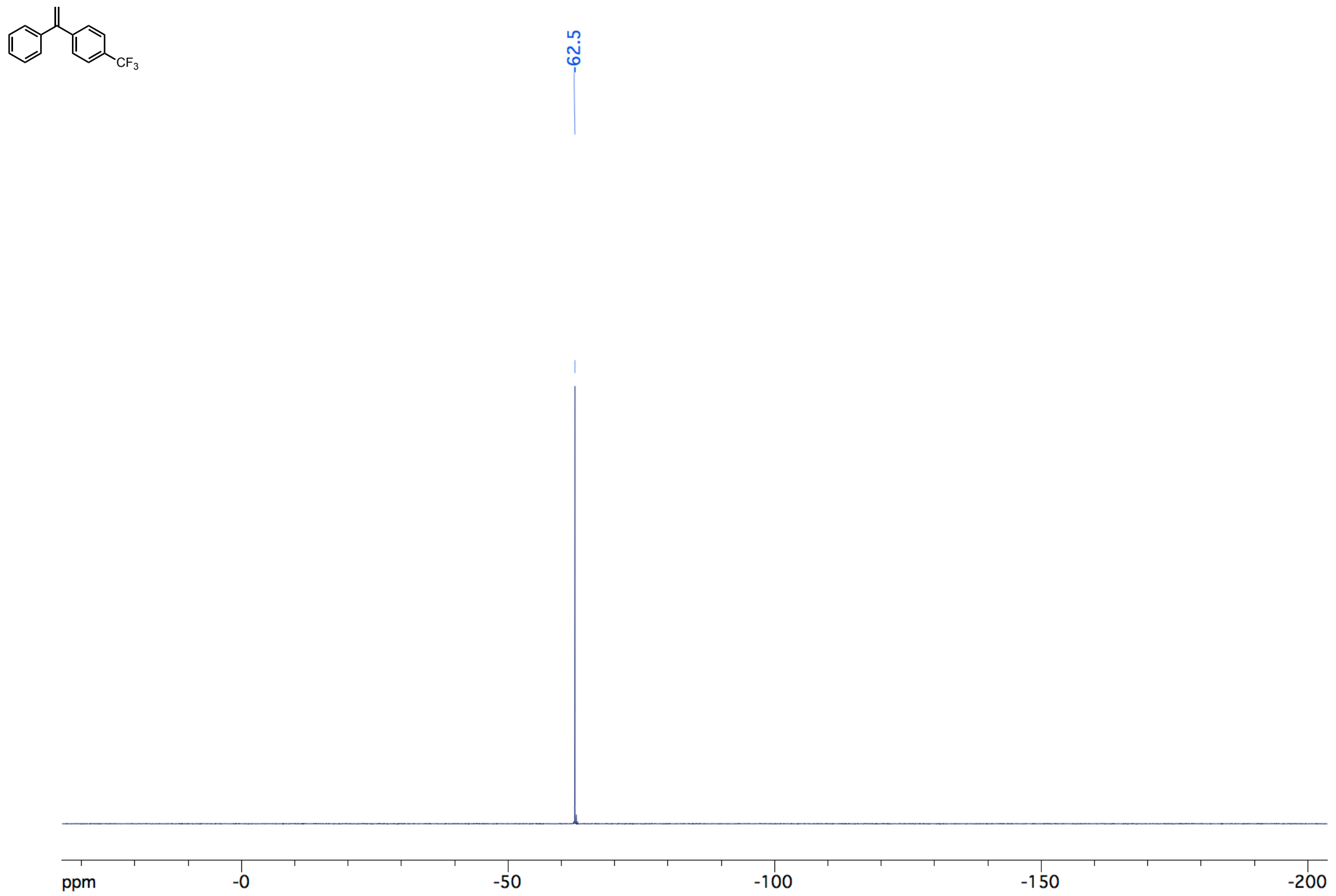
1-Chloro-3-(1-phenylvinyl)benzene (6a) ${ }^{1} \mathrm{H}$ NMR $\left(\mathrm{CDCl}_{3}, 400 \mathrm{MHz}\right)$

otho
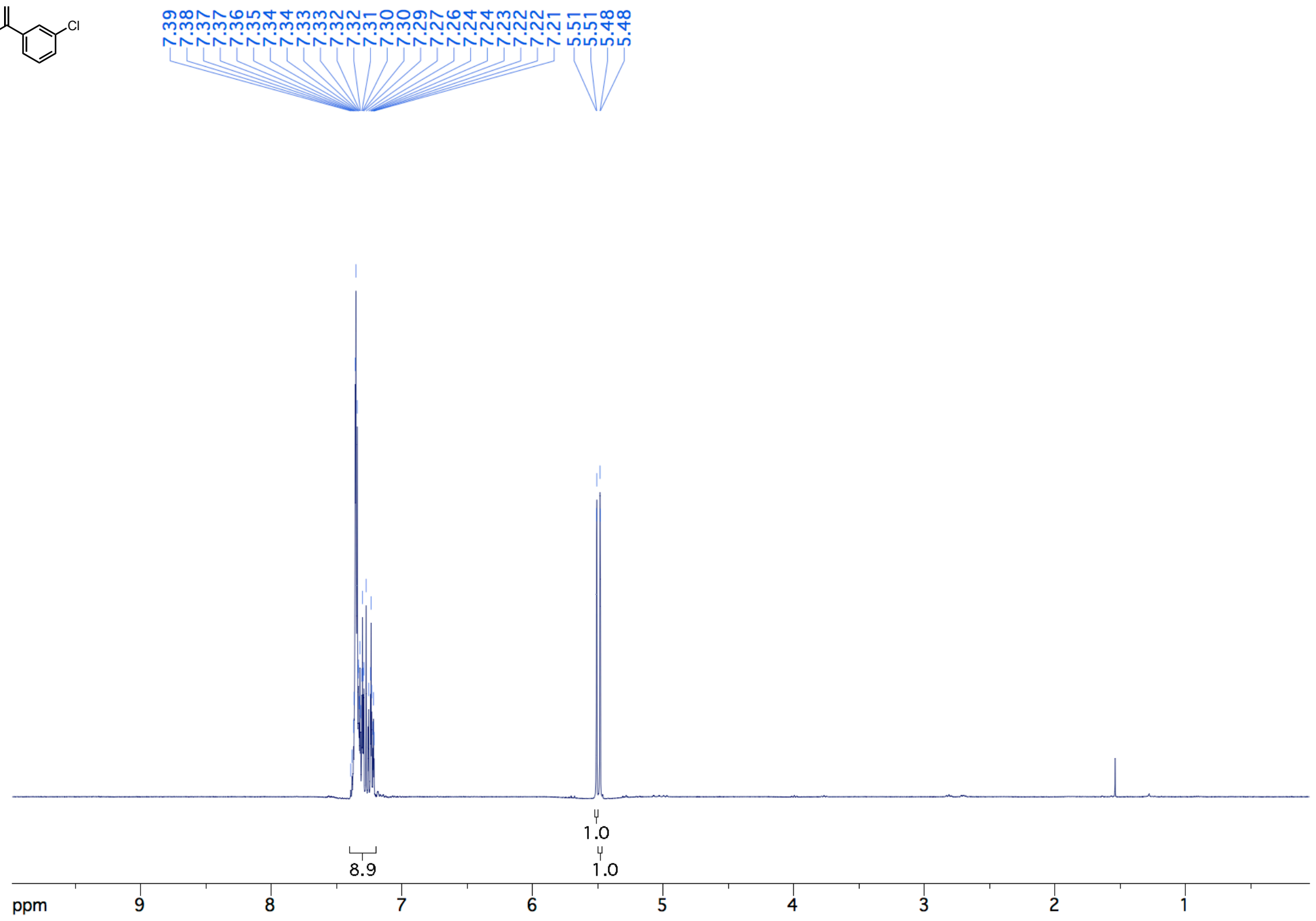

44 
1-Chloro-3-(1-phenylvinyl)benzene (6a) ${ }^{13} \mathrm{C} \mathrm{NMR}\left(\mathrm{CDCl}_{3}, 100 \mathrm{MHz}\right)$

(1)
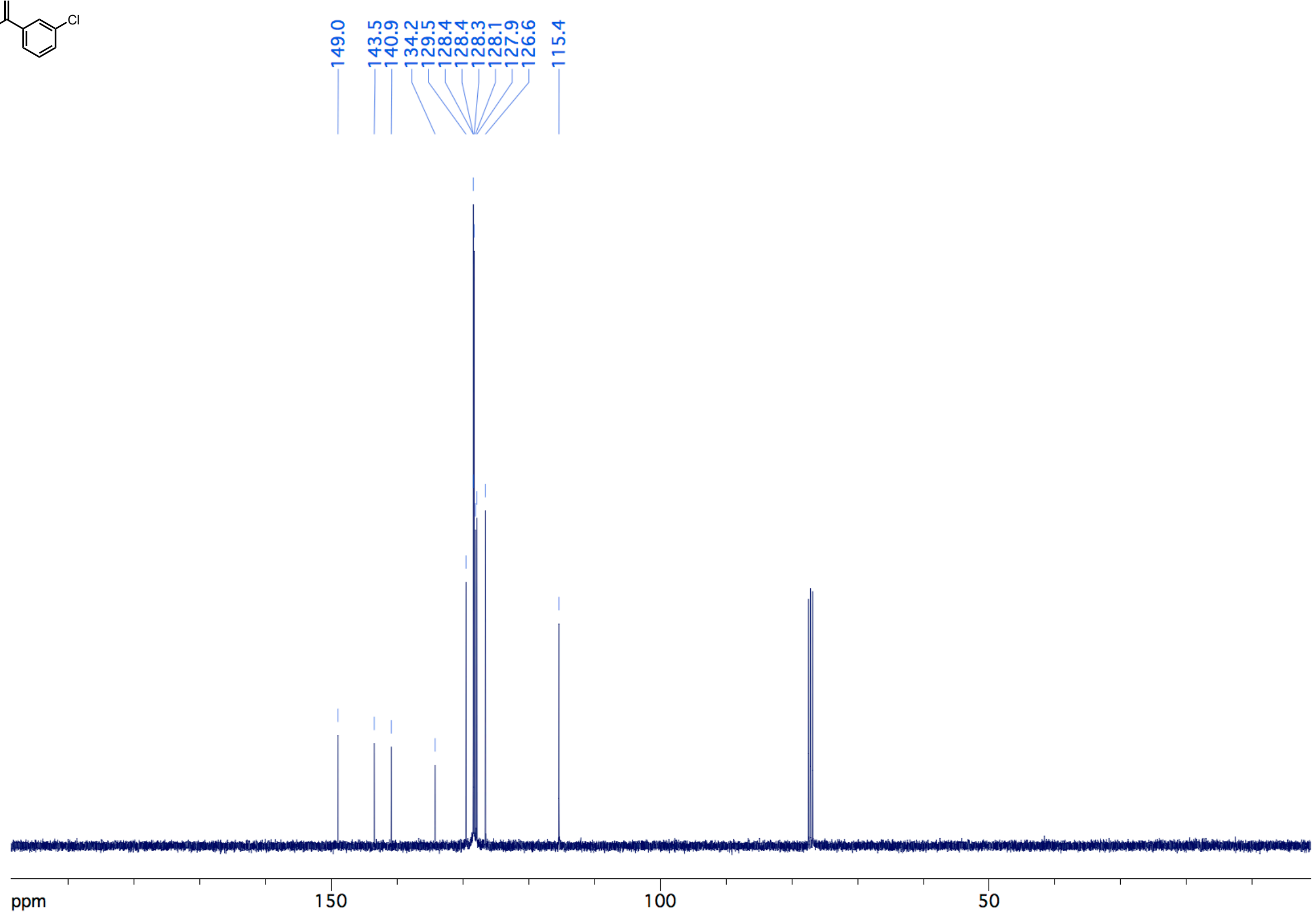

45 

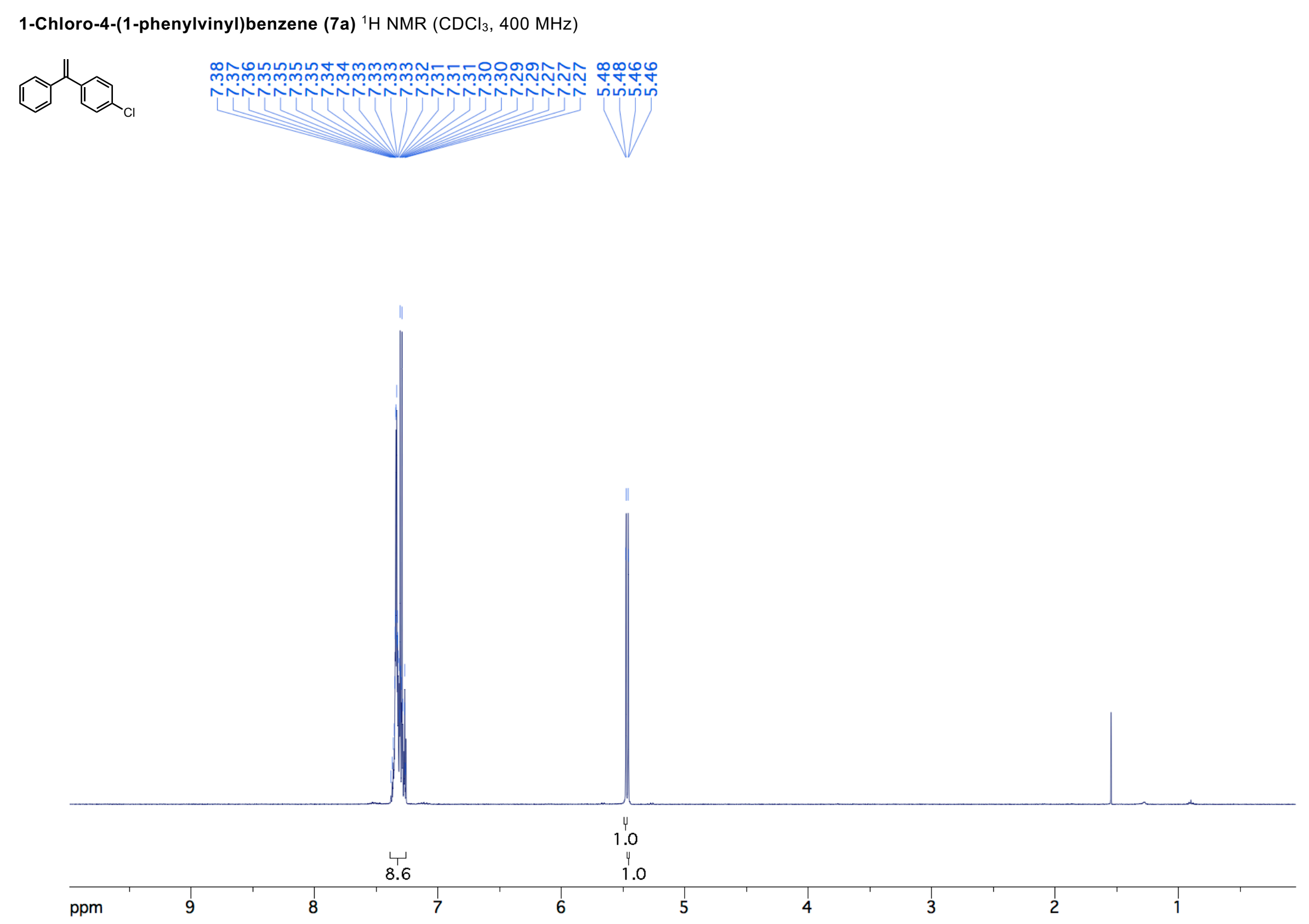
1-Chloro-4-(1-Phenylvinyl)benzene (7a) ${ }^{13} \mathrm{C} \mathrm{NMR}\left(\mathrm{CDCl}_{3}, 100 \mathrm{MHz}\right)$

10
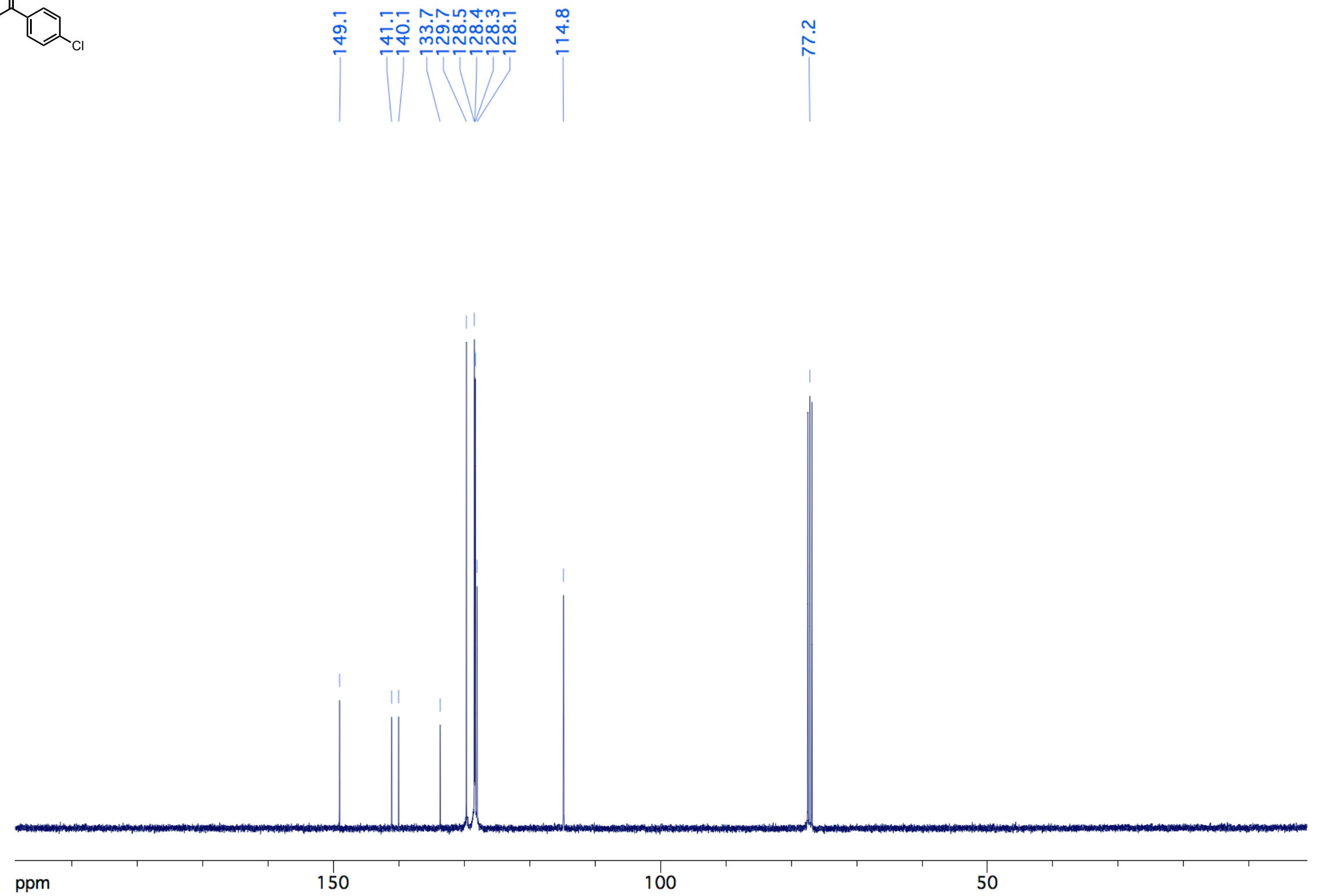


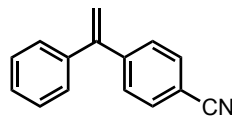

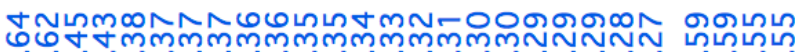

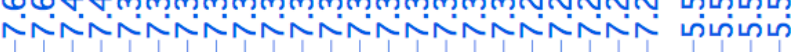

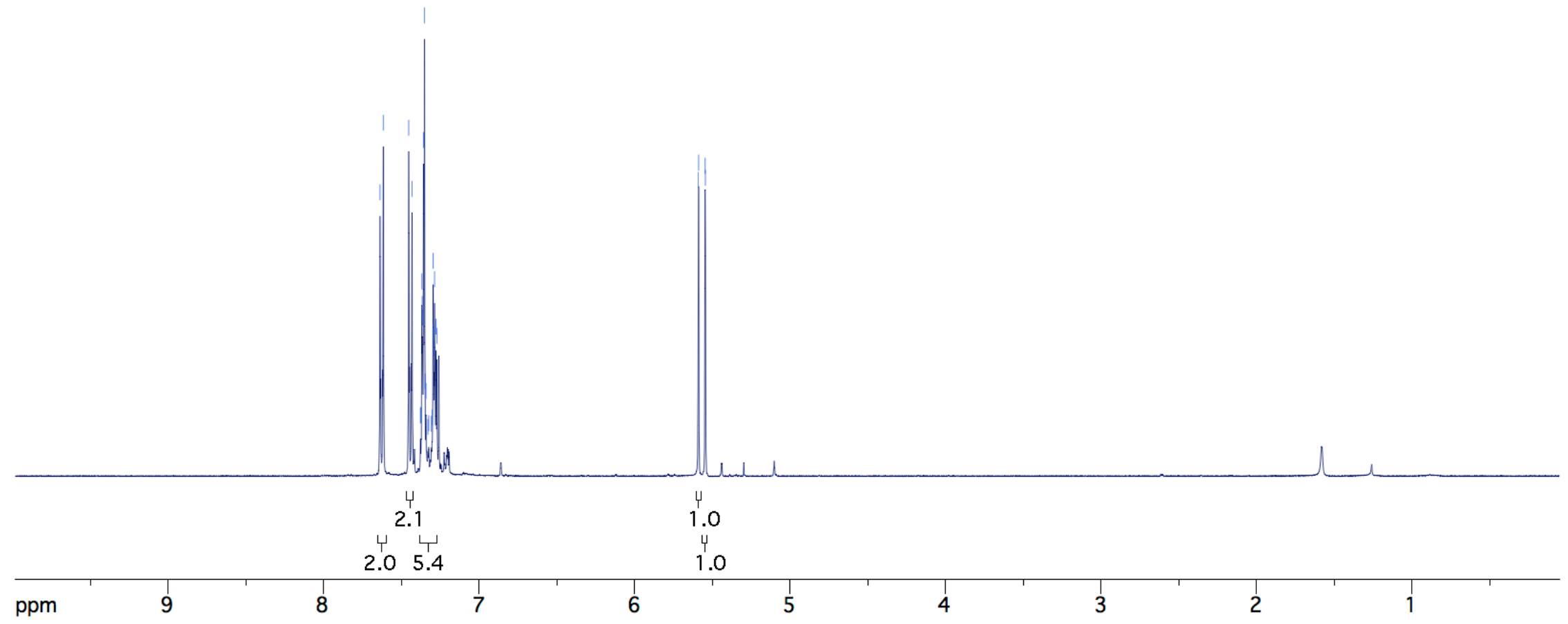



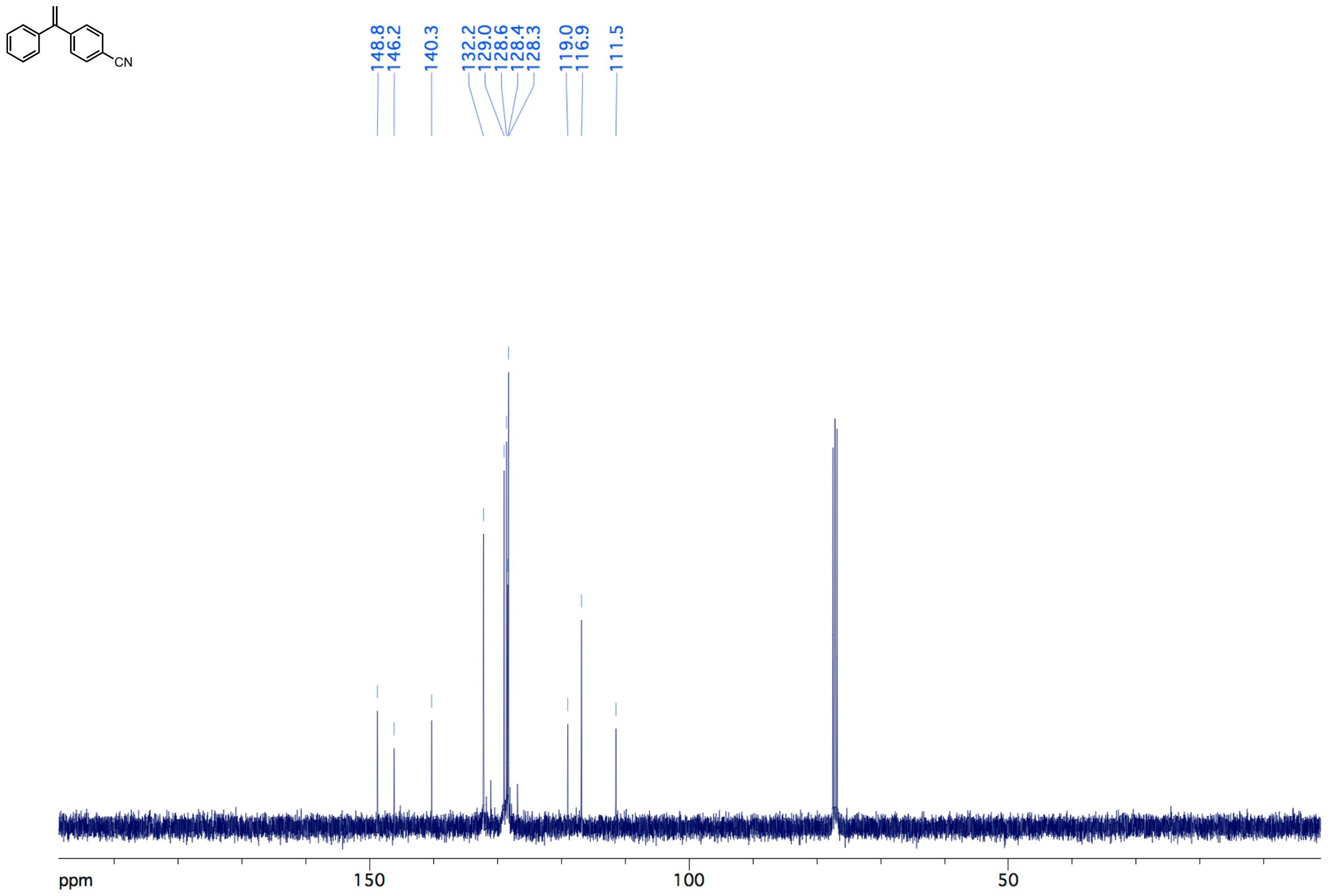

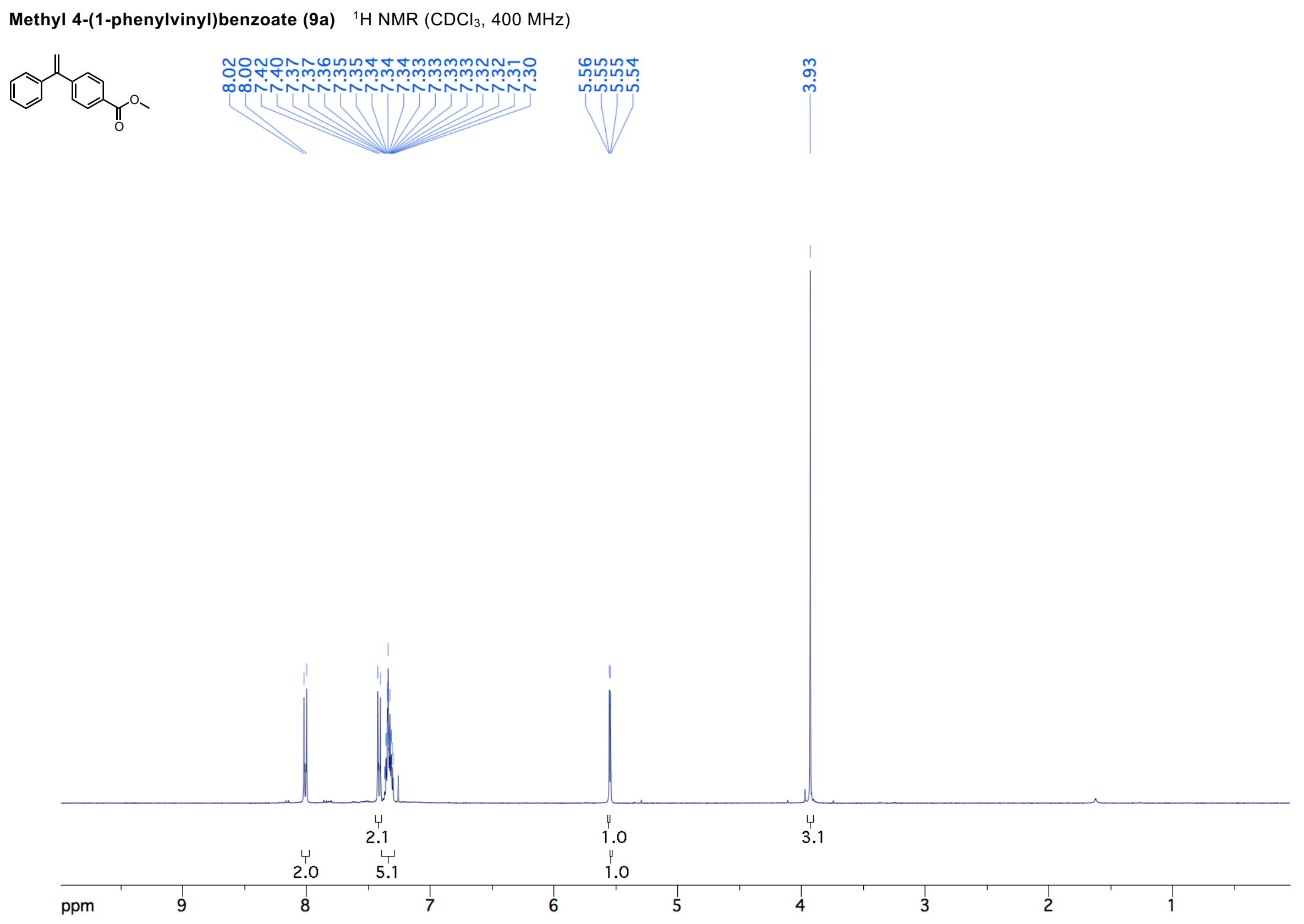

50 
Methyl 4-(1-phenylvinyl)benzoate (9a) ${ }^{13} \mathrm{C} \mathrm{NMR}\left(\mathrm{CDCl}_{3}, 100 \mathrm{MHz}\right)$
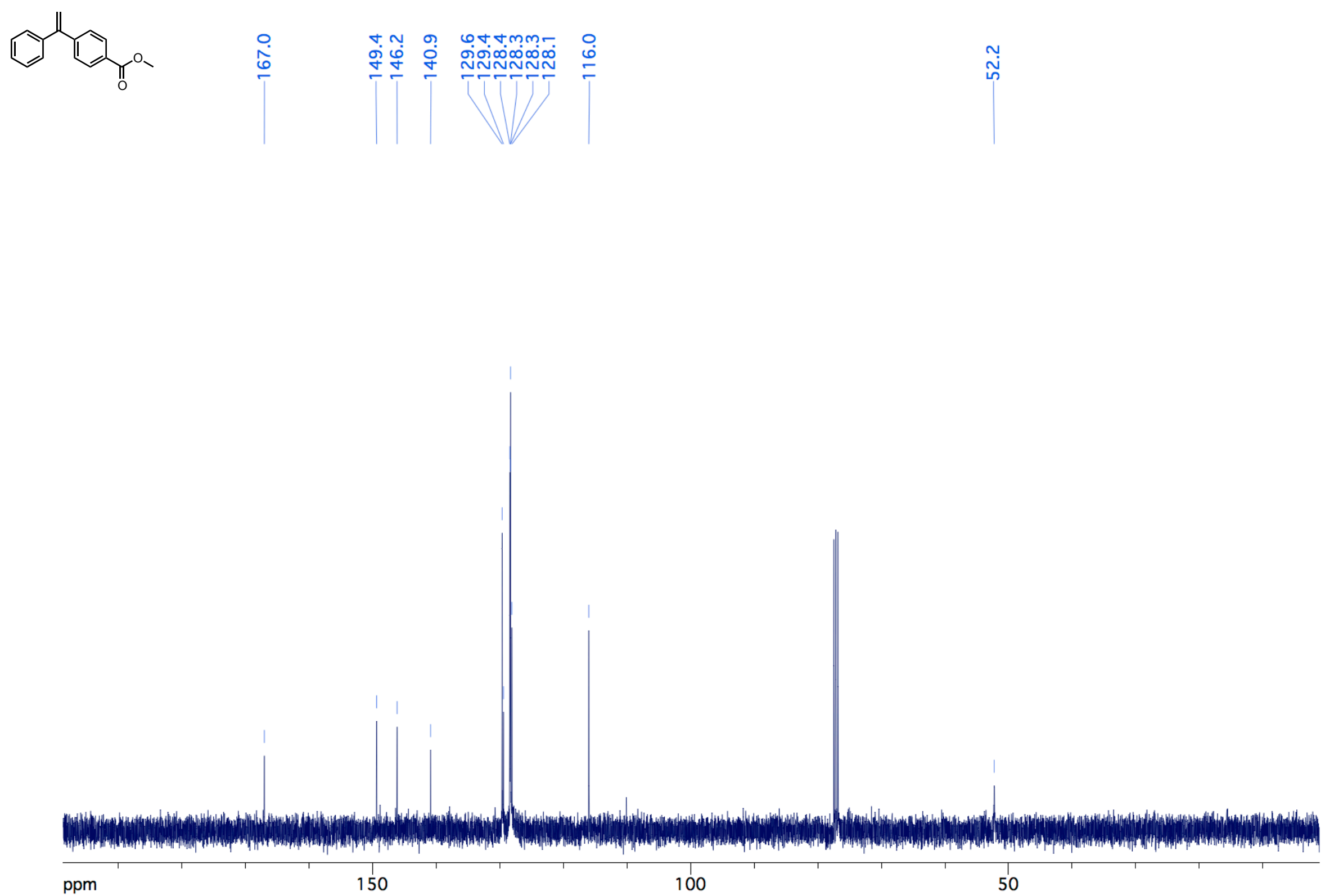


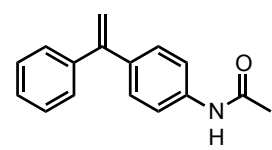

${ }^{1} \mathrm{H} \operatorname{NMR}\left(\mathrm{CDCl}_{3}, 400 \mathrm{MHz}\right)$

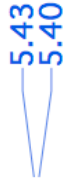

$\stackrel{\infty}{\sim}$

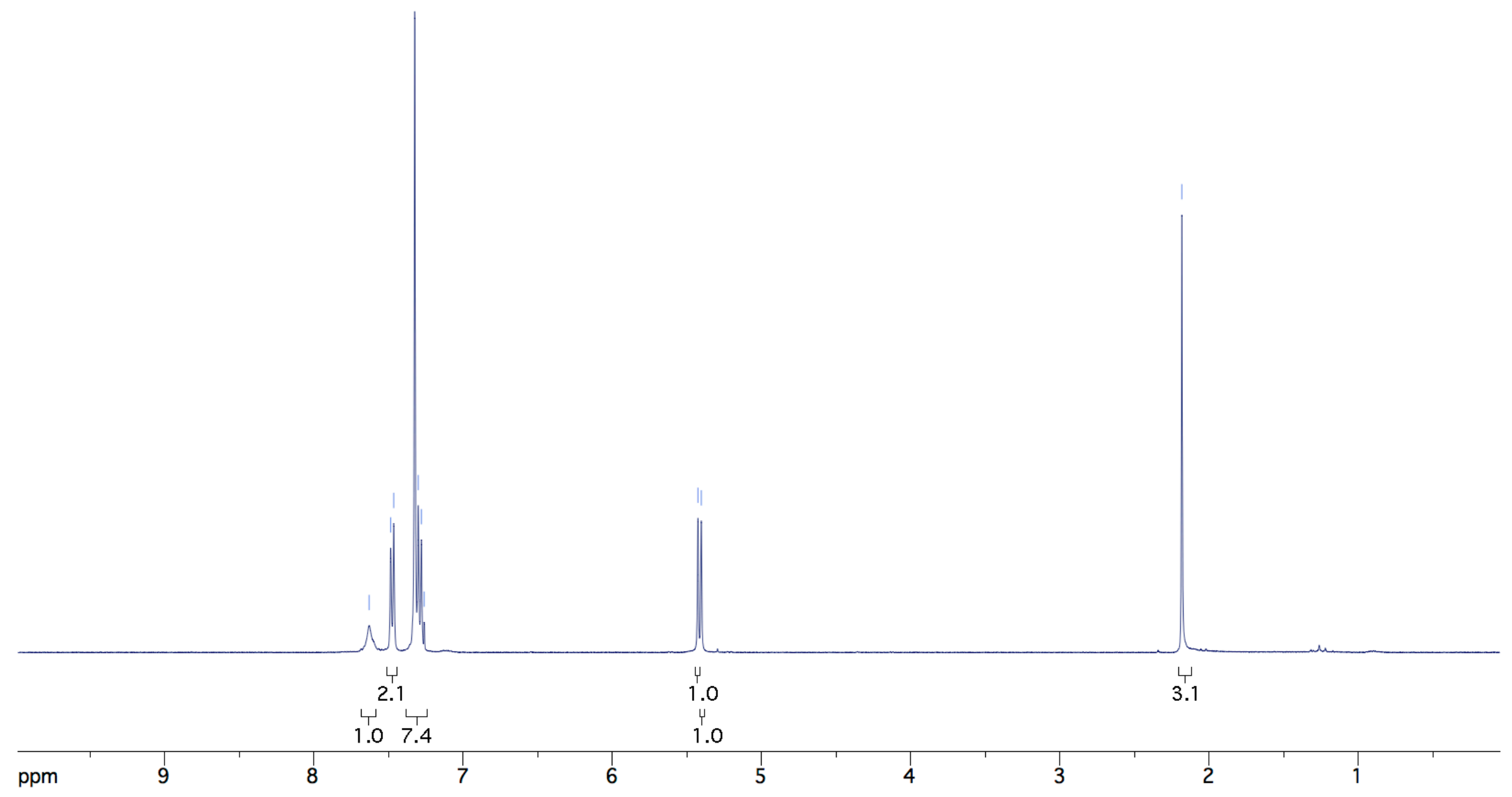



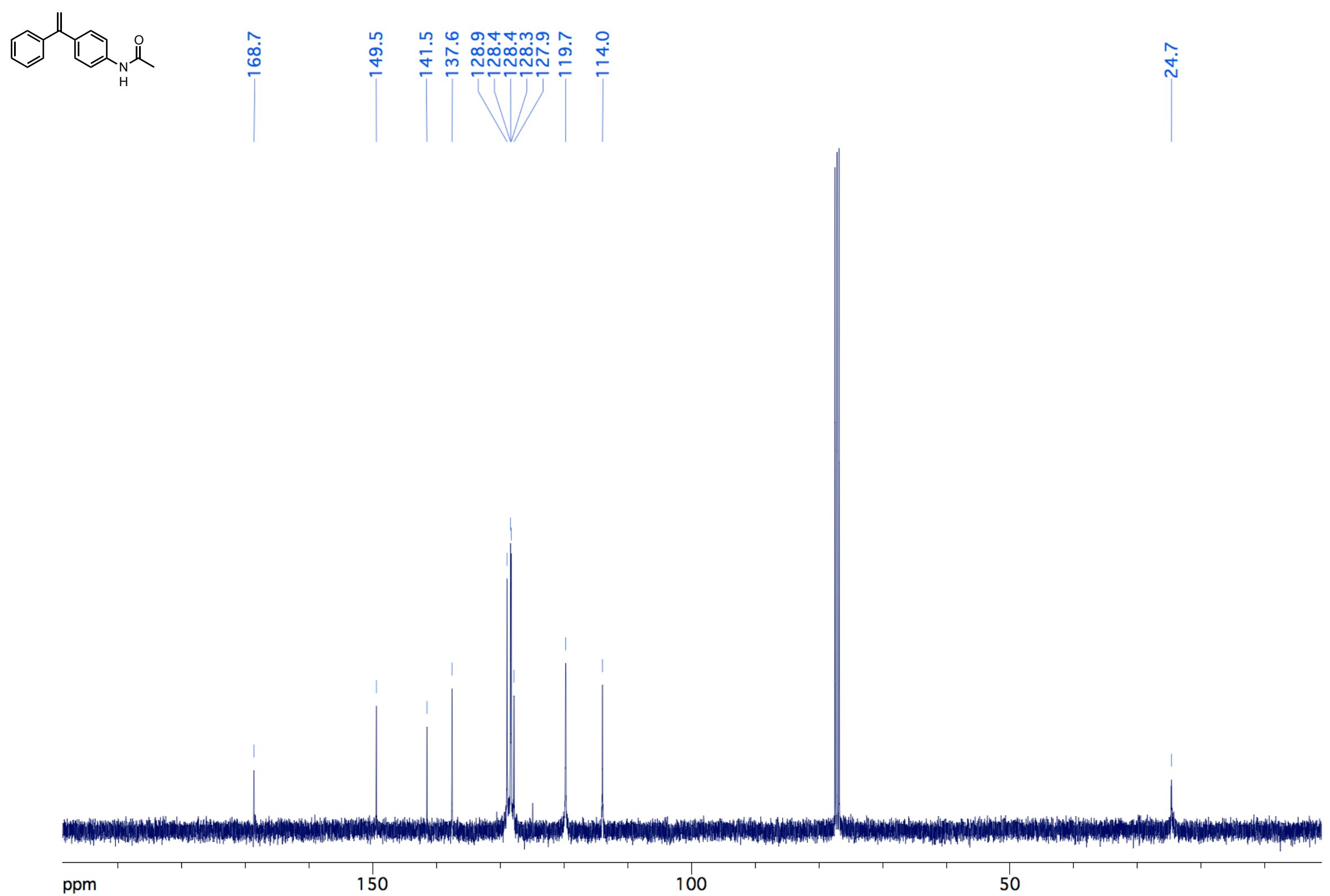
2-(1-Phenylvinyl)pyridine (11a) ${ }^{1} \mathrm{H} \mathrm{NMR}\left(\mathrm{CDCl}_{3}, 400 \mathrm{MHz}\right)$
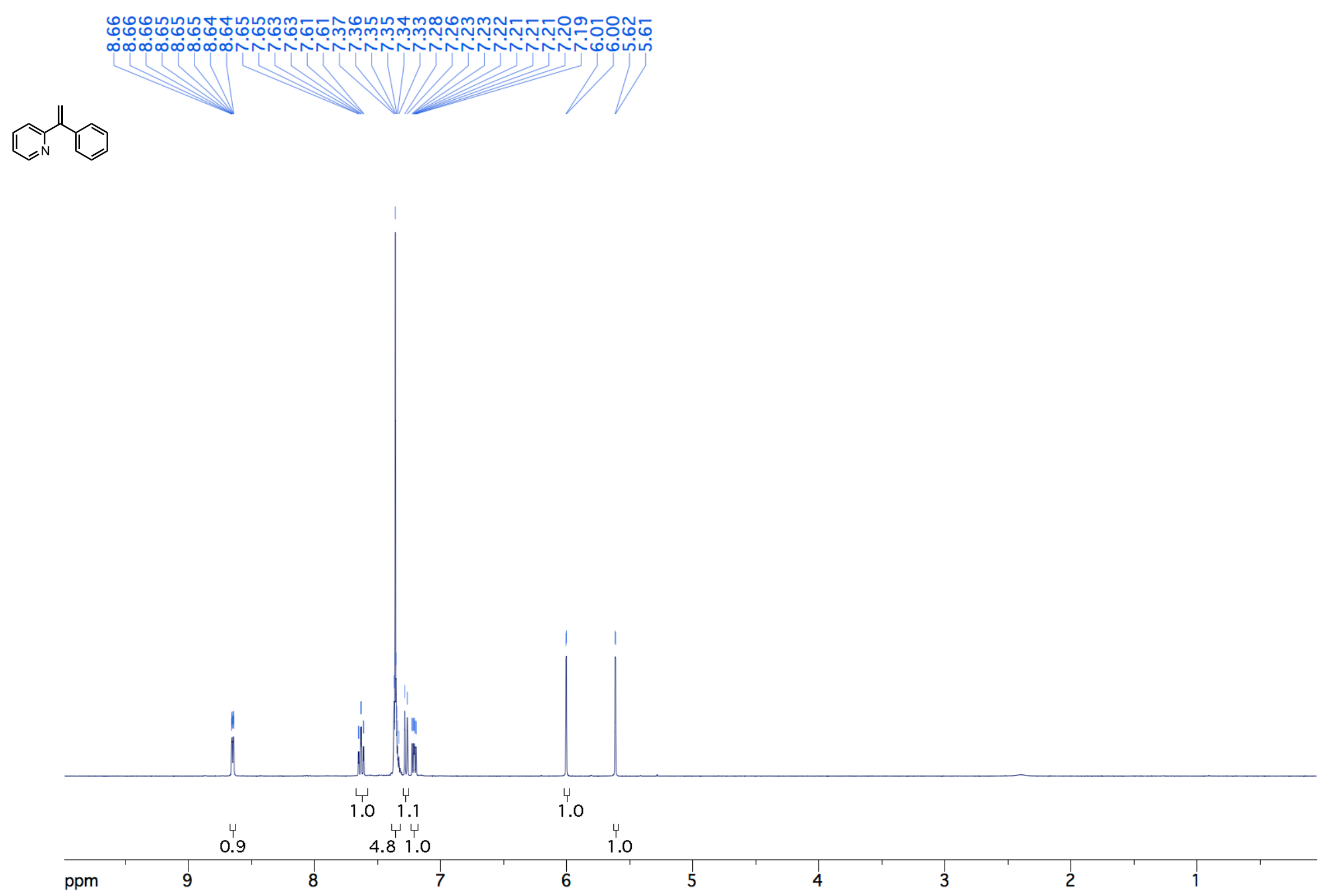

54 
2-(1-Phenylvinyl)pyridine (11a) ${ }^{13} \mathrm{C} \mathrm{NMR}\left(\mathrm{CDCl}_{3}, 100 \mathrm{MHz}\right)$

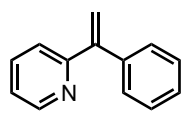

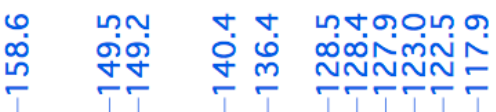

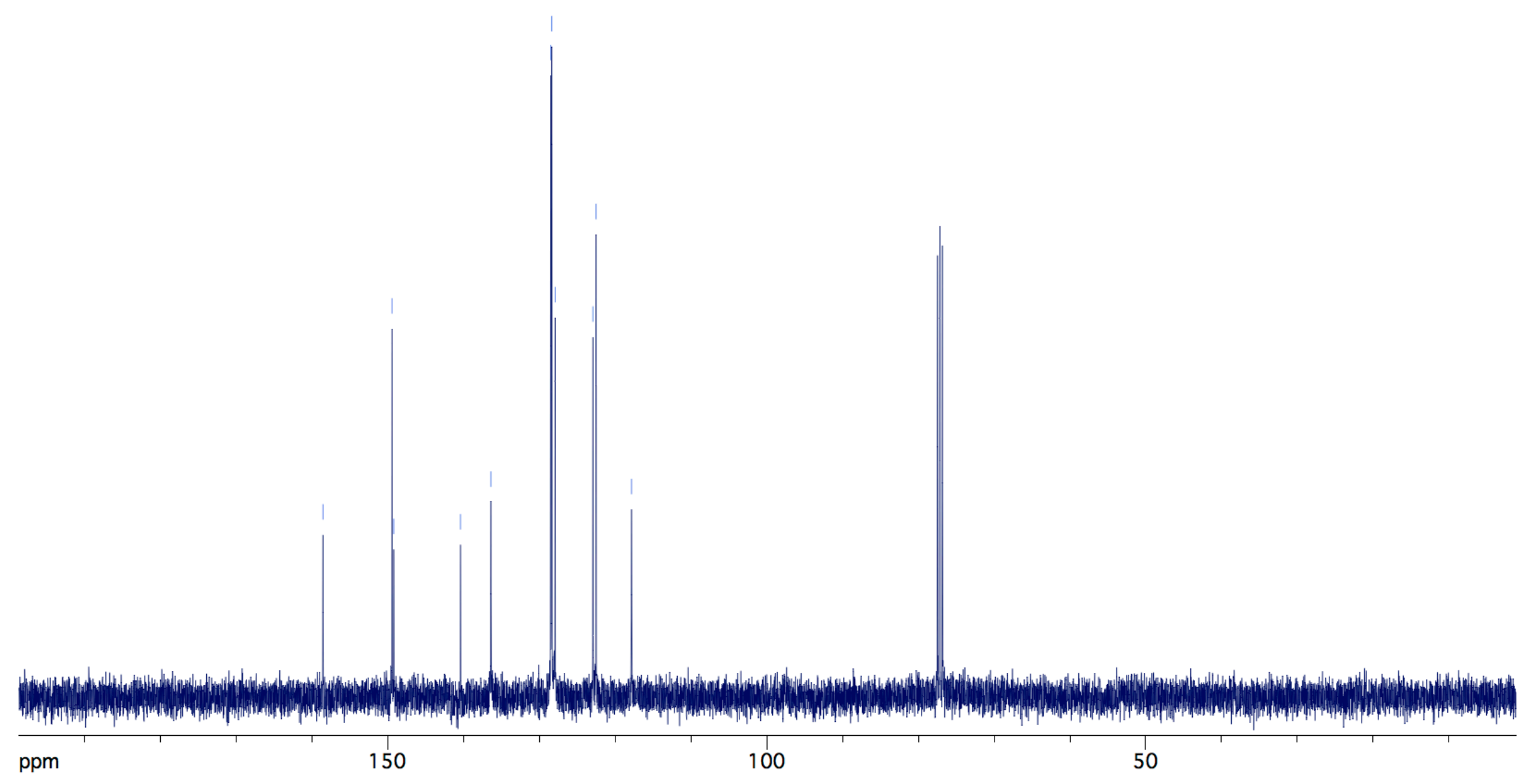


1-Methyl-2-(1-phenylvinyl)benzene (12a)

${ }^{1} \mathrm{H} \mathrm{NMR}\left(\mathrm{CDCl}_{3}, 400 \mathrm{MHz}\right)$

oth
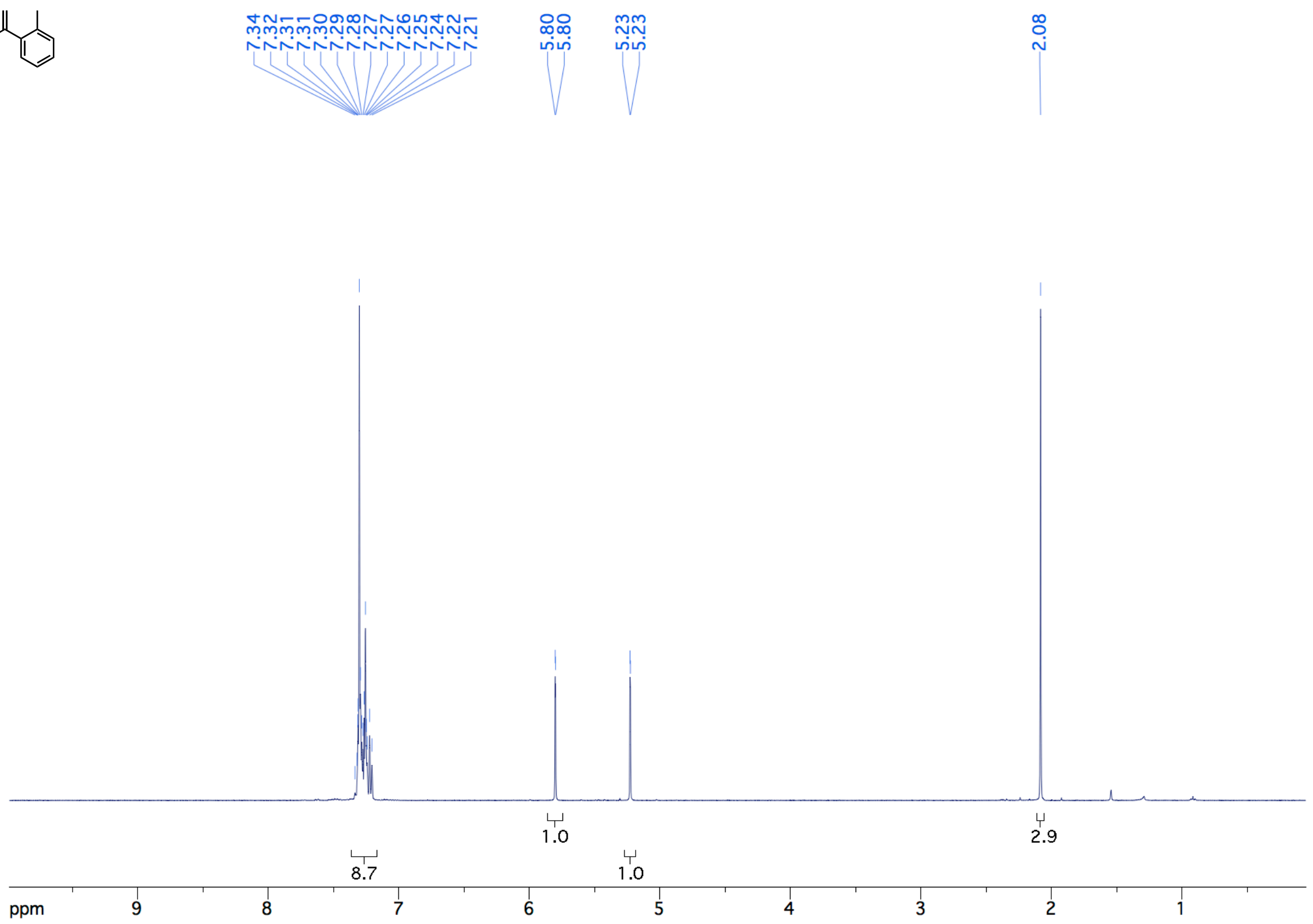

56 
1-Methyl-2-(1-phenylvinyl)benzene (12a)

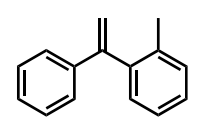

${ }^{13} \mathrm{C}$ NMR $\left(\mathrm{CDCl}_{3}, 100 \mathrm{MHz}\right)$

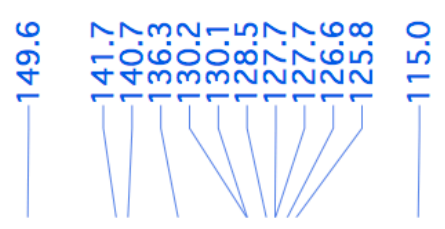

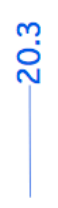

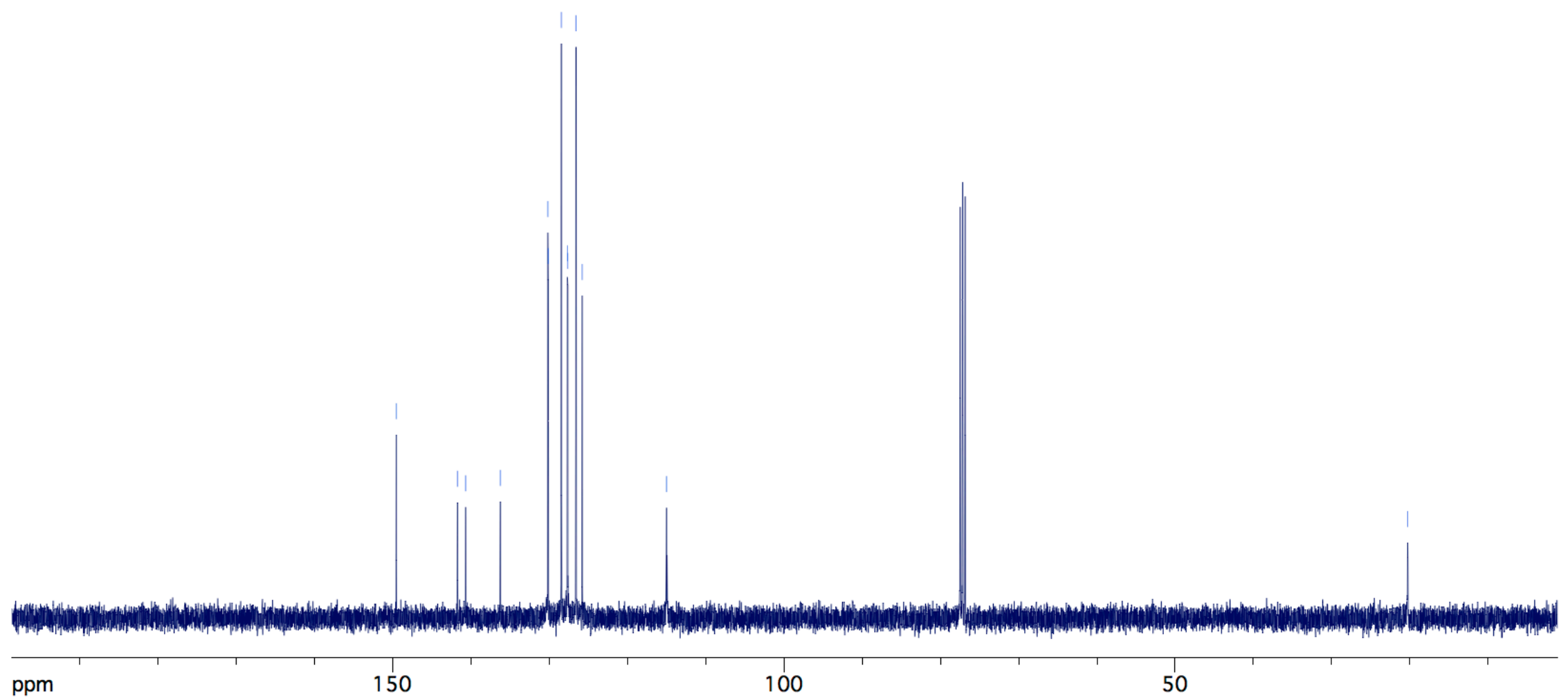

57 
1-Methyl-3-(1-phenylvinyl)benzene (13a)

${ }^{1} \mathrm{H} \mathrm{NMR}\left(\mathrm{CDCl}_{3}, 400 \mathrm{MHz}\right)$

otey
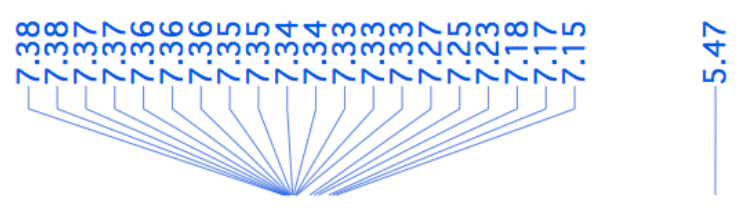

$\stackrel{n}{n}$

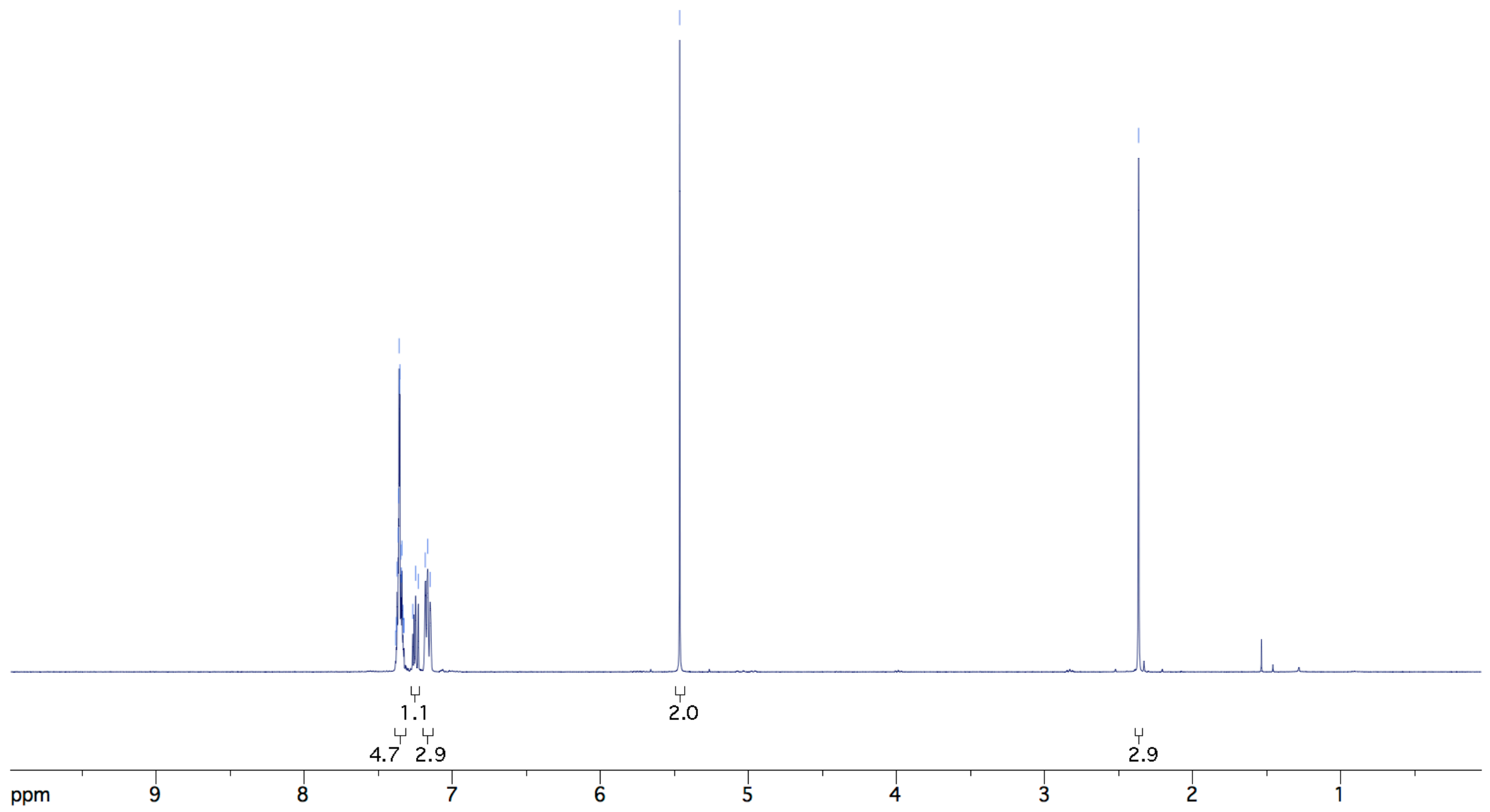

58 


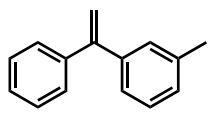

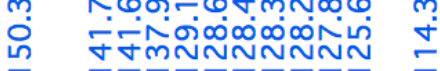

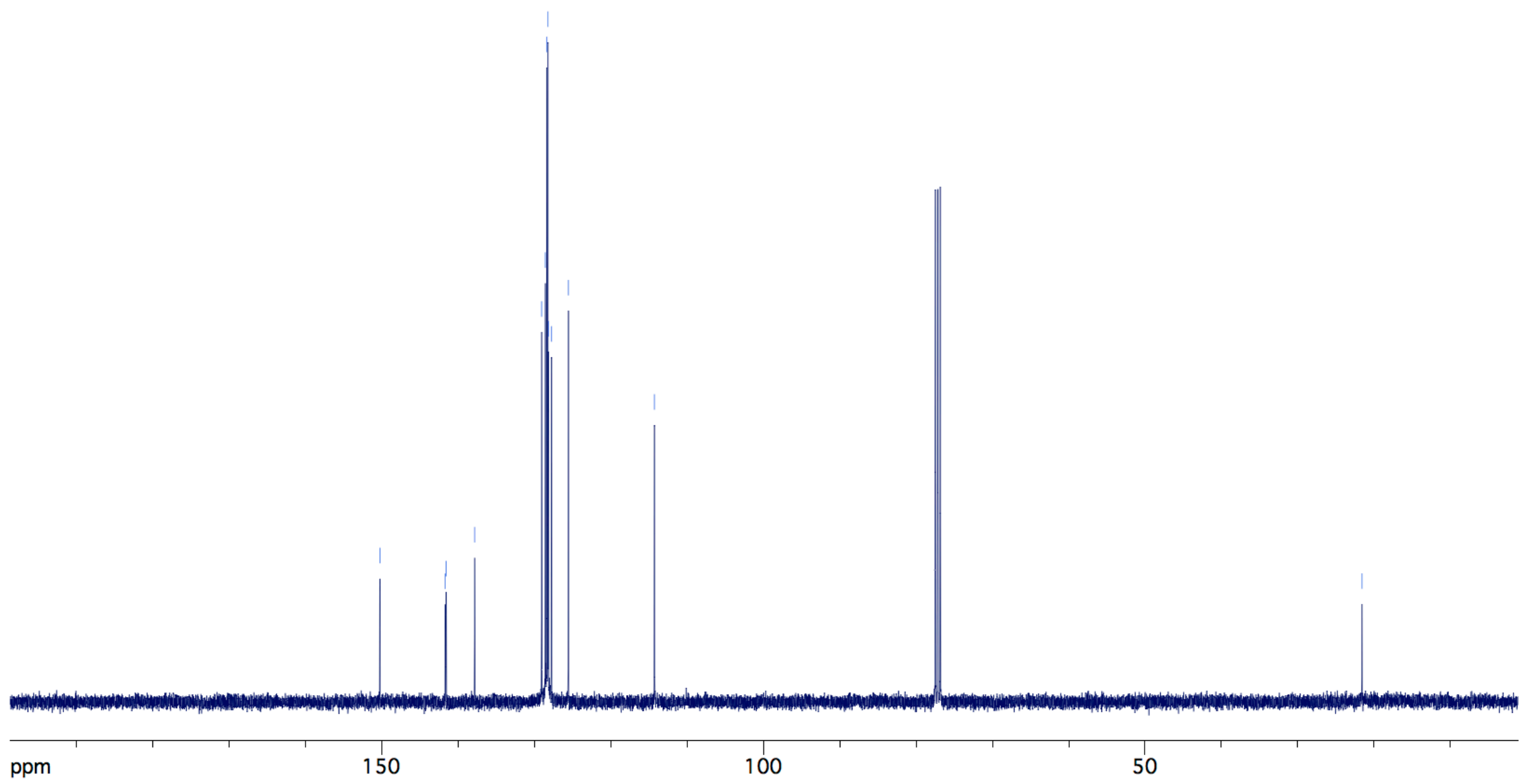


1-Methyl-4-(1-phenylvinyl)benzene (14a) $\quad{ }^{1} \mathrm{H} \mathrm{NMR}\left(\mathrm{CDCl}_{3}, 400 \mathrm{MHz}\right)$
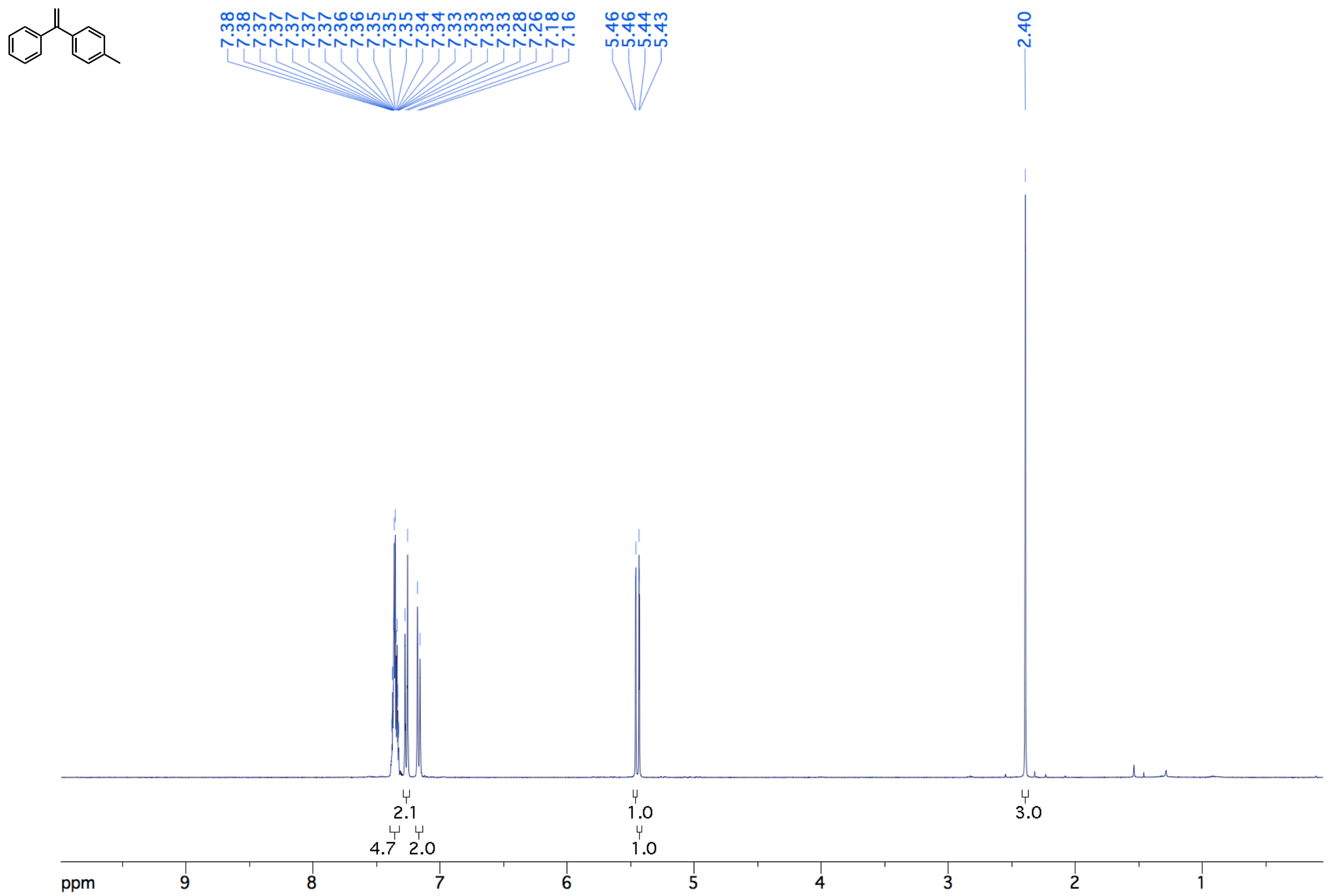

60 

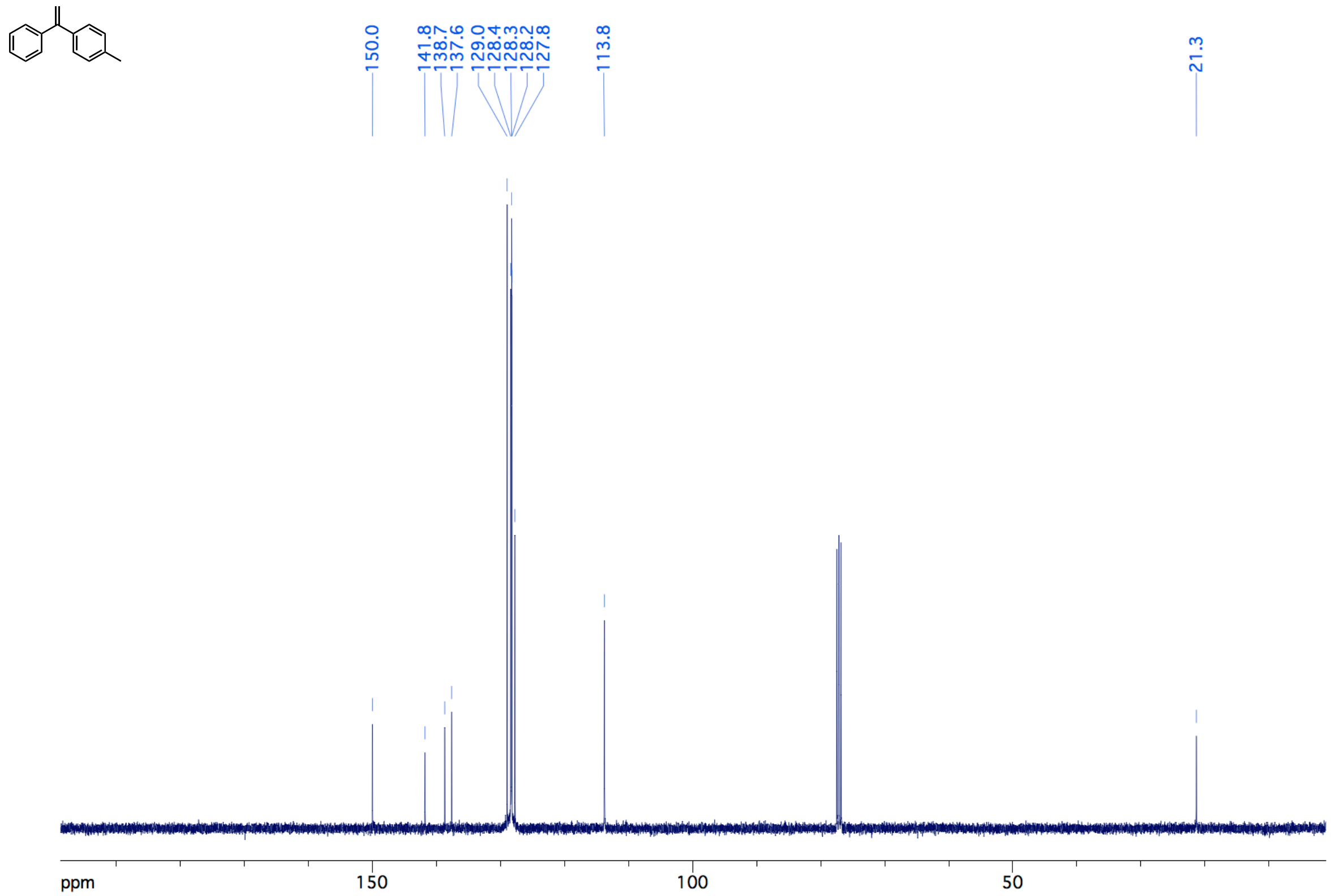
${ }^{1} \mathrm{H} \mathrm{NMR}\left(\mathrm{CDCl}_{3}, 400 \mathrm{MHz}\right)$

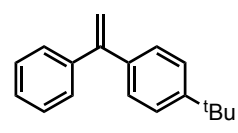

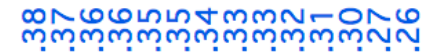

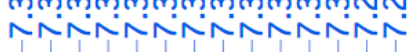

\&.d

เก็

${ }^{\mathrm{B} U}$

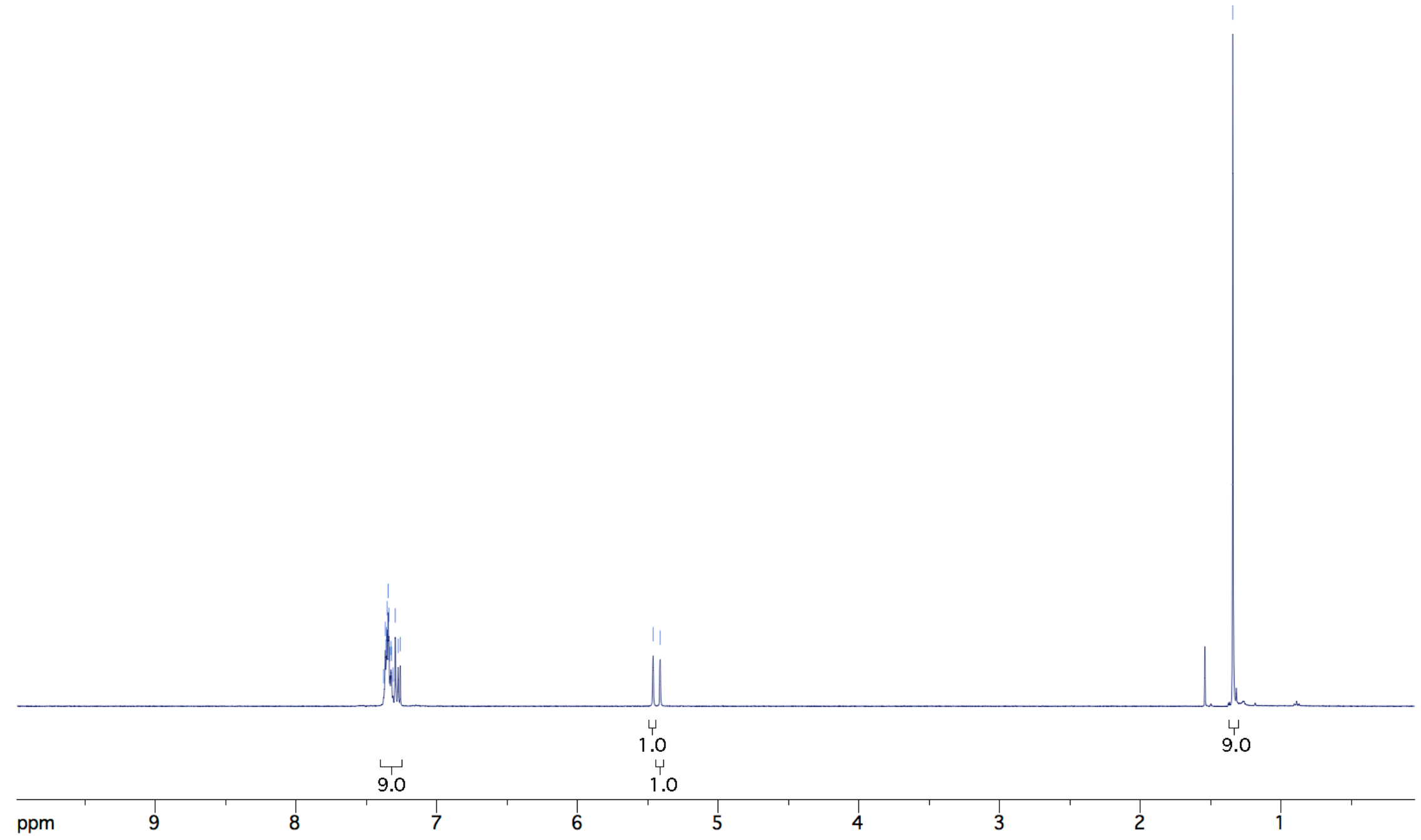



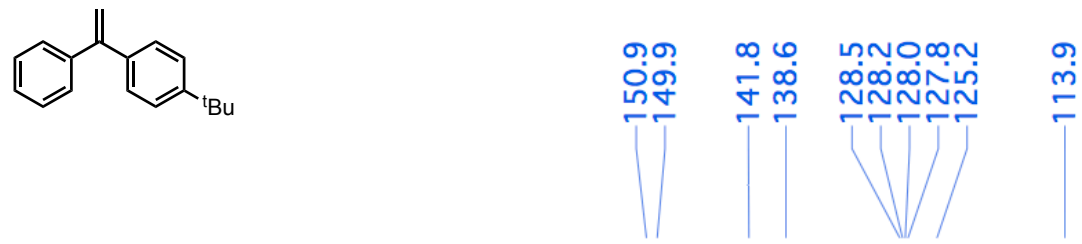

$$
\text { กั่ }
$$

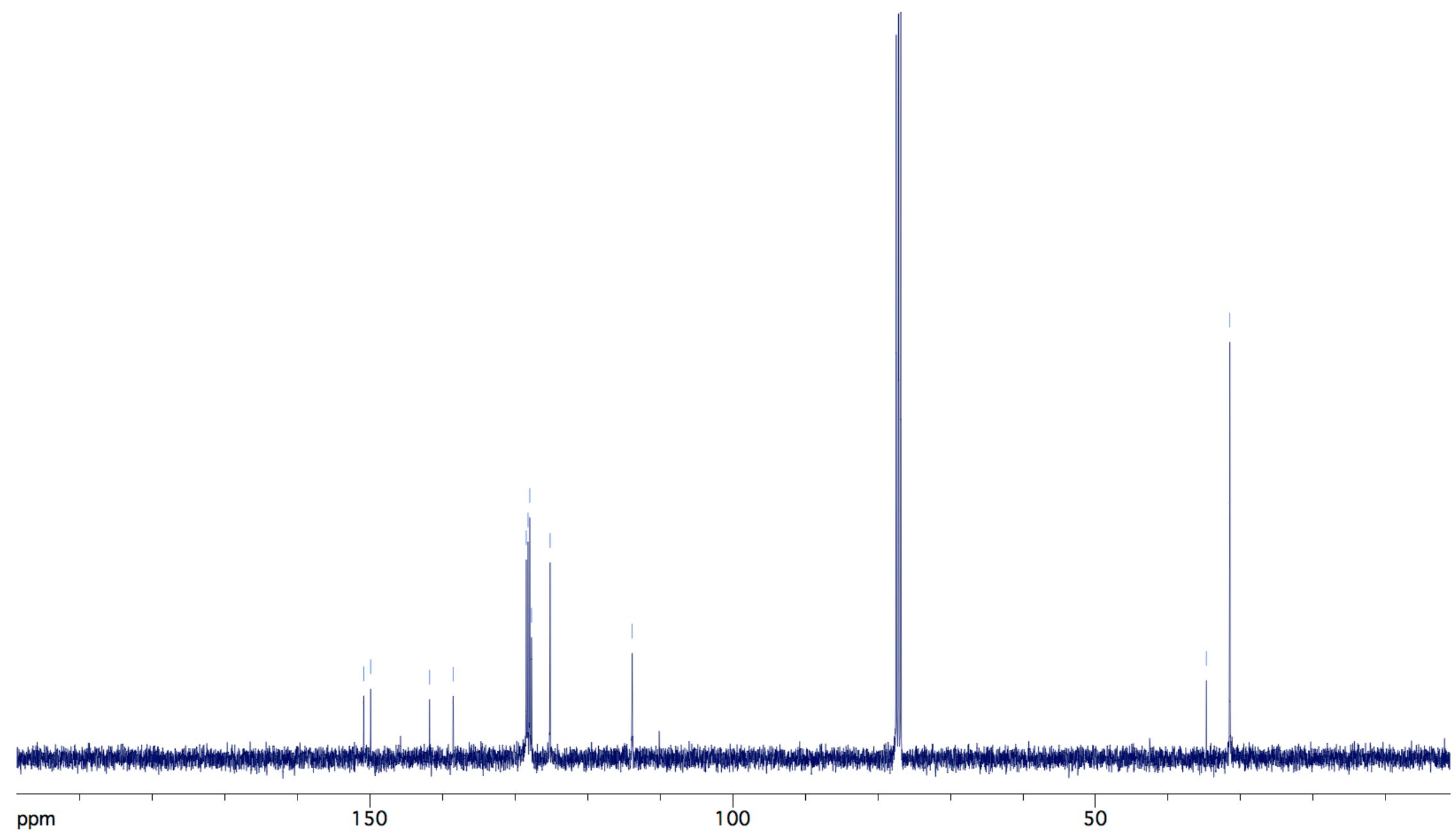


1-Methoxy-4-(1-phenylvinyl)benzene (16a)

${ }^{1} \mathrm{H} \mathrm{NMR}\left(\mathrm{CDCl}_{3}, 400 \mathrm{MHz}\right)$

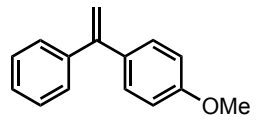

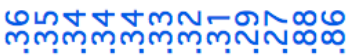

아ำ
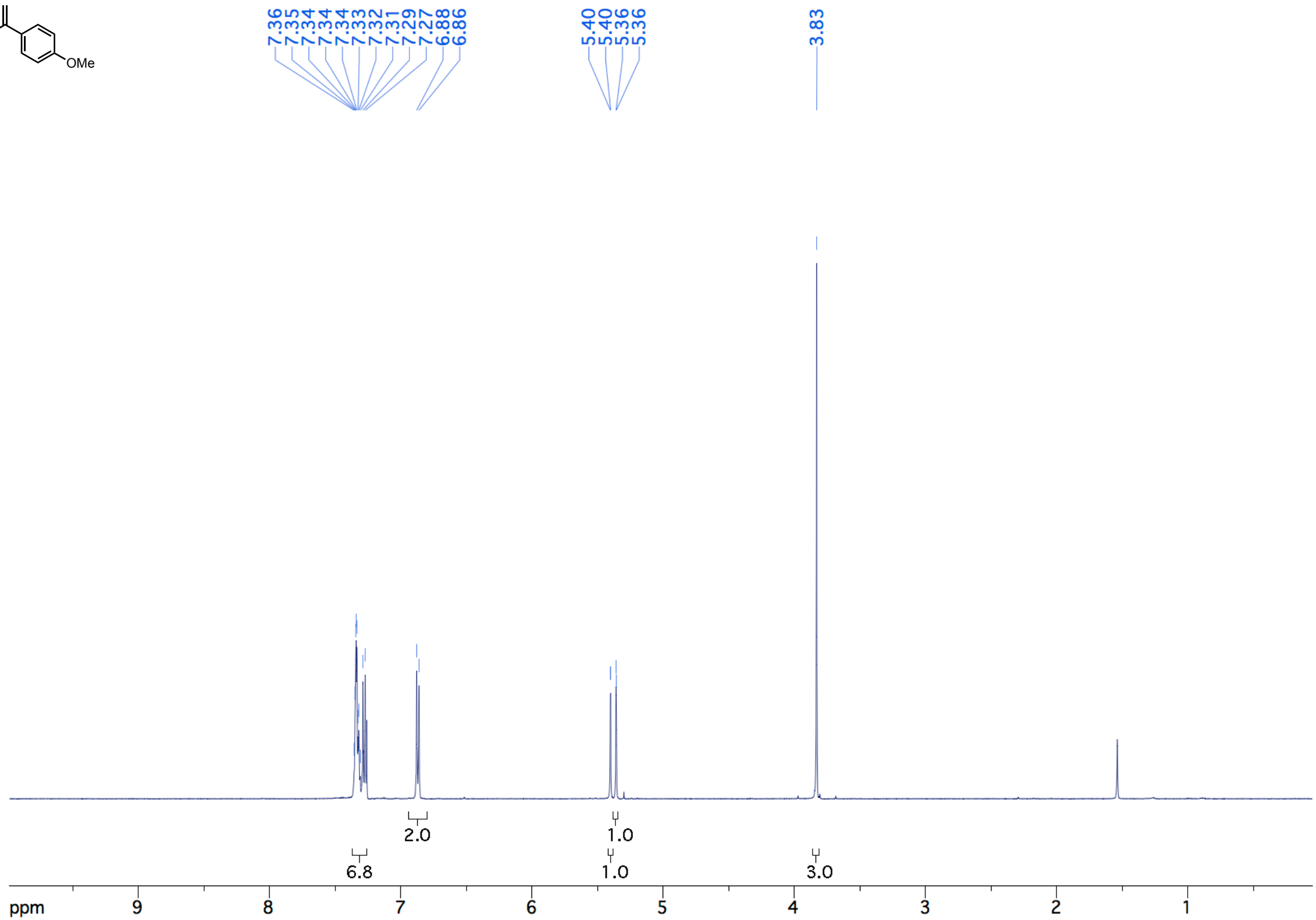

64 

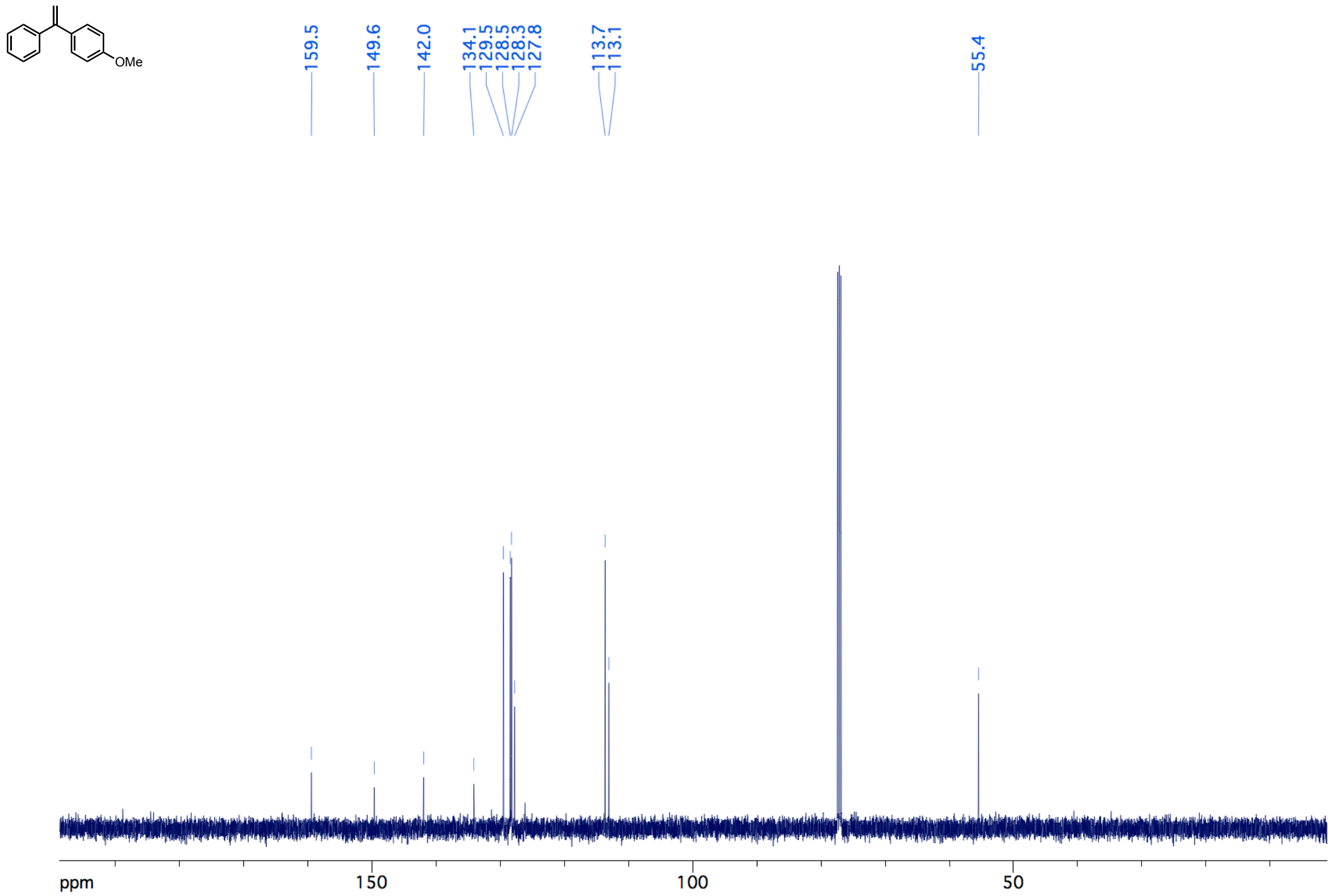
${ }^{1} \mathrm{H} \mathrm{NMR}\left(\mathrm{CDCl}_{3}, 400 \mathrm{MHz}\right)$

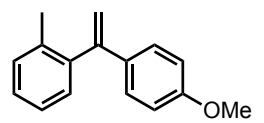

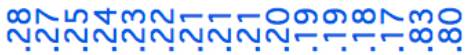

:

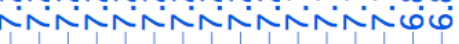

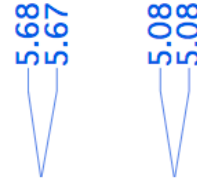

$\stackrel{\infty}{\infty}$

$\stackrel{\circ}{\sim}$

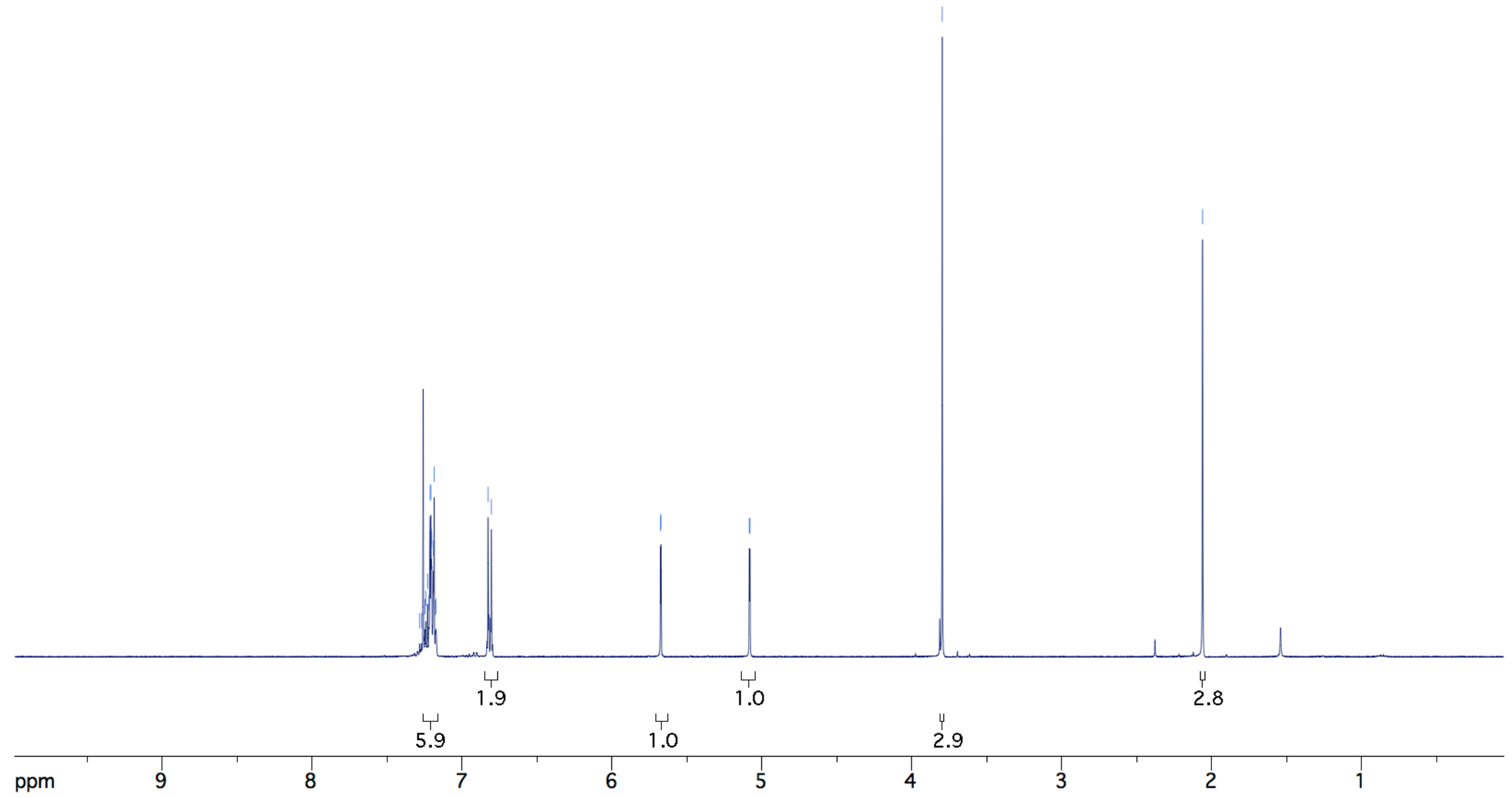



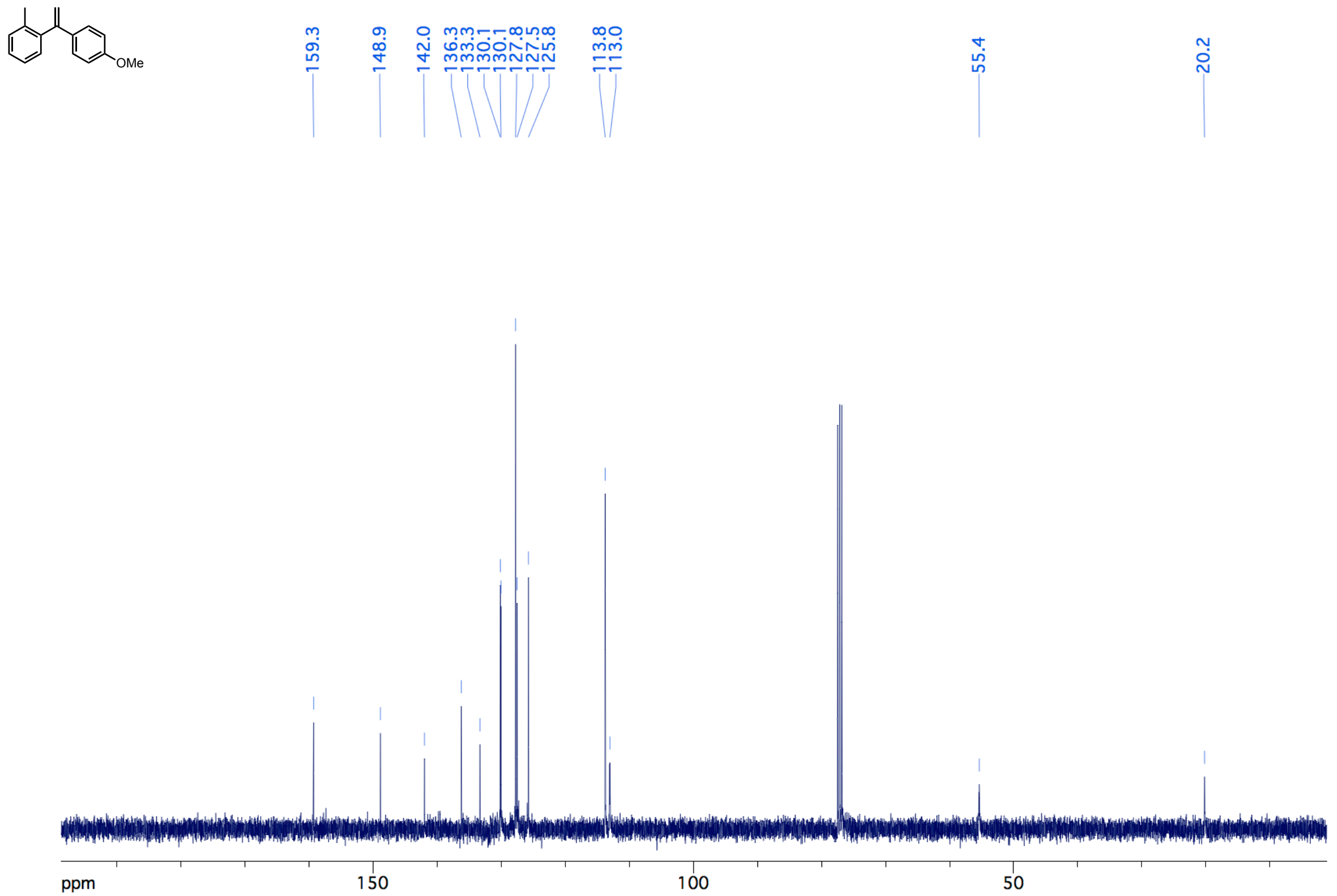

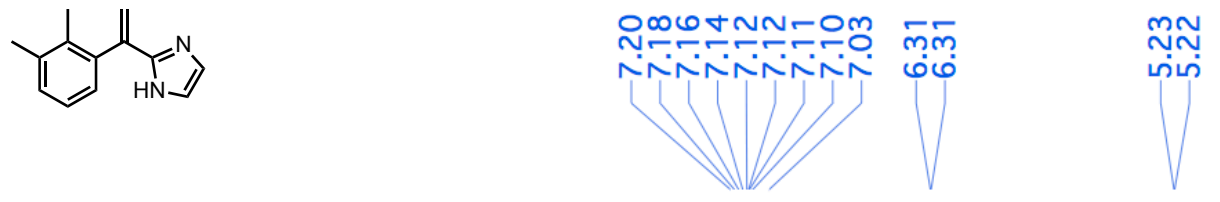

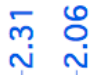

กุบ

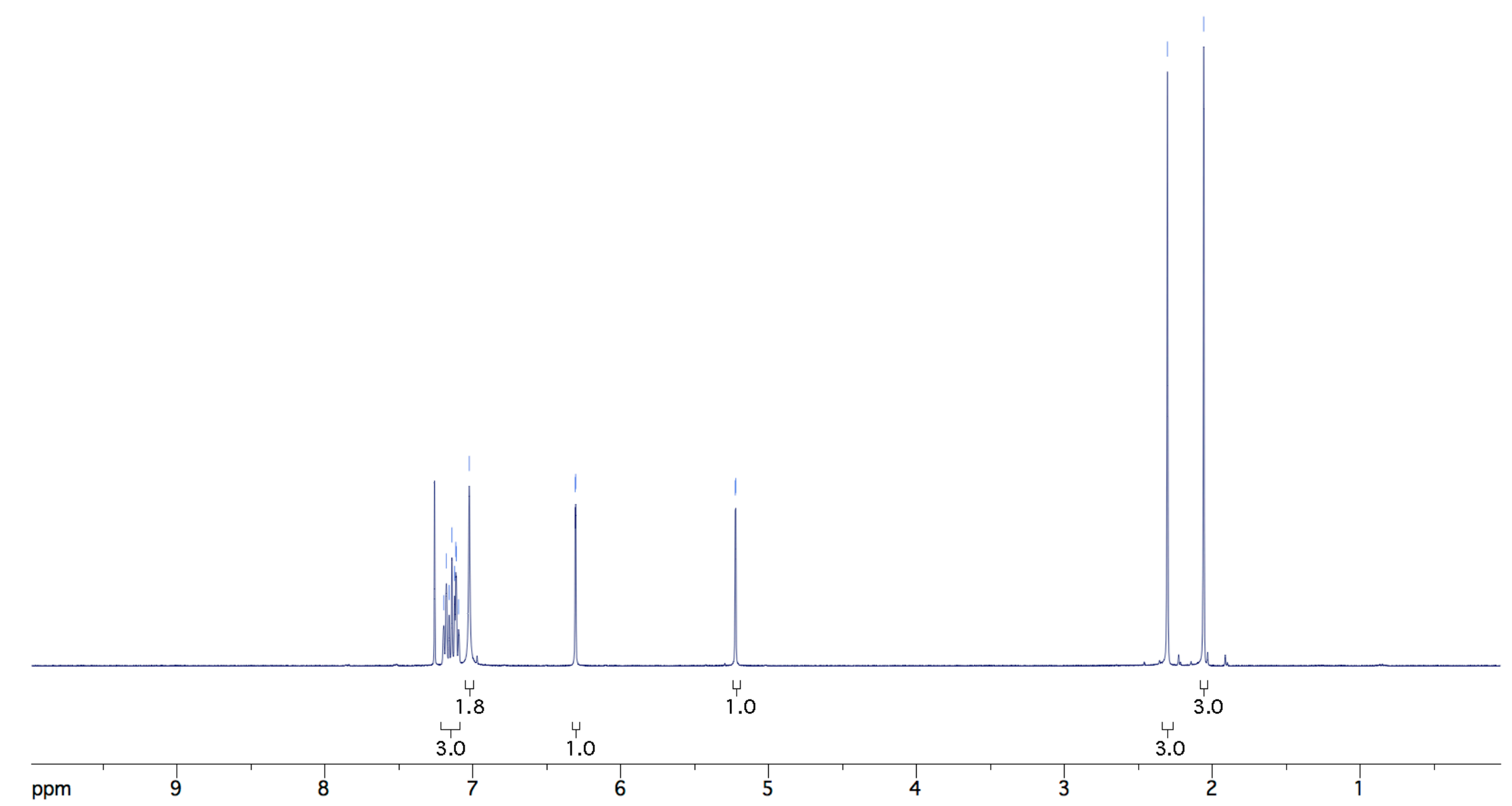



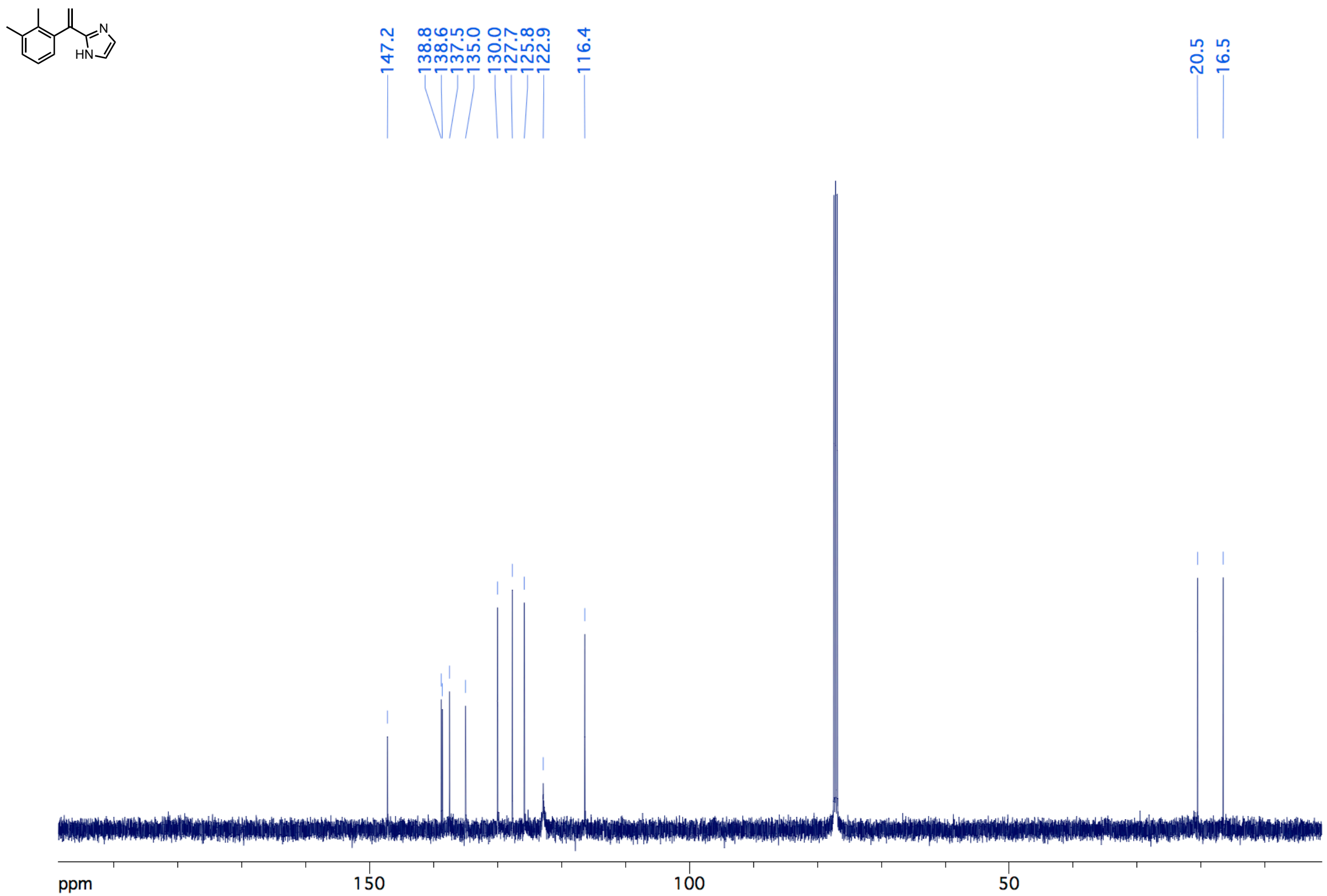
1,2,3-Trimethoxy-5-(1-(4-methoxyphenyl)vinyl)benzene (19a) ${ }^{1} \mathrm{H} \mathrm{NMR}\left(\mathrm{CDCl}_{3}, 400 \mathrm{MHz}\right)$
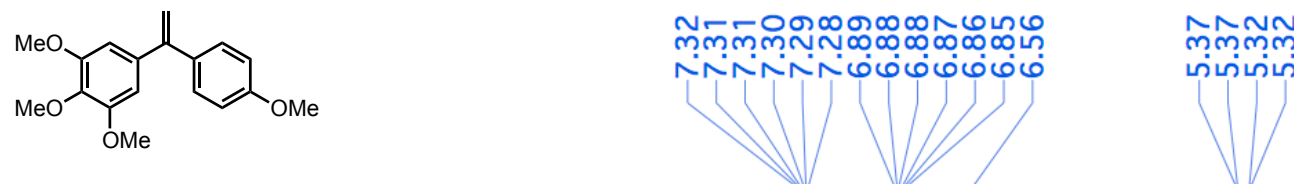

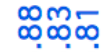

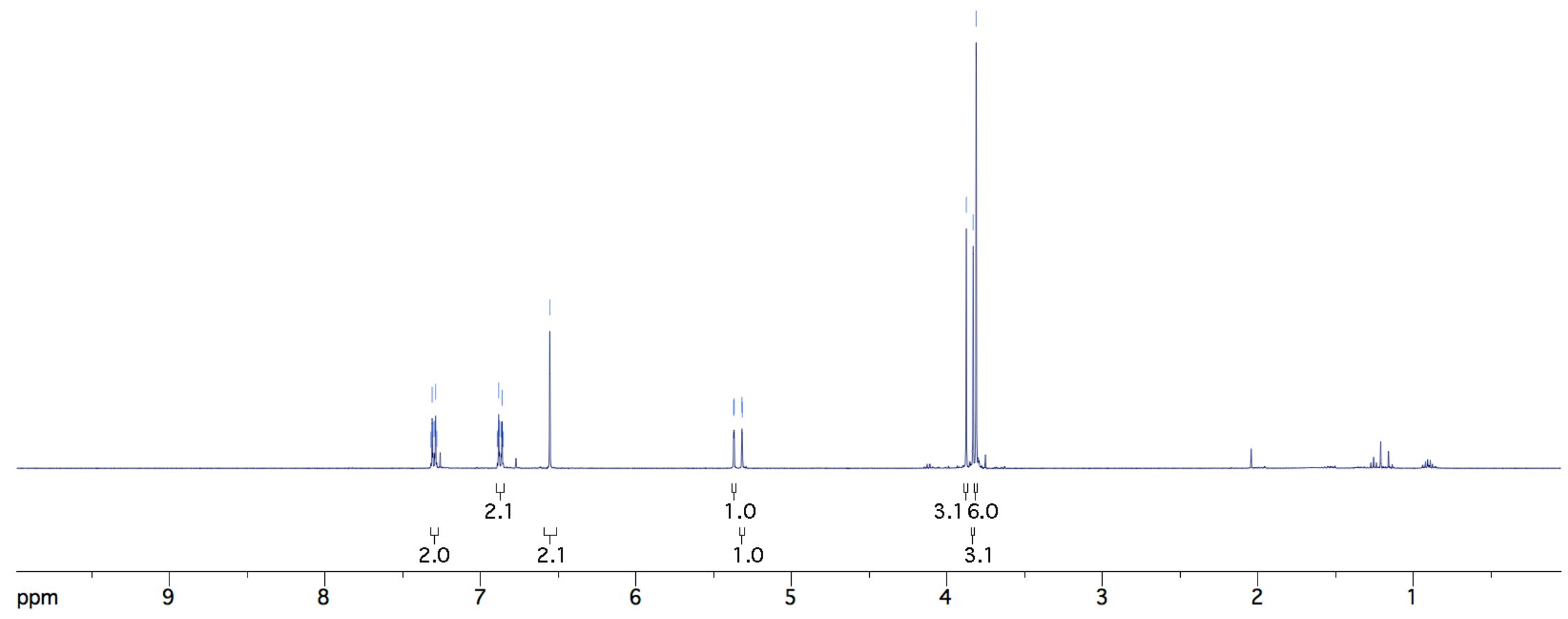


1,2,3-Trimethoxy-5-(1-(4-methoxyphenyl)vinyl)benzene (19a) ${ }^{13} \mathrm{C} \mathrm{NMR}\left(\mathrm{CDCl}_{3}, 100 \mathrm{MHz}\right)$
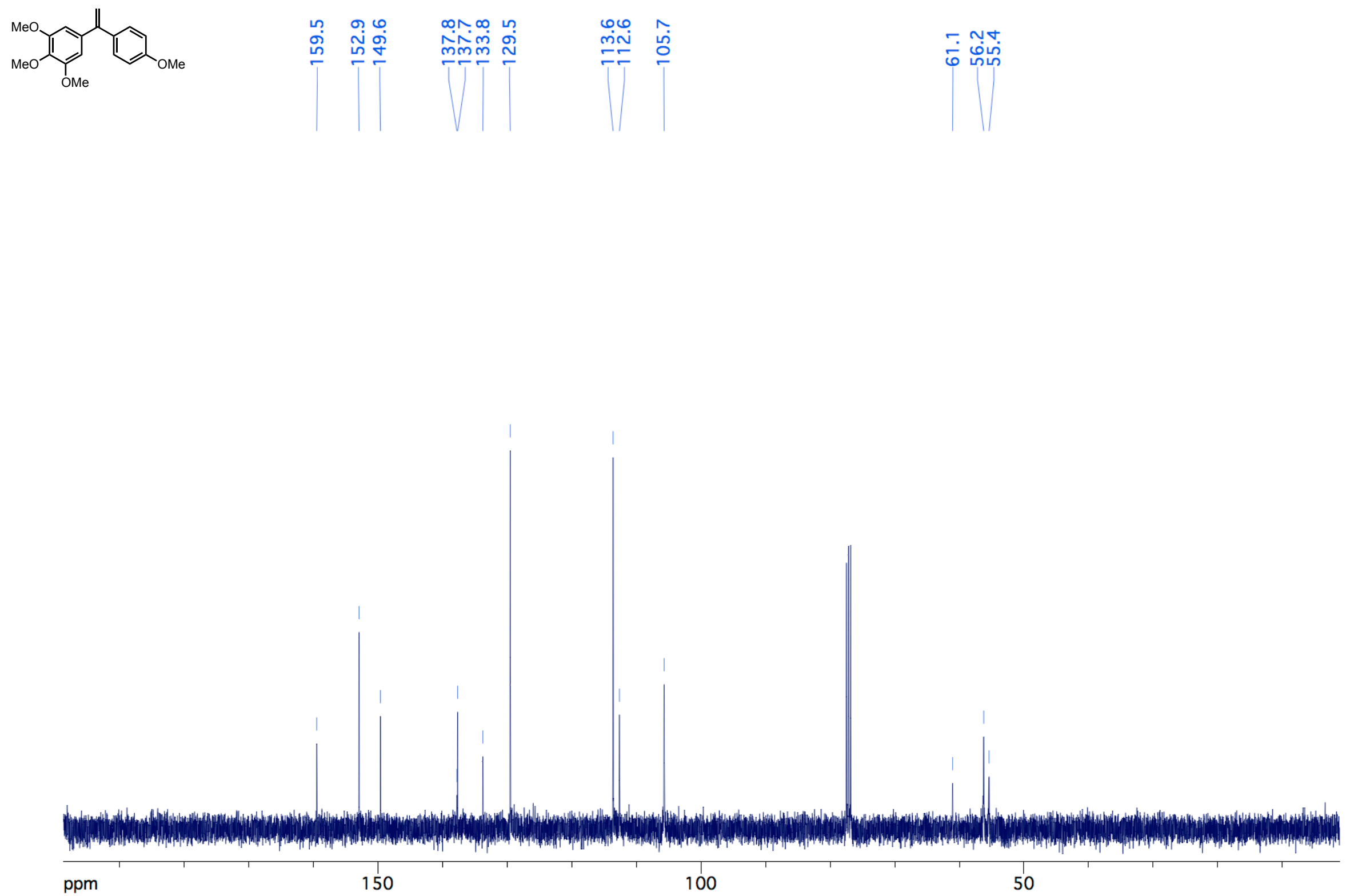
Prop-1-ene-1,1-diyldibenzene (20a) ${ }^{1} \mathrm{H} \mathrm{NMR}\left(\mathrm{CDCl}_{3}, 400 \mathrm{MHz}\right)$
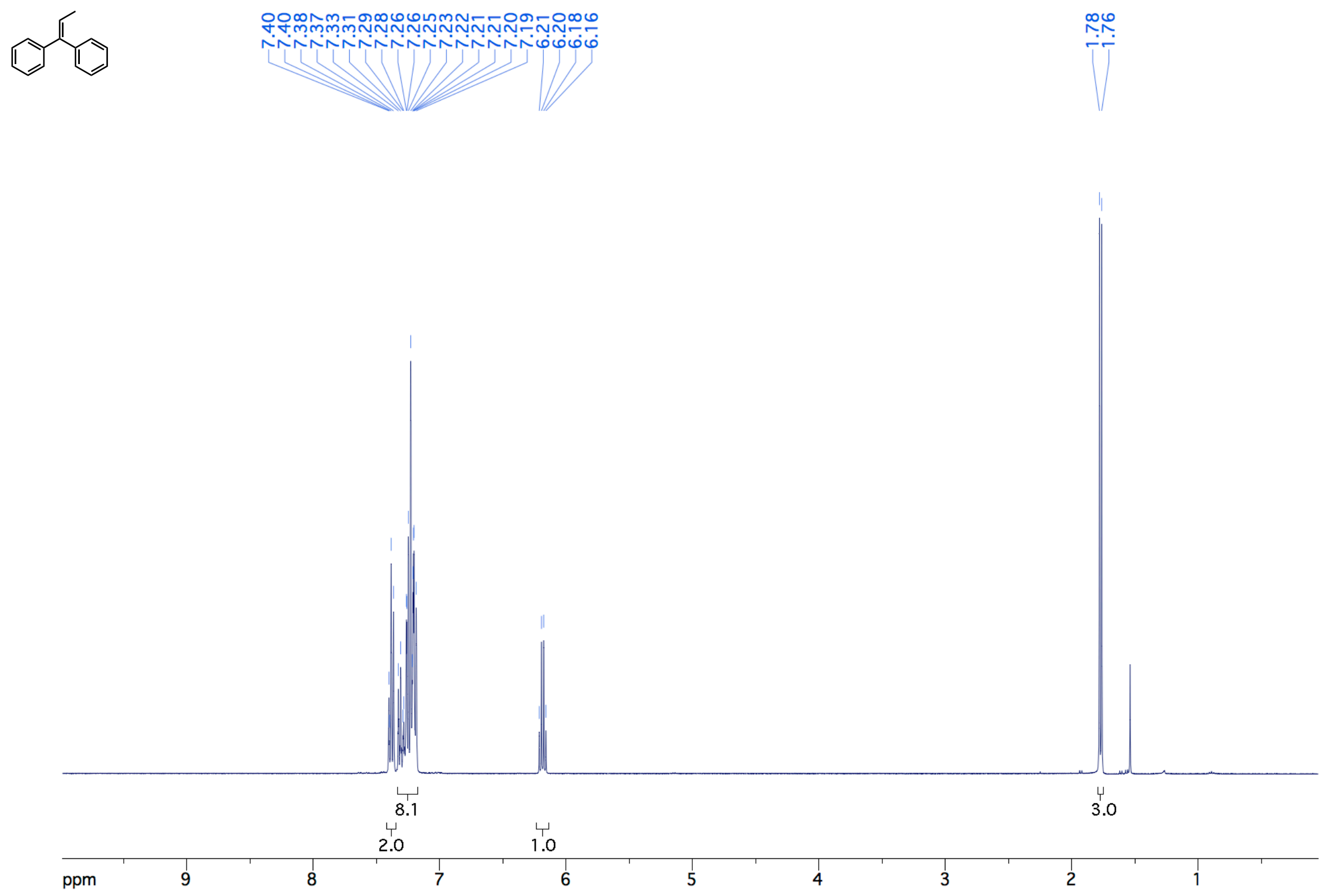

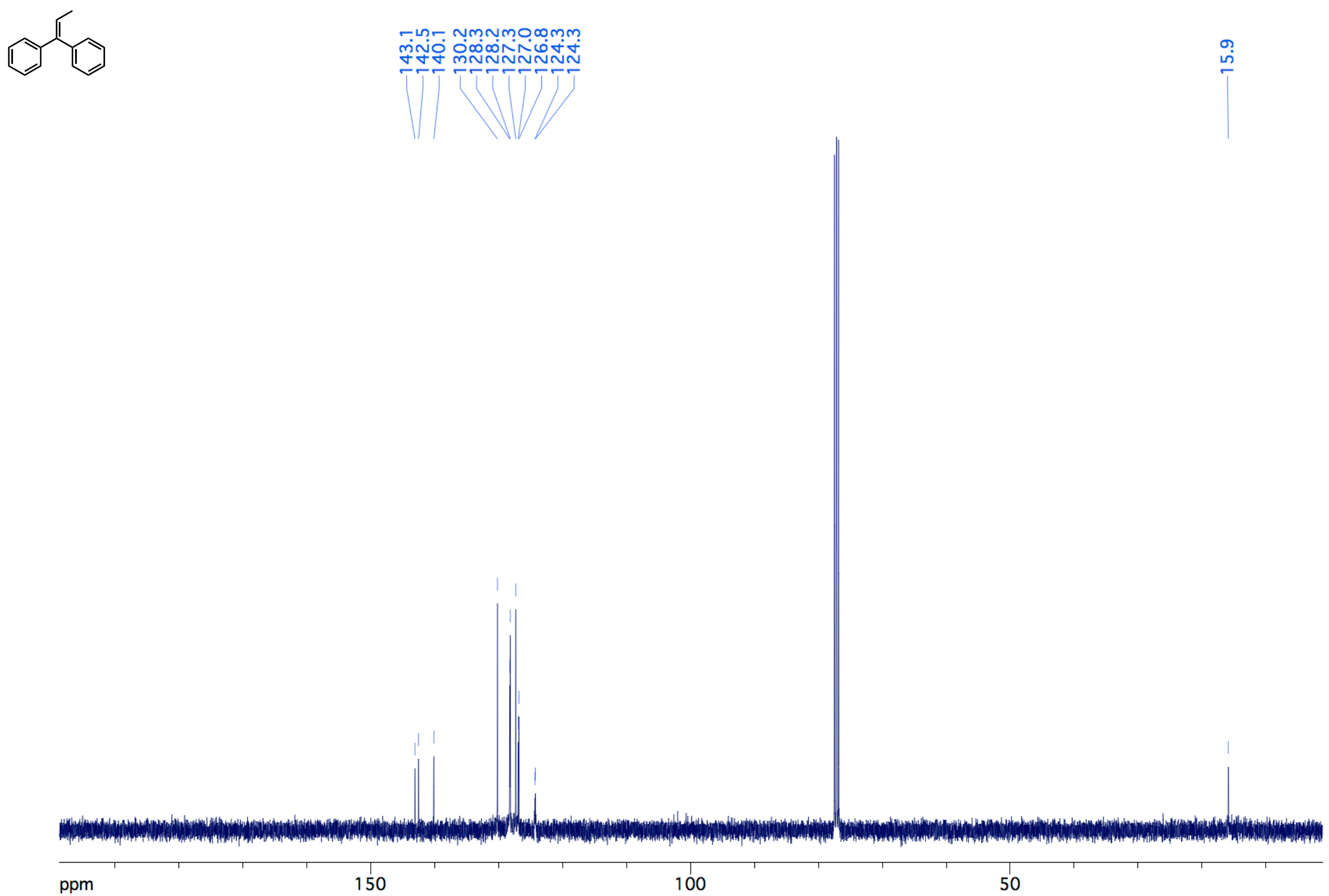
(1-Cyclohexylvinyl)benzene (21a)

${ }^{1} \mathrm{H} \mathrm{NMR}\left(\mathrm{CDCl}_{3}, 400 \mathrm{MHz}\right)$
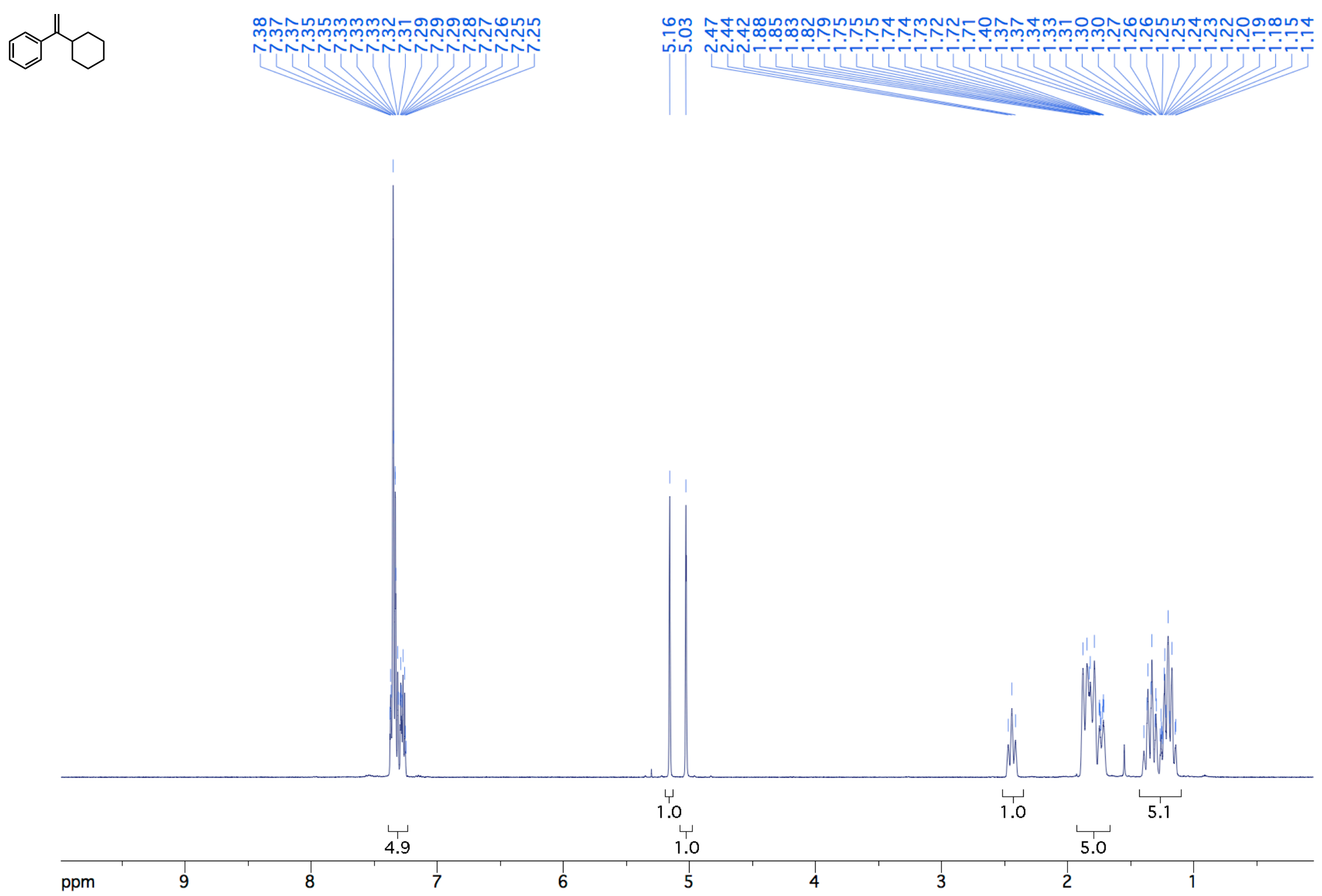

74 

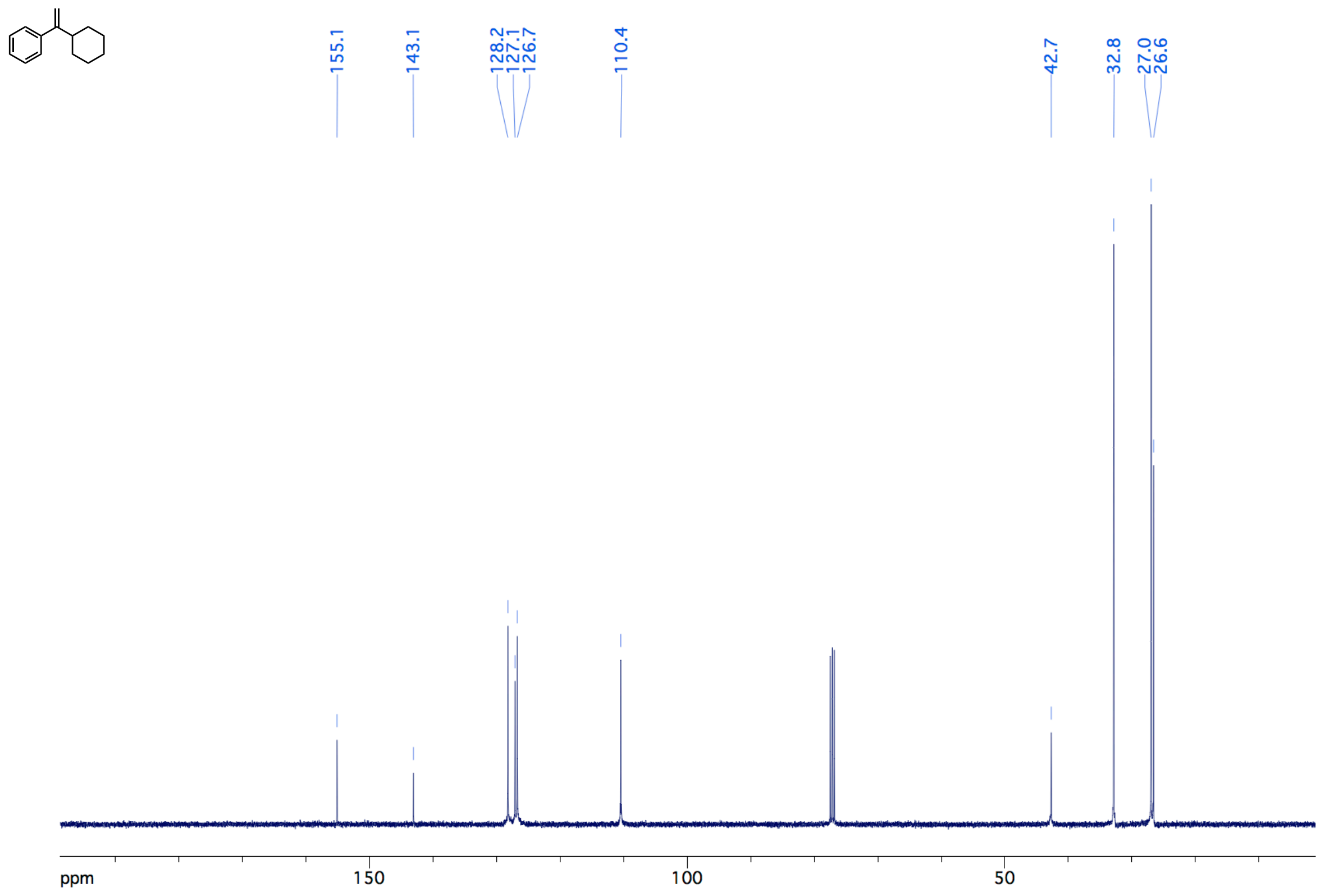


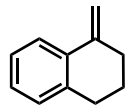

6egton Nivisinisin

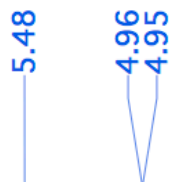

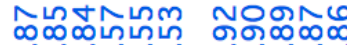
NNNNN r-r-

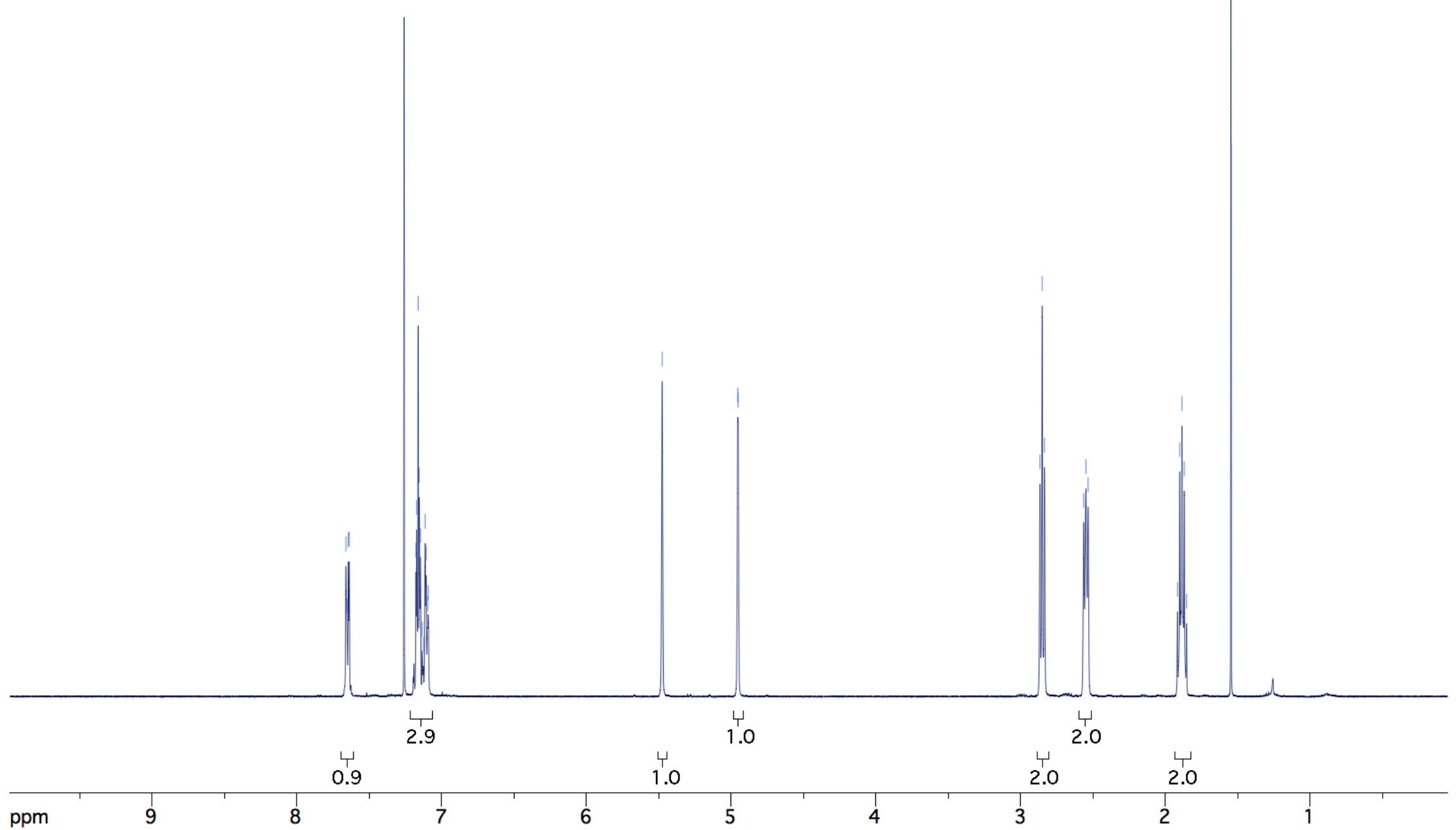



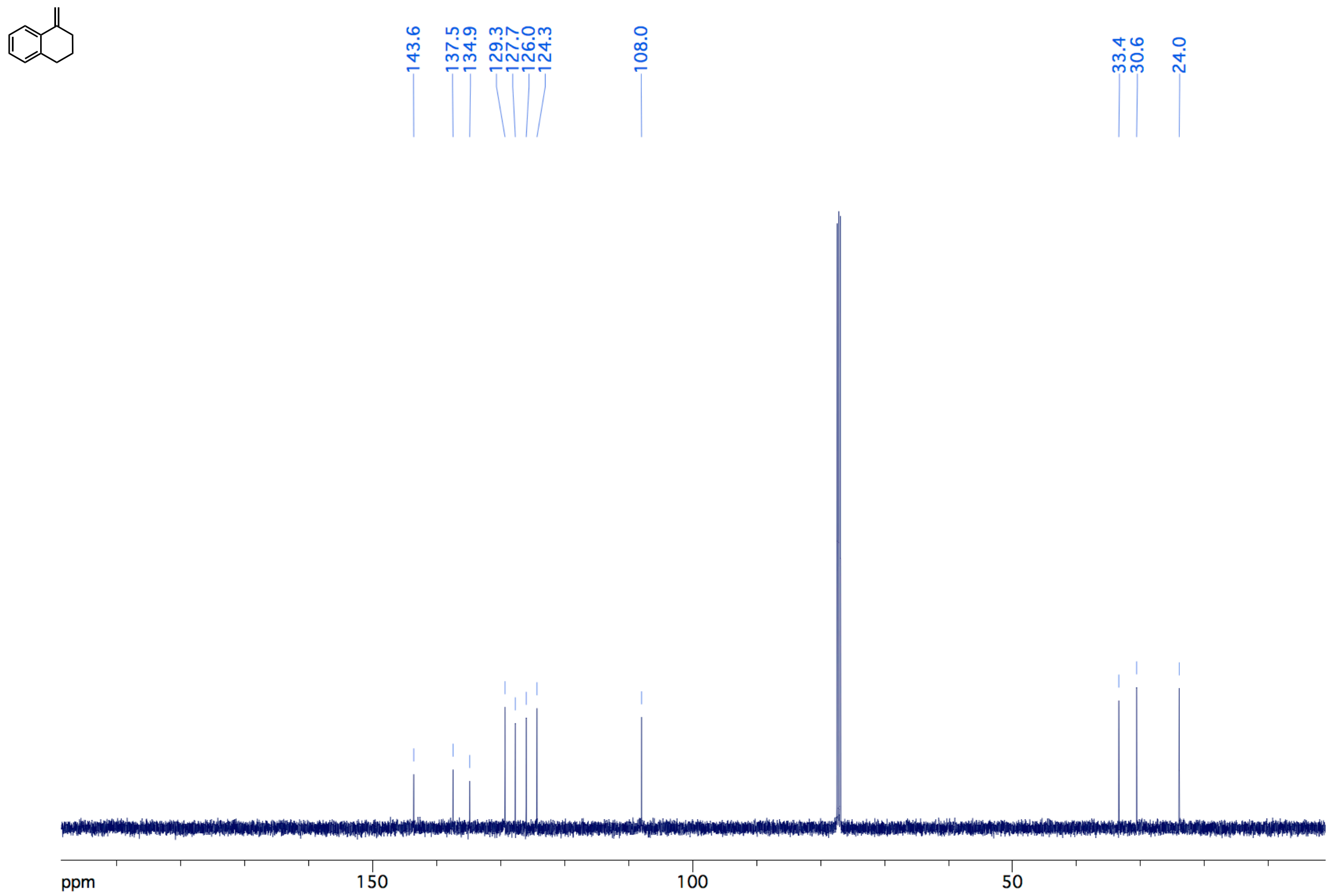


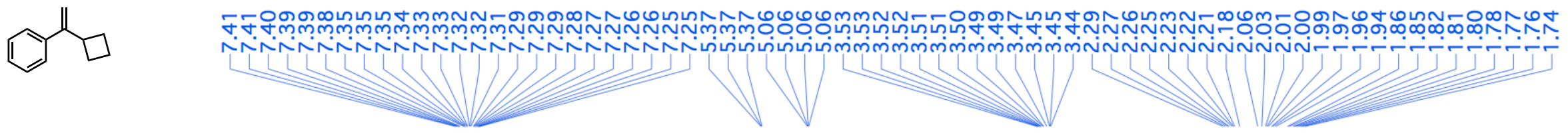

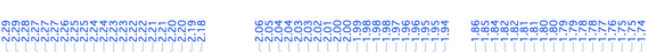

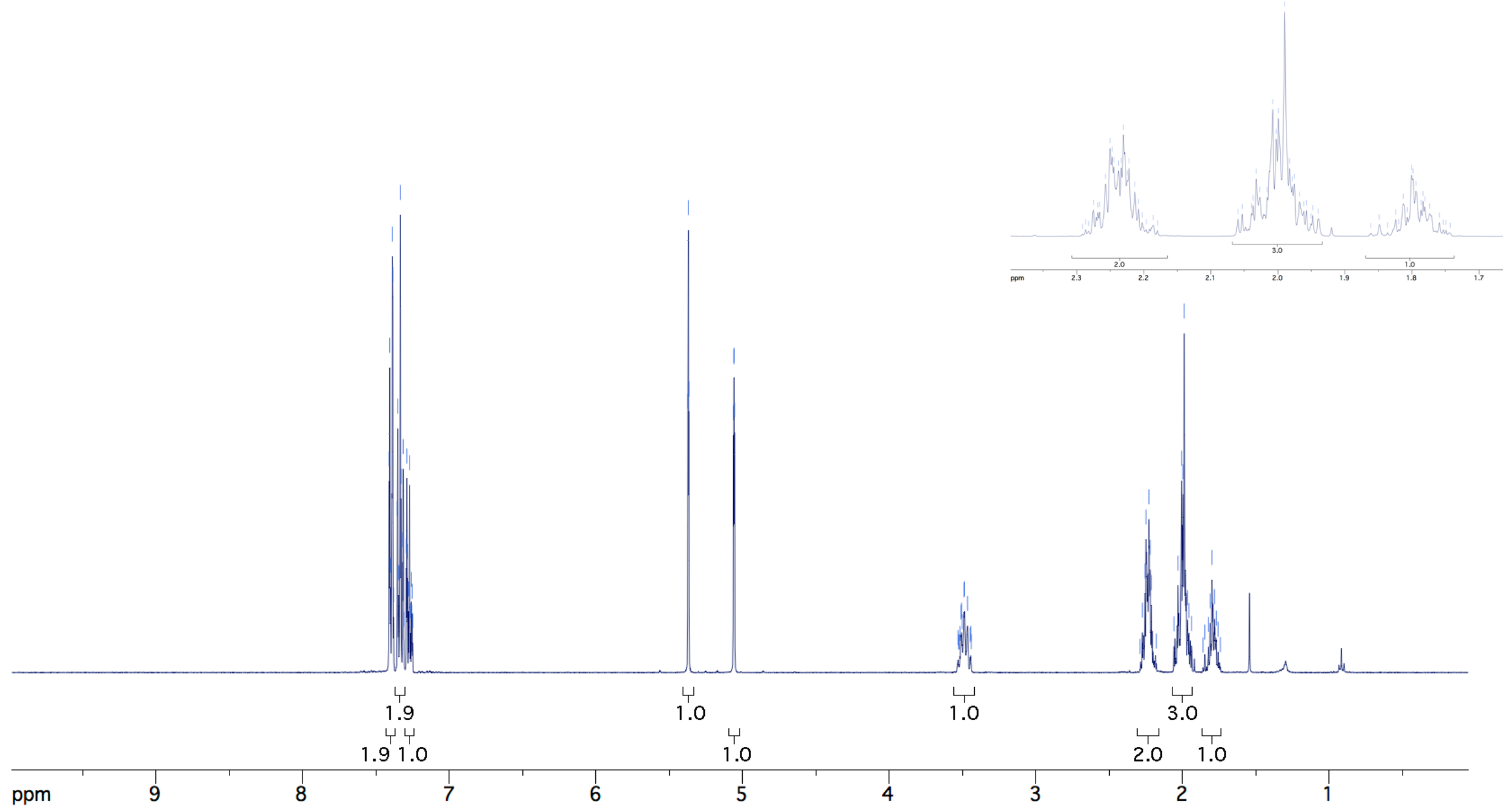



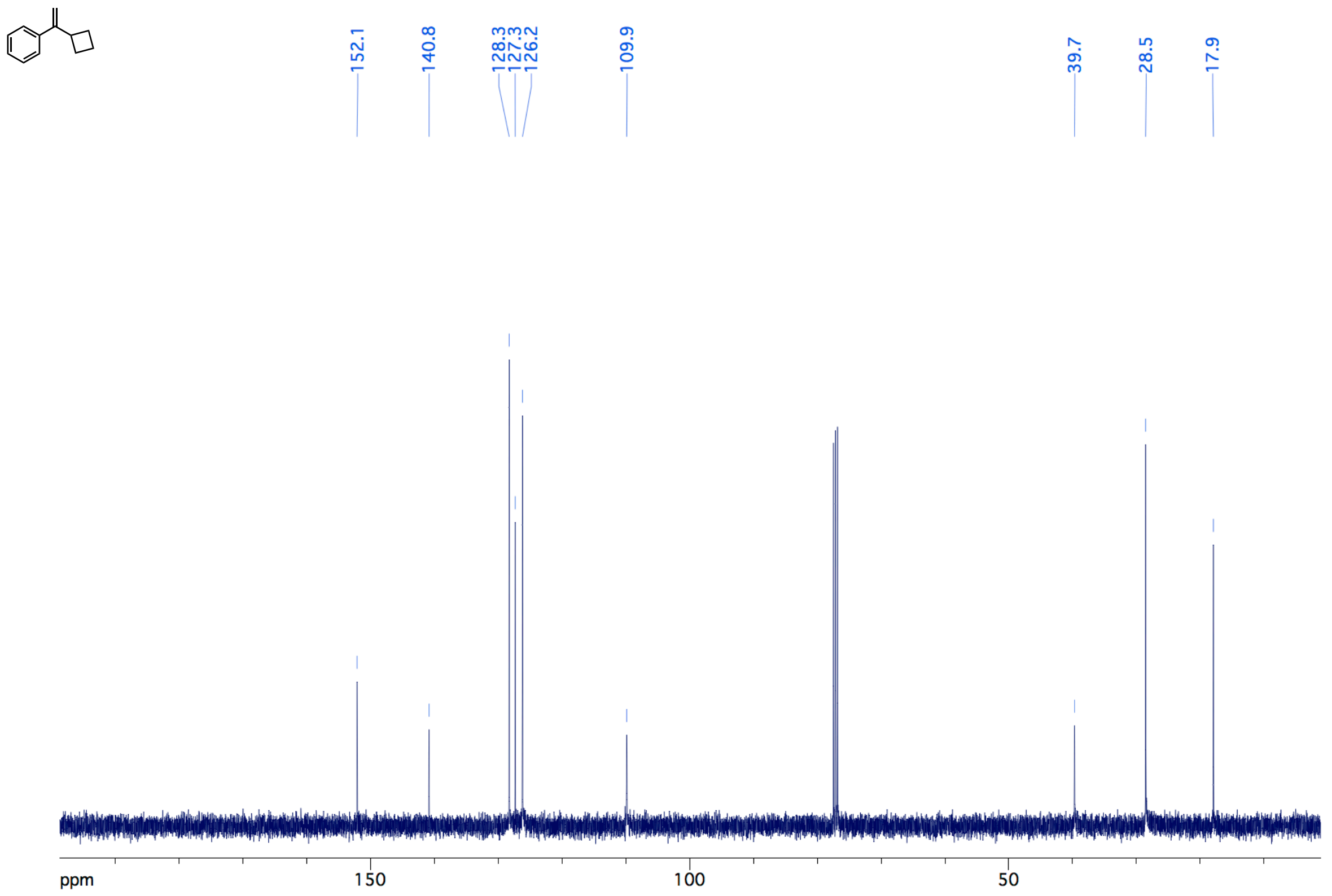
(1-Phenylvinyl)cyclooctane (24a)

${ }^{1} \mathrm{H} \mathrm{NMR}\left(\mathrm{CDCl}_{3}, 400 \mathrm{MHz}\right)$
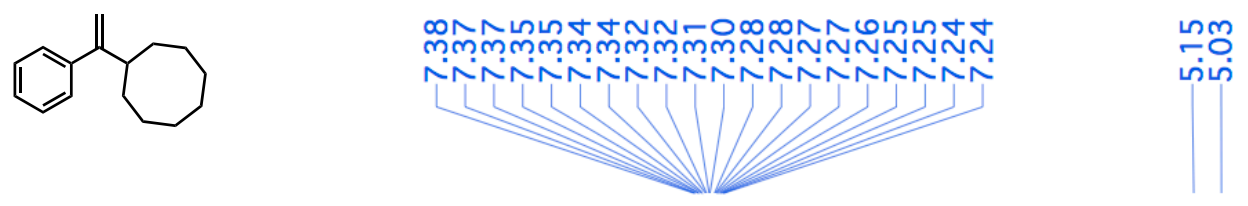
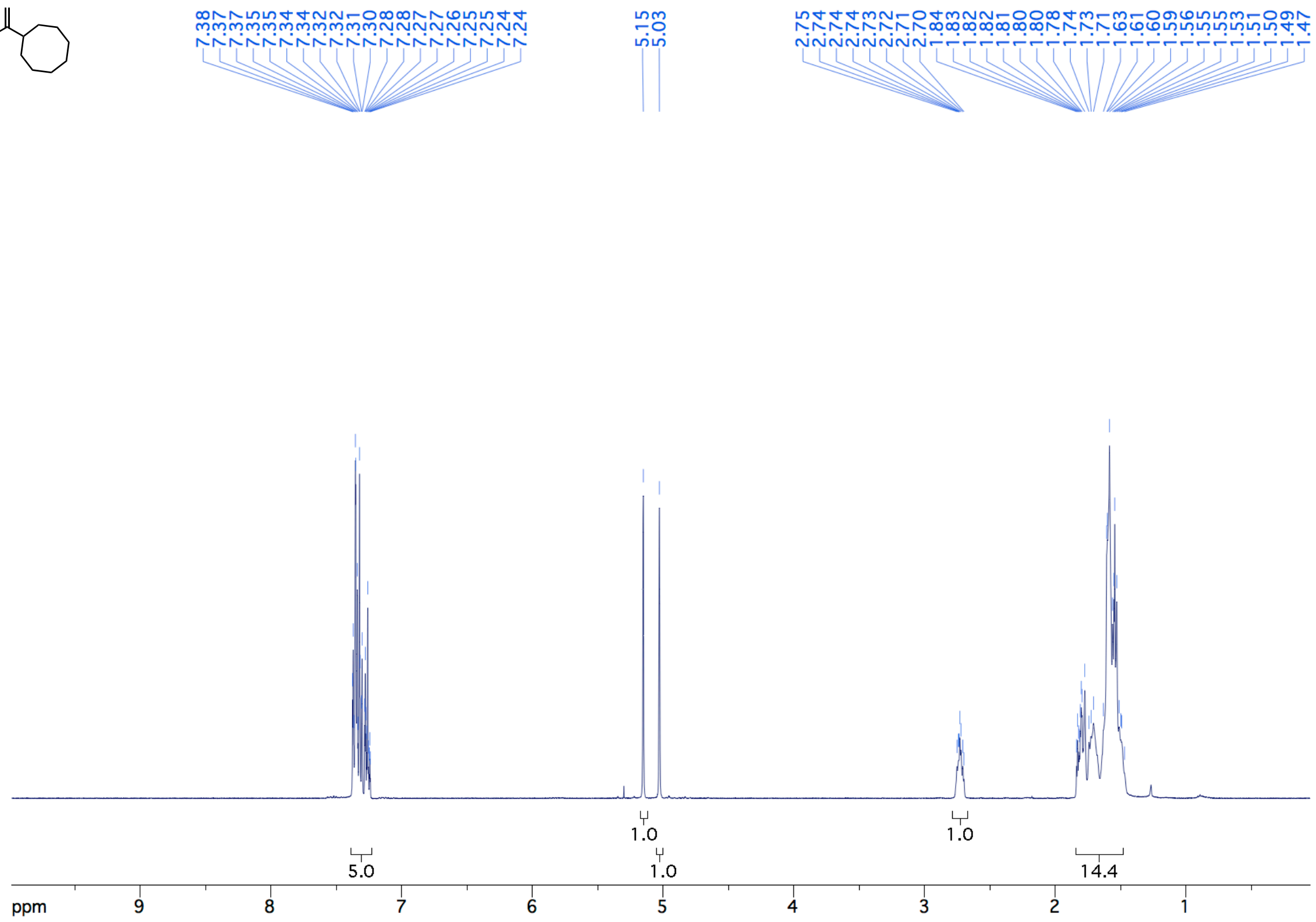

80 

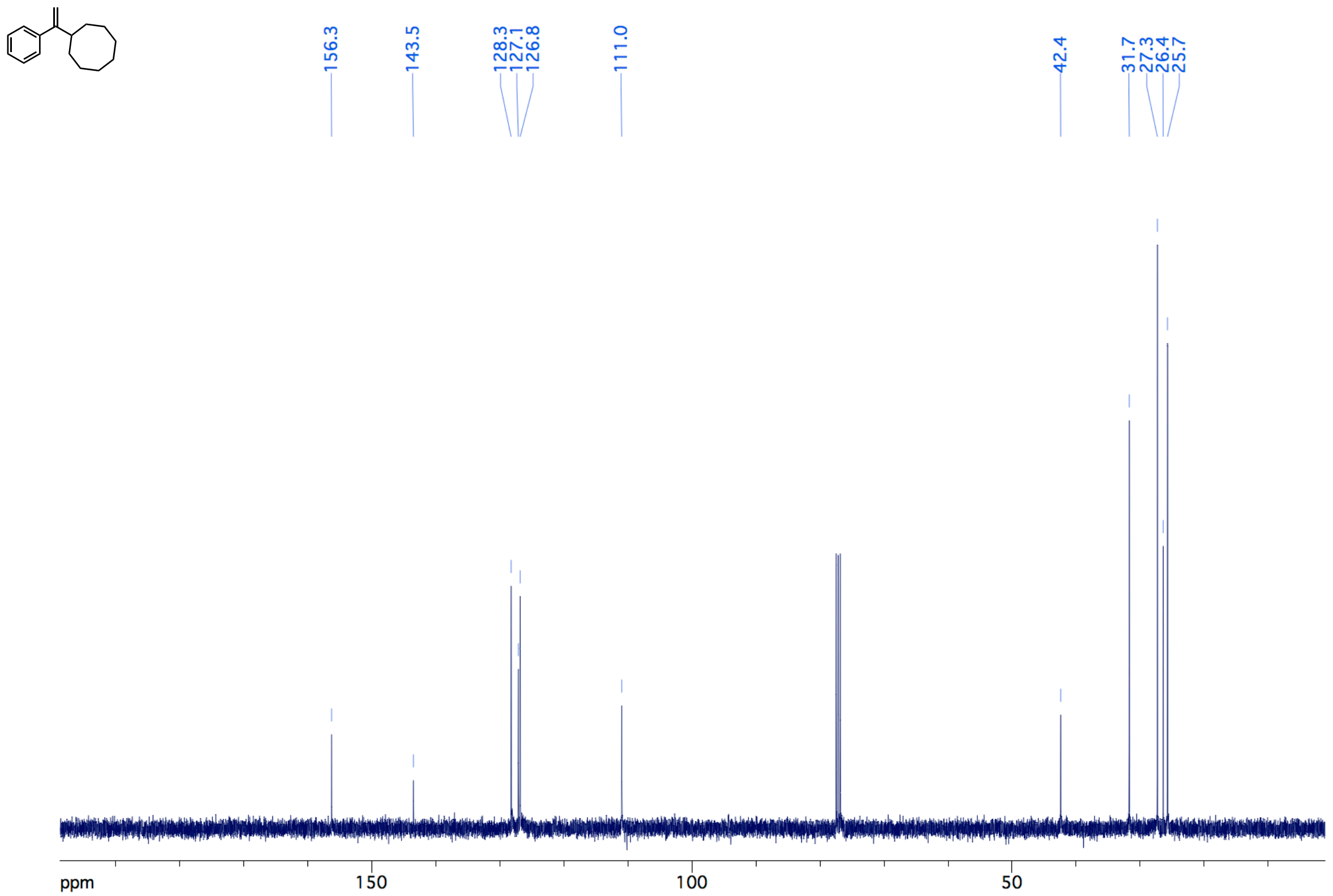
${ }^{1} \mathrm{H} \mathrm{NMR}\left(\mathrm{CDCl}_{3}, 400 \mathrm{MHz}\right)$

110

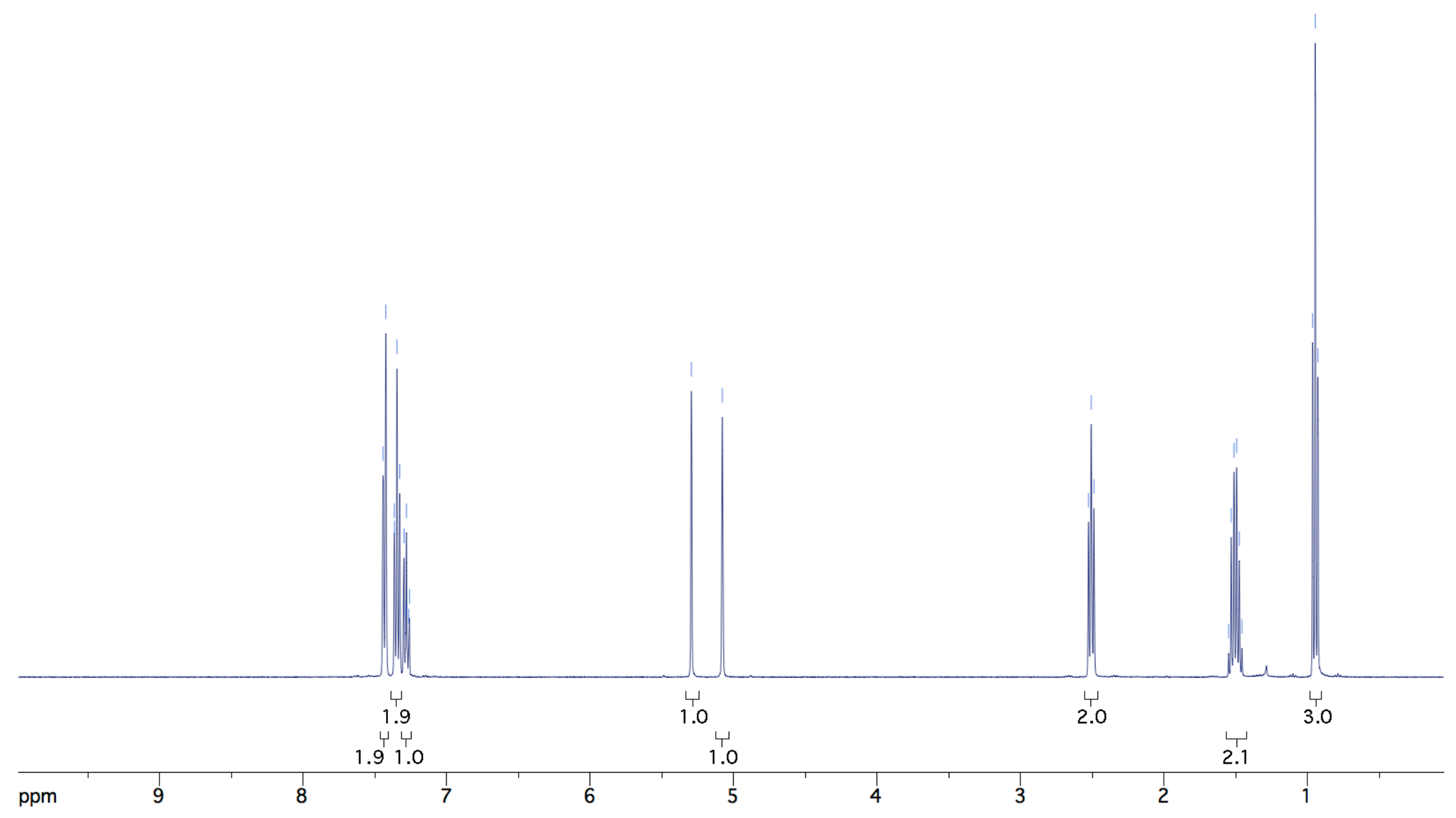



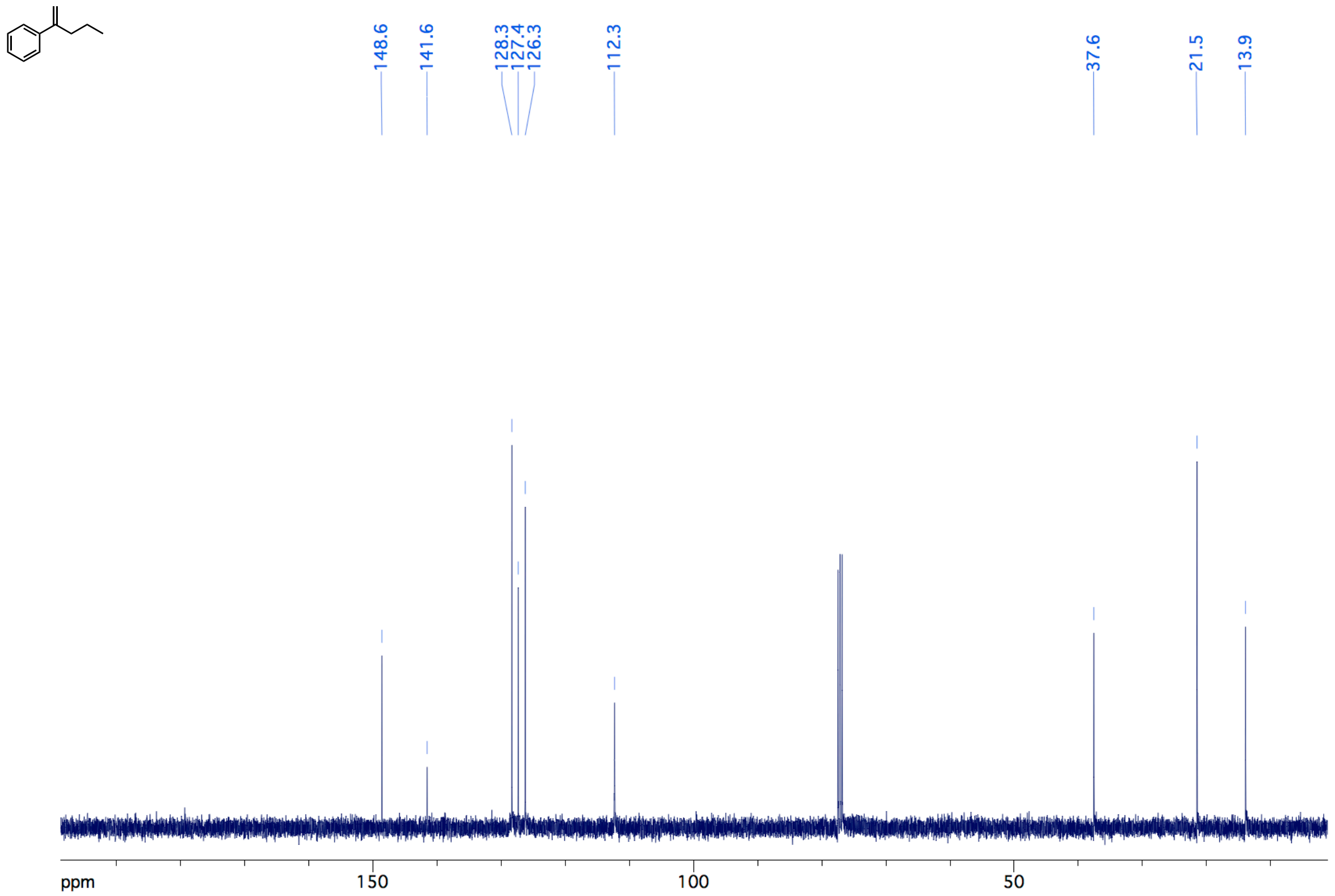
(3-Methylbut-1-en-2-yl)benzene (26a) ${ }^{1} \mathrm{H} \mathrm{NMR}\left(\mathrm{CDCl}_{3}, 400 \mathrm{MHz}\right)$

10.
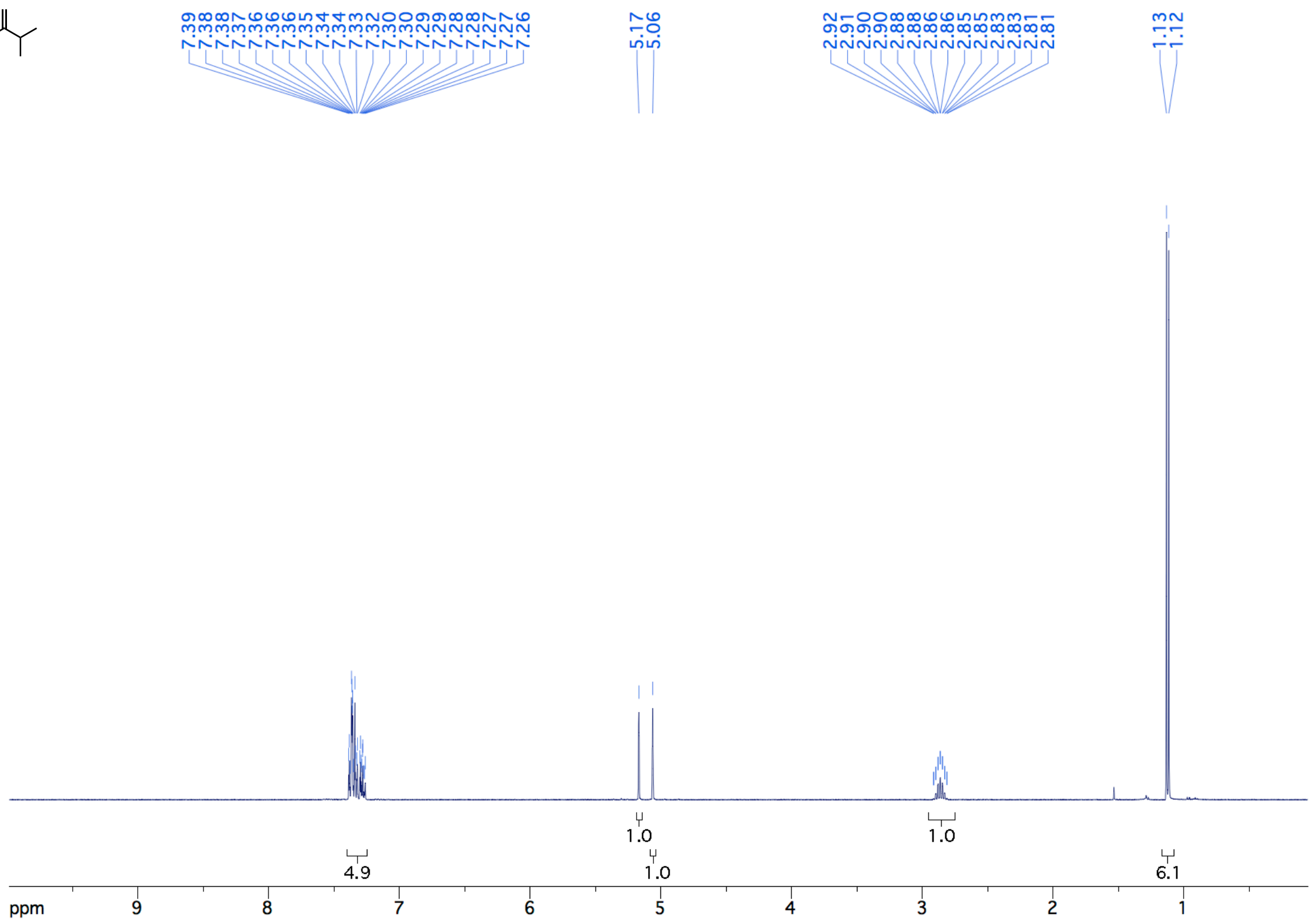

84 
(3-Methylbut-1-en-2-yl)benzene (26a) ${ }^{13} \mathrm{C} \mathrm{NMR}\left(\mathrm{CDCl}_{3}, 100 \mathrm{MHz}\right)$
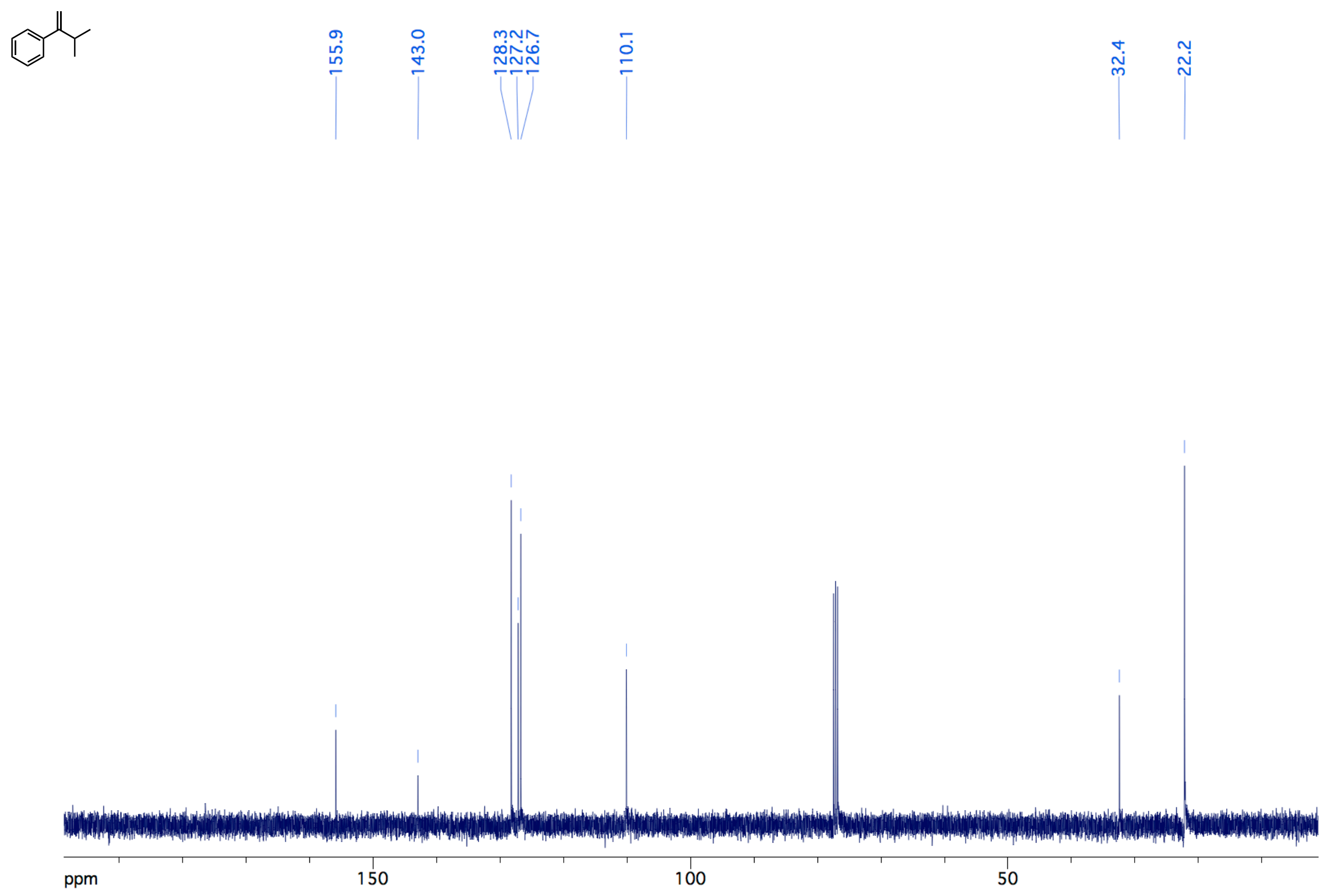

85 
Hept-1-en-2-ylbenzene (27a) ${ }^{1} \mathrm{H}$ NMR $\left(\mathrm{CDCl}_{3}, 400 \mathrm{MHz}\right)$

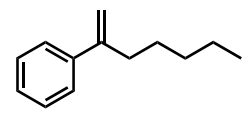

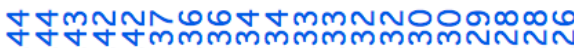

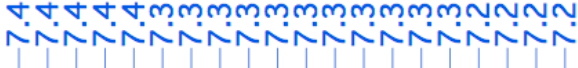

ஸึ⿵冂⿰氵亡

ท่เท่นเ

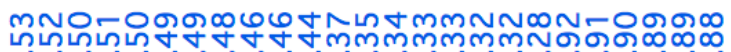

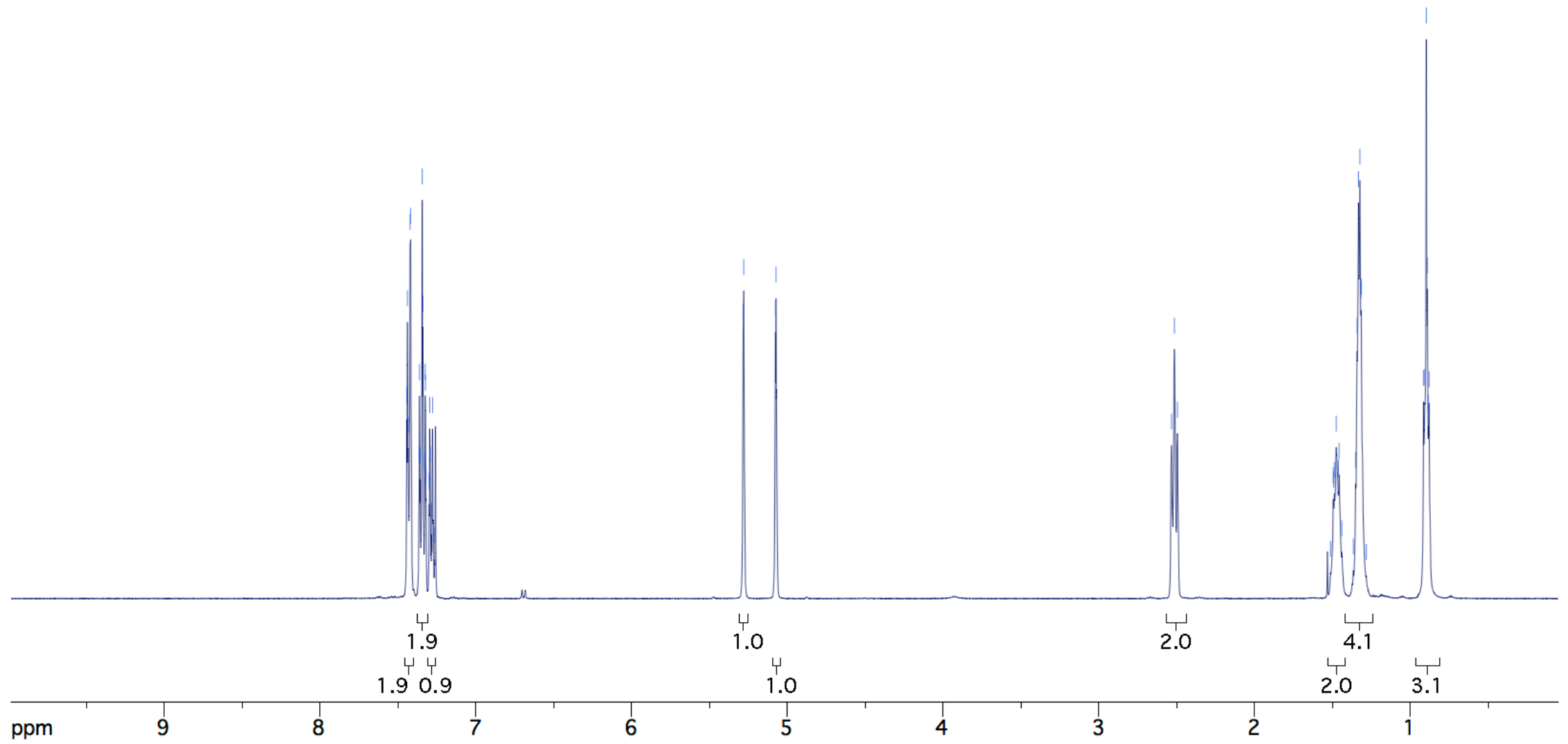



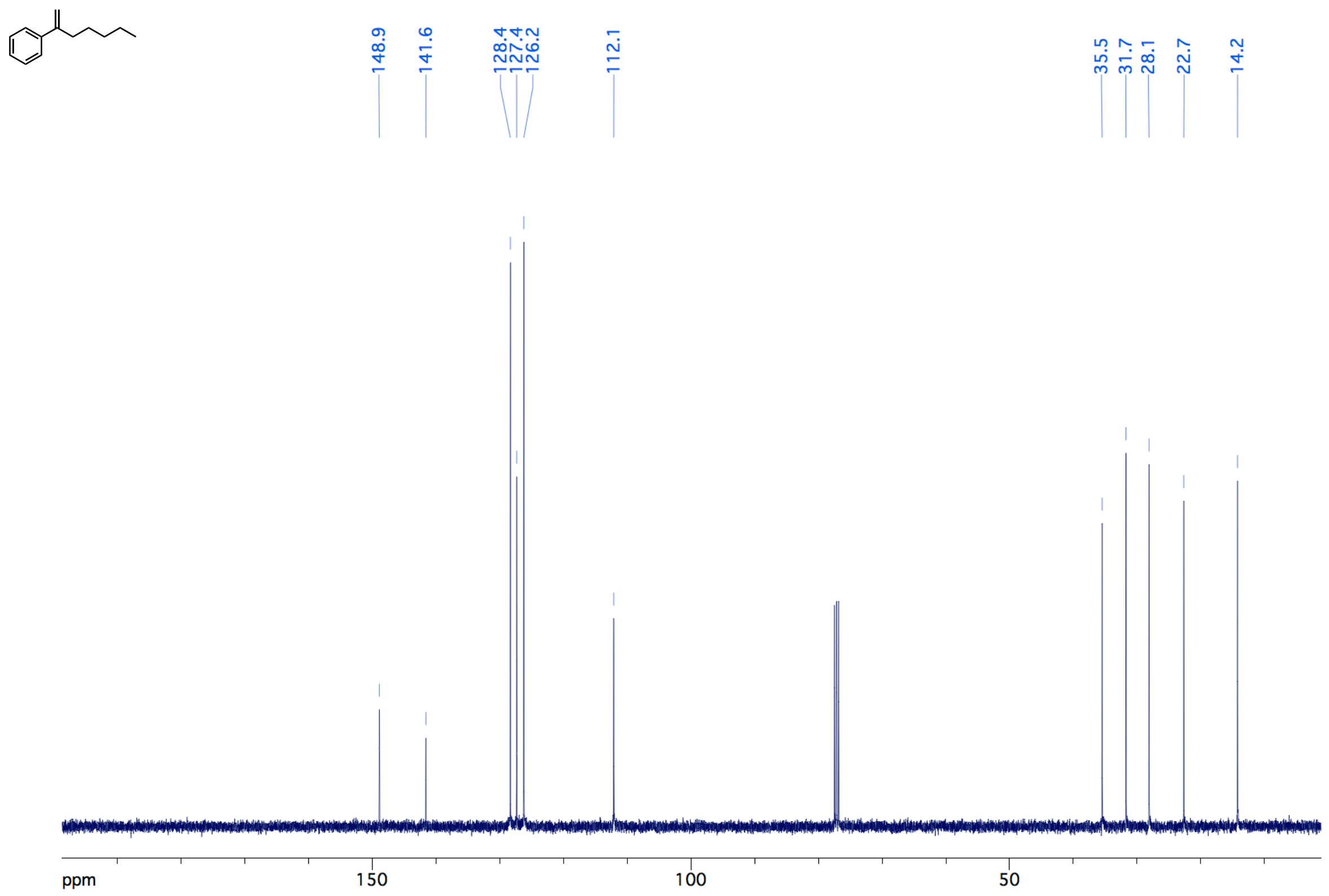

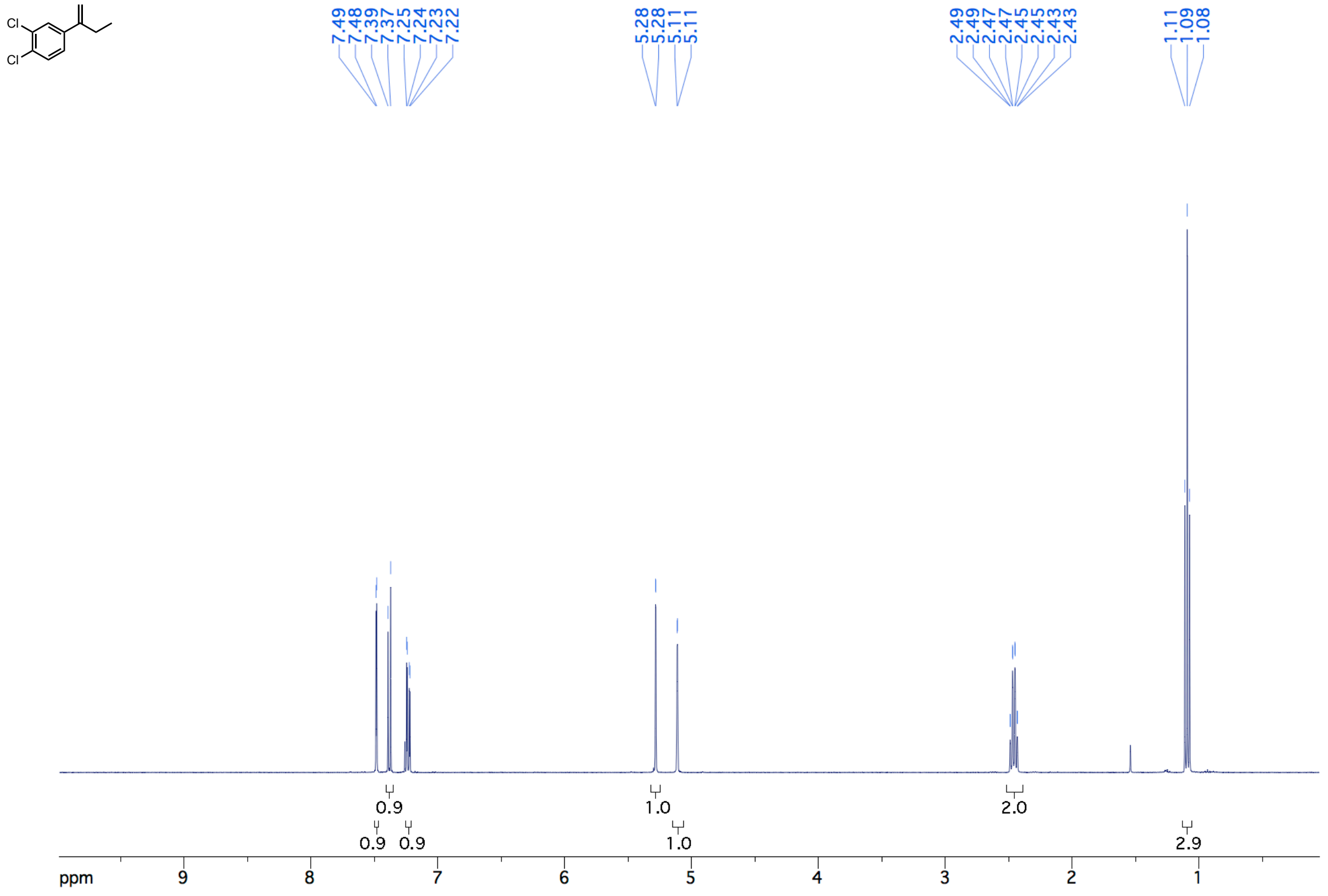

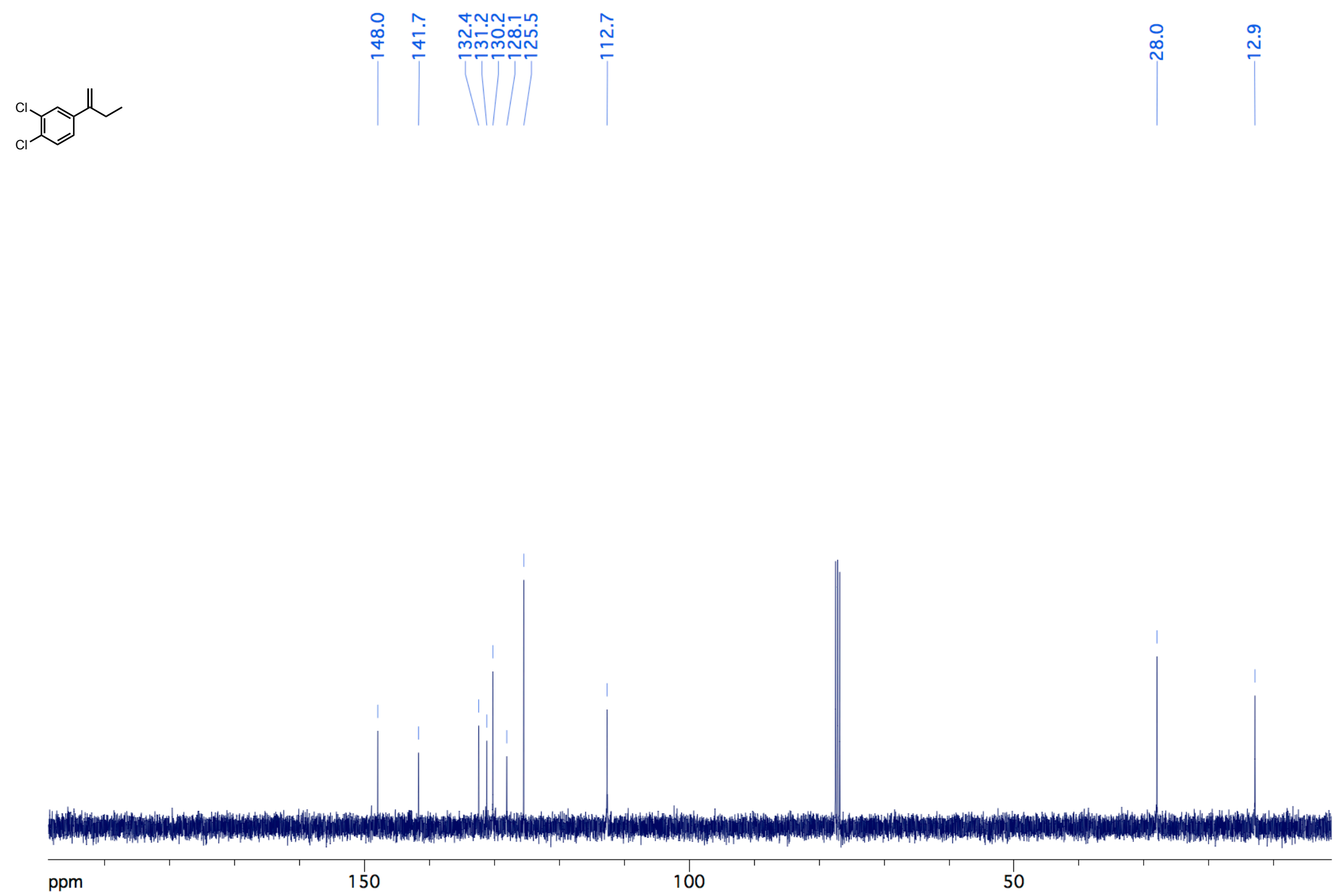


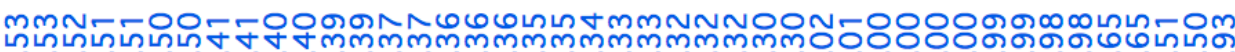

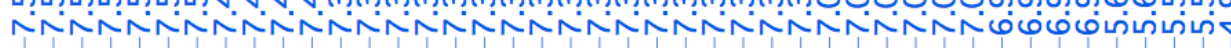<smiles>C=C(COc1ccccc1)c1ccccc1</smiles>

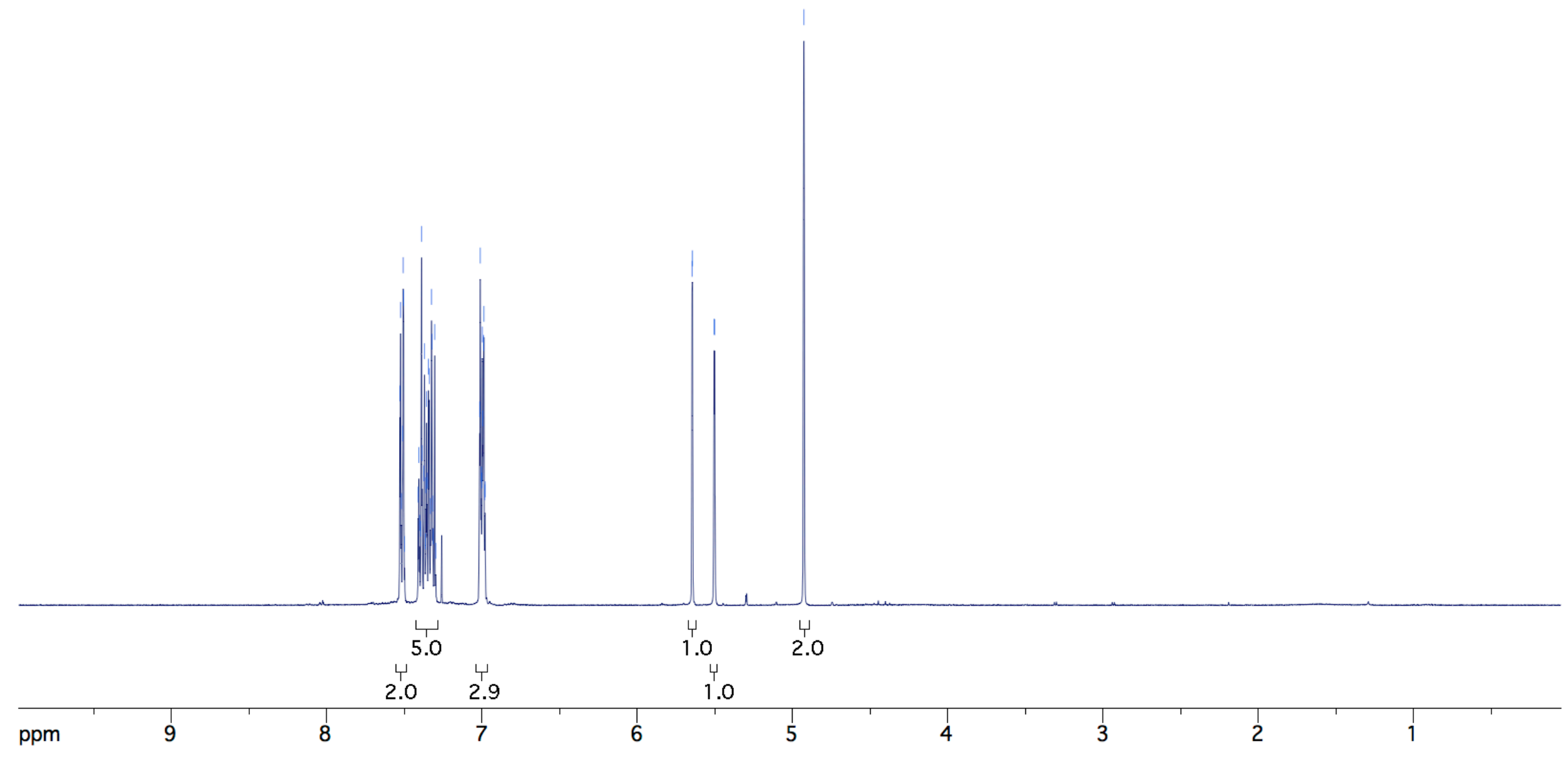




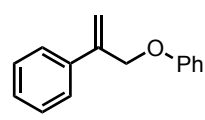

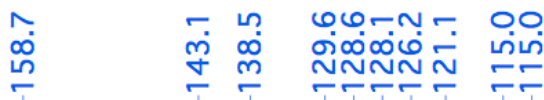

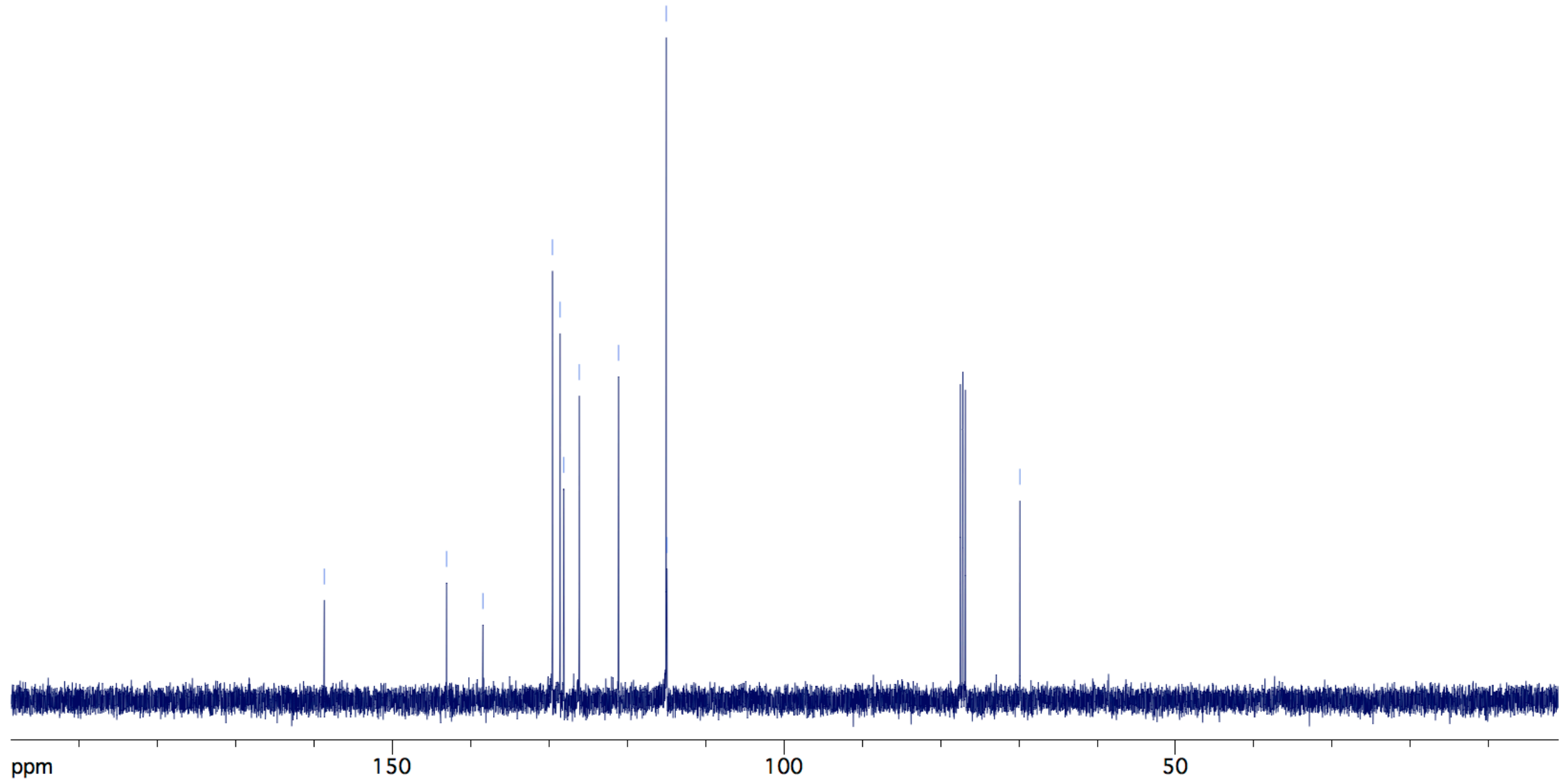



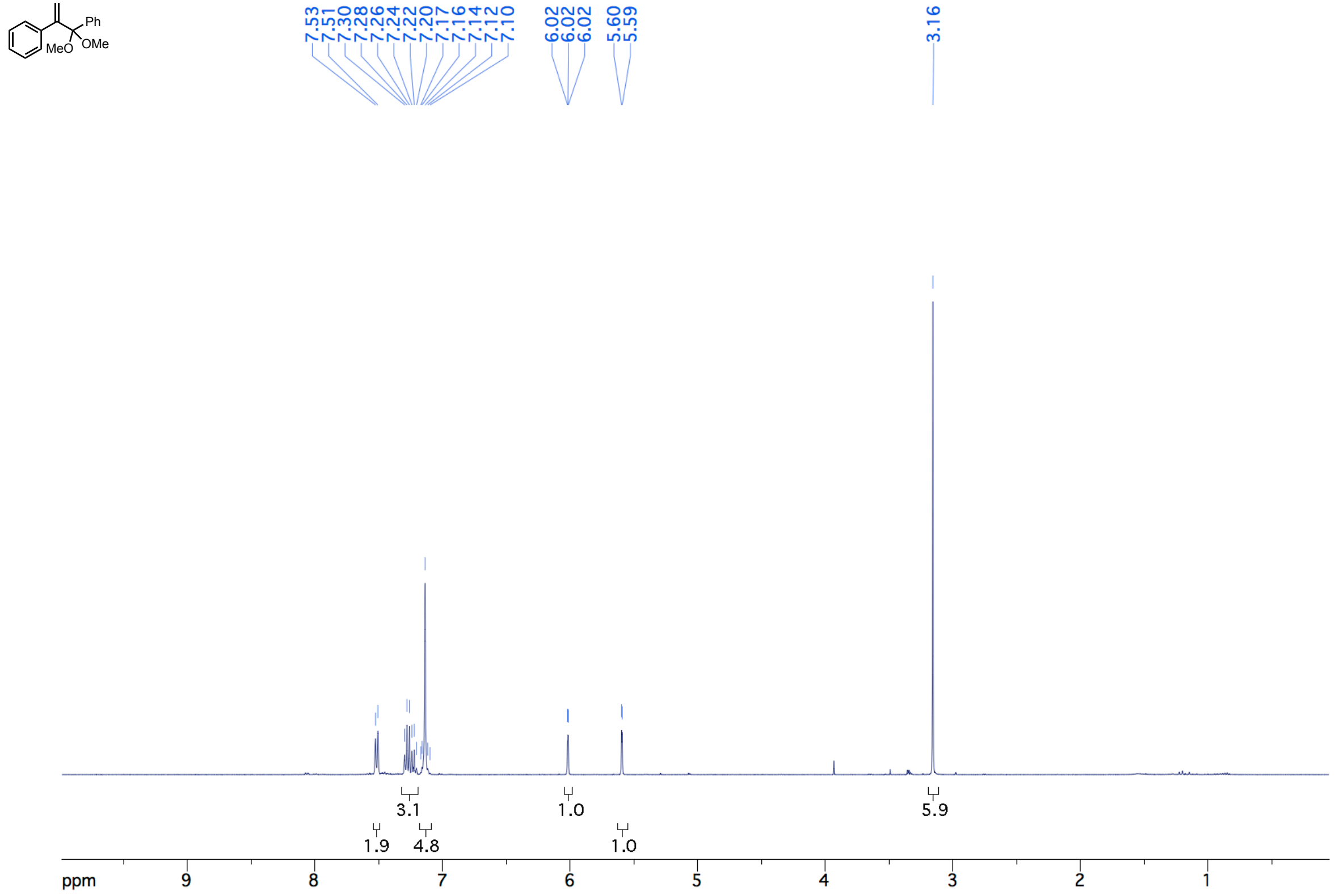

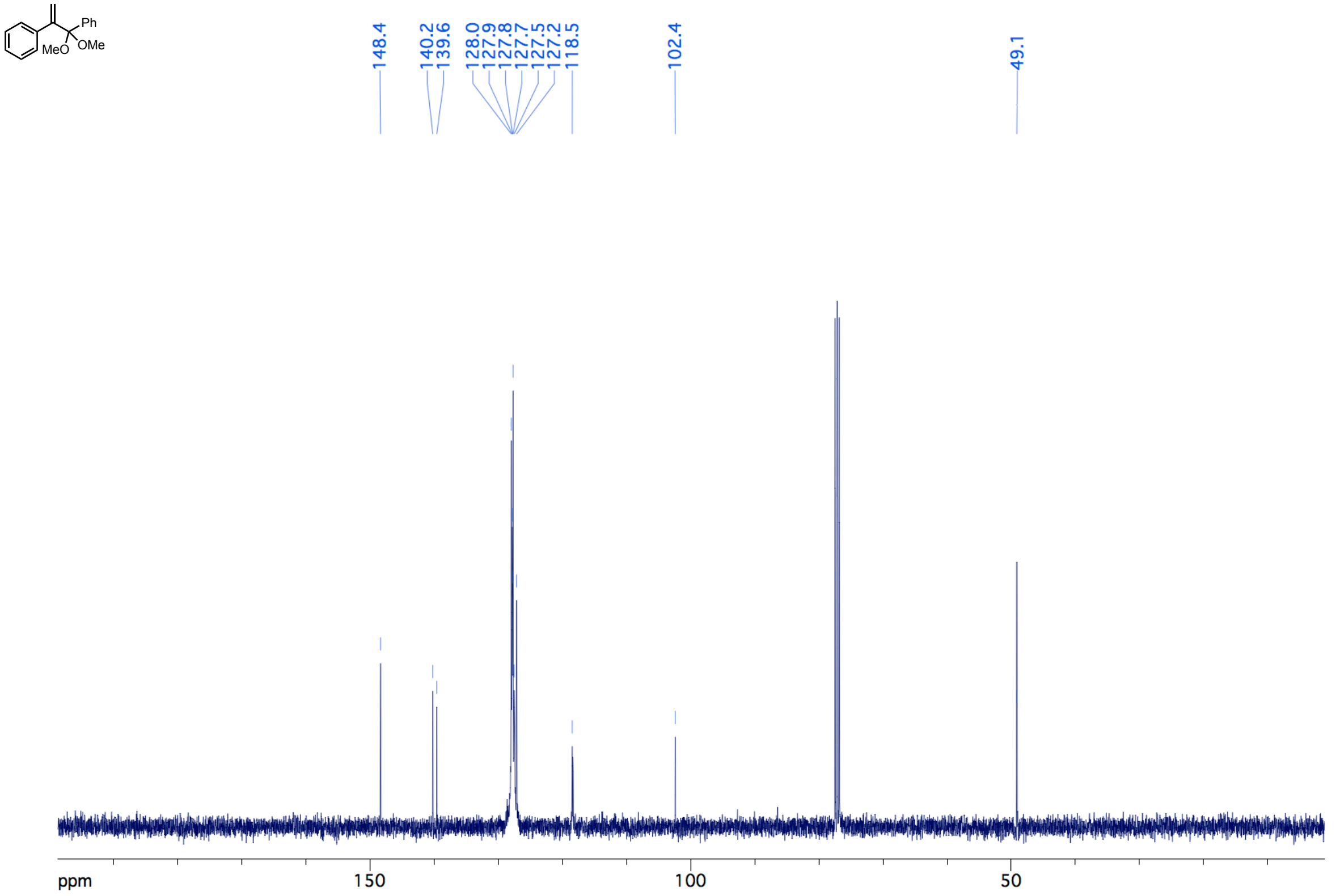

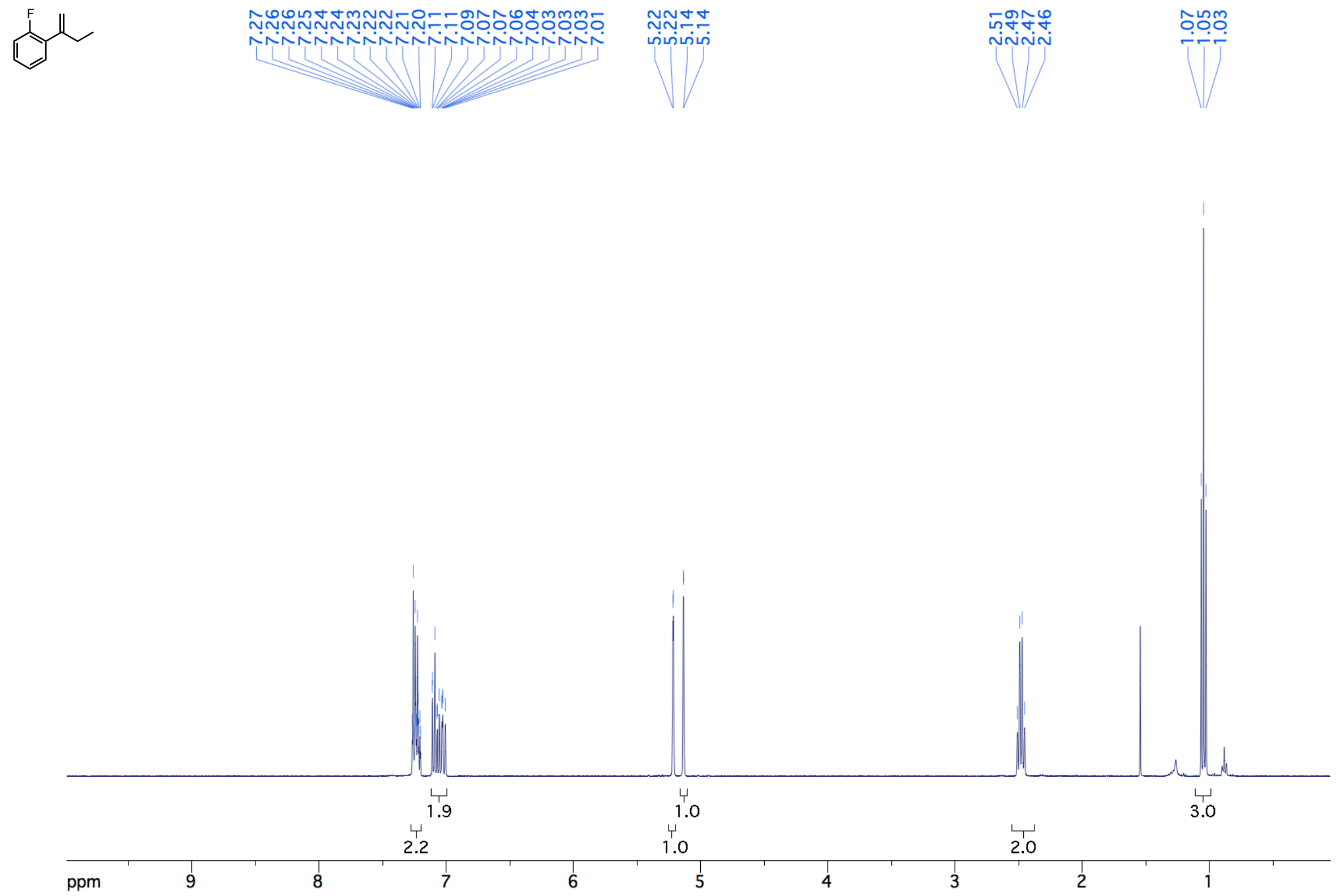

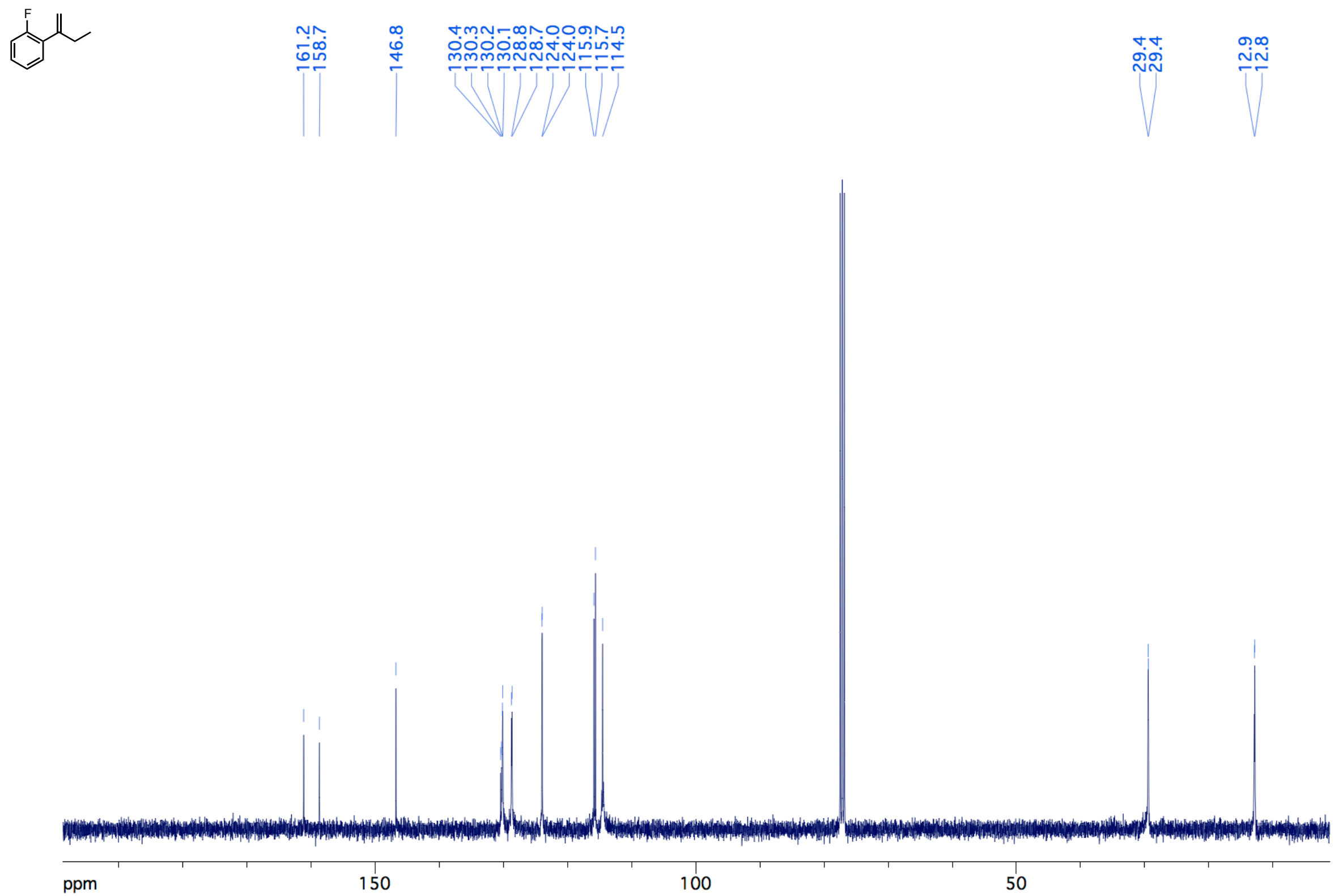
1-(But-1-en-2-yl)-2-fluorobenzene (31a) ${ }^{19} \mathrm{~F}-\mathrm{NMR}\left(\mathrm{CDCl}_{3}, 376 \mathrm{MHz}\right)$
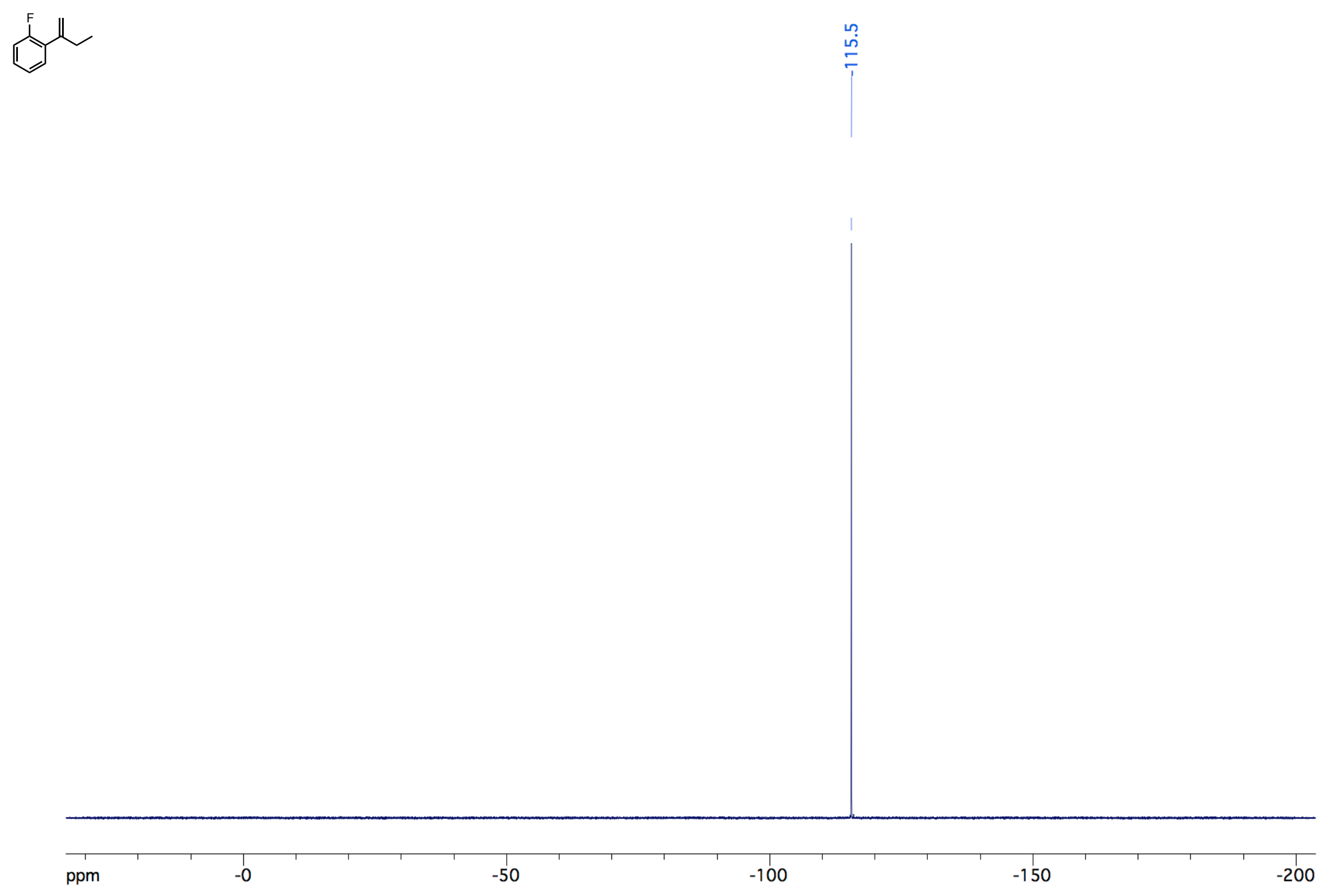
2-(Prop-1-en-2-yl)naphthalene (32a) ${ }^{1} \mathrm{H} \mathrm{NMR}\left(\mathrm{CDCl}_{3}, 400 \mathrm{MHz}\right)$

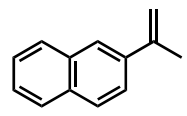

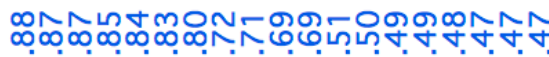

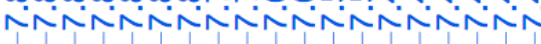

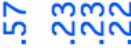

ค่ เ่ต่บน

ల్లిల్లిల్

NกNก

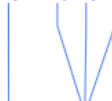

(1)

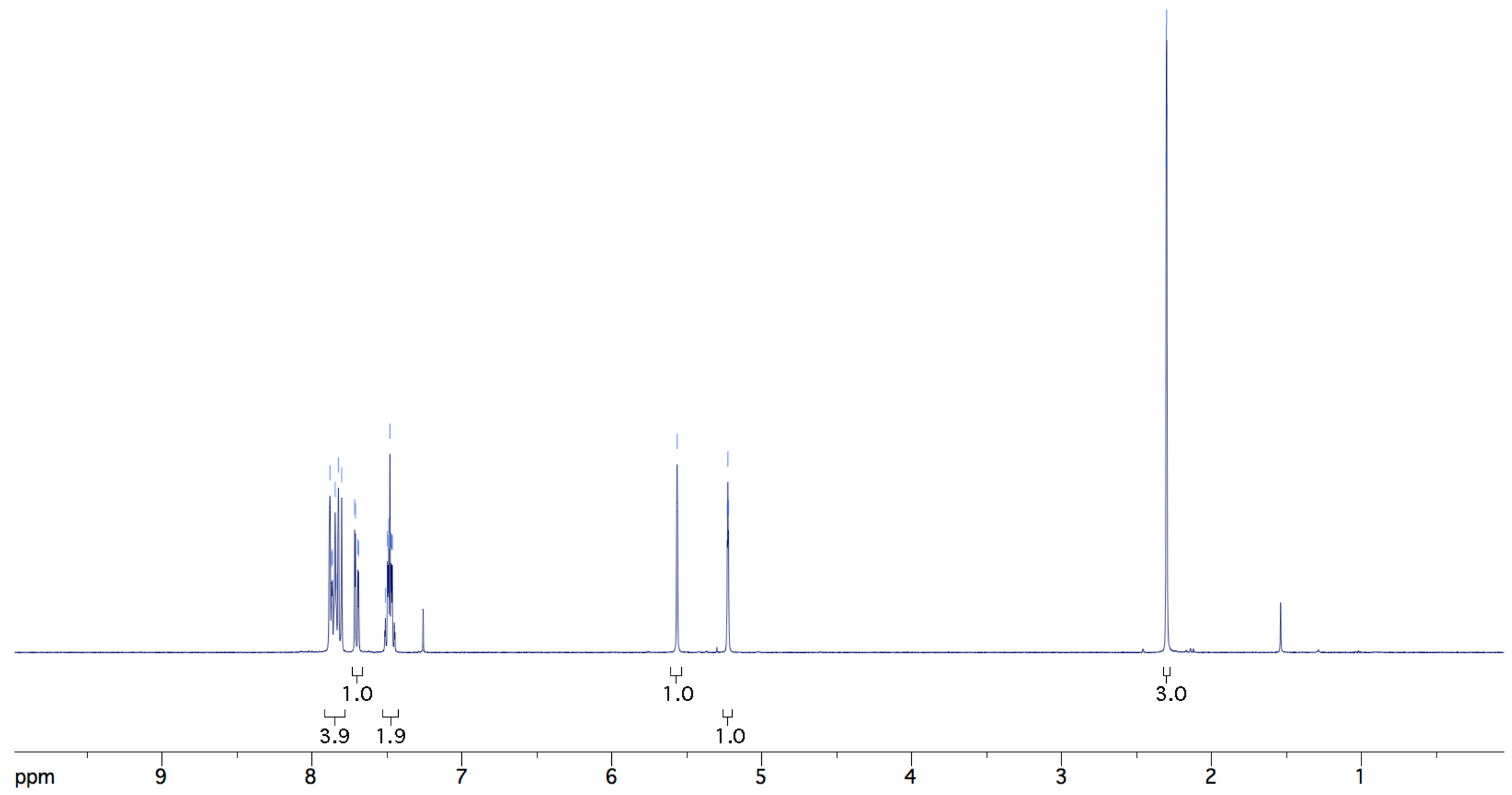



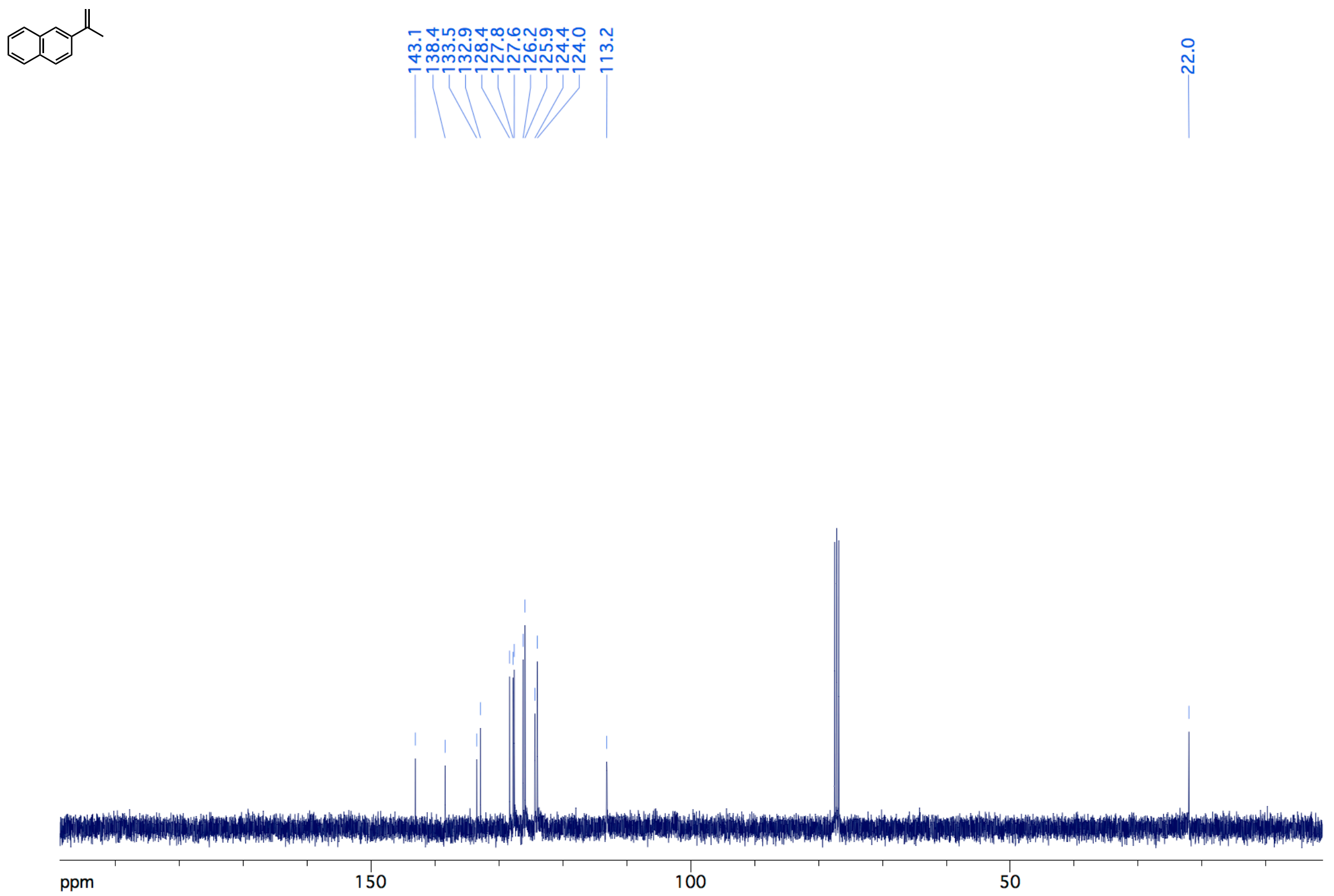
4'-Methoxy-3-vinyl-1,1'-biphenyl (33a) ${ }^{1} \mathrm{H} \mathrm{NMR}\left(\mathrm{CDCl}_{3}, 400 \mathrm{MHz}\right)$

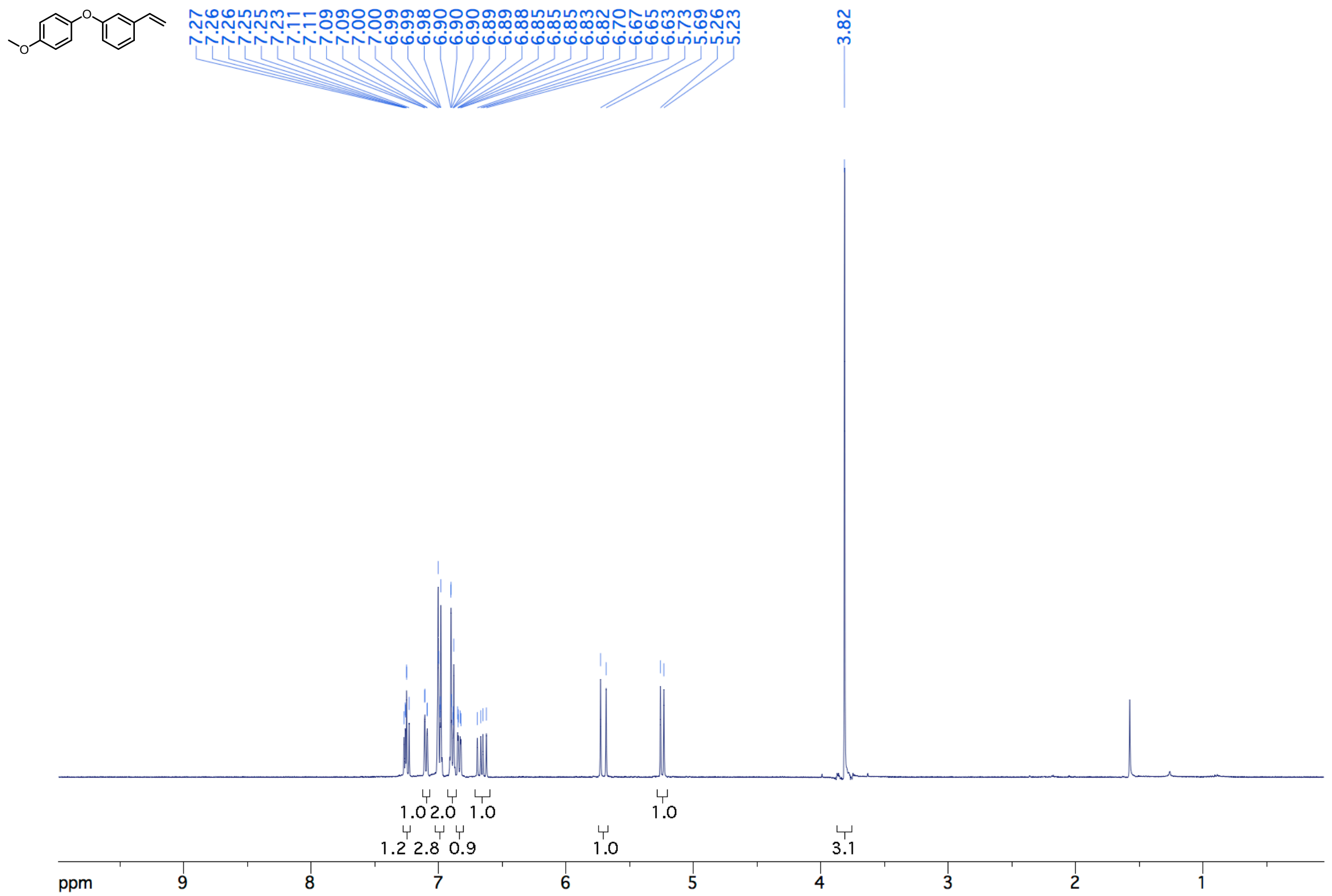


4'-Methoxy-3-vinyl-1,1'-biphenyl (33a) ${ }^{13} \mathrm{C} \mathrm{NMR}\left(\mathrm{CDCl}_{3}, 100 \mathrm{MHz}\right)$
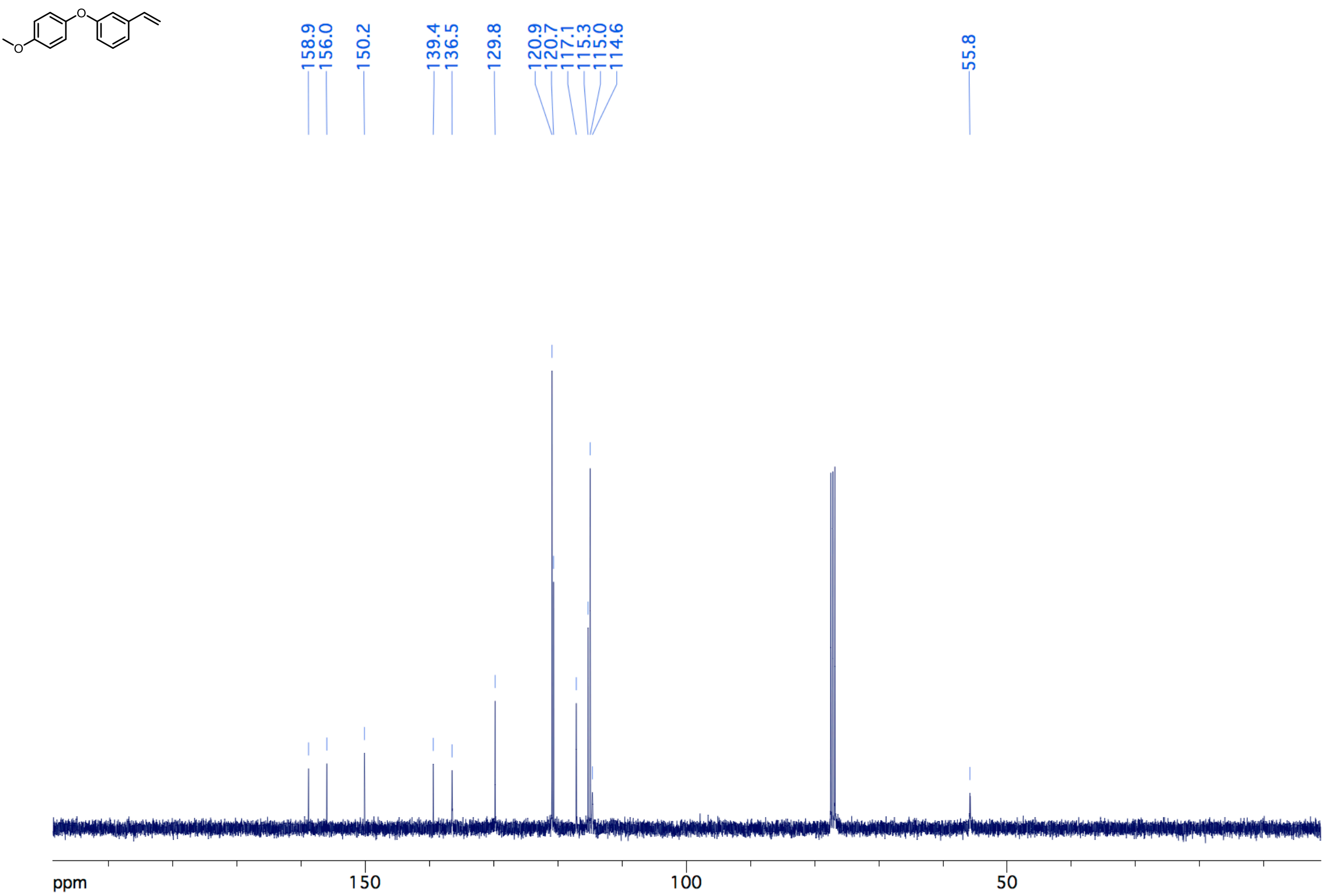

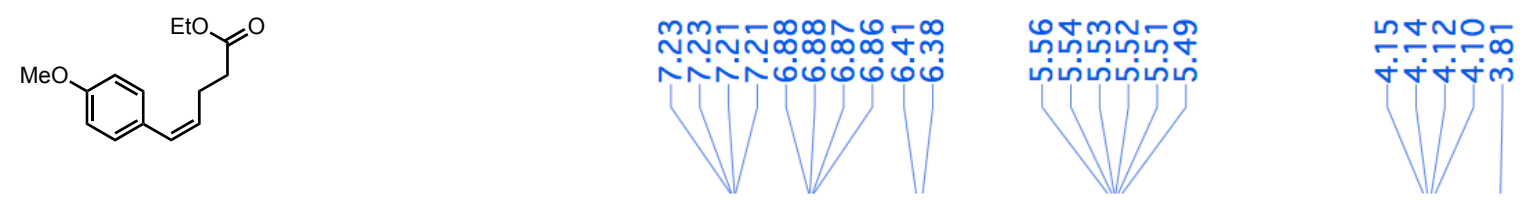

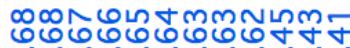

NiNiNiNiNiNiNiNN

กุกฺุกิ

1)

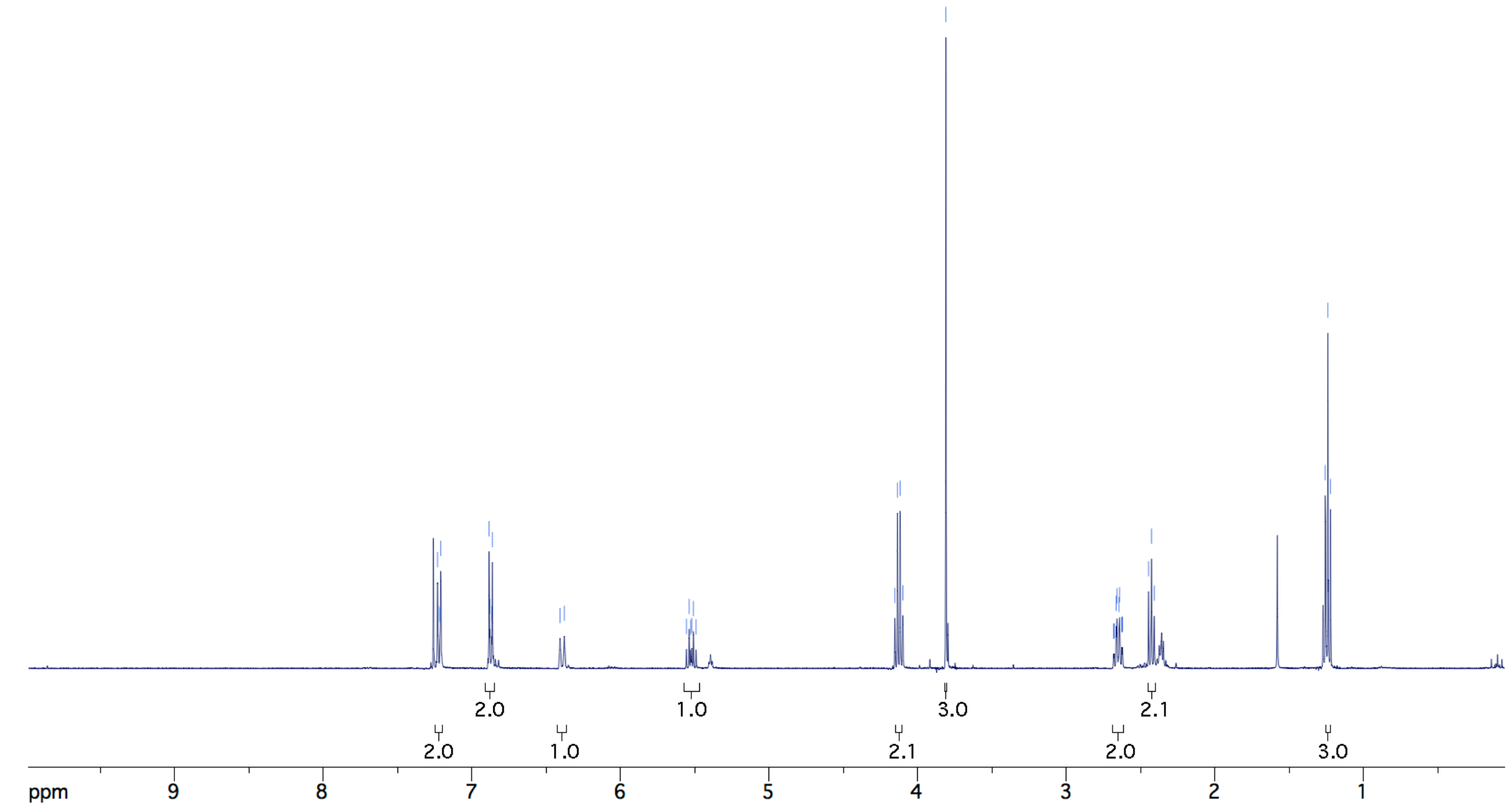




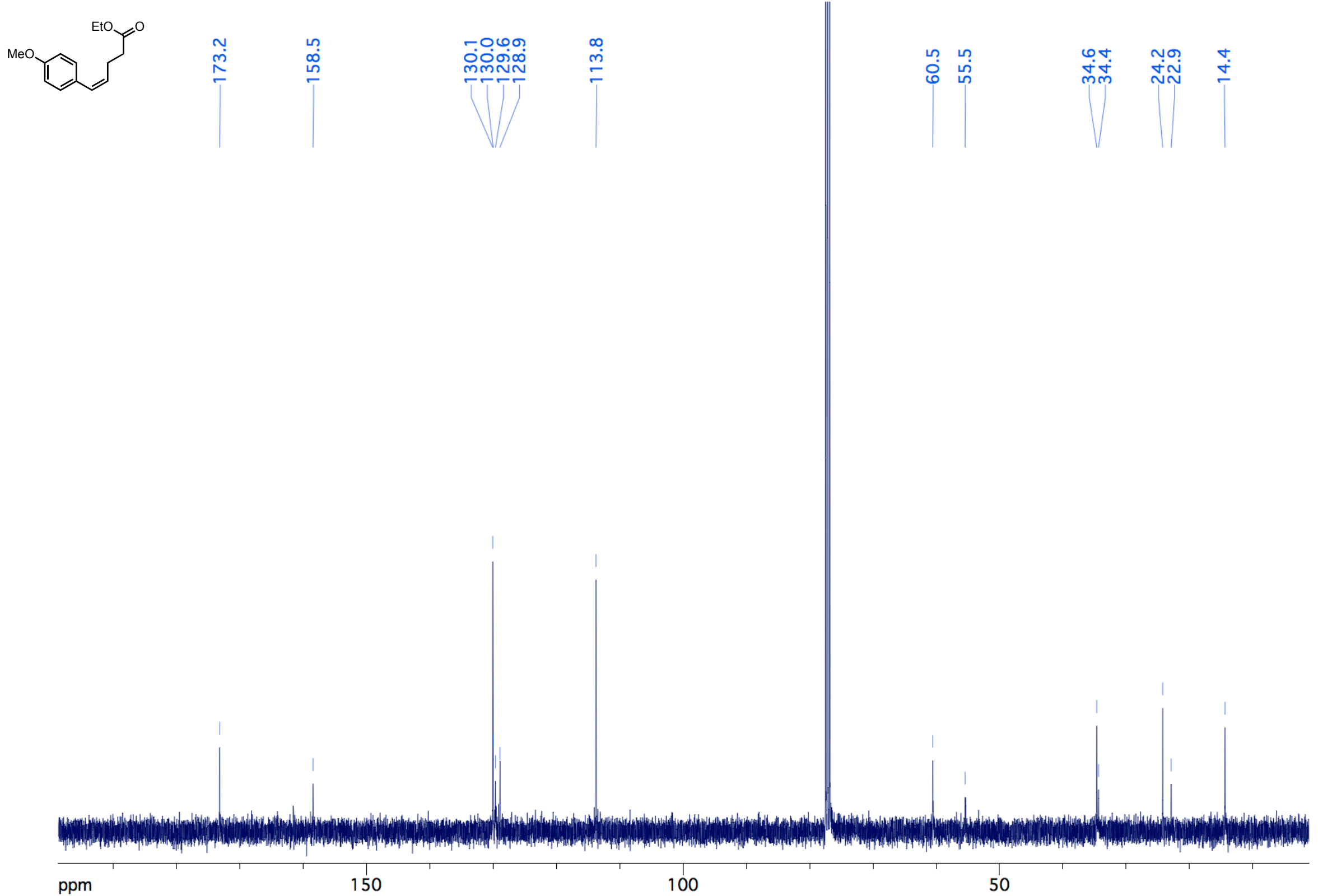




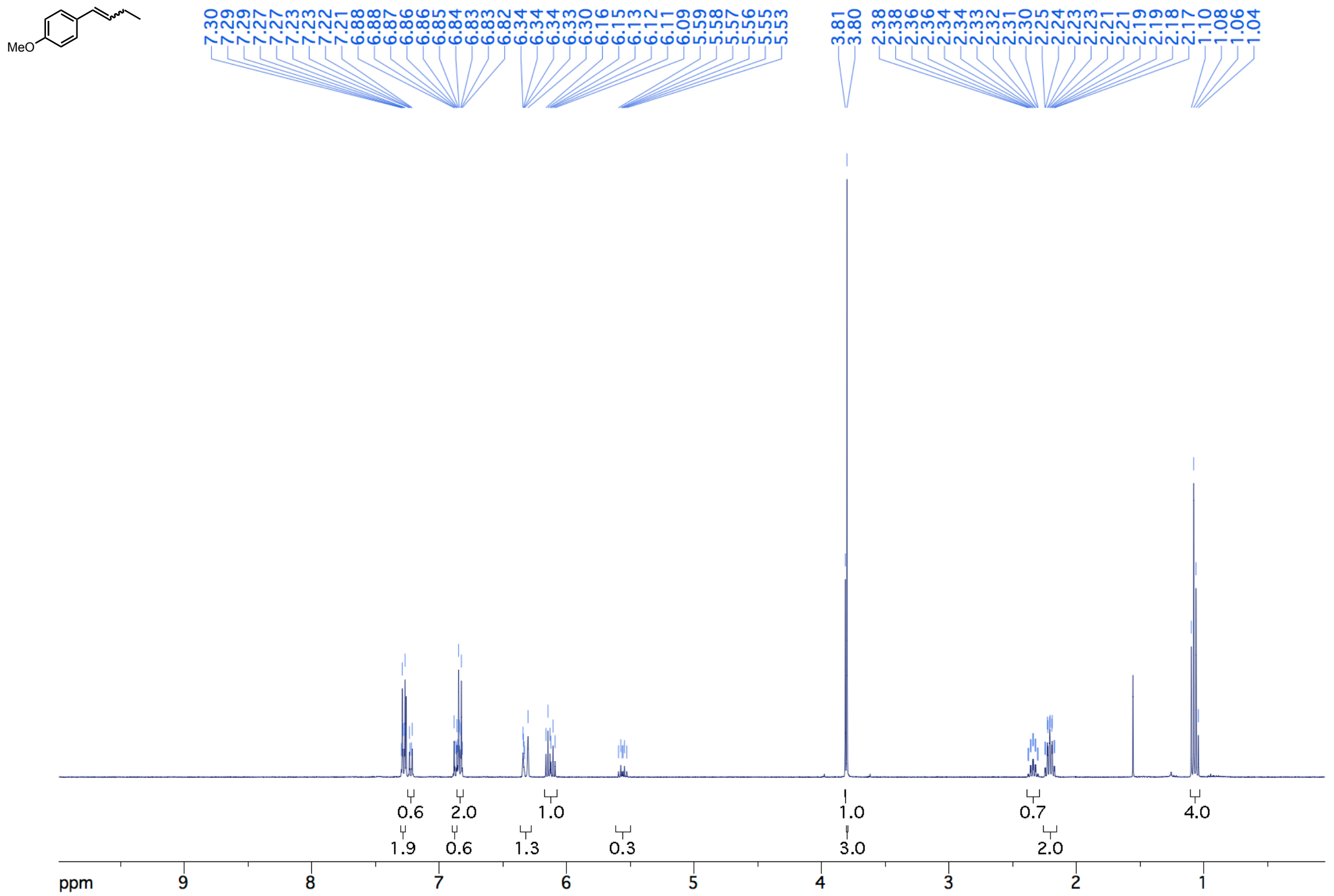




Mmen

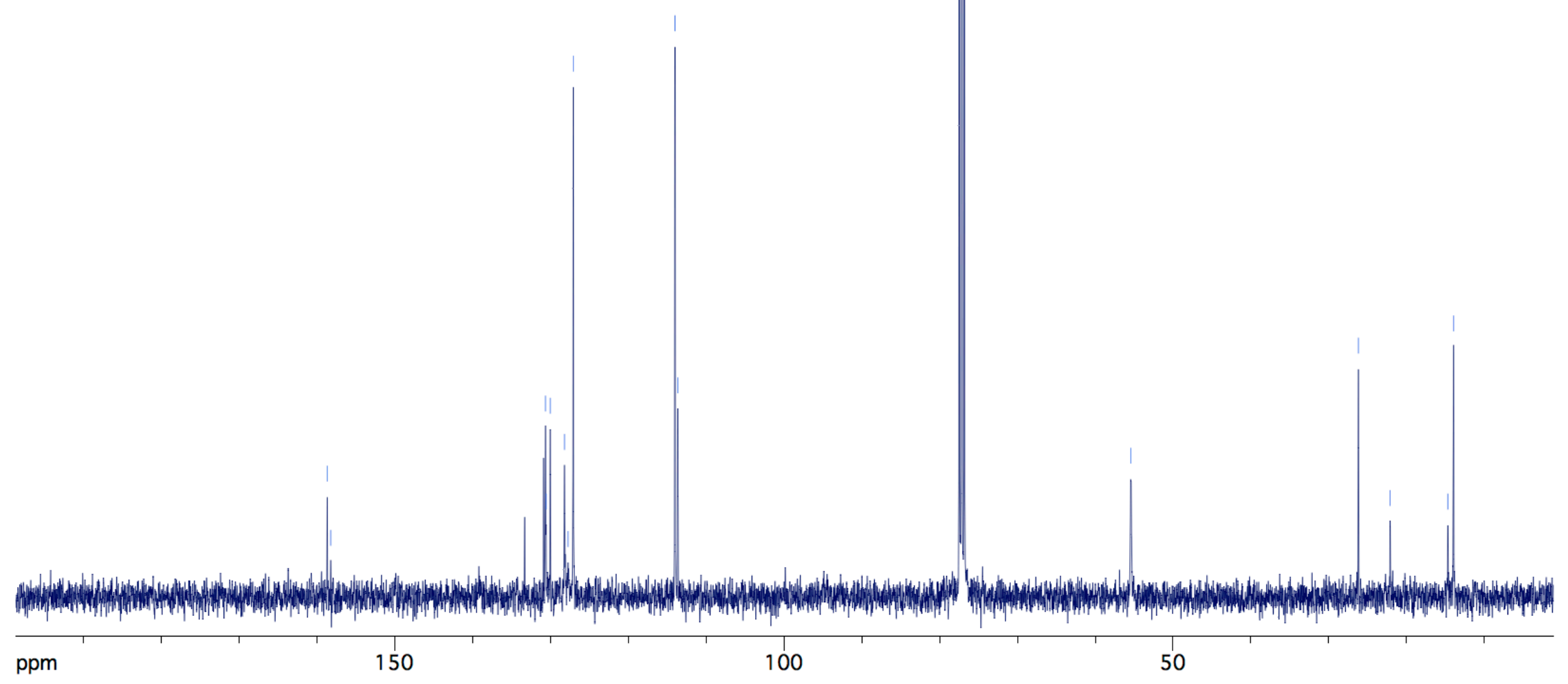


Ethane-1,1-diyldibenzene (2) ${ }^{1} \mathrm{H}$ NMR $\left(\mathrm{CDCl}_{3}, 400 \mathrm{MHz}\right)$

ote

minn

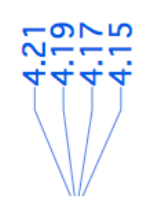

i

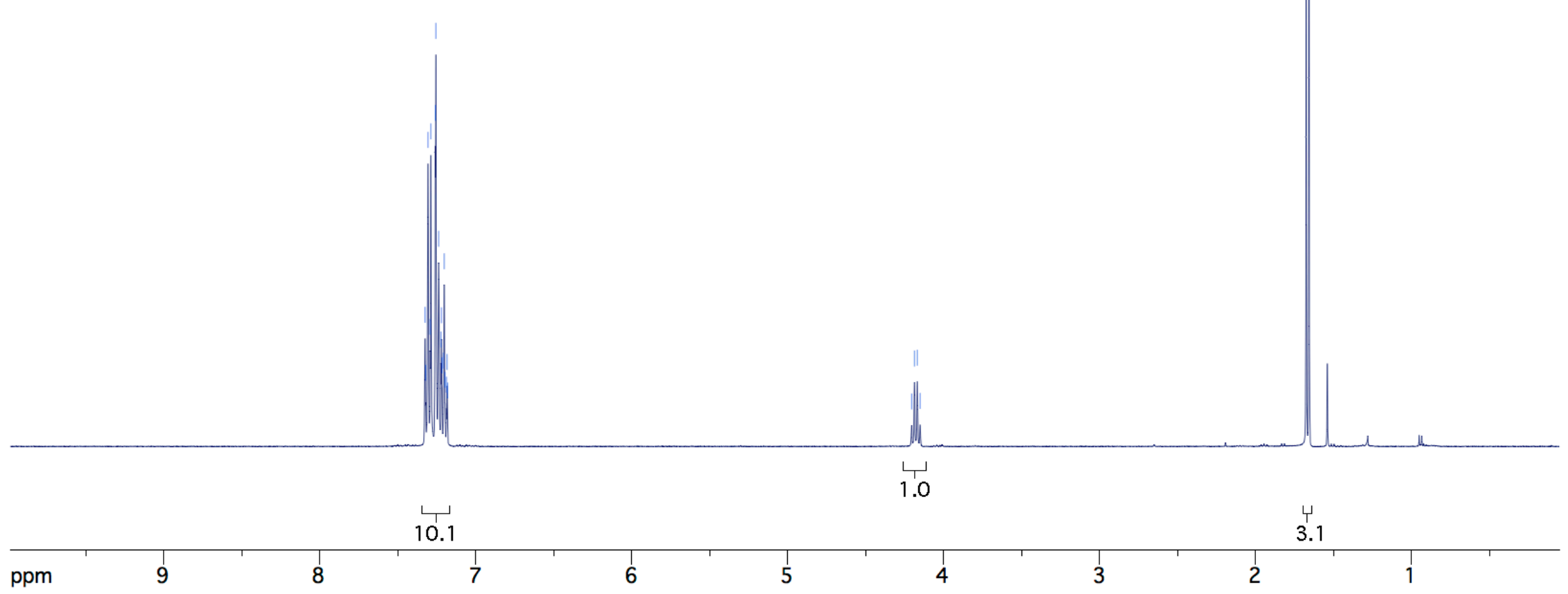

105 
Ethane-1,1-diyldibenzene (2) ${ }^{13} \mathrm{C} \mathrm{NMR}\left(\mathrm{CDCl}_{3}, 100 \mathrm{MHz}\right)$

(1)
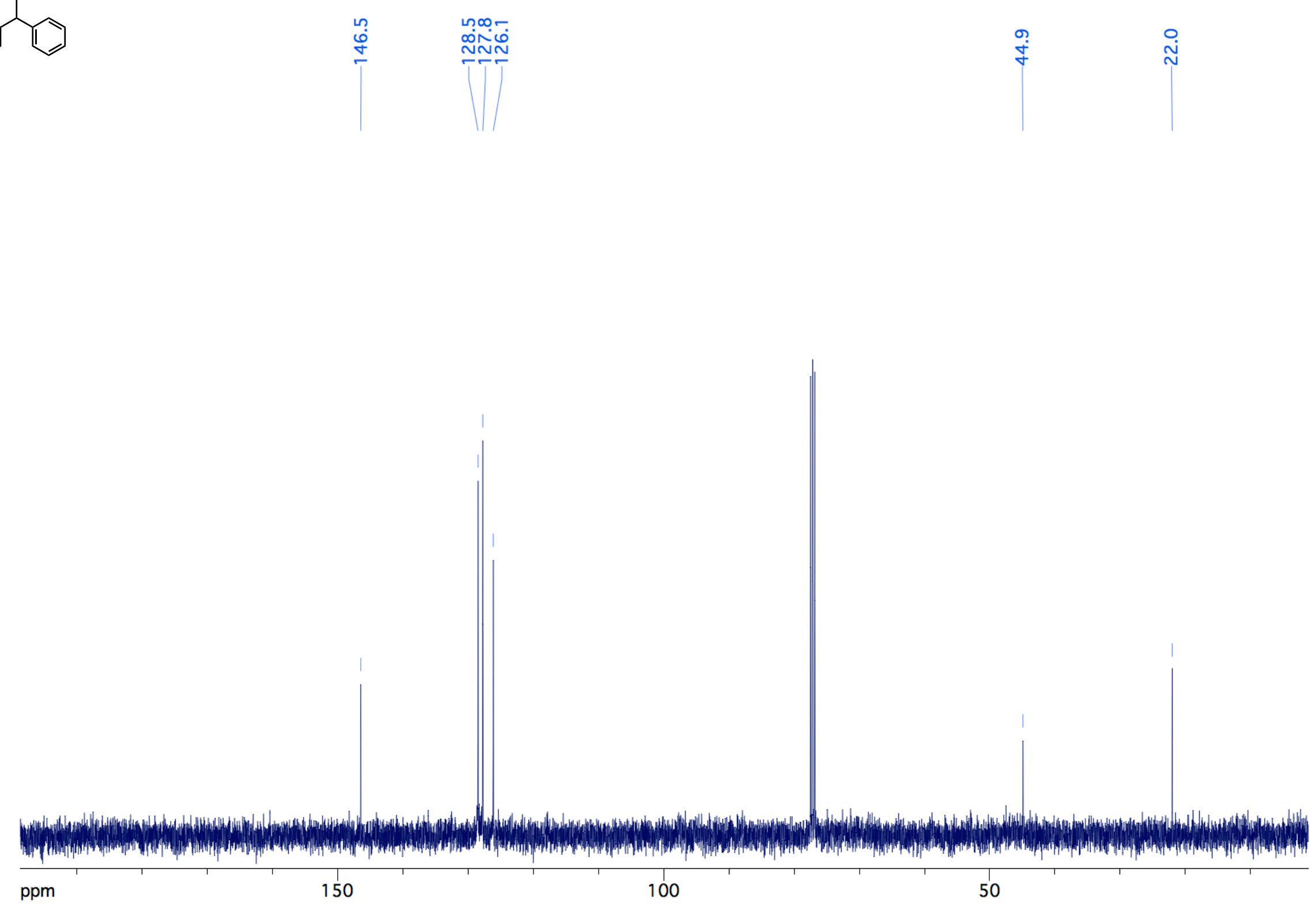

106 
$\mathbf{N}, \mathbf{N}$-diisopropyl-4,4-diphenylbutan-2-amine (3) ${ }^{1} \mathrm{H} \mathrm{NMR}\left(\mathrm{CDCl}_{3}, 400 \mathrm{MHz}\right)$

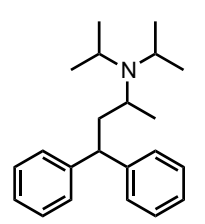

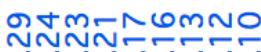

rinivisitio

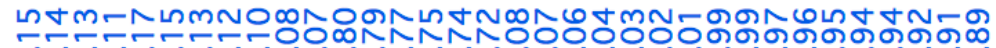

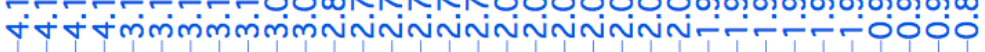
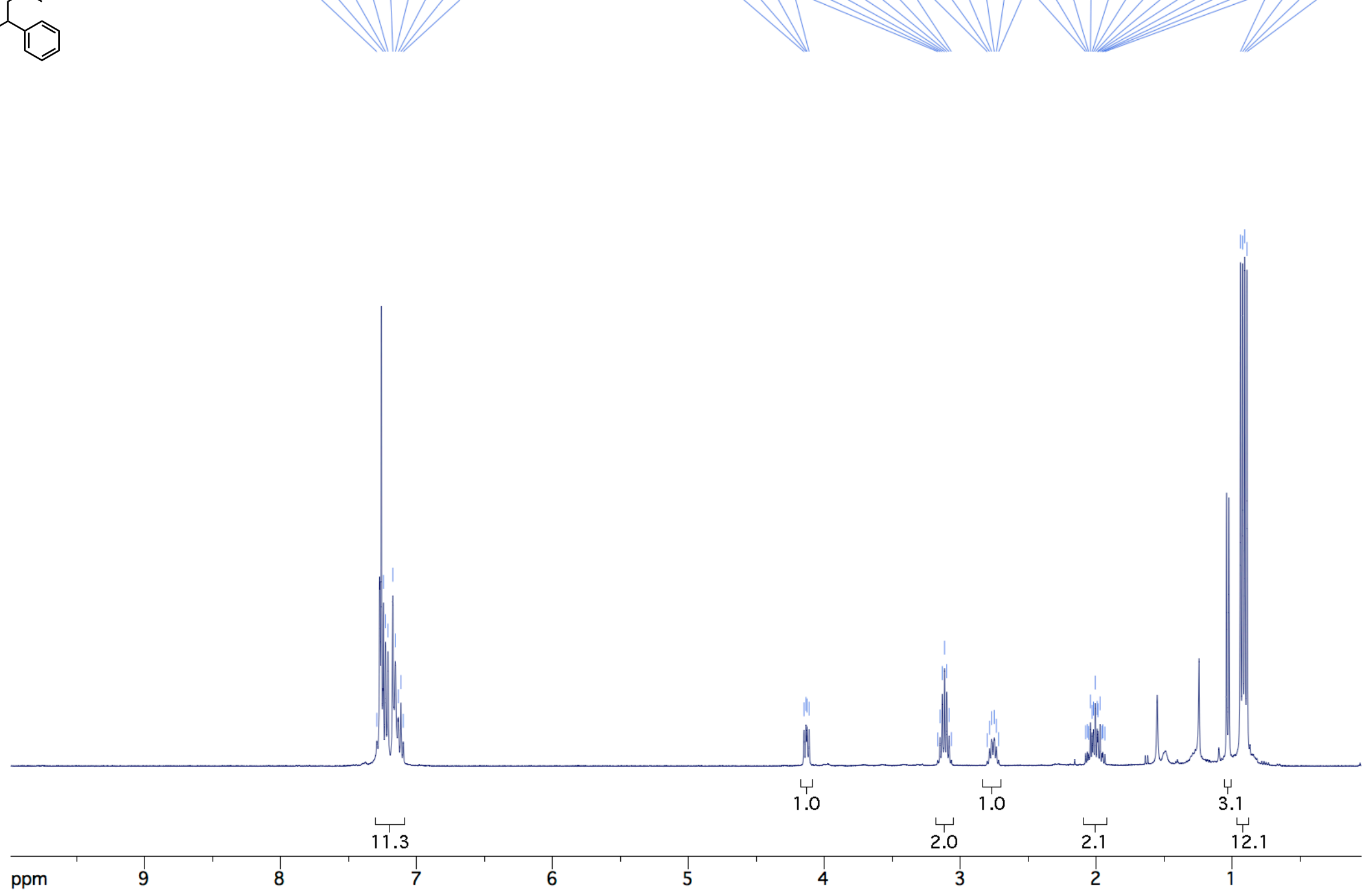
$\boldsymbol{N}, \boldsymbol{N}$-diisopropyl-4,4-diphenylbutan-2-amine (3) ${ }^{13} \mathrm{C} \mathrm{NMR}\left(\mathrm{CDCl}_{3}, 100 \mathrm{MHz}\right)$
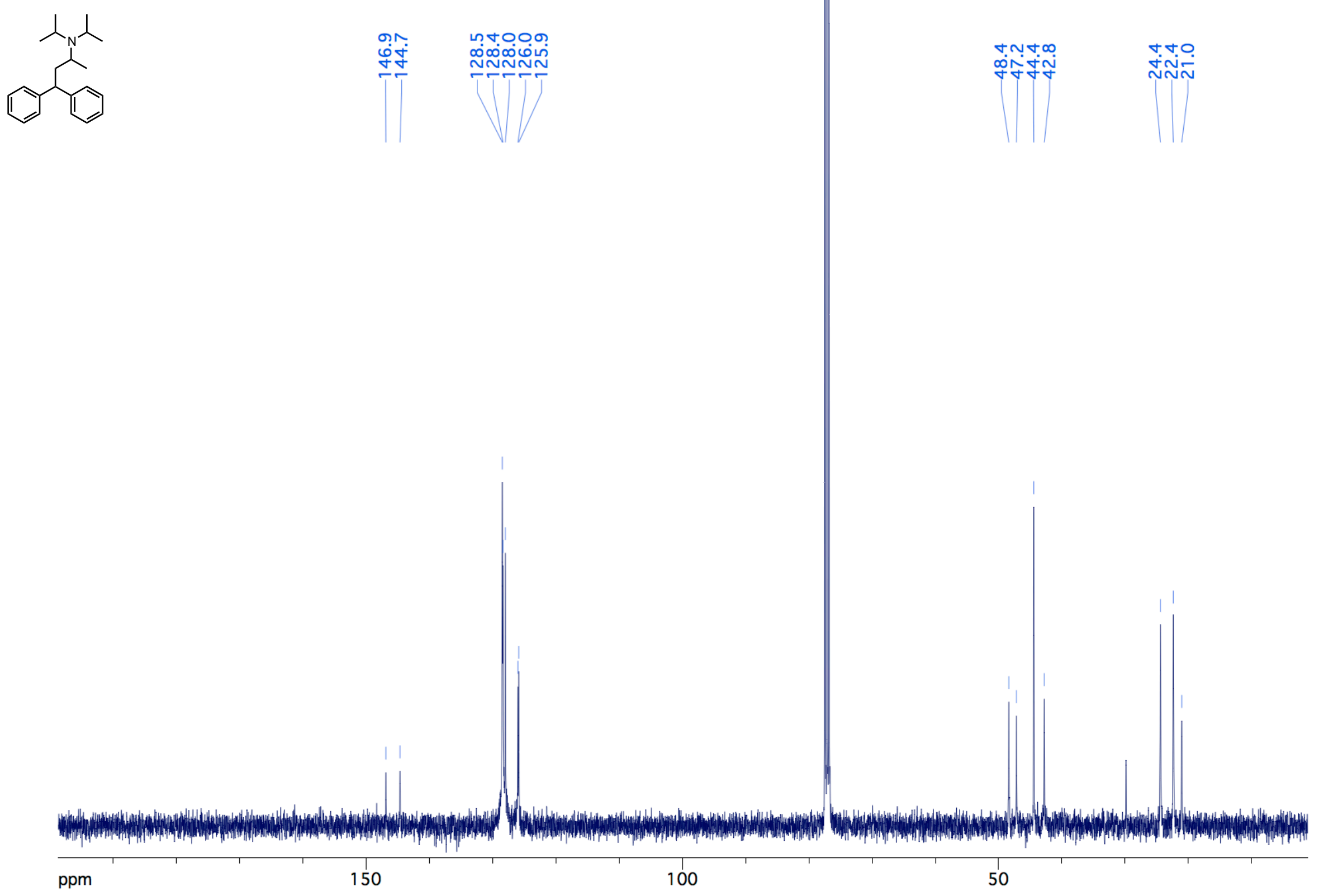
1-Fluoro-4-(1-phenylethyl)benzene (4) ${ }^{1} \mathrm{H} \mathrm{NMR}\left(\mathrm{CDCl}_{3}, 400 \mathrm{MHz}\right)$

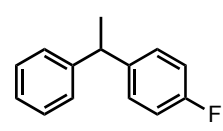

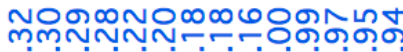

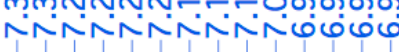

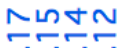

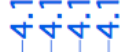

โัต़้

i

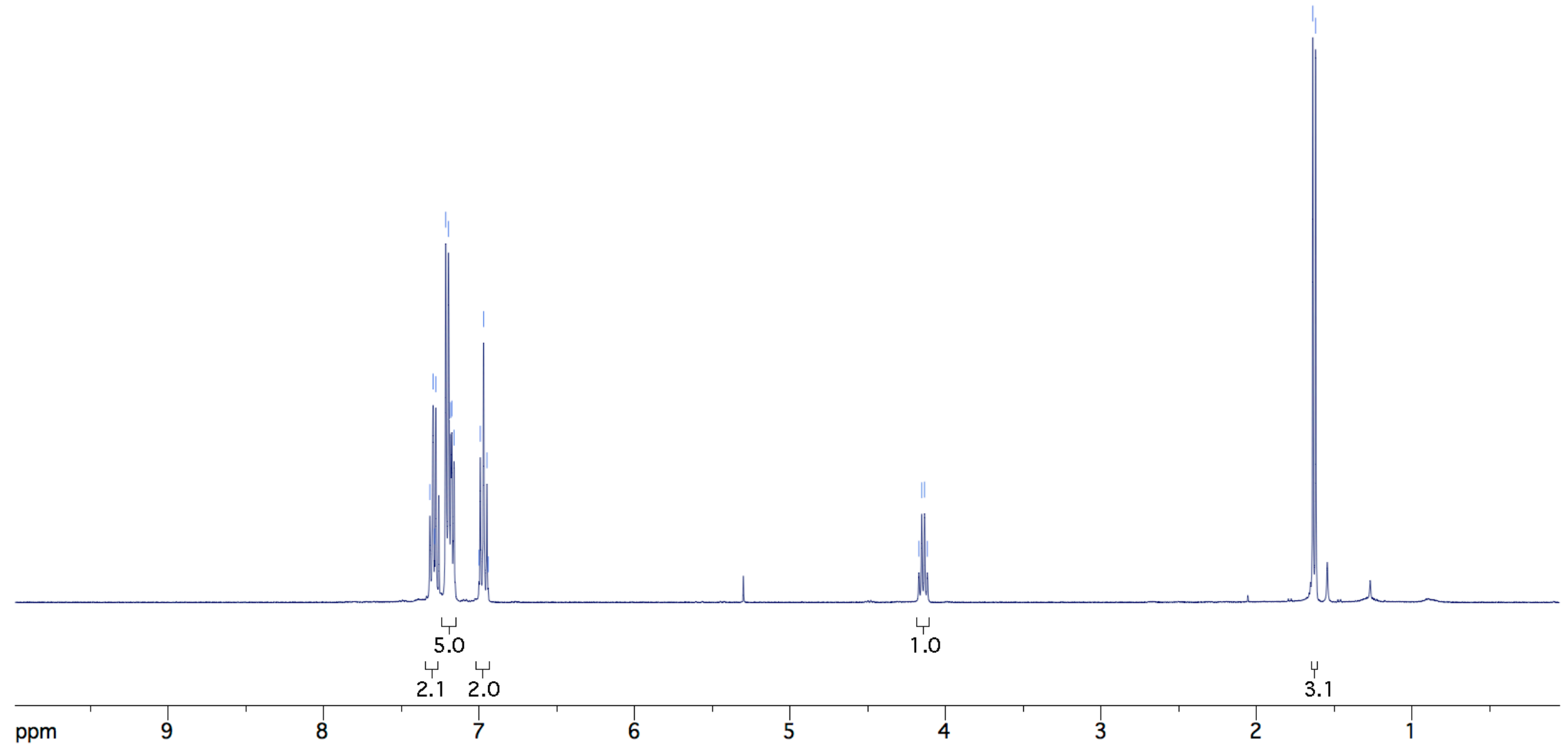


1-Fluoro-4-(1-phenylethyl)benzene (4) ${ }^{13} \mathrm{C} \mathrm{NMR}\left(\mathrm{CDCl}_{3}, 100 \mathrm{MHz}\right)$

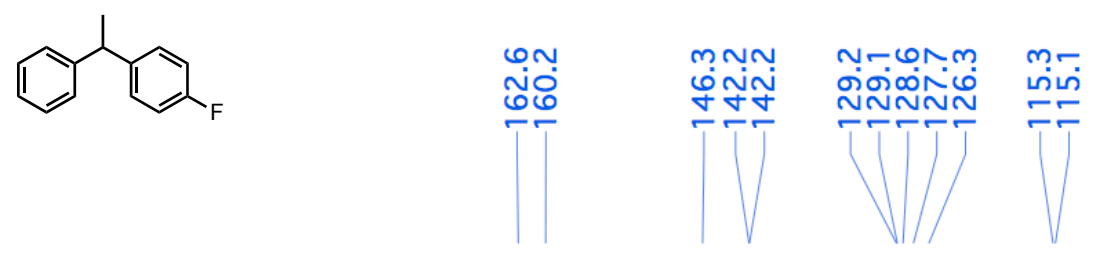

$\underset{\mathfrak{N}}{\mathfrak{N}}$

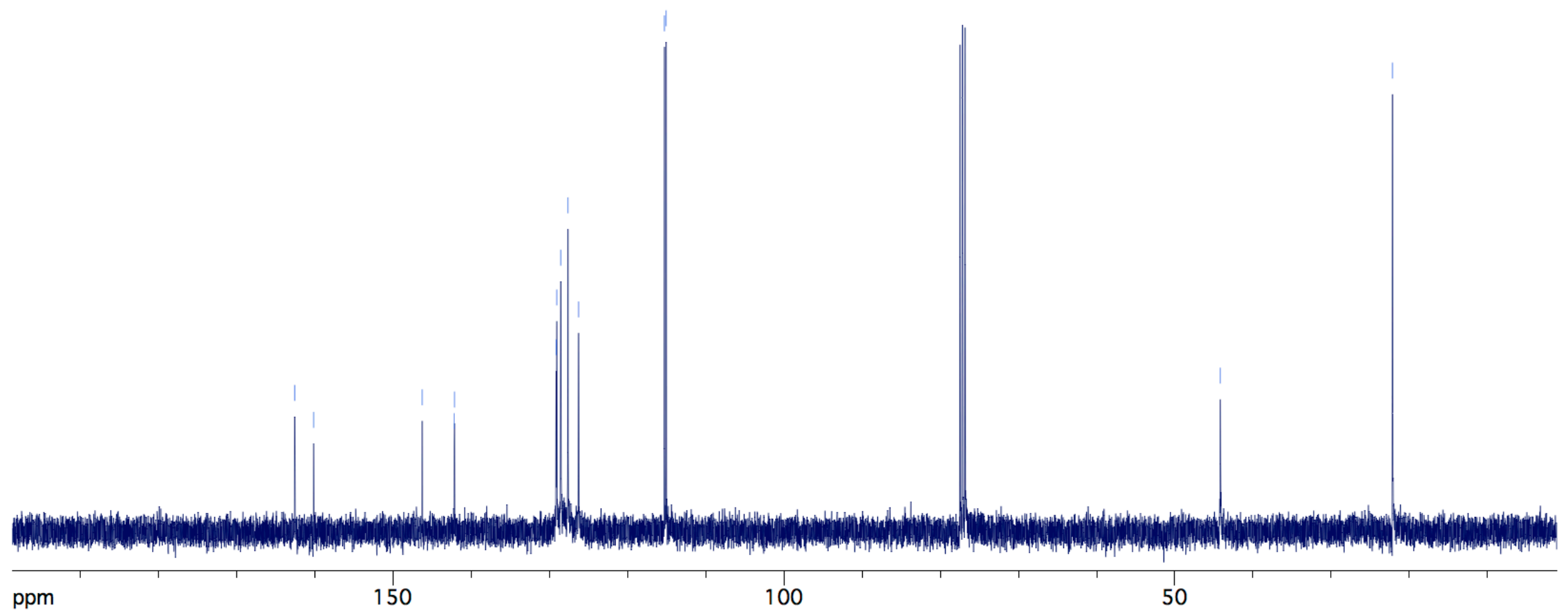


1-Fluoro-4-(1-phenylethyl)benzene (4) ${ }^{19} \mathrm{~F}-\mathrm{NMR}\left(\mathrm{CDCl}_{3}, 376 \mathrm{MHz}\right)$
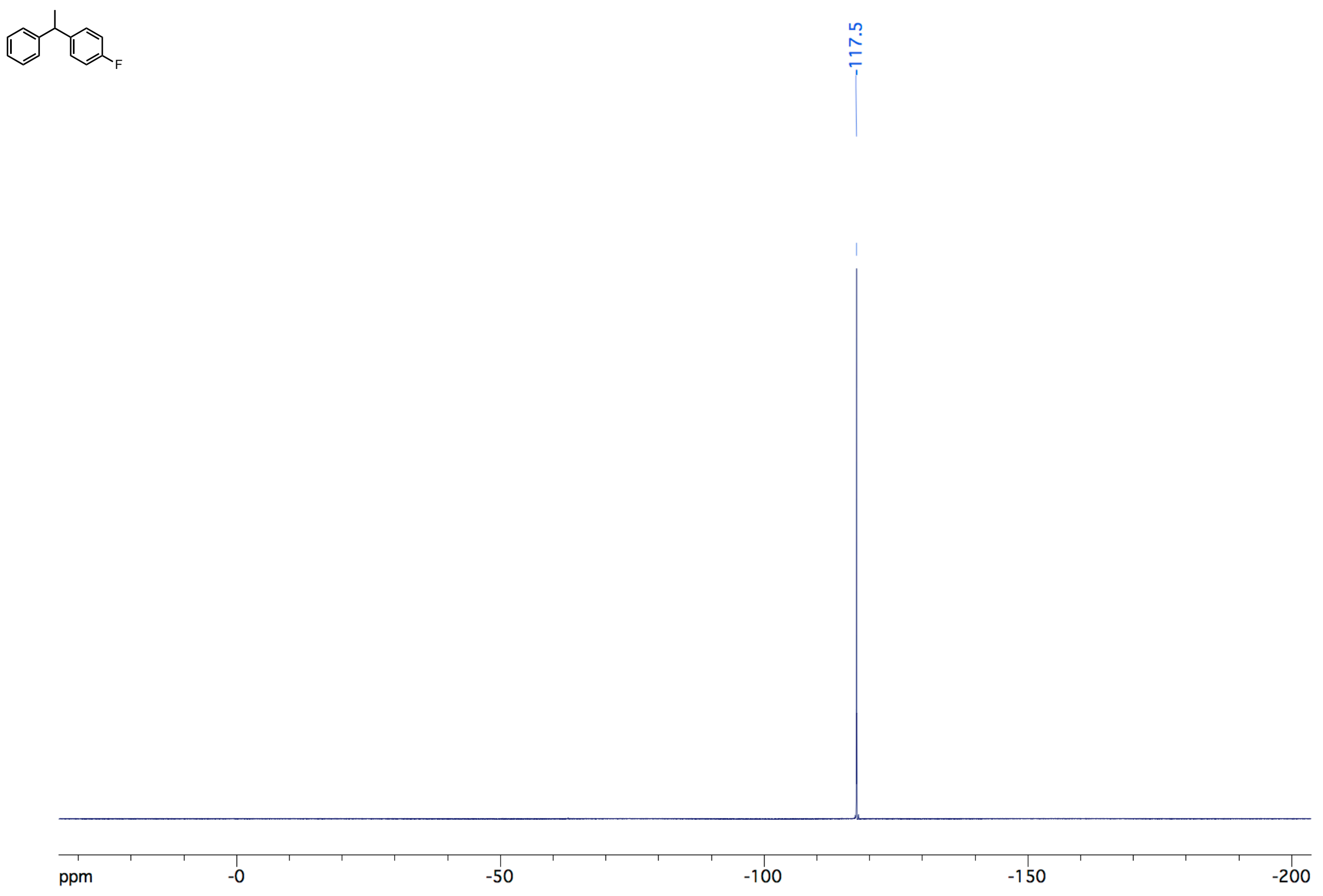


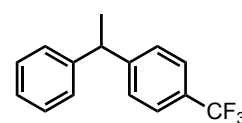

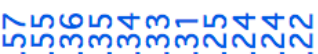

$\mathrm{CF}_{3}$

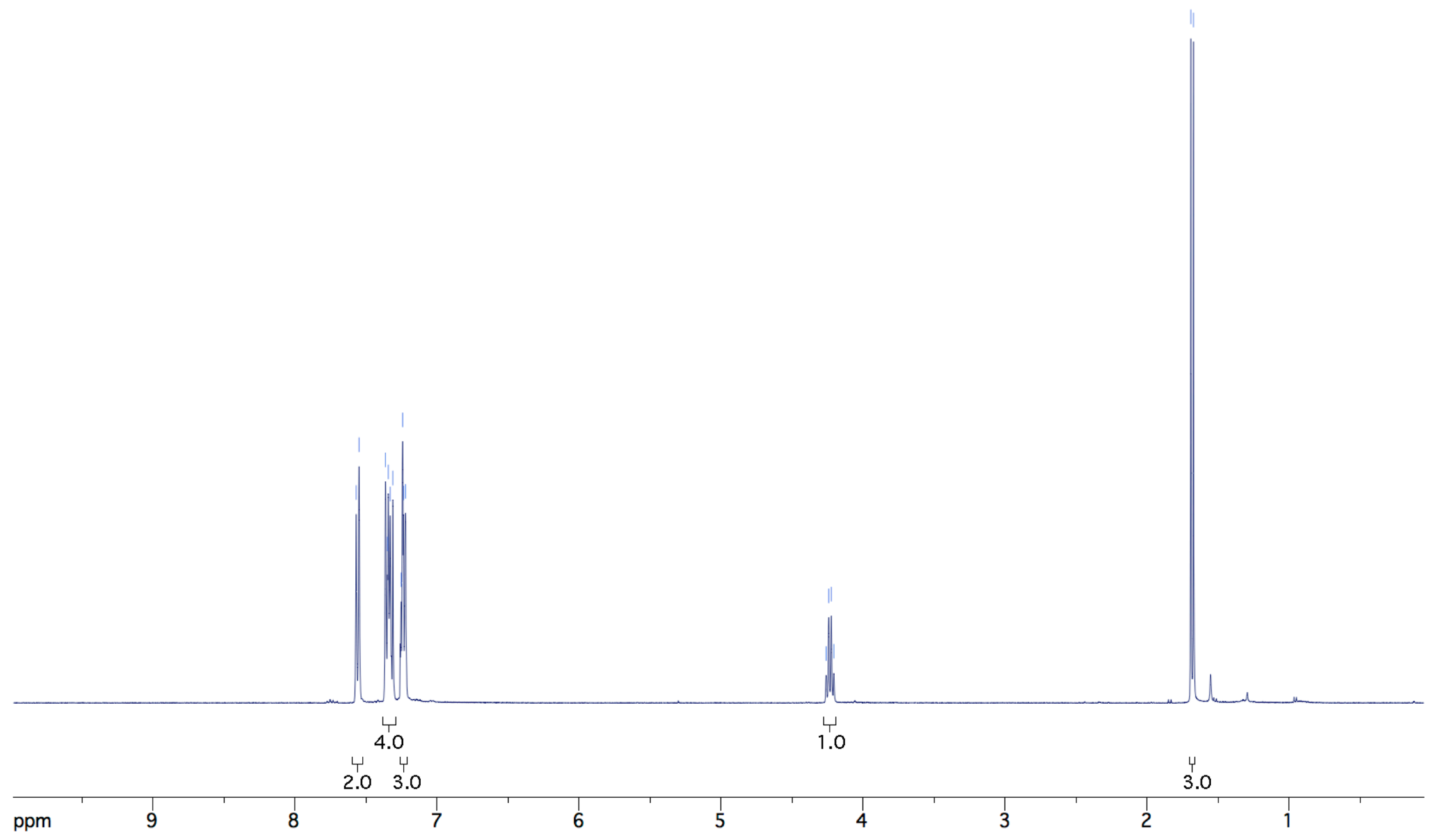




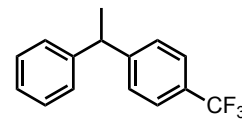

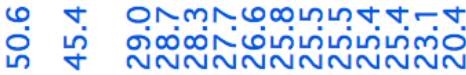

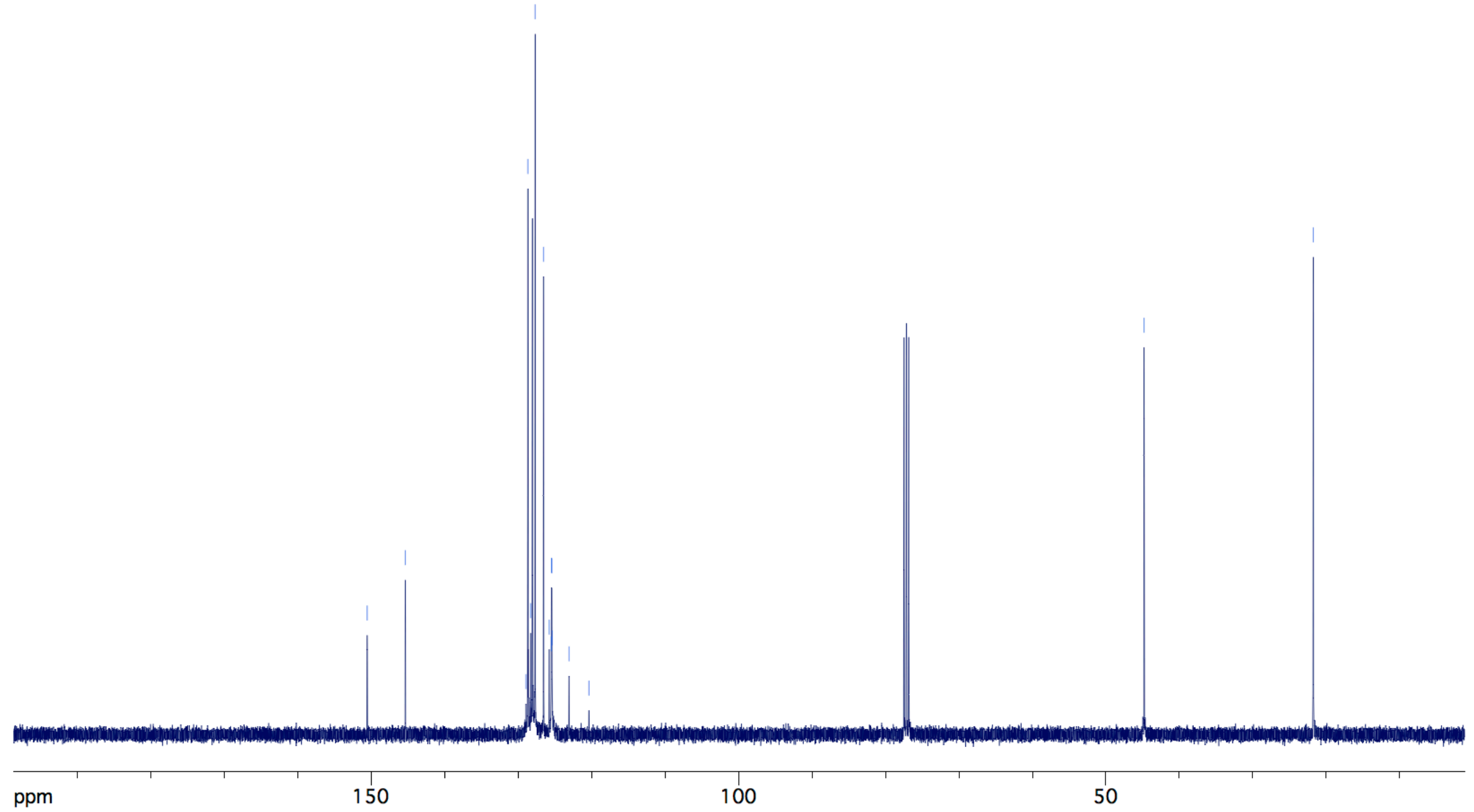



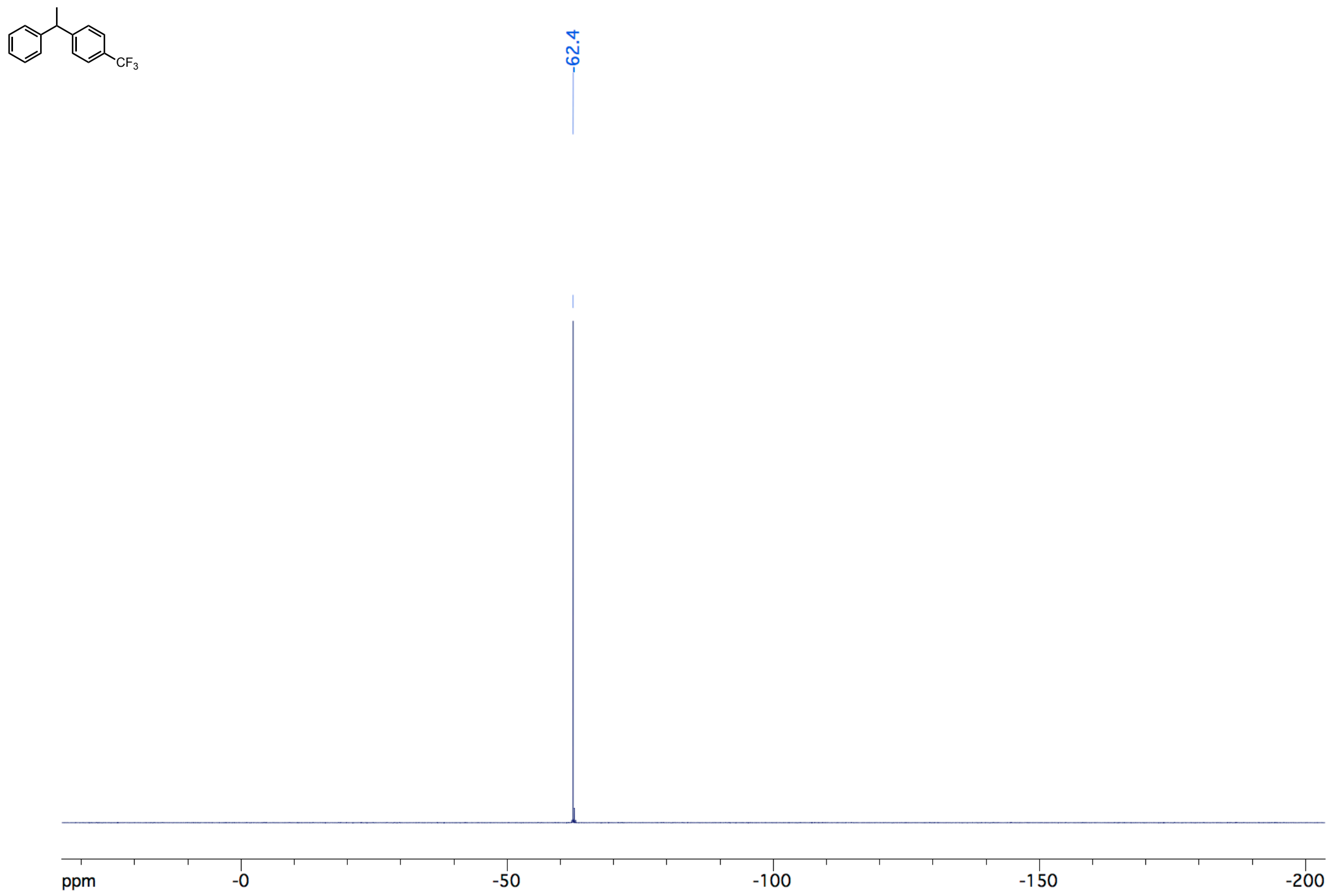
1-Chloro-3-(1-phenylethyl)benzene (6) ${ }^{1} \mathrm{H}$ NMR $\left(\mathrm{CDCl}_{3}, 400 \mathrm{MHz}\right)$

(1)
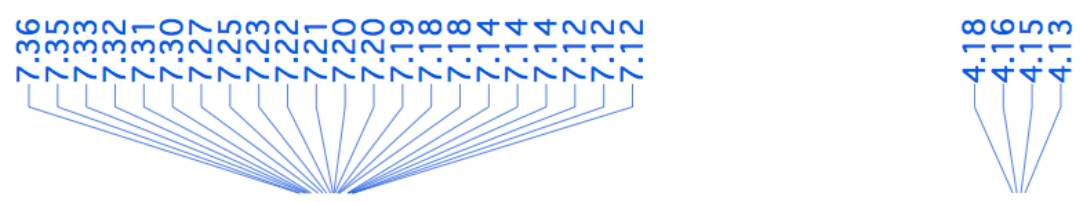

i

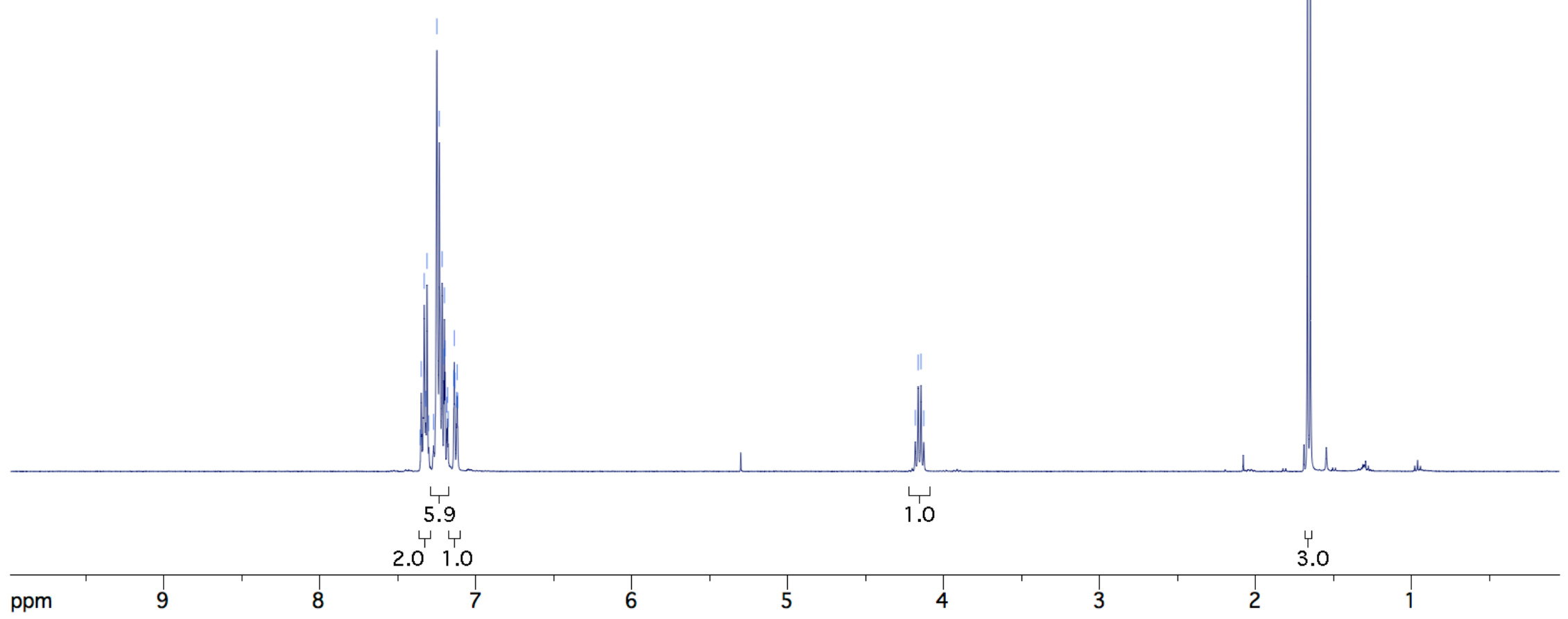

115 
1-Chloro-3-(1-phenylethyl)benzene (6) ${ }^{13} \mathrm{C} \mathrm{NMR}\left(\mathrm{CDCl}_{3}, 100 \mathrm{MHz}\right)$
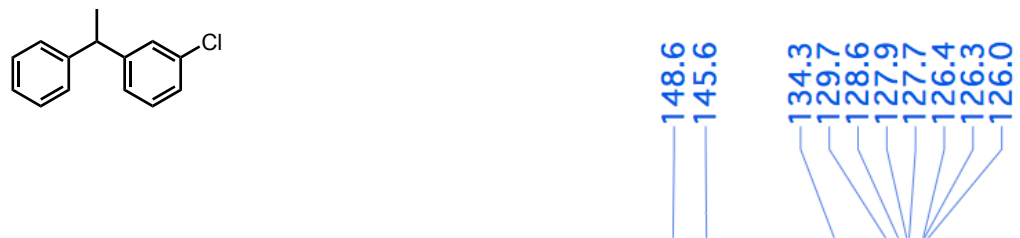

$\stackrel{+}{\stackrel{n}{d}} \quad \stackrel{\infty}{\frac{\pi}{2}}$

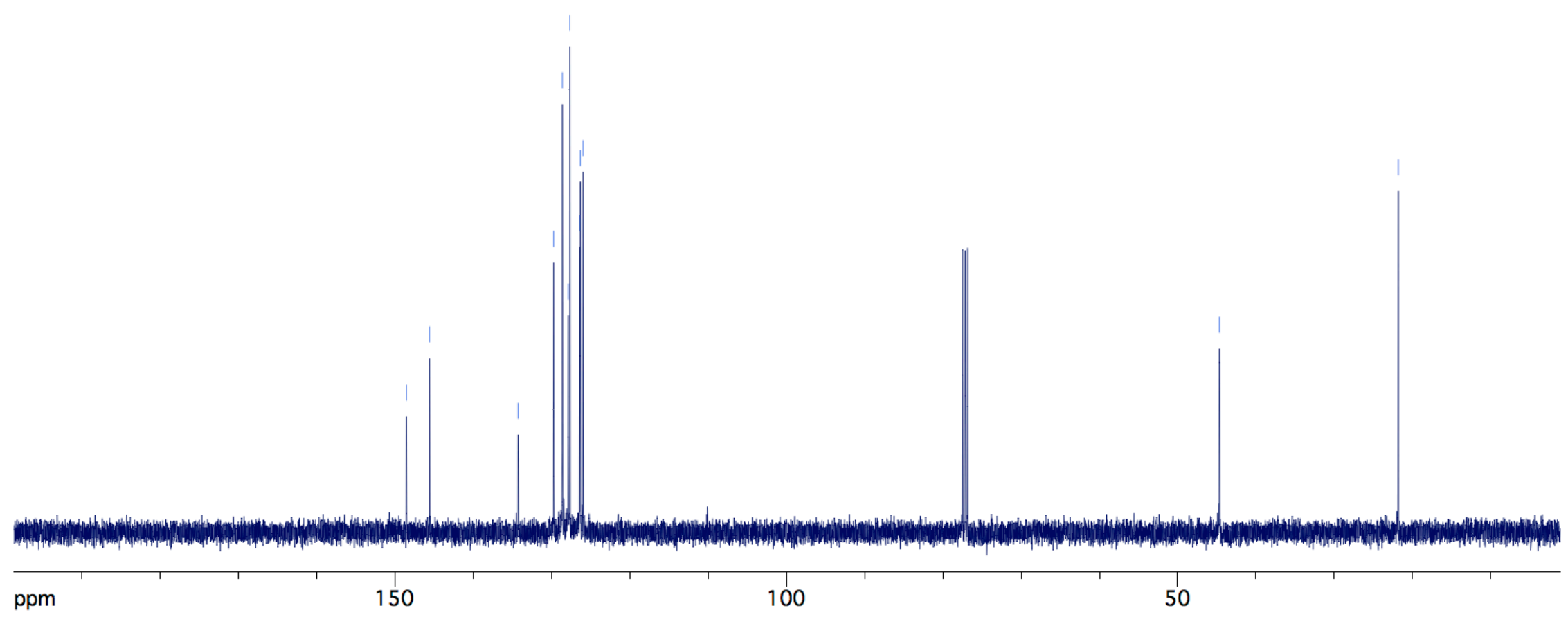


1-Chloro-4-(1-phenylethyl)benzene (7) ${ }^{1} \mathrm{H}$ NMR $\left(\mathrm{CDCl}_{3}, 600 \mathrm{MHz}\right)$

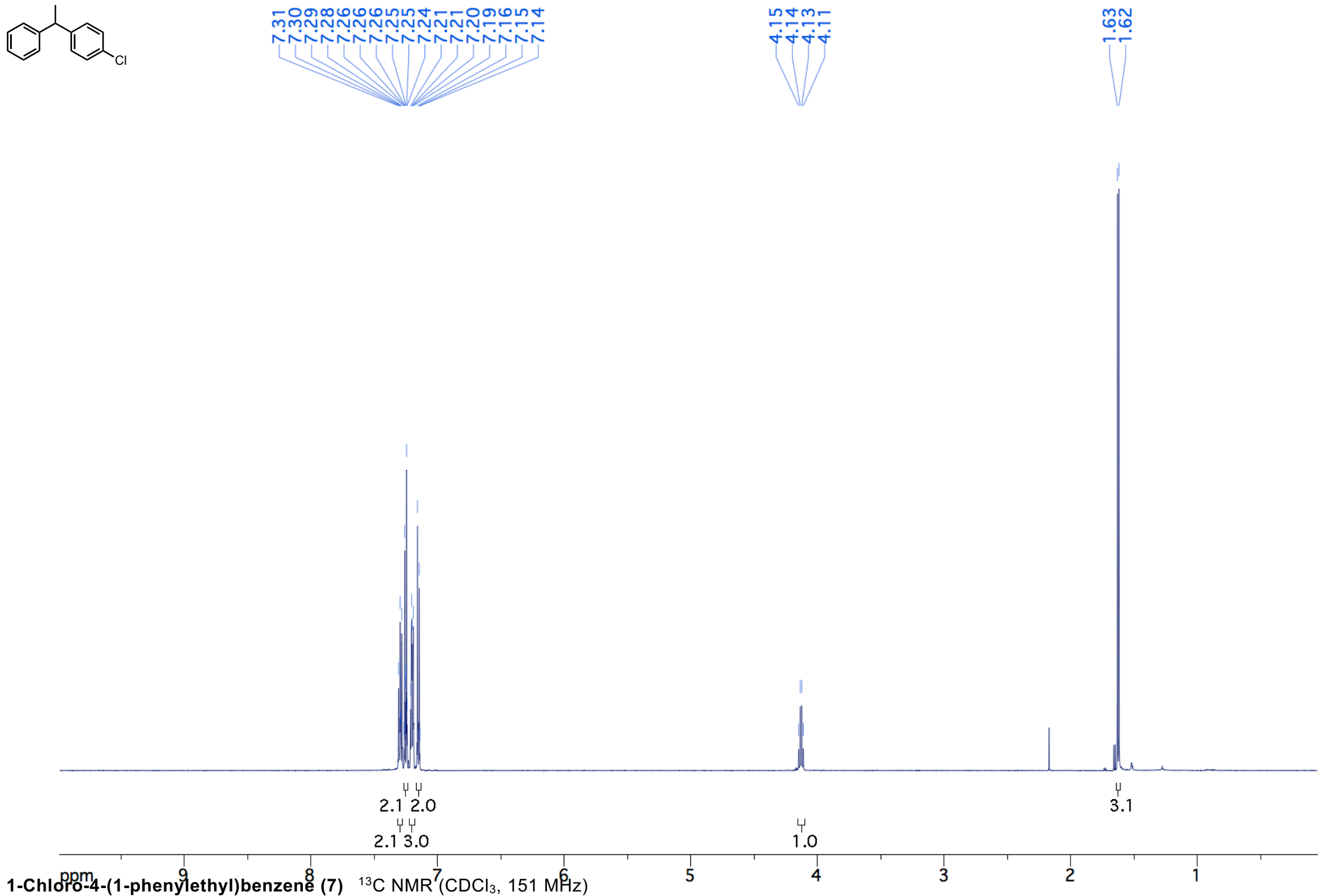



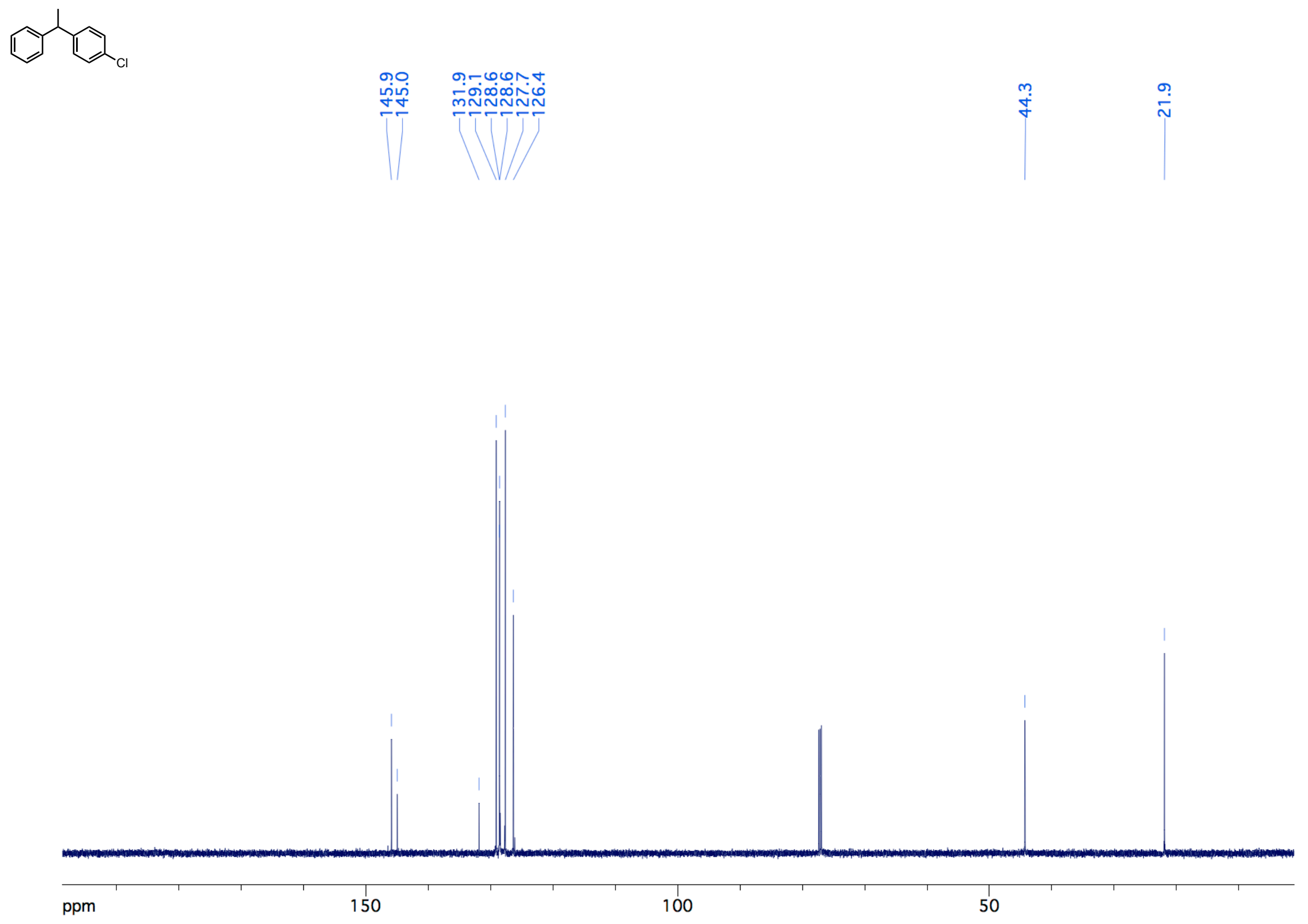


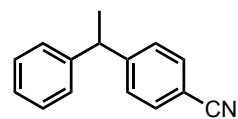

แัM-

NiNiNiNiN

กิก-

ช̛チ̛์

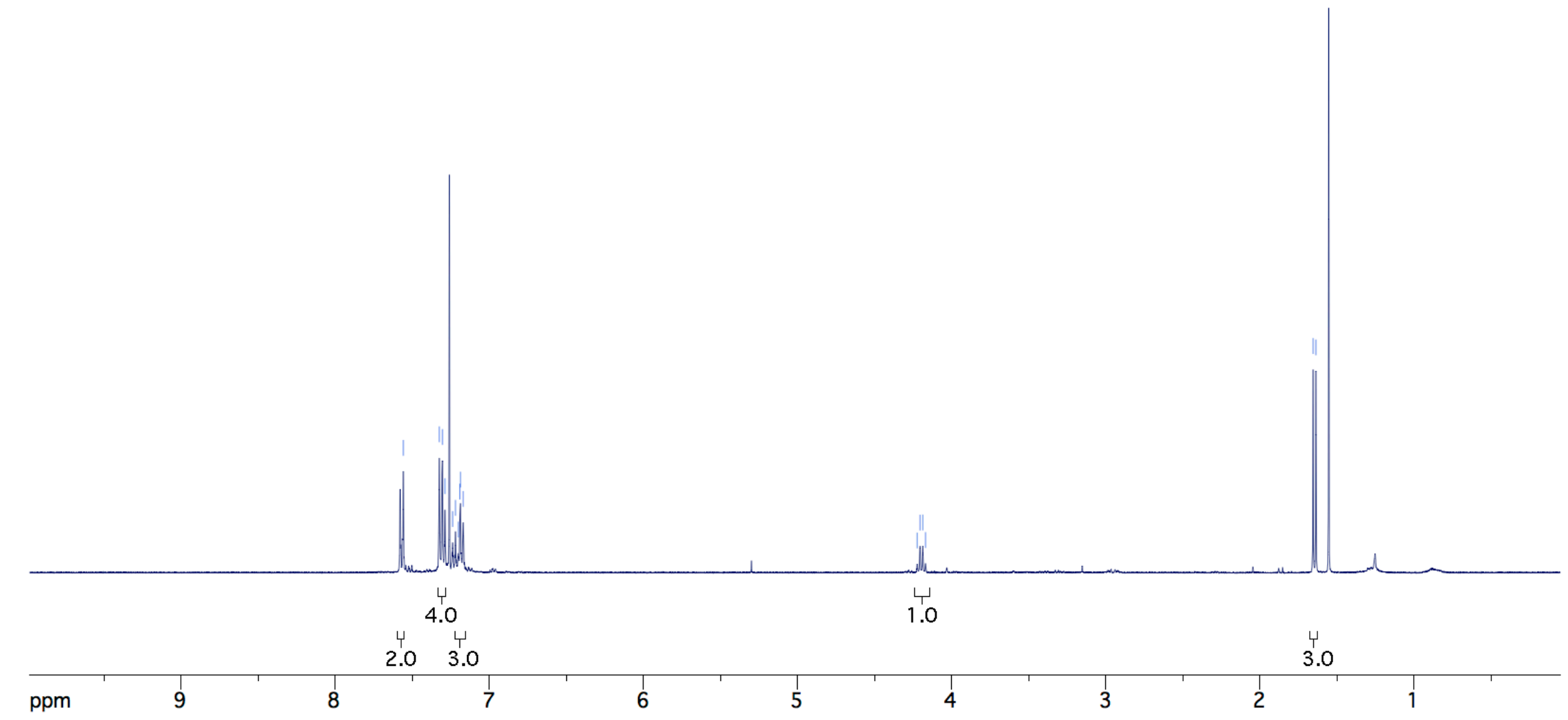



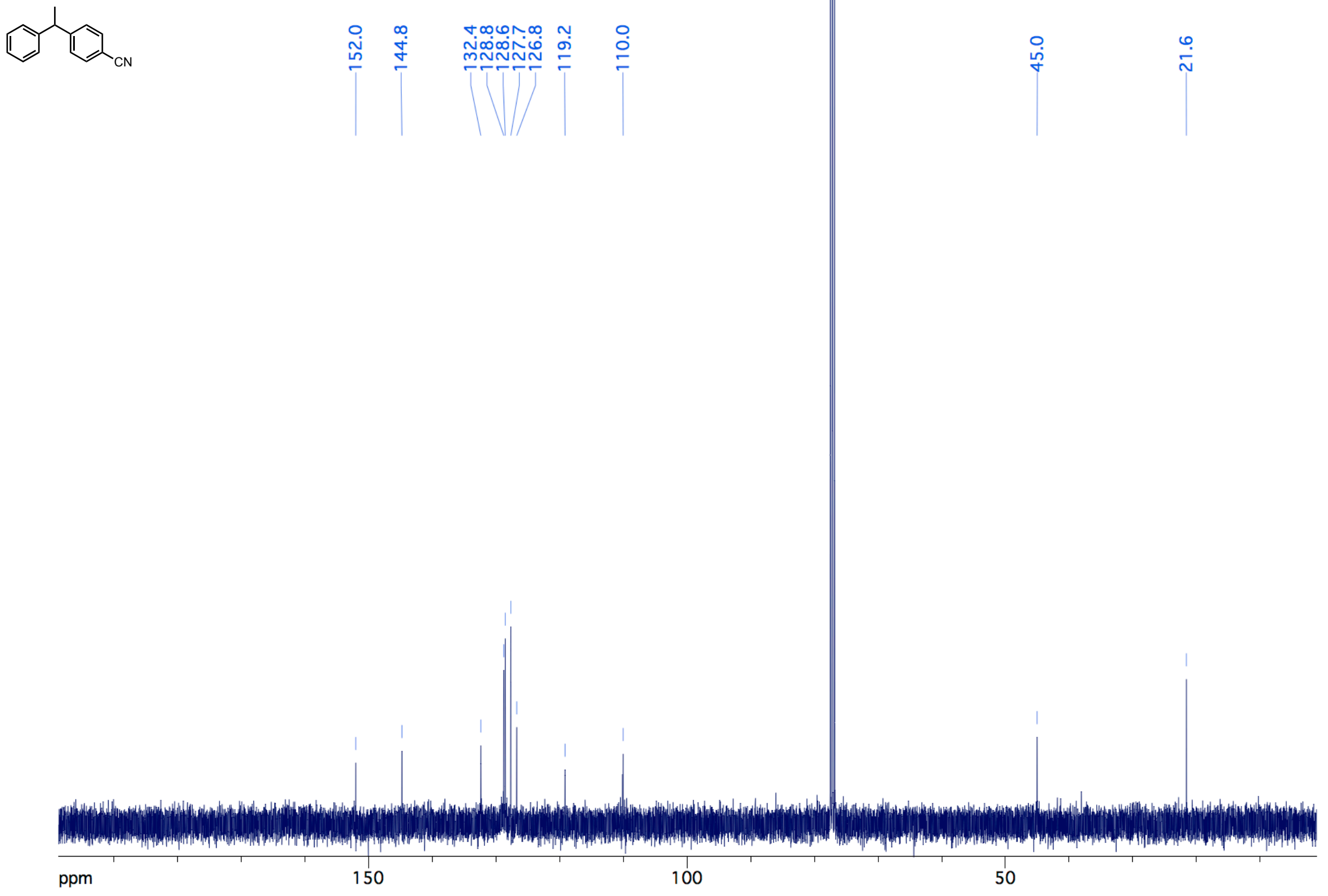
Methyl 4-(1-phenylethyl)benzoate (9) ${ }^{1} \mathrm{H}$ NMR $\left(\mathrm{CDCl}_{3}, 600 \mathrm{MHz}\right)$
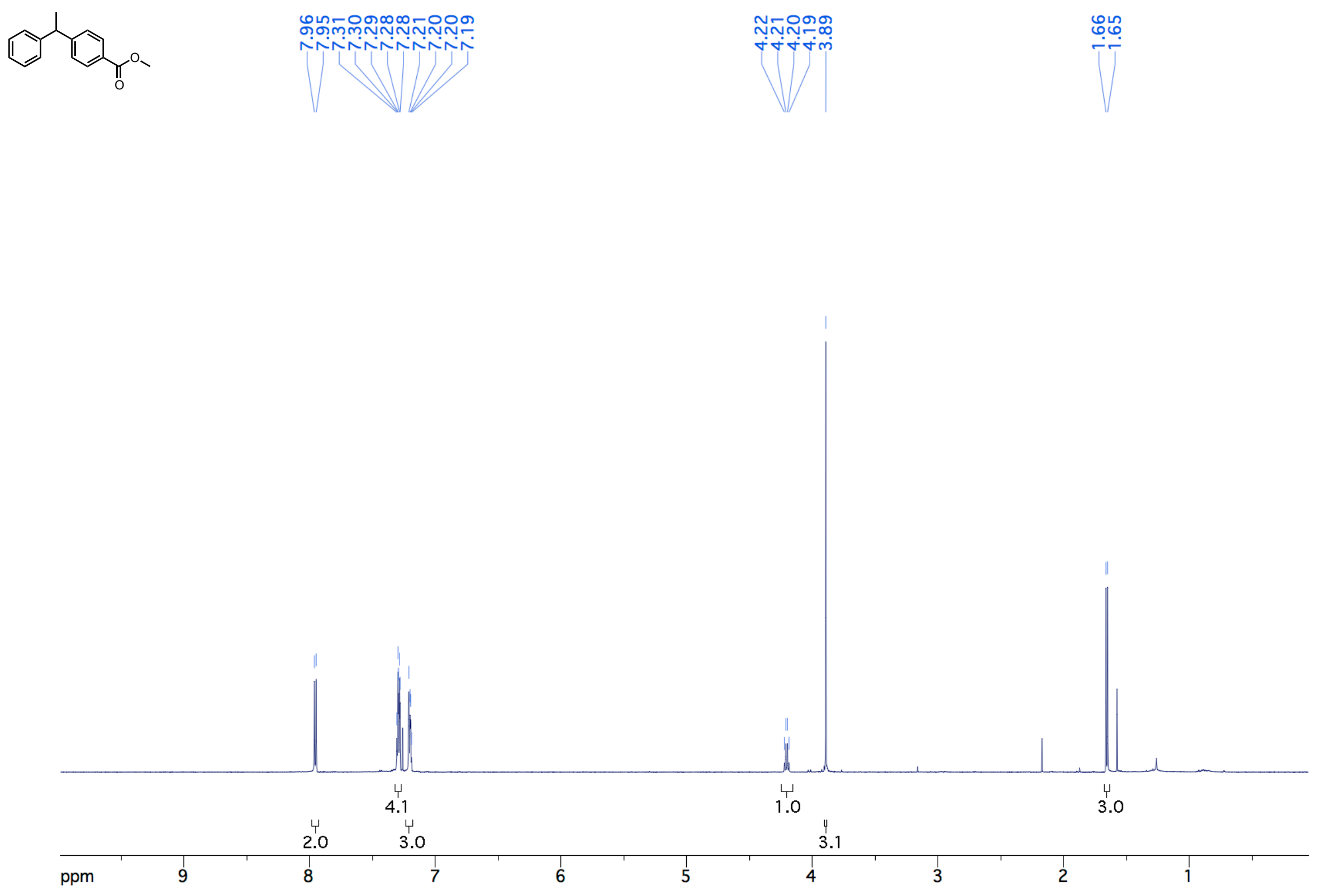
Methyl 4-(1-phenylethyl)benzoate (9) ${ }^{13} \mathrm{C} \mathrm{NMR}\left(\mathrm{CDCl}_{3}, 151 \mathrm{MHz}\right)$

11.

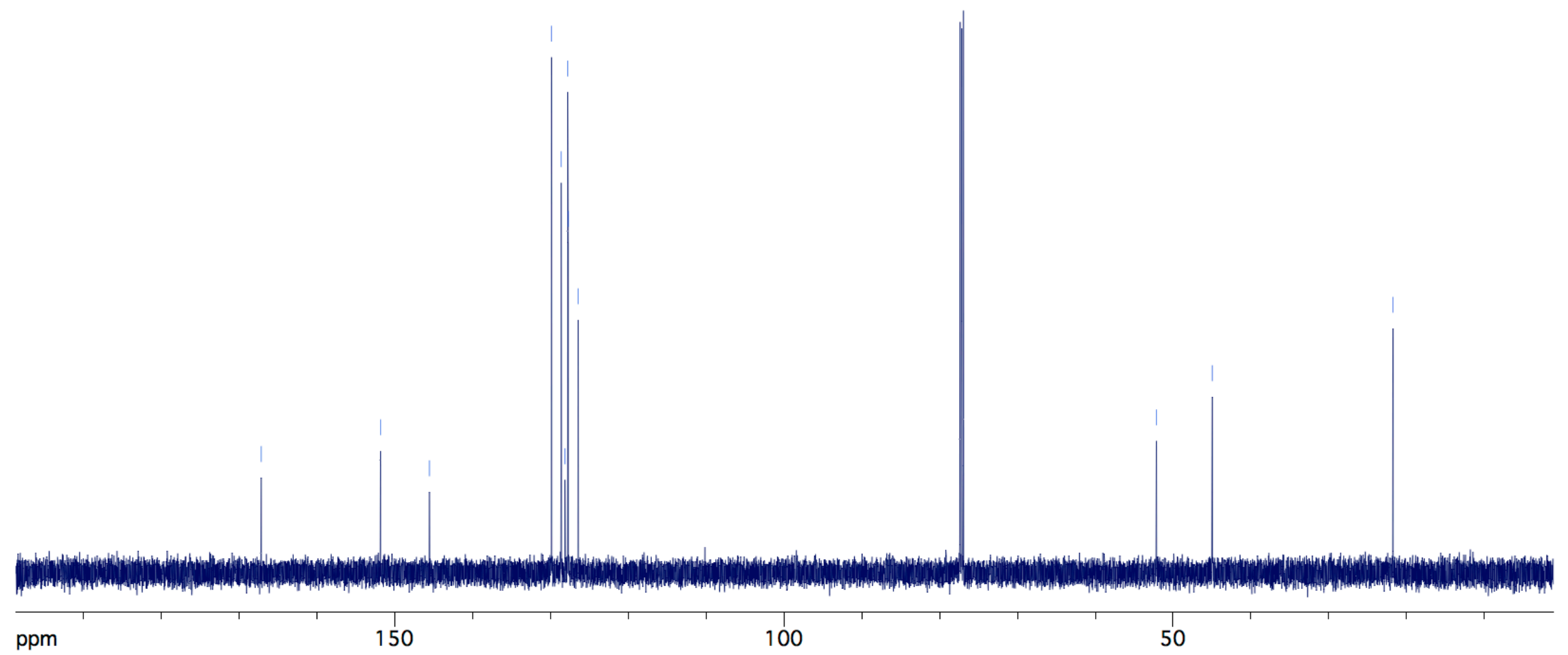


${ }^{1} \mathrm{H} \mathrm{NMR}\left(\mathrm{CDCl}_{3}, 600 \mathrm{MHz}\right)$

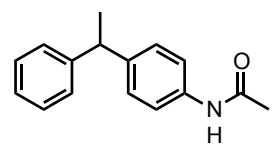

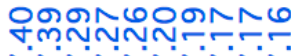

rininisiri

mNㅜㅇㅜ

ச்சேチ்

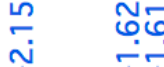

${ }^{h}$

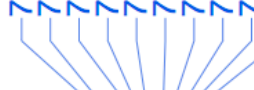

|

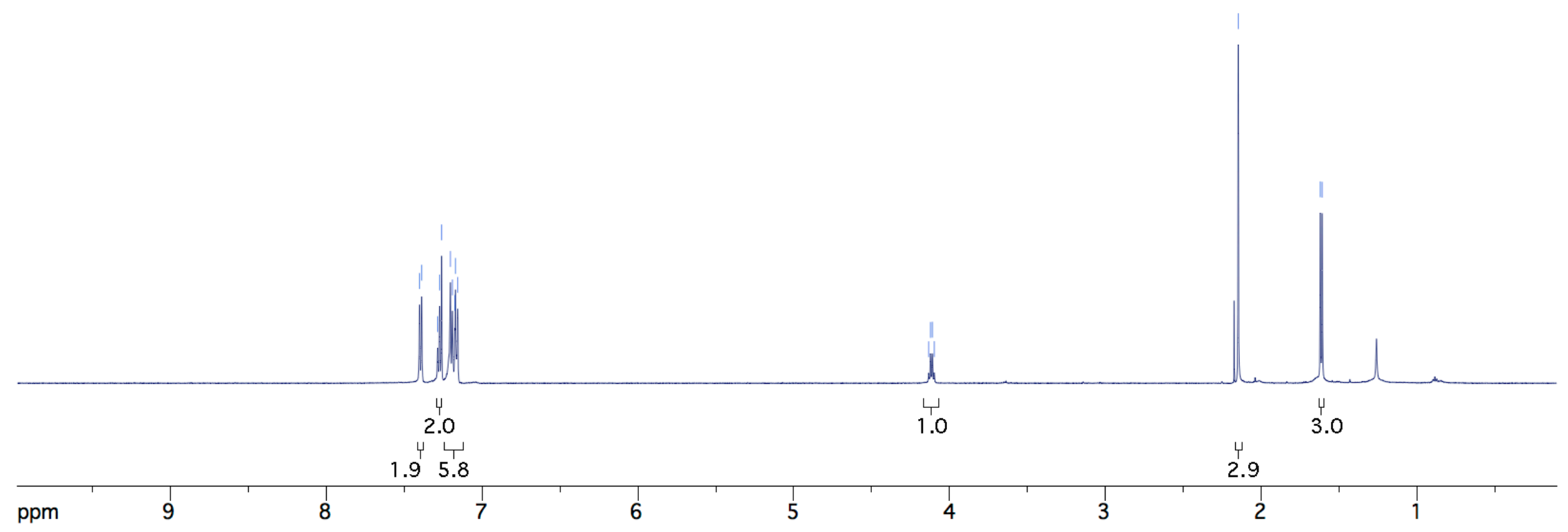



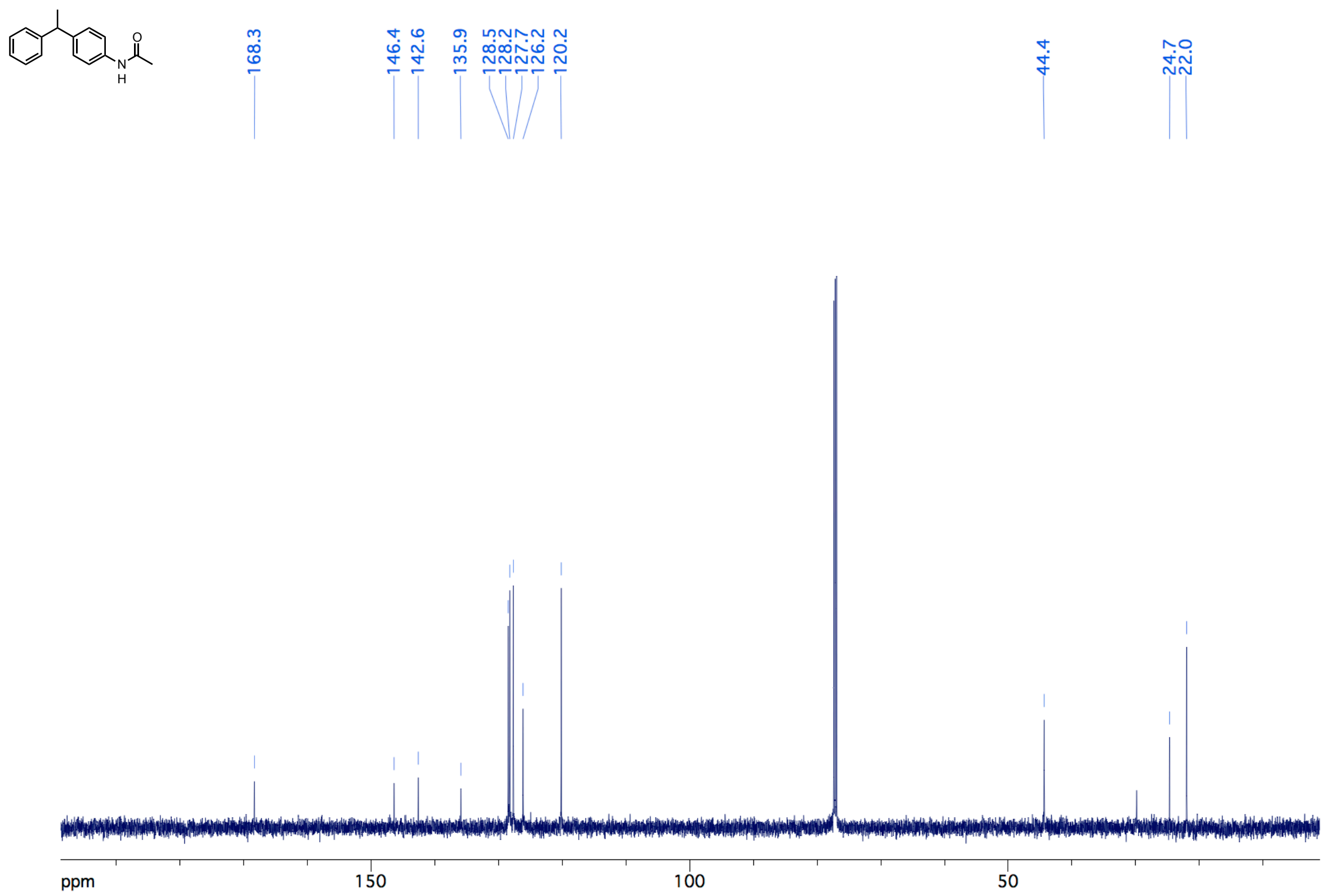

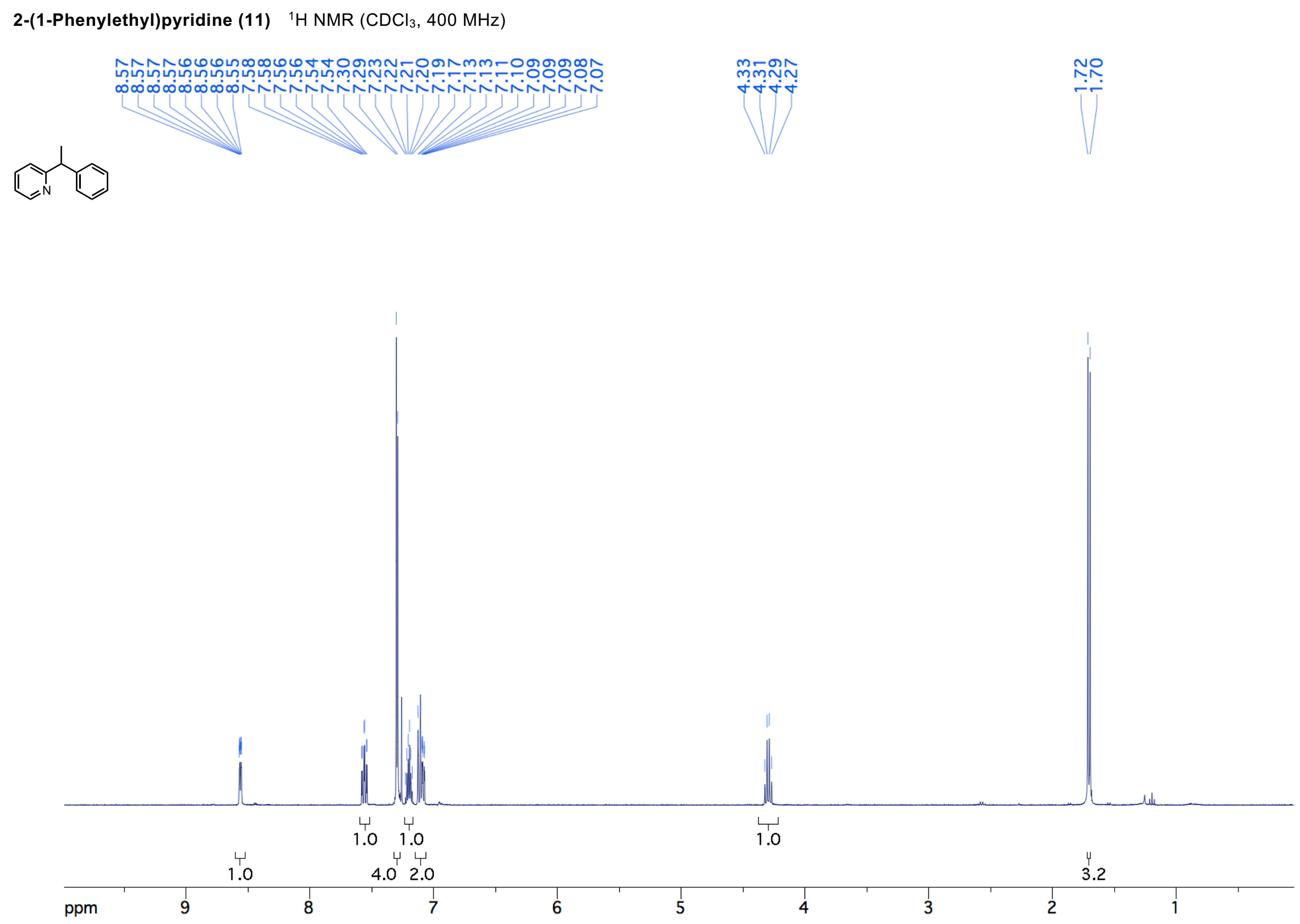

125 
2-(1-Phenylethyl)pyridine (11) ${ }^{13} \mathrm{C} \mathrm{NMR}\left(\mathrm{CDCl}_{3}, 100 \mathrm{MHz}\right)$

11.

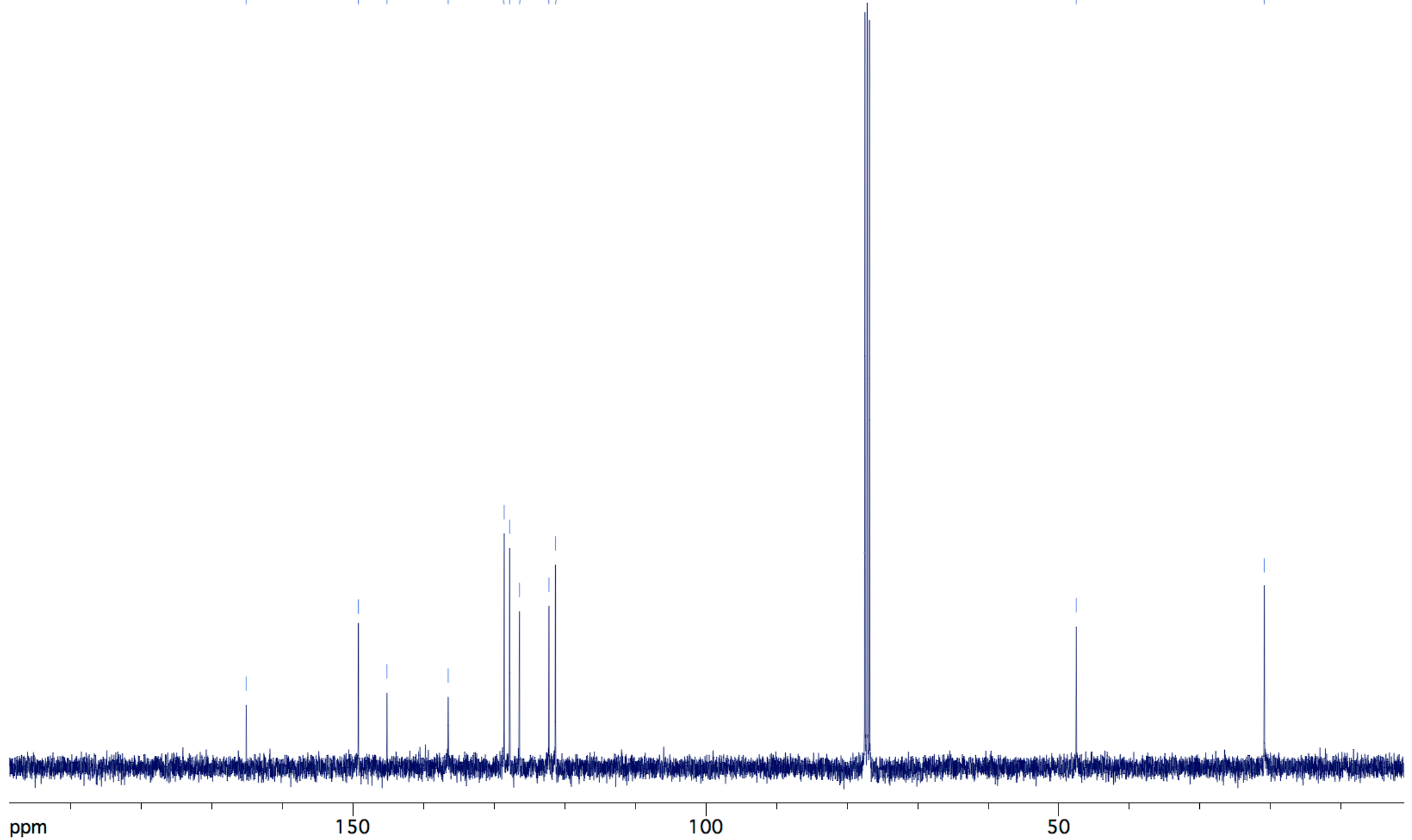


1-Methyl-2-(1-phenylethyl)benzene (12) ${ }^{1} \mathrm{H} \mathrm{NMR}\left(\mathrm{CDCl}_{3}, 400 \mathrm{MHz}\right)$
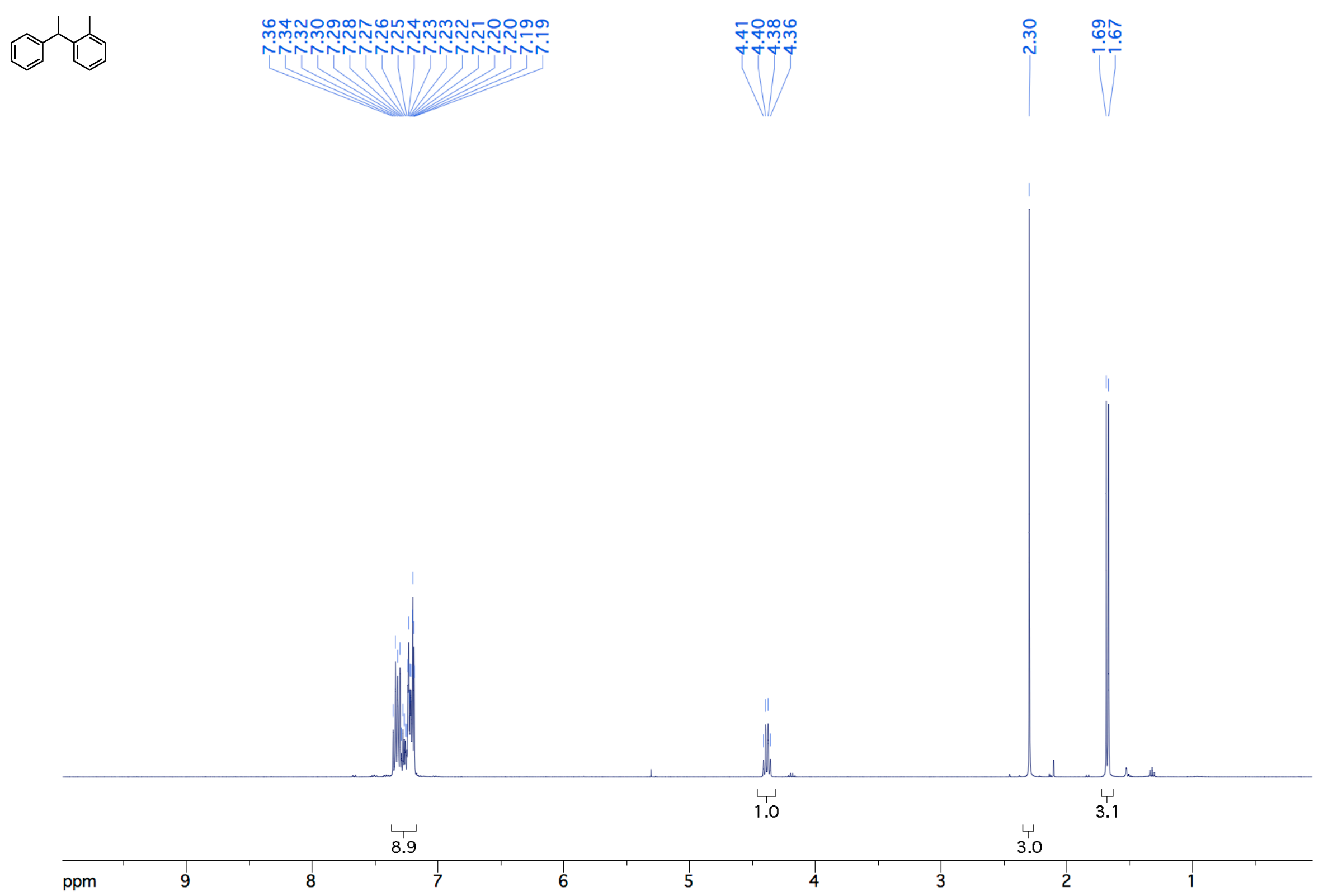

127 
1-Methyl-2-(1-phenylethyl)benzene (12) ${ }^{13} \mathrm{C} \mathrm{NMR}\left(\mathrm{CDCl}_{3}, 100 \mathrm{MHz}\right)$
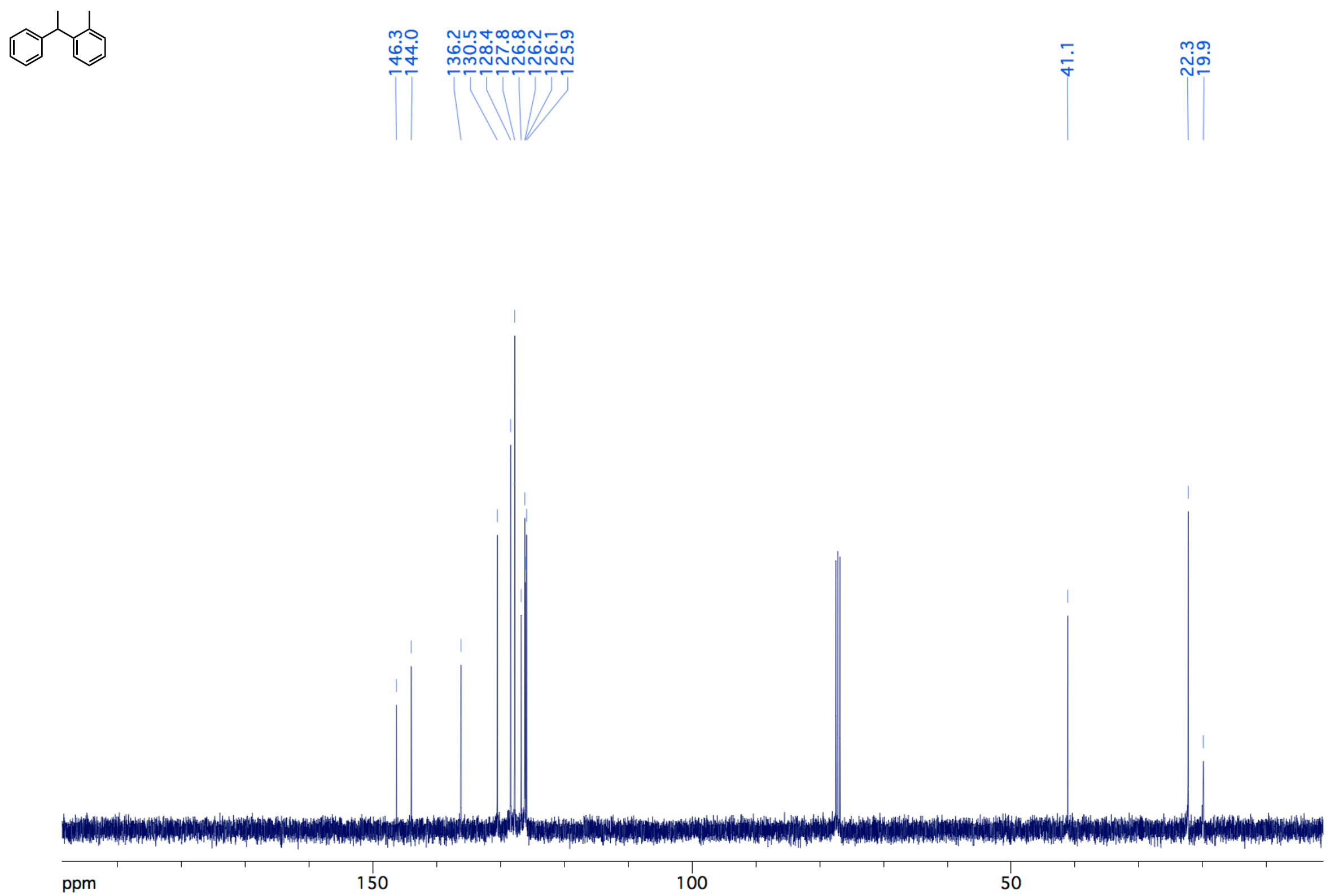

128 
1-Methyl-3-(1-phenylethyl)benzene (13) ${ }^{1} \mathrm{H} \mathrm{NMR}\left(\mathrm{CDCl}_{3}, 400 \mathrm{MHz}\right)$
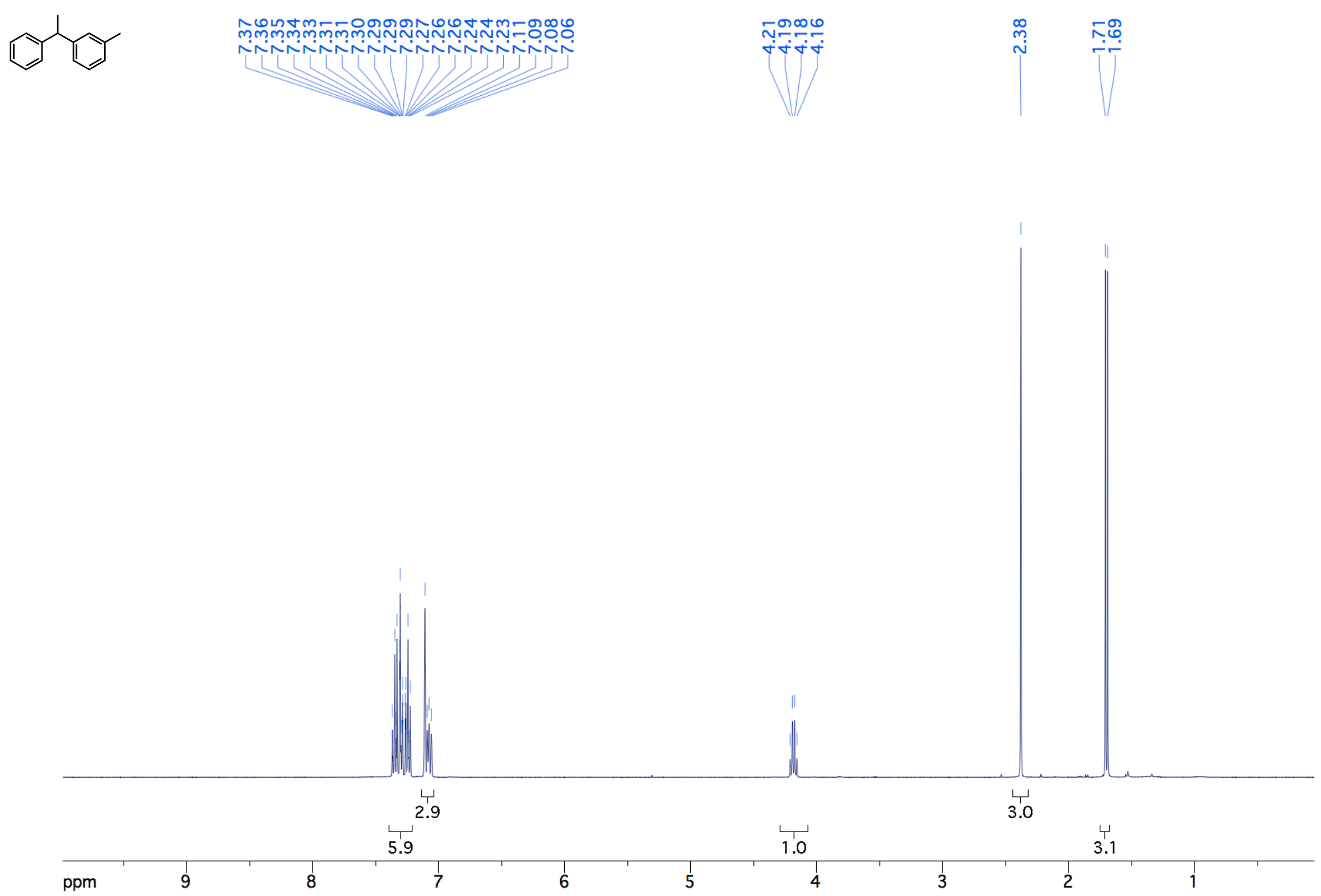

129 
1-Methyl-3-(1-phenylethyl)benzene (13) ${ }^{13} \mathrm{C} \mathrm{NMR}\left(\mathrm{CDCl}_{3}, 100 \mathrm{MHz}\right)$
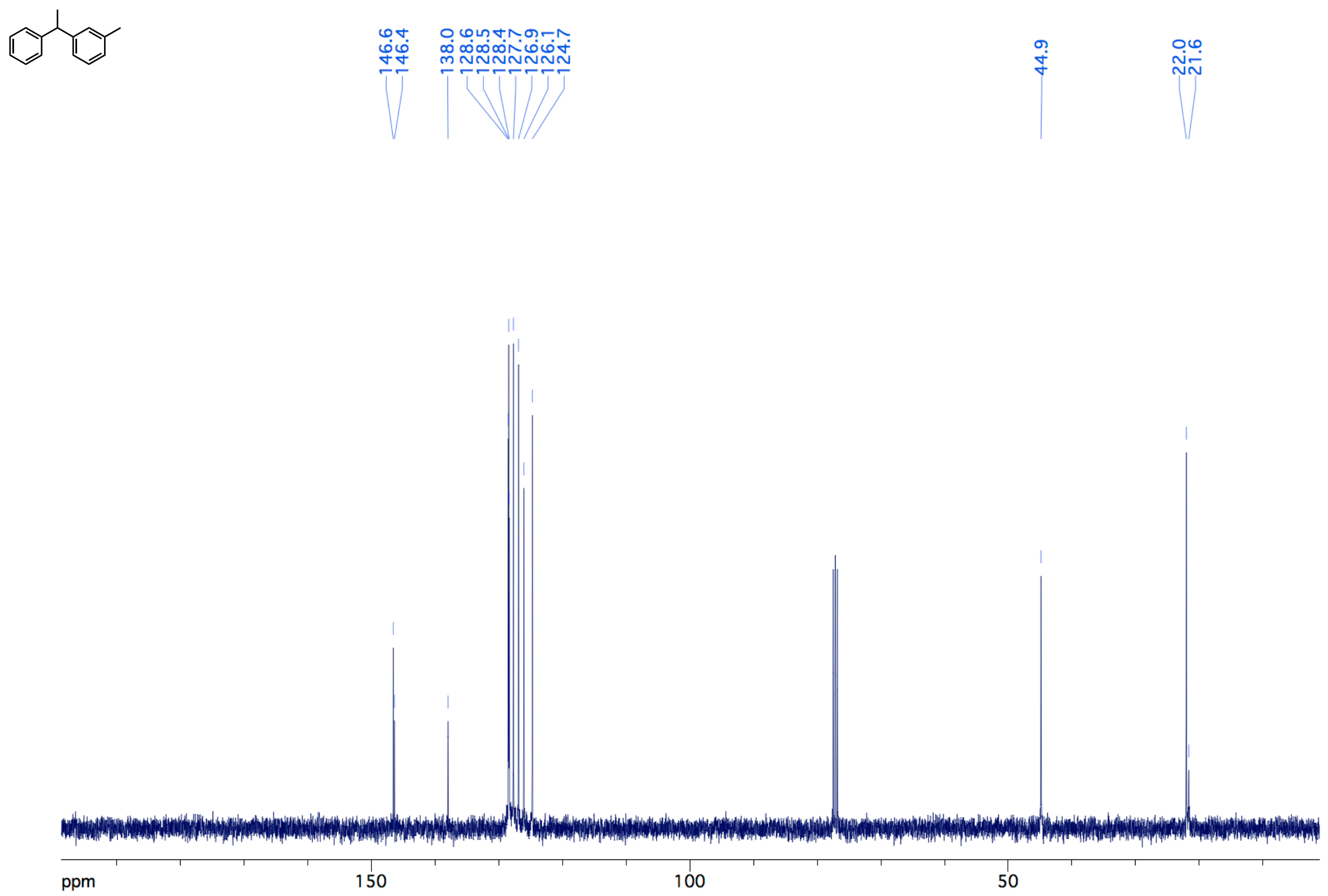

130 
1-Methyl-4-(1-phenylethyl)benzene (14) ${ }^{1} \mathrm{H} \mathrm{NMR}\left(\mathrm{CDCl}_{3}, 400 \mathrm{MHz}\right)$
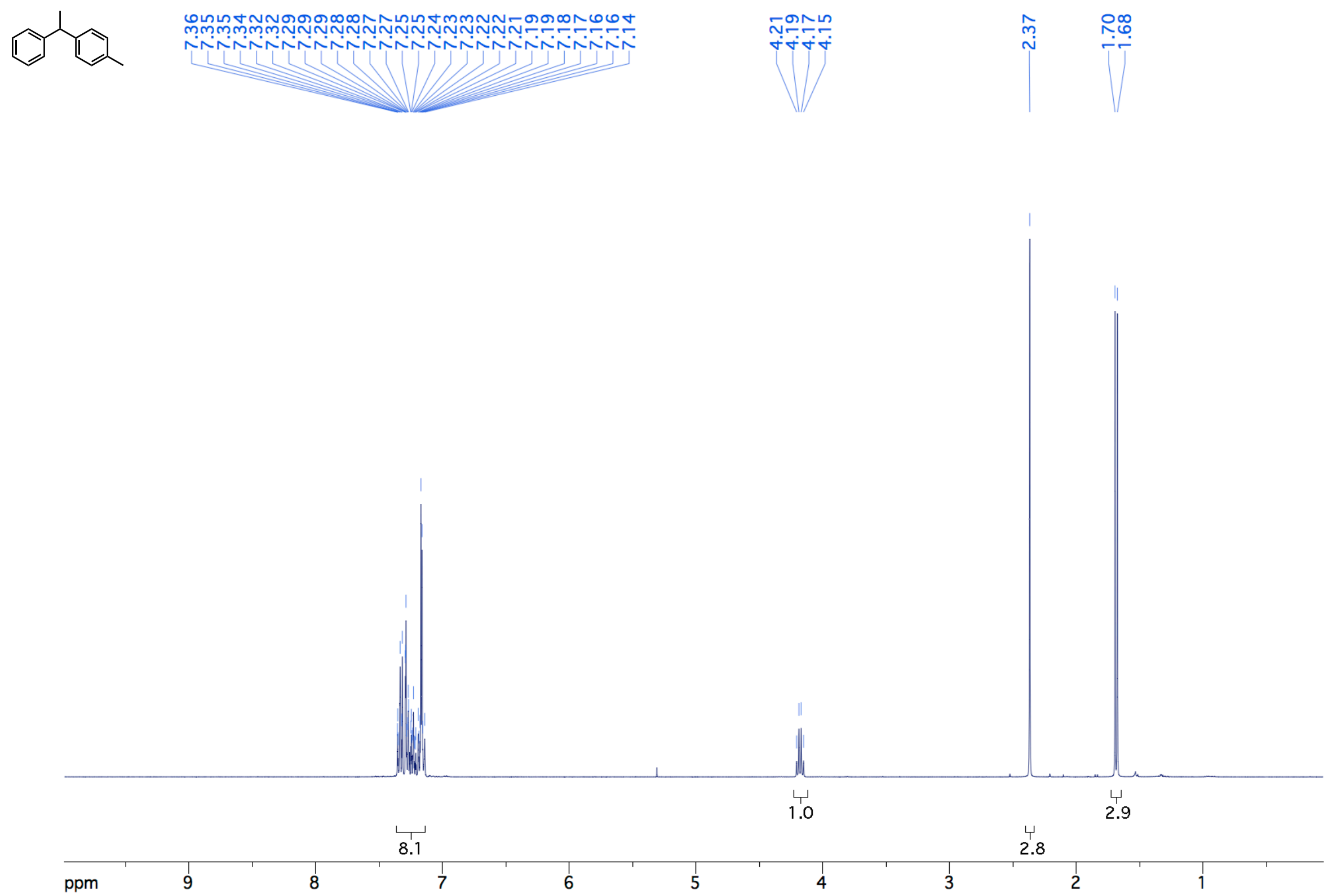

131 
1-Methyl-4-(1-phenylethyl)benzene (14) ${ }^{13} \mathrm{C} \mathrm{NMR}\left(\mathrm{CDCl}_{3}, 100 \mathrm{MHz}\right)$
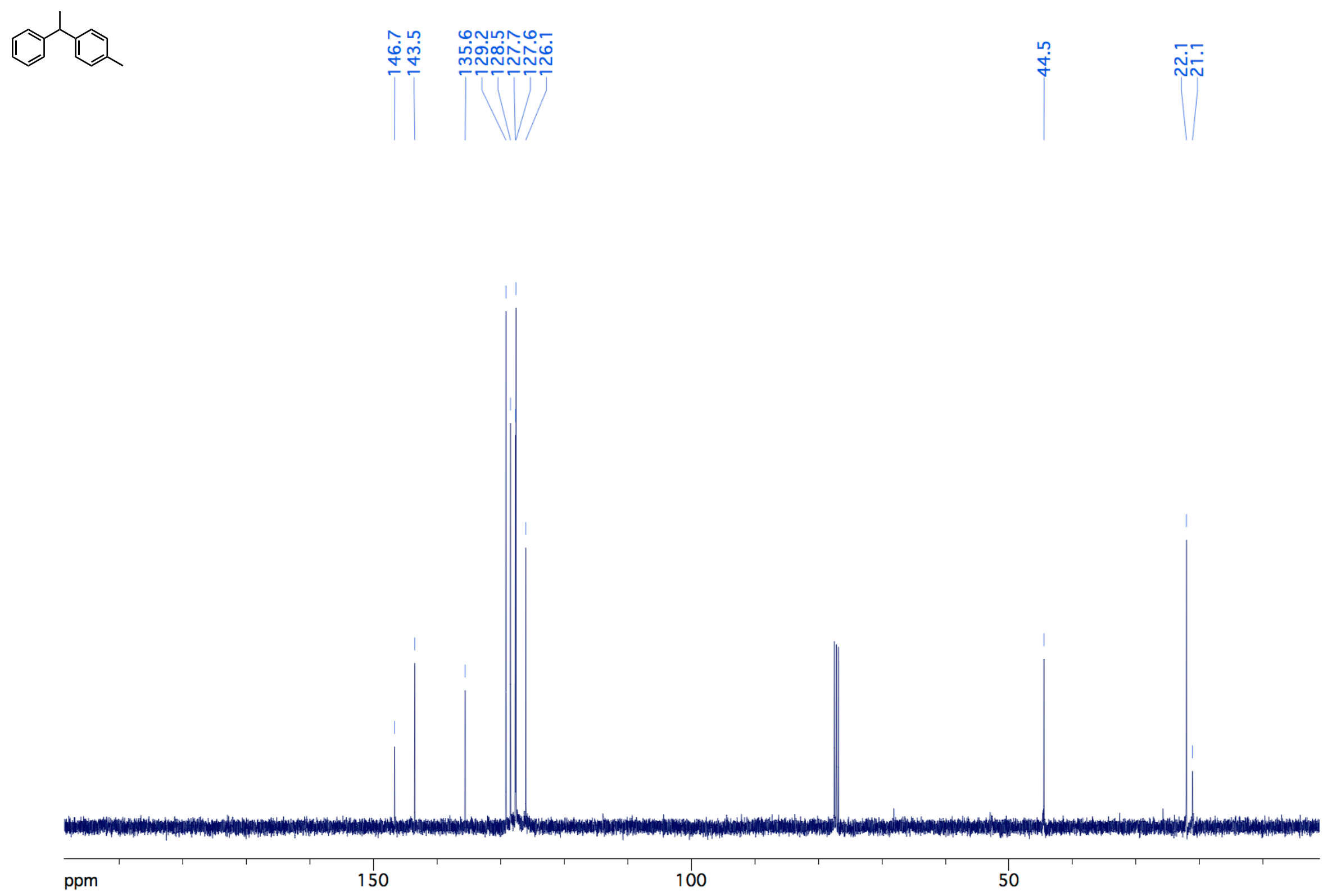

132 
11-(tert-Butyl)-4-(1-phenylethyl)benzene (15) $\quad{ }^{1} \mathrm{H} \mathrm{NMR}\left(\mathrm{CDCl}_{3}, 400 \mathrm{MHz}\right)$
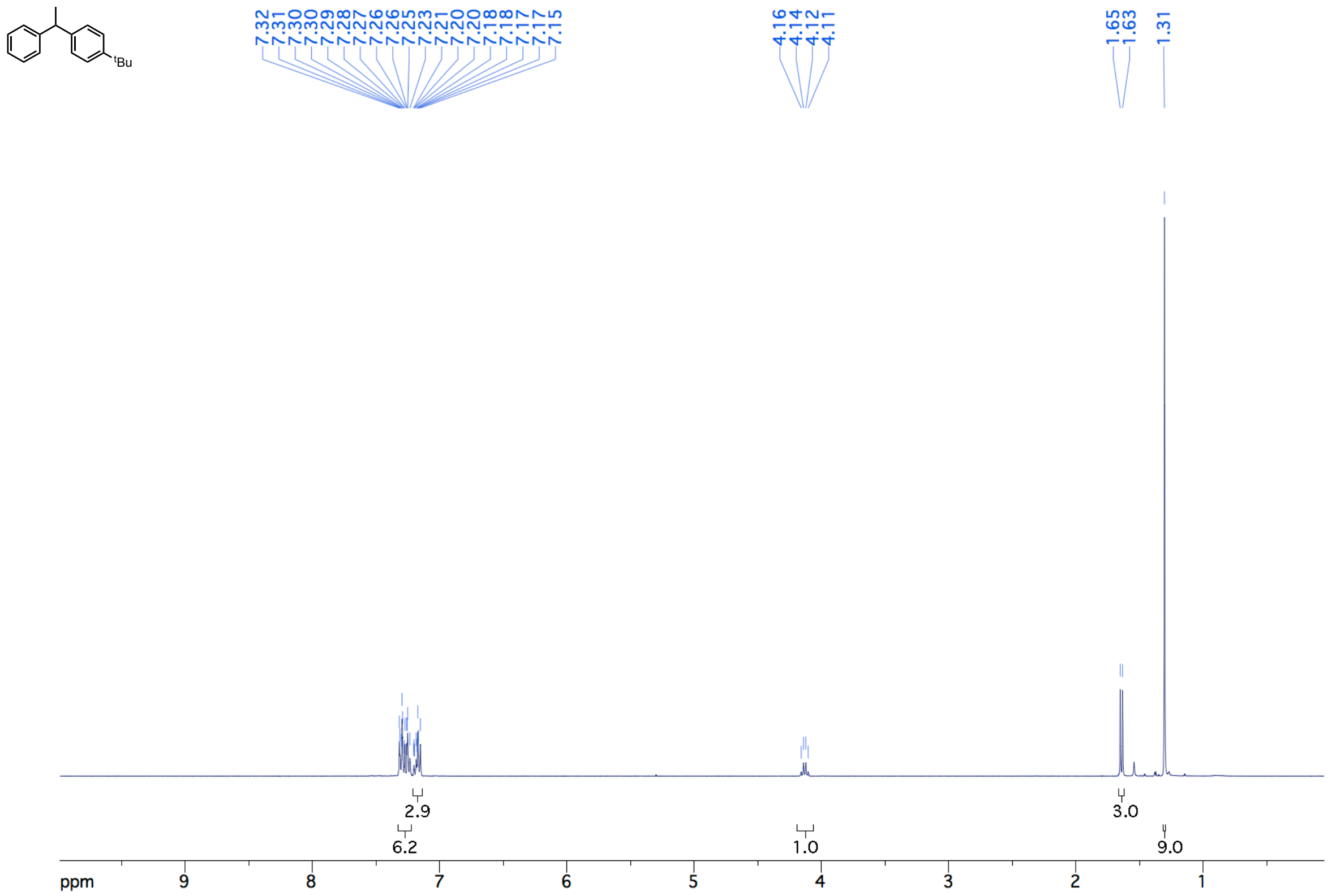
11-(tert-Butyl)-4-(1-phenylethyl)benzene (15) ${ }^{13} \mathrm{C} \mathrm{NMR}\left(\mathrm{CDCl}_{3}, 100 \mathrm{MHz}\right)$
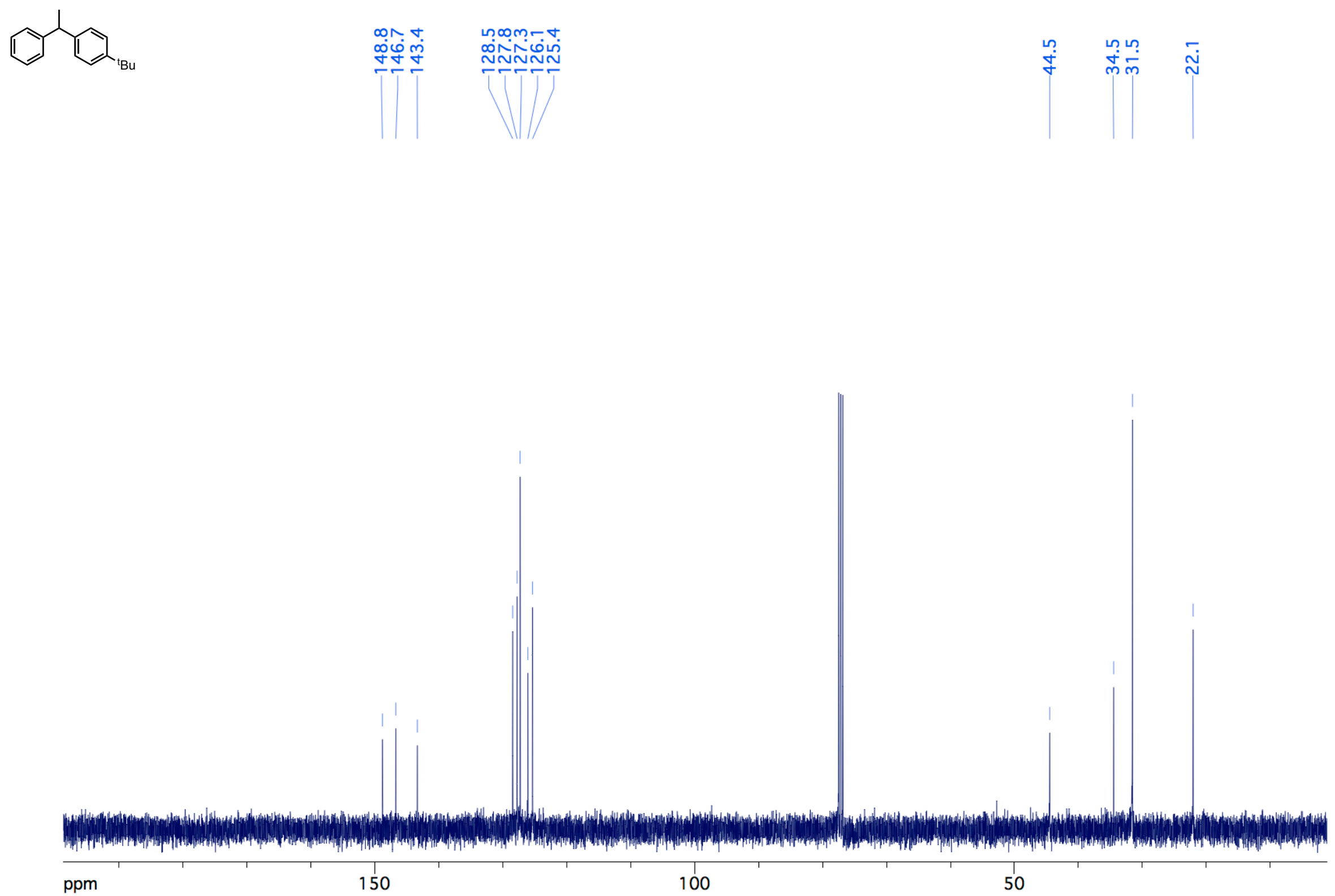


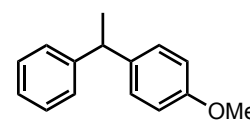

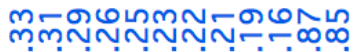

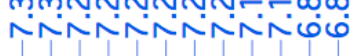

근두요

ச்சேசणं
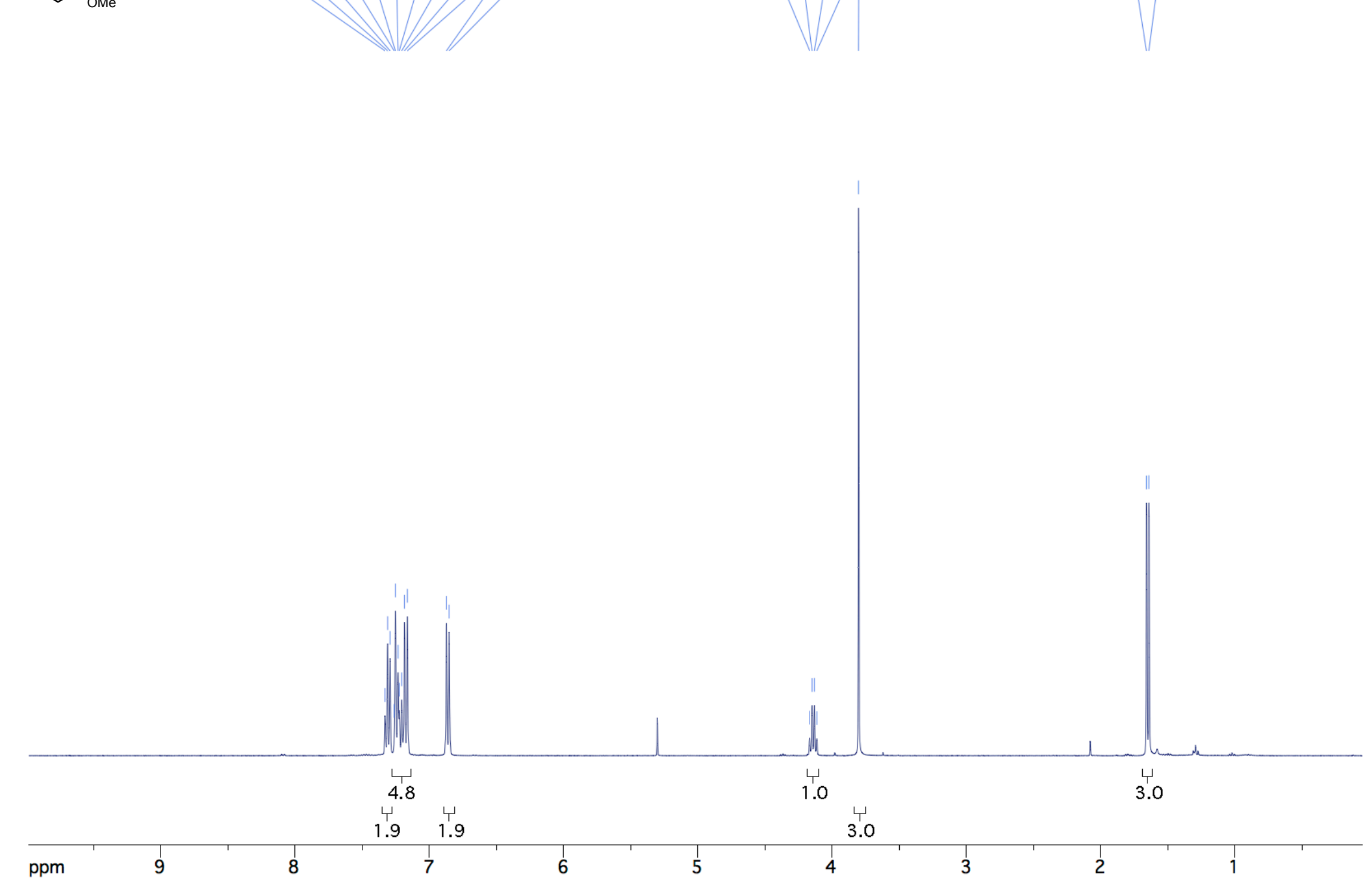

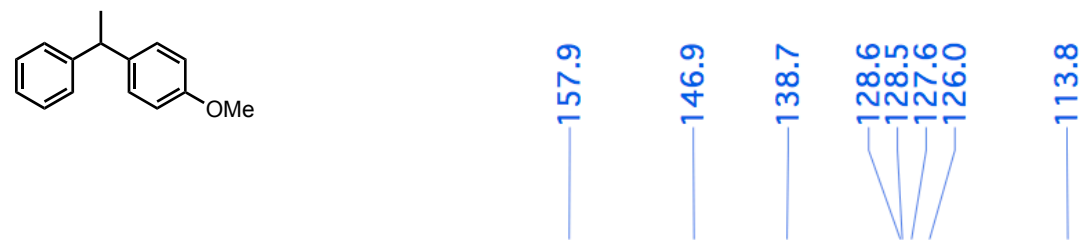

in

ָั

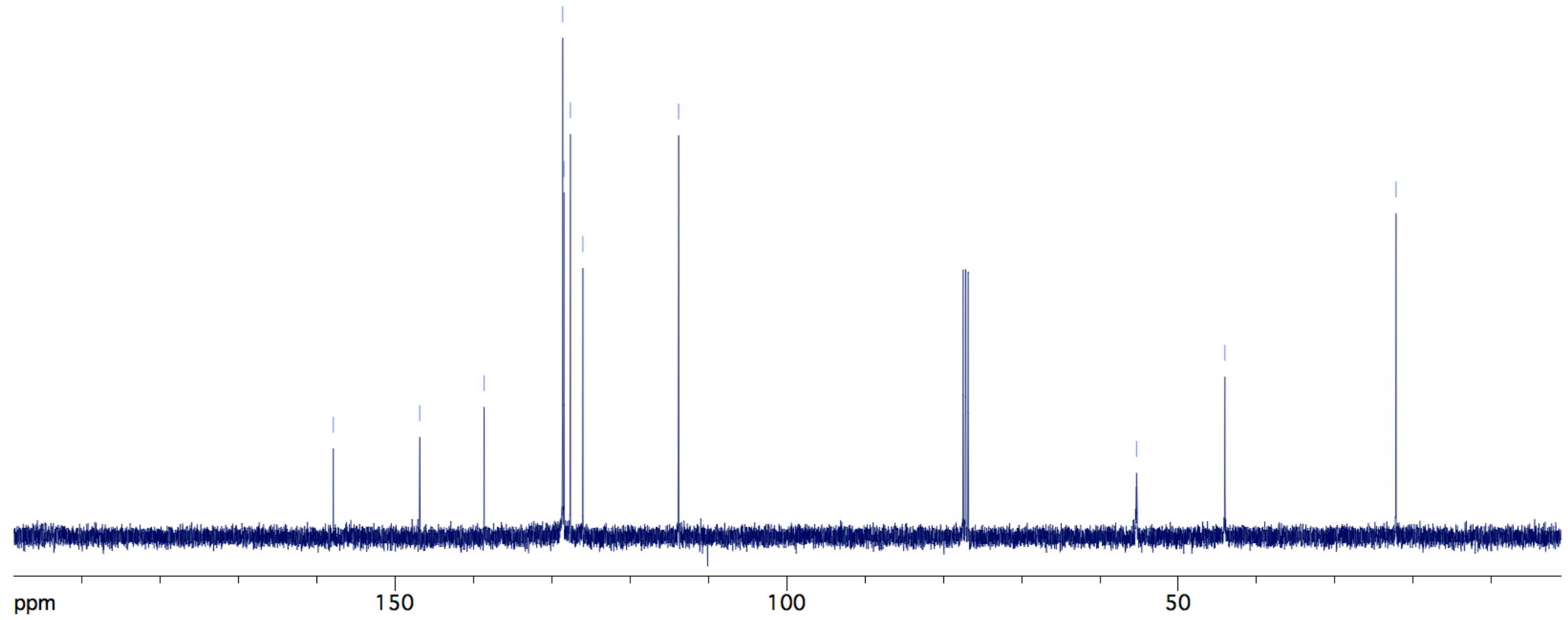



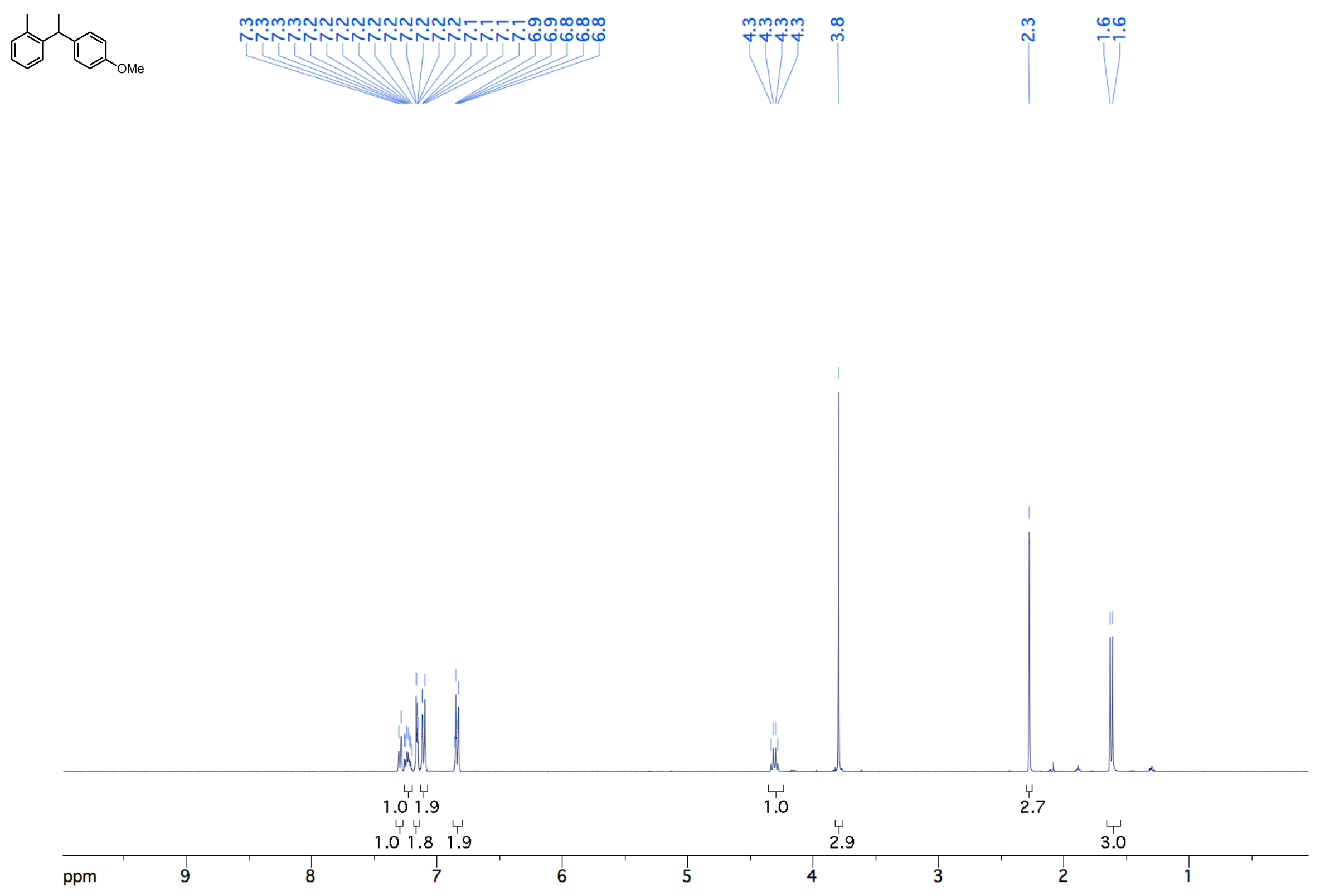

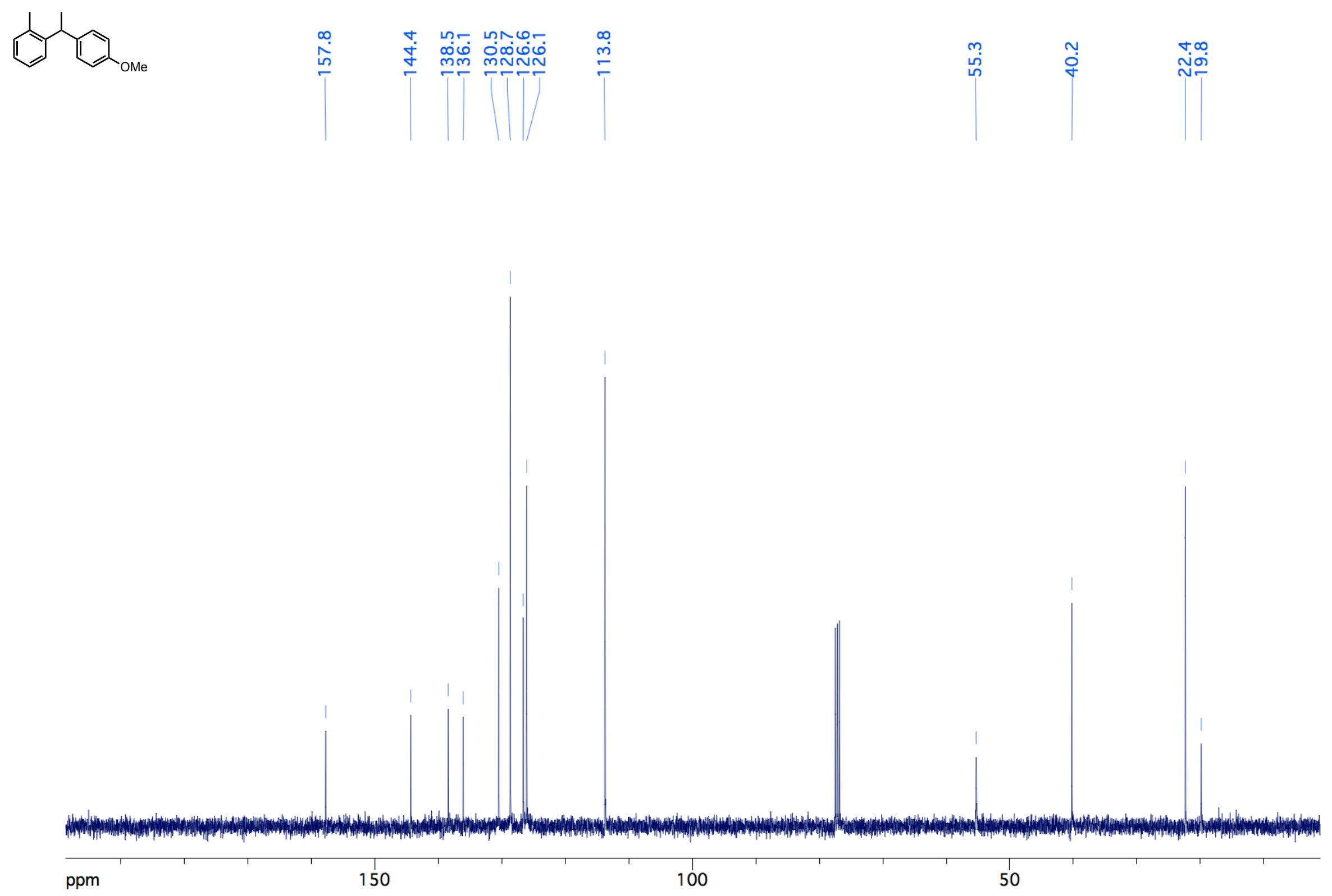


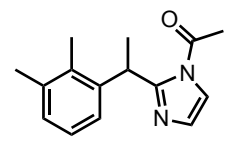

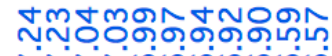

iNiniogiogio

Fอับำ

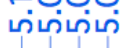

พับกั

i/

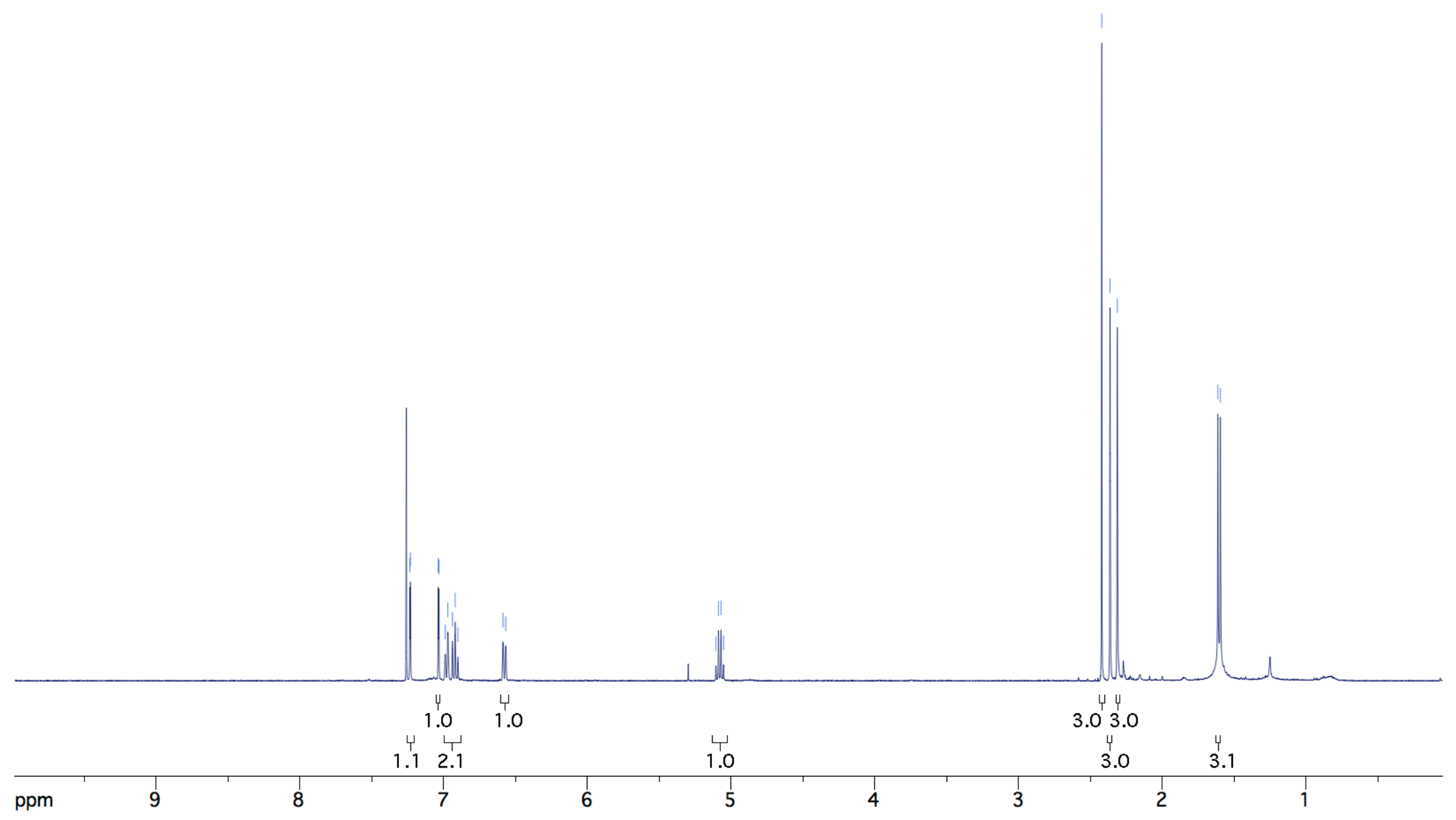



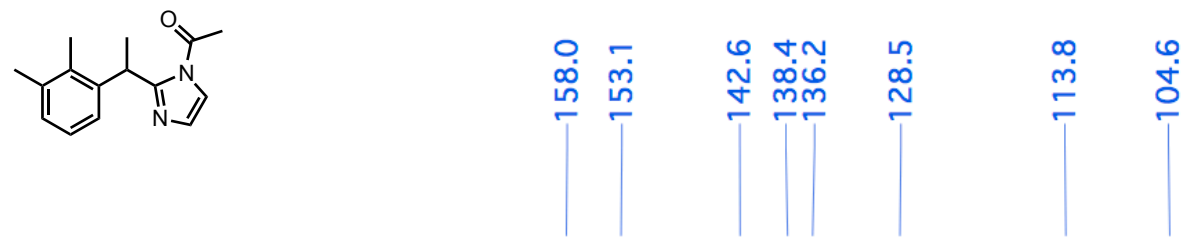

Oุ ำm

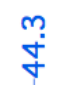

$\stackrel{\sim}{N}$

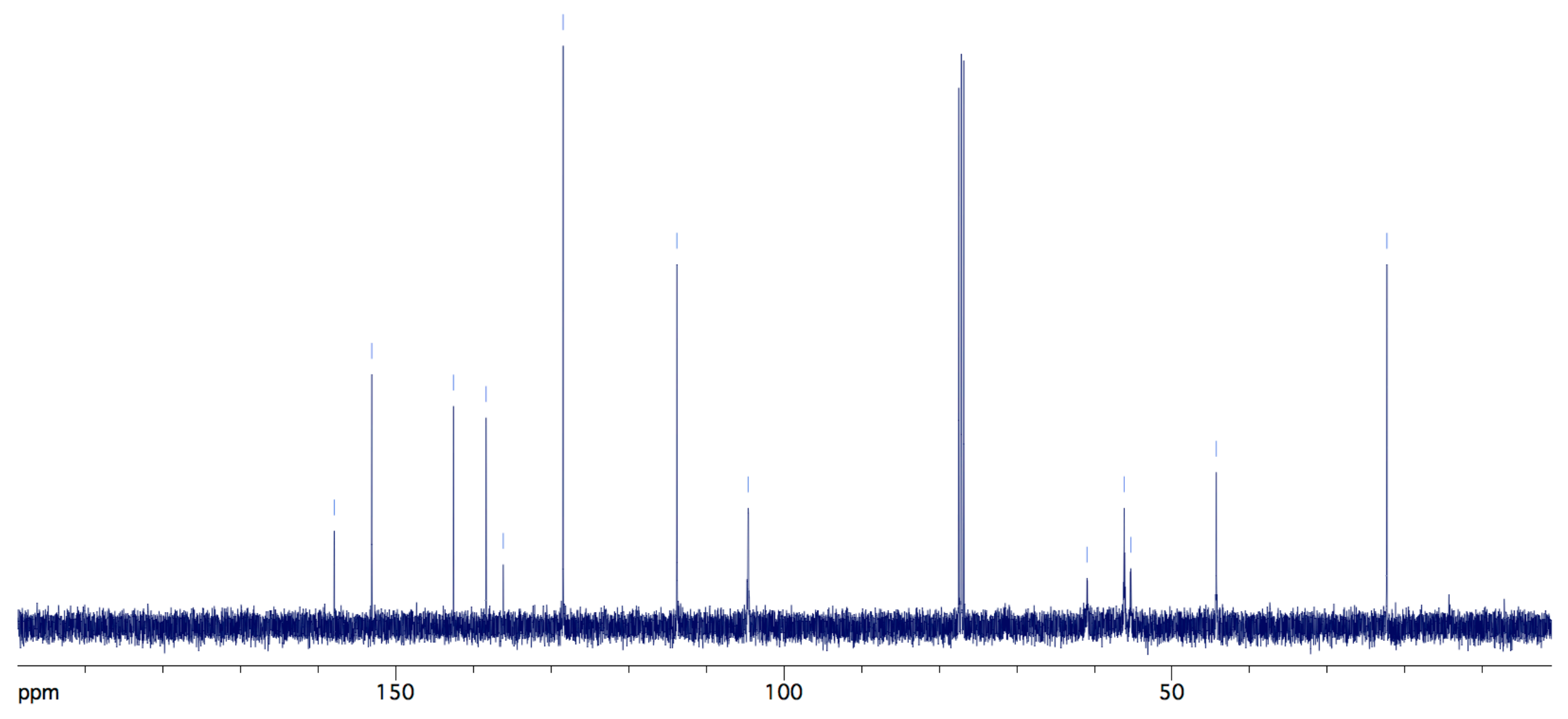


${ }^{1} \mathrm{H} \mathrm{NMR}\left(\mathrm{CDCl}_{3}, 600 \mathrm{MHz}\right)$
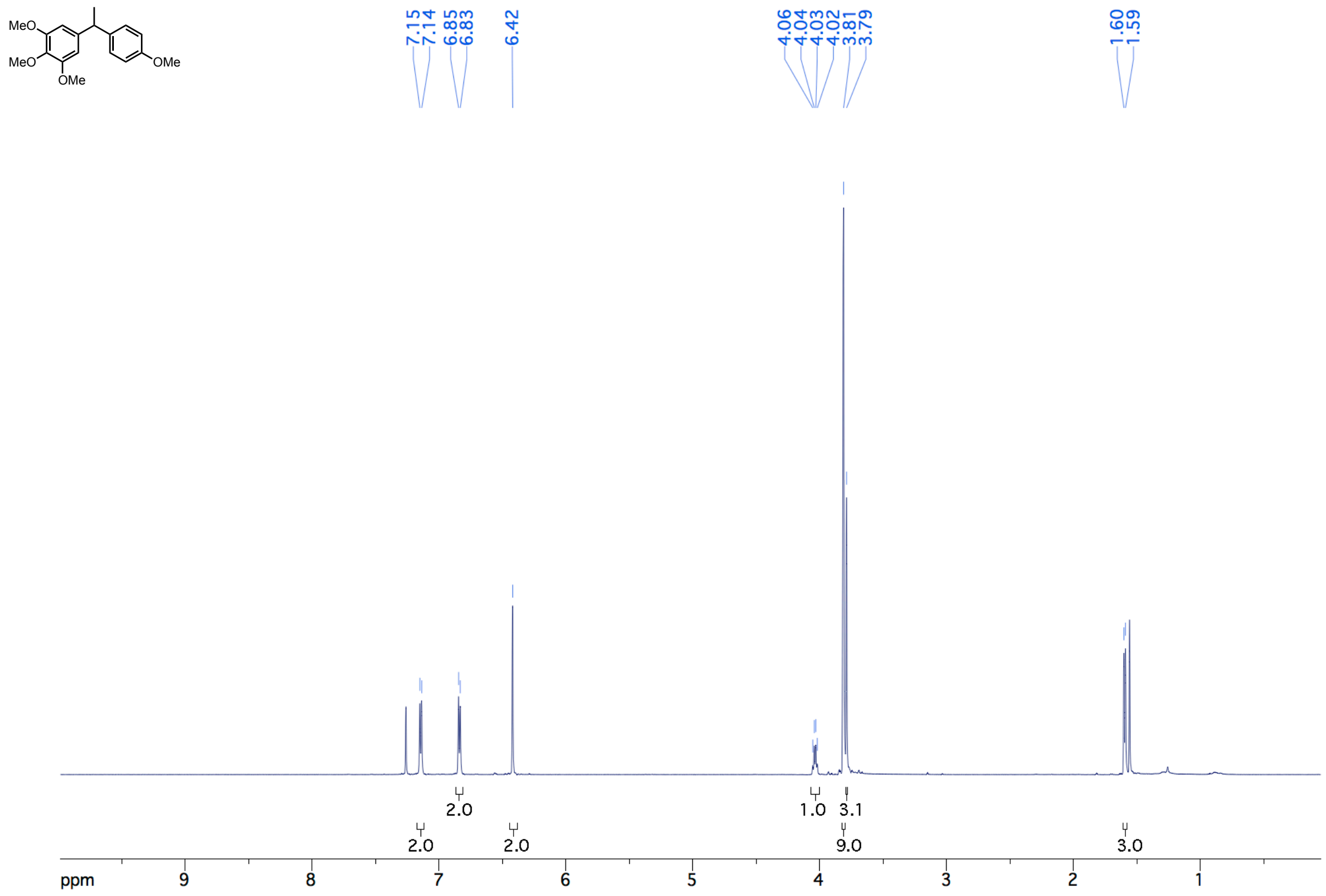


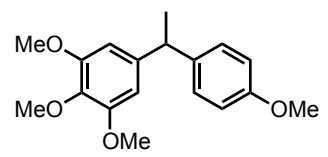

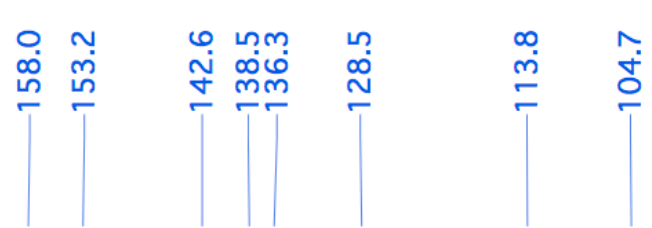

ำ ำ

$\stackrel{\mathfrak{*}}{+}$

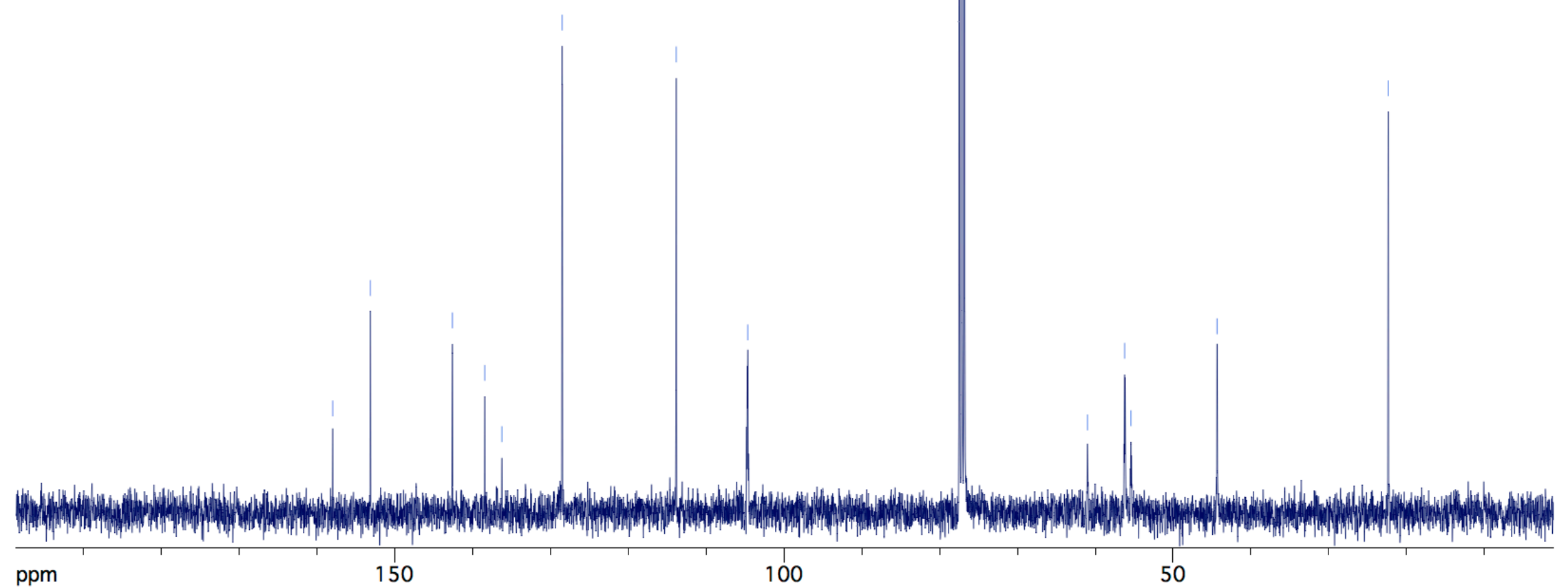


Propane-1,1-diyldibenzene (20) ${ }^{1} \mathrm{H}$ NMR $\left(\mathrm{CDCl}_{3}, 400 \mathrm{MHz}\right)$
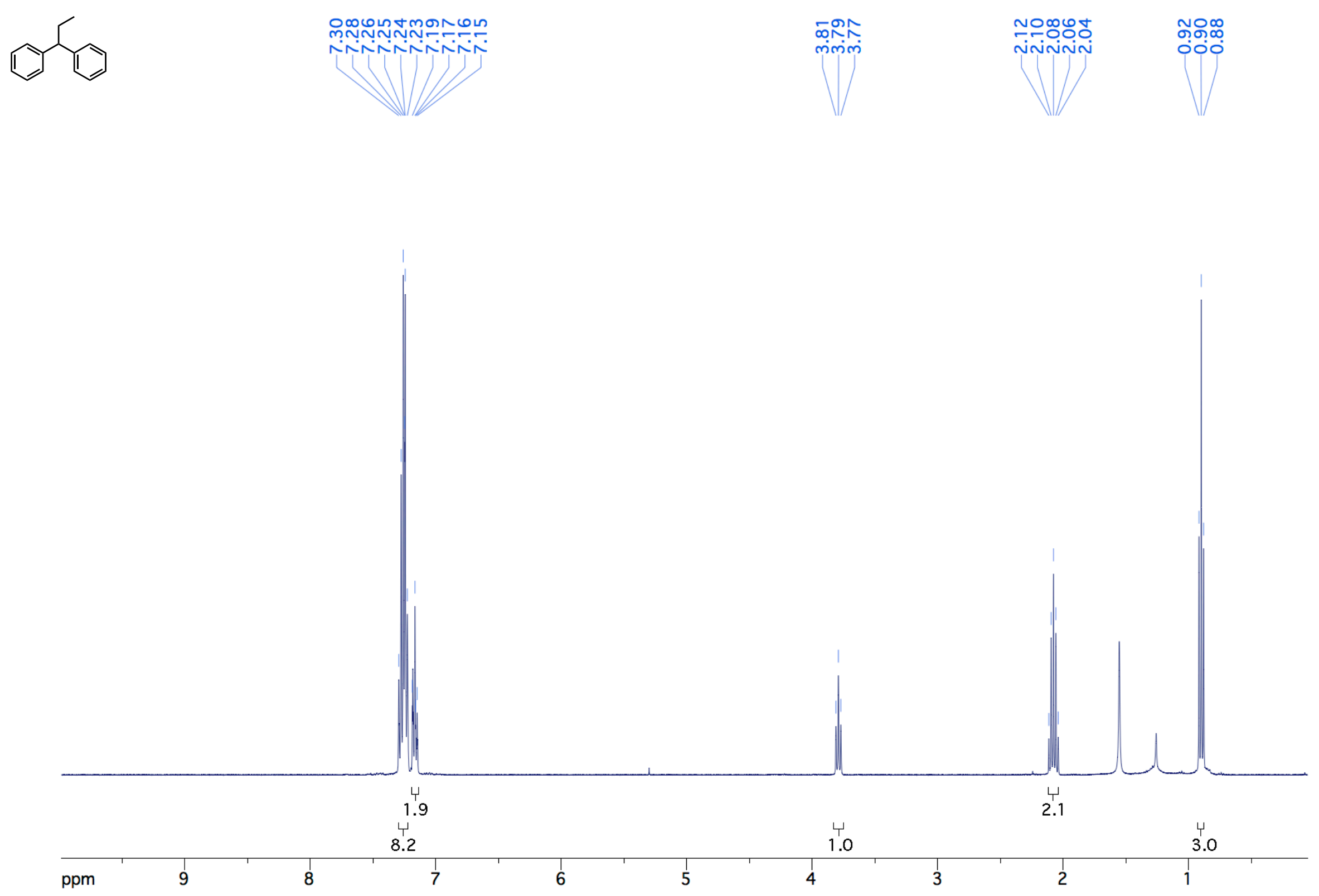
Propane-1,1-diyldibenzene (20) ${ }^{13} \mathrm{C}$ NMR $\left(\mathrm{CDCl}_{3}, 100 \mathrm{MHz}\right)$
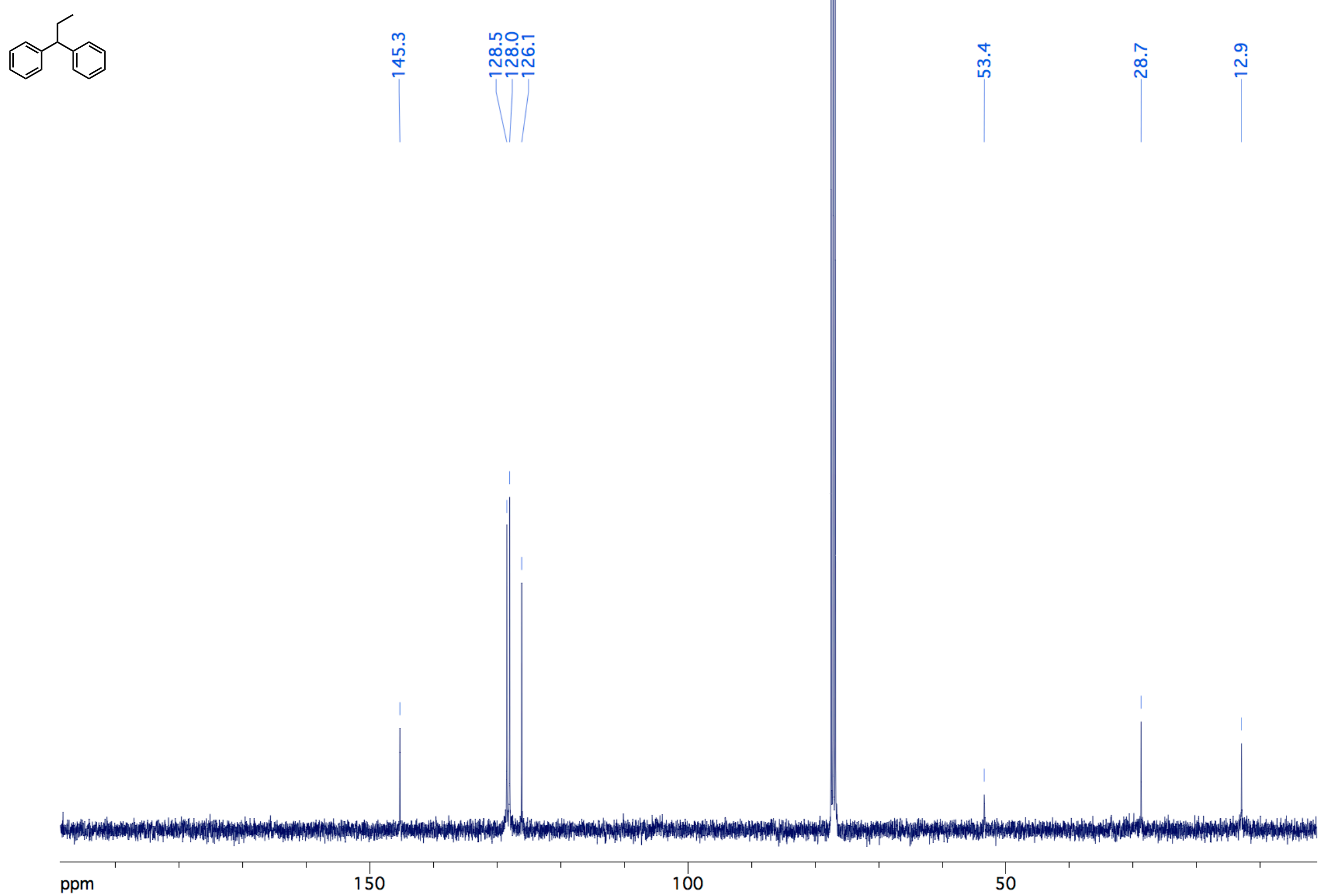

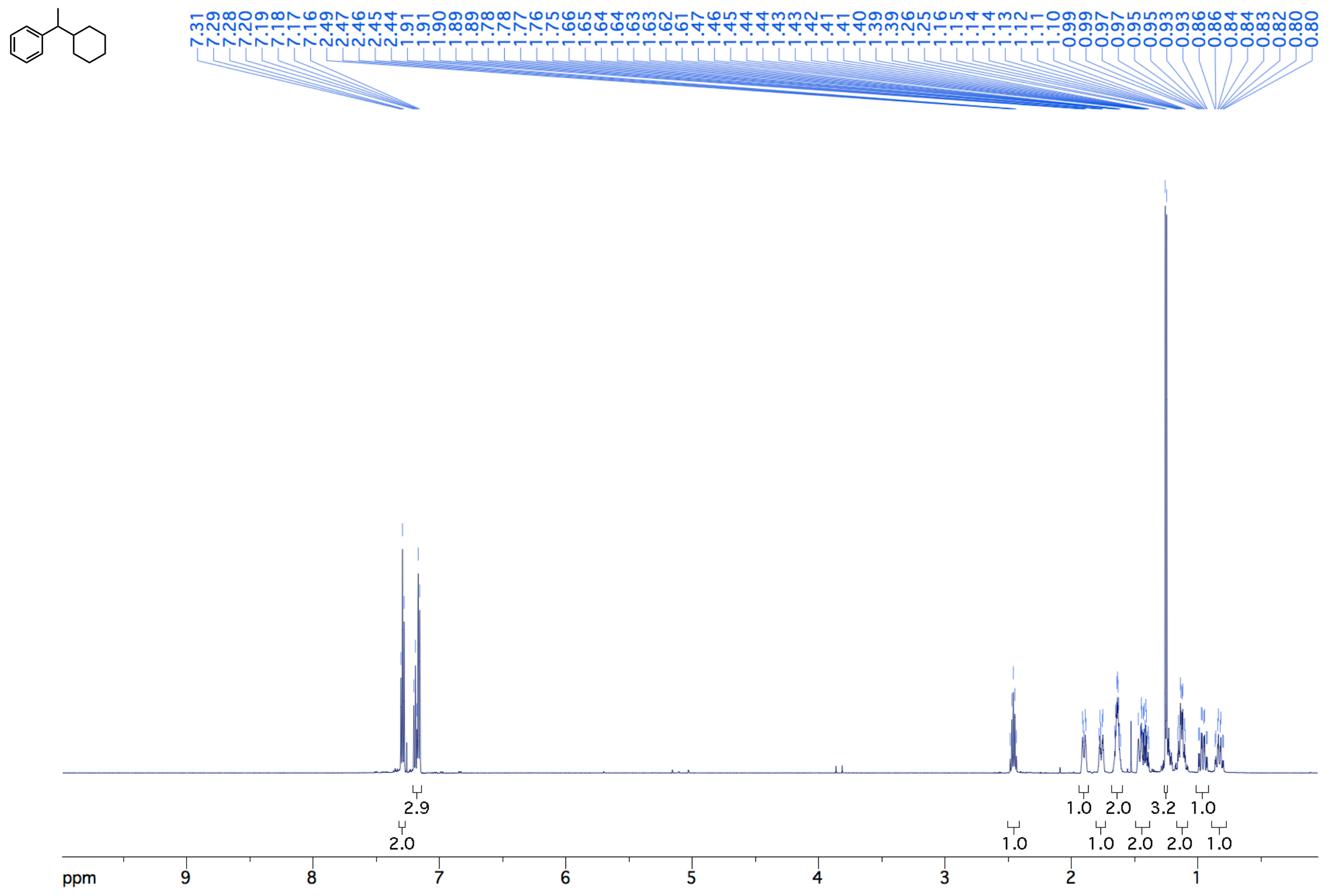

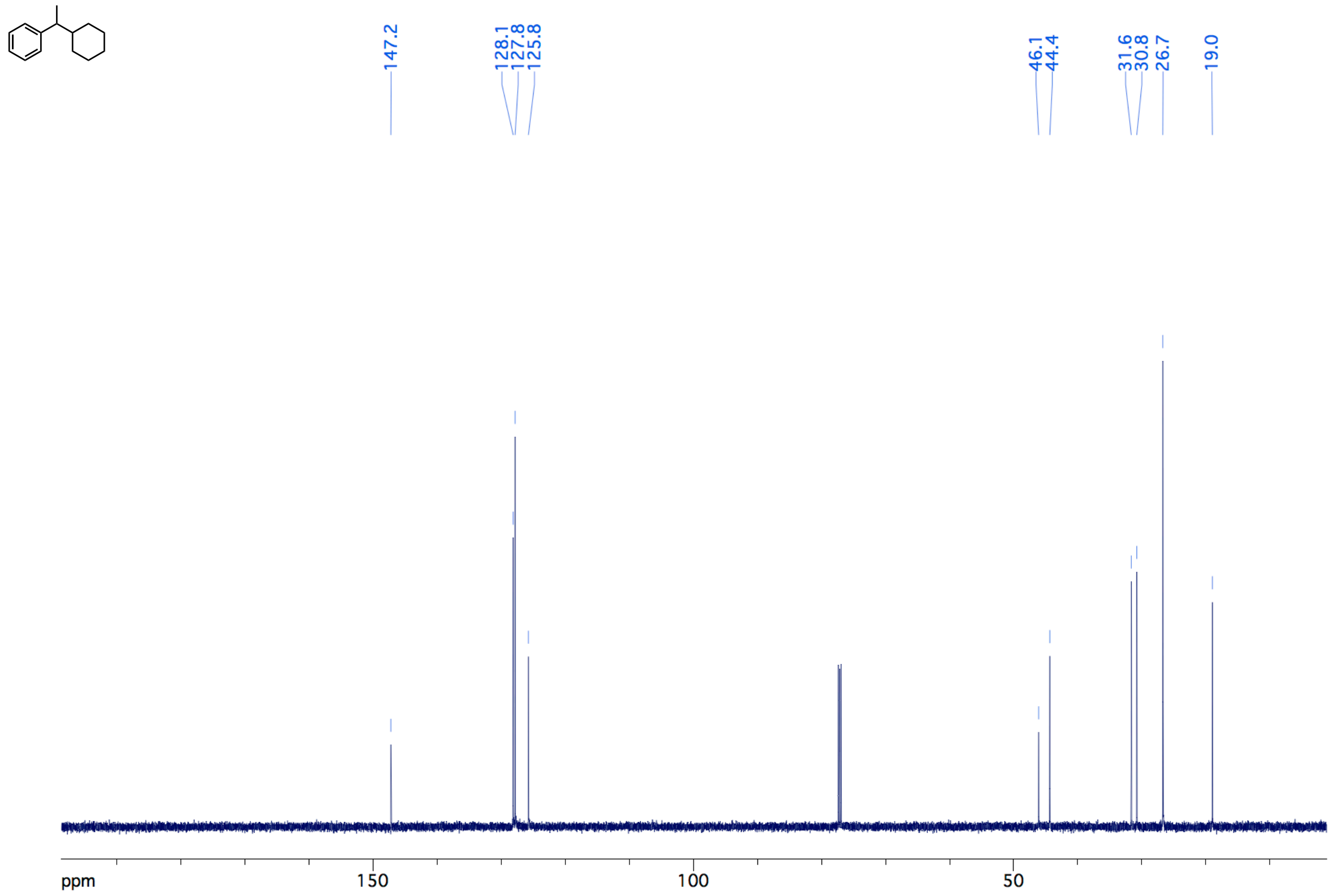

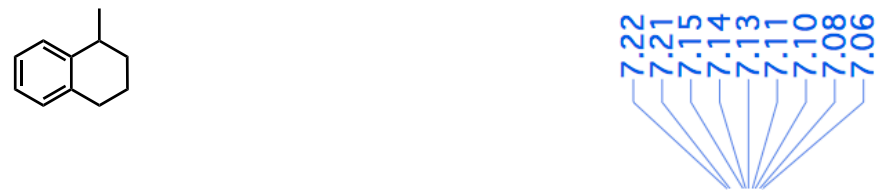

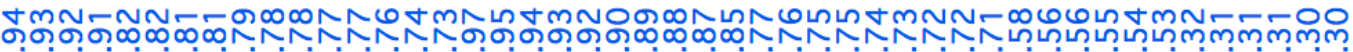

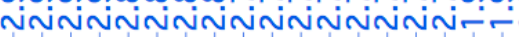
-

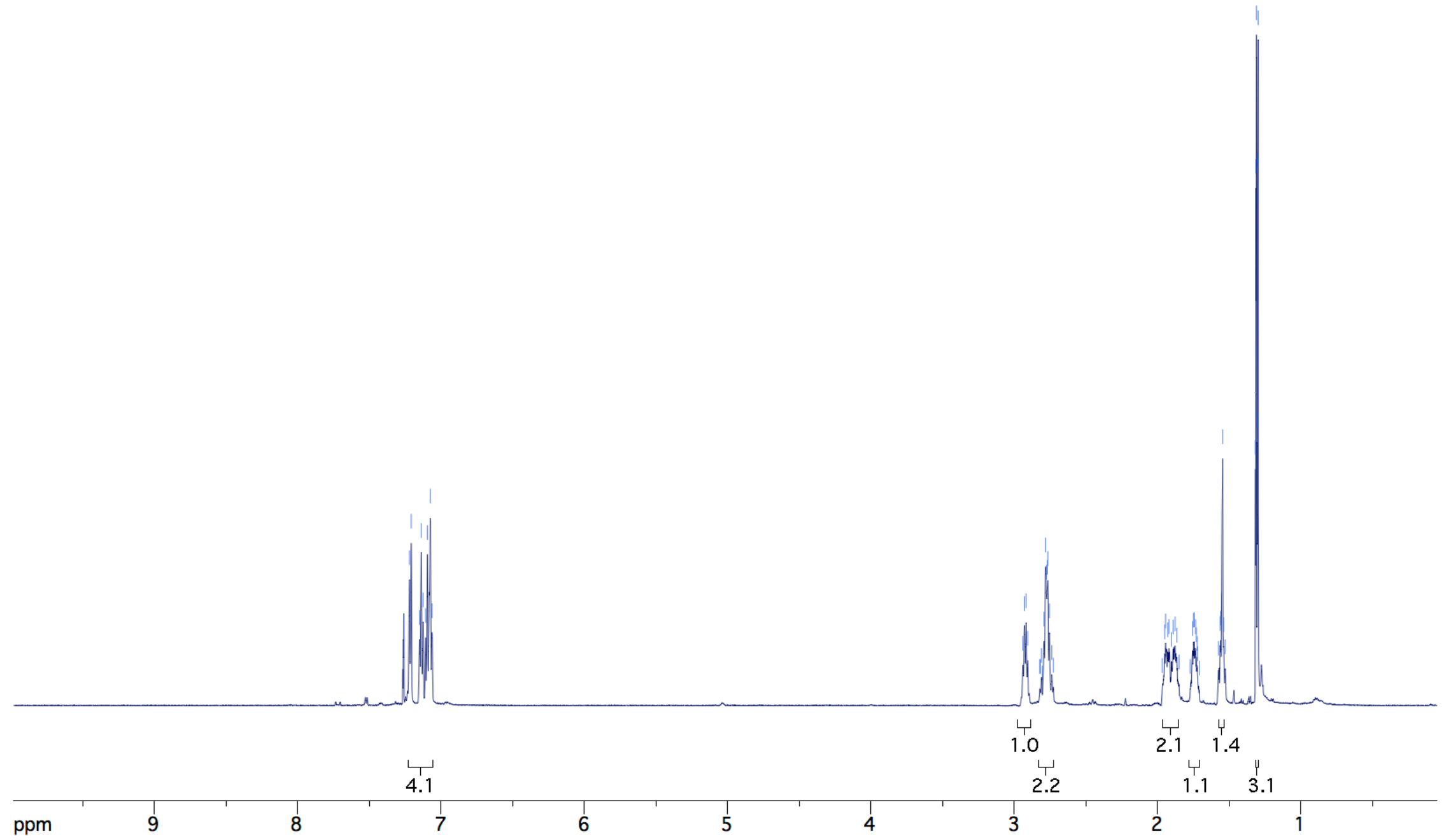


1-Methylene-1,2,3,4-tetrahydronaphthalene (22) ${ }^{13} \mathrm{C} \mathrm{NMR}\left(\mathrm{CDCl}_{3}, 151 \mathrm{MHz}\right)$
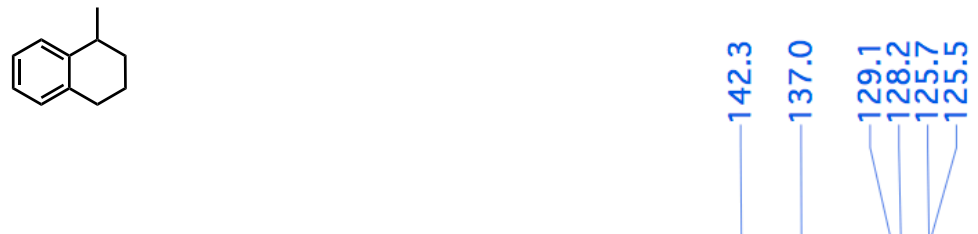

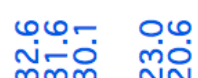

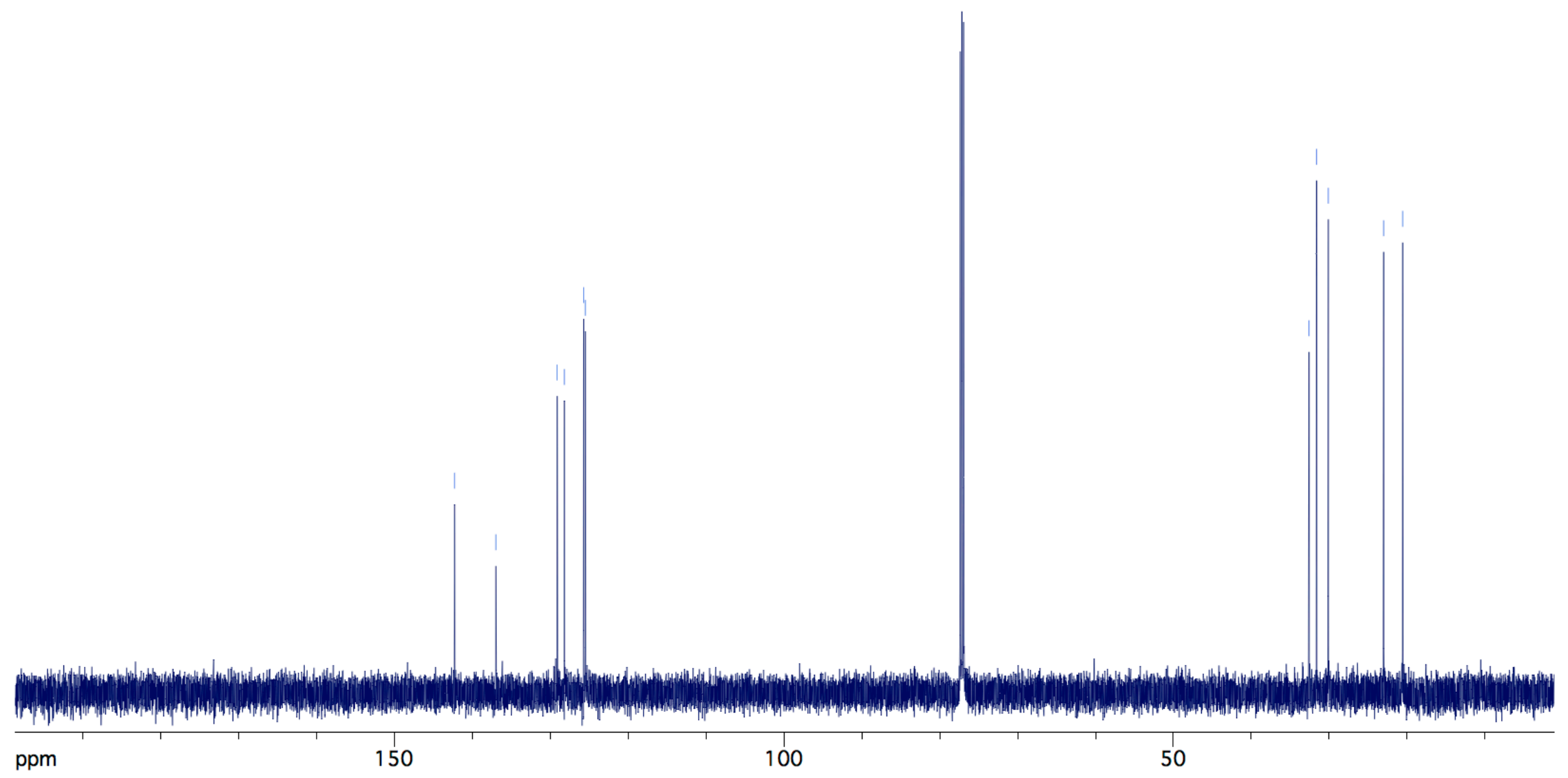



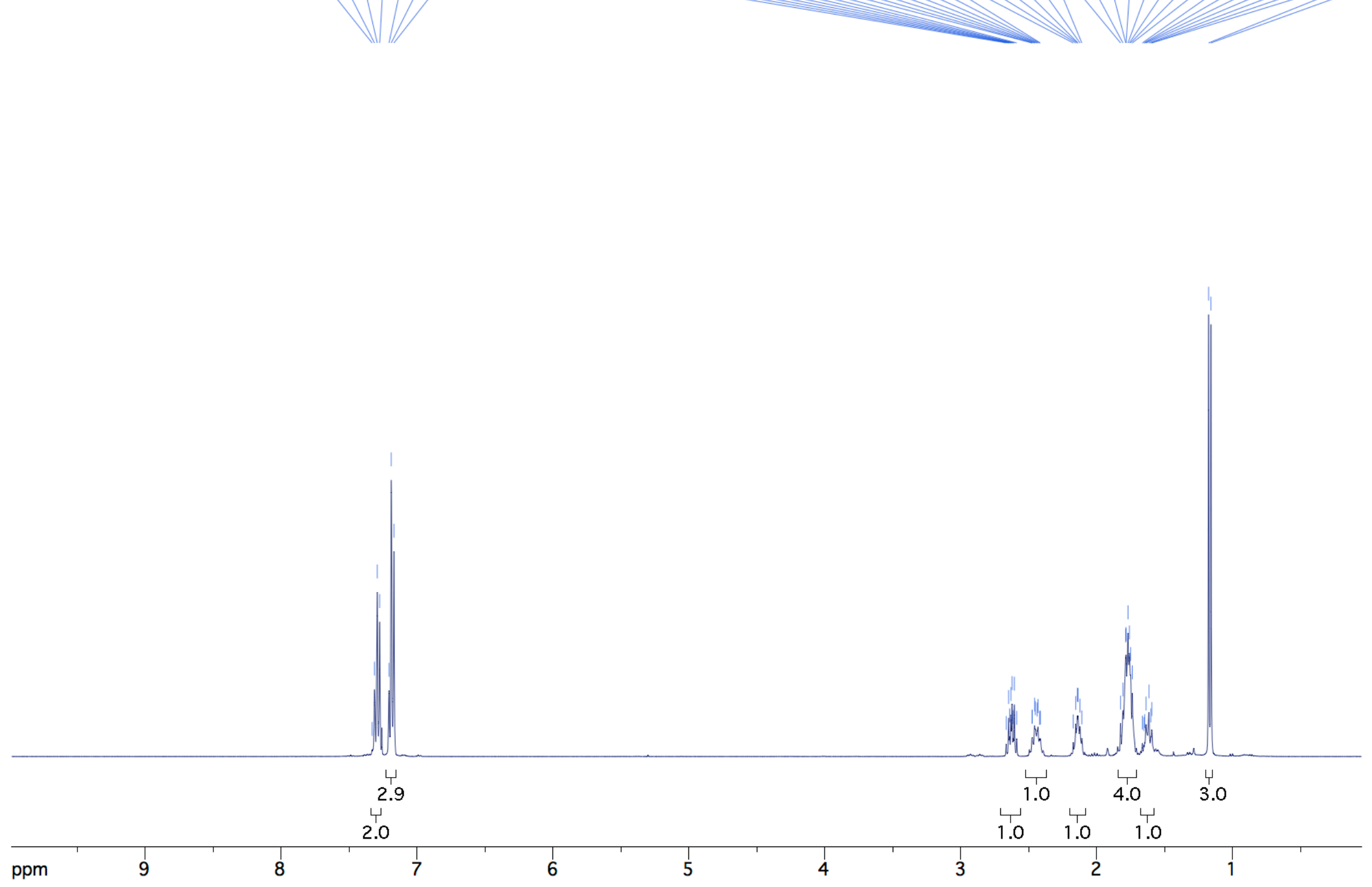


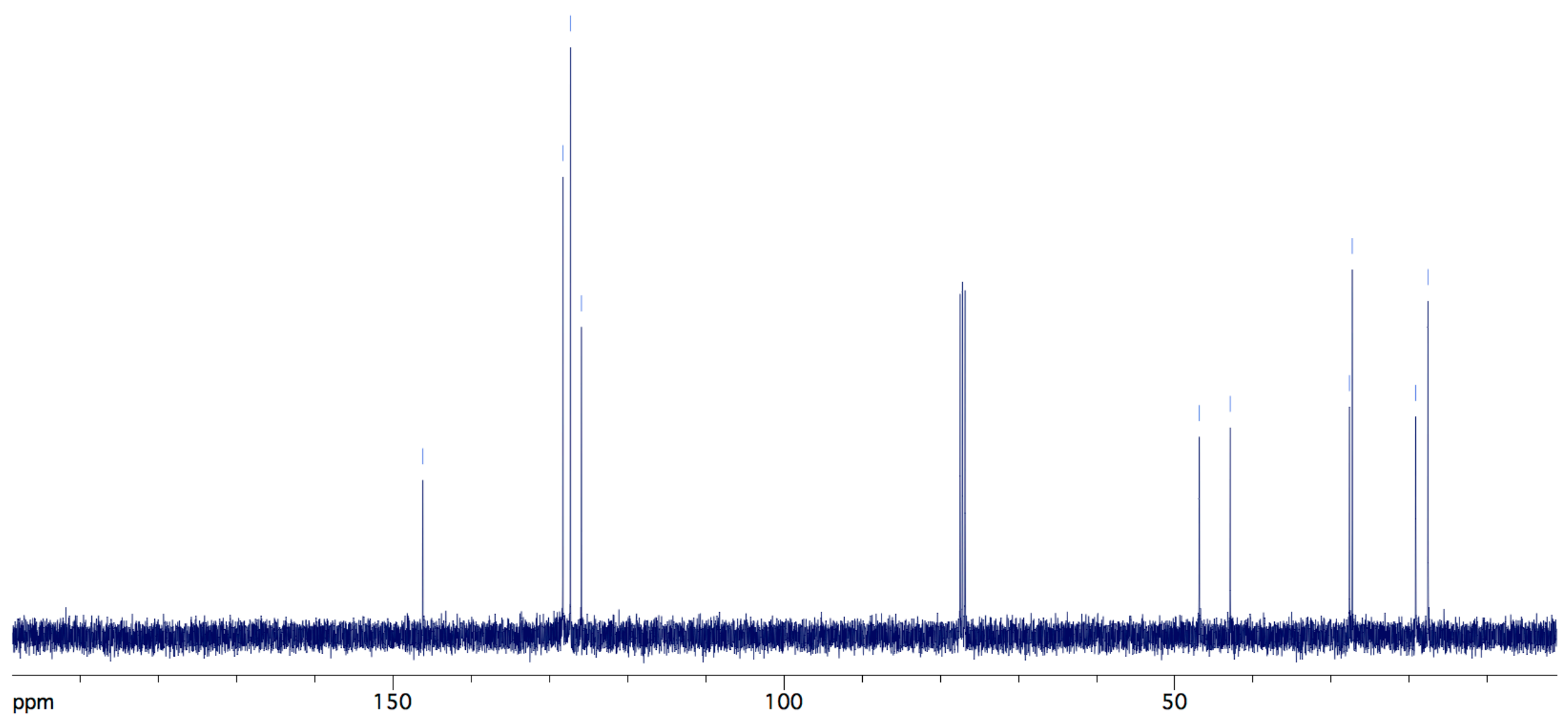




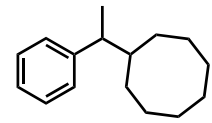

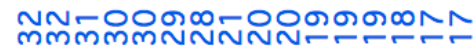

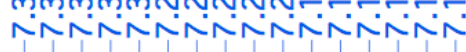

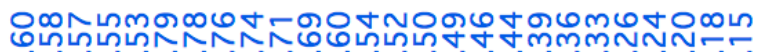

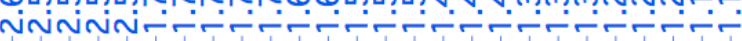
Lใน

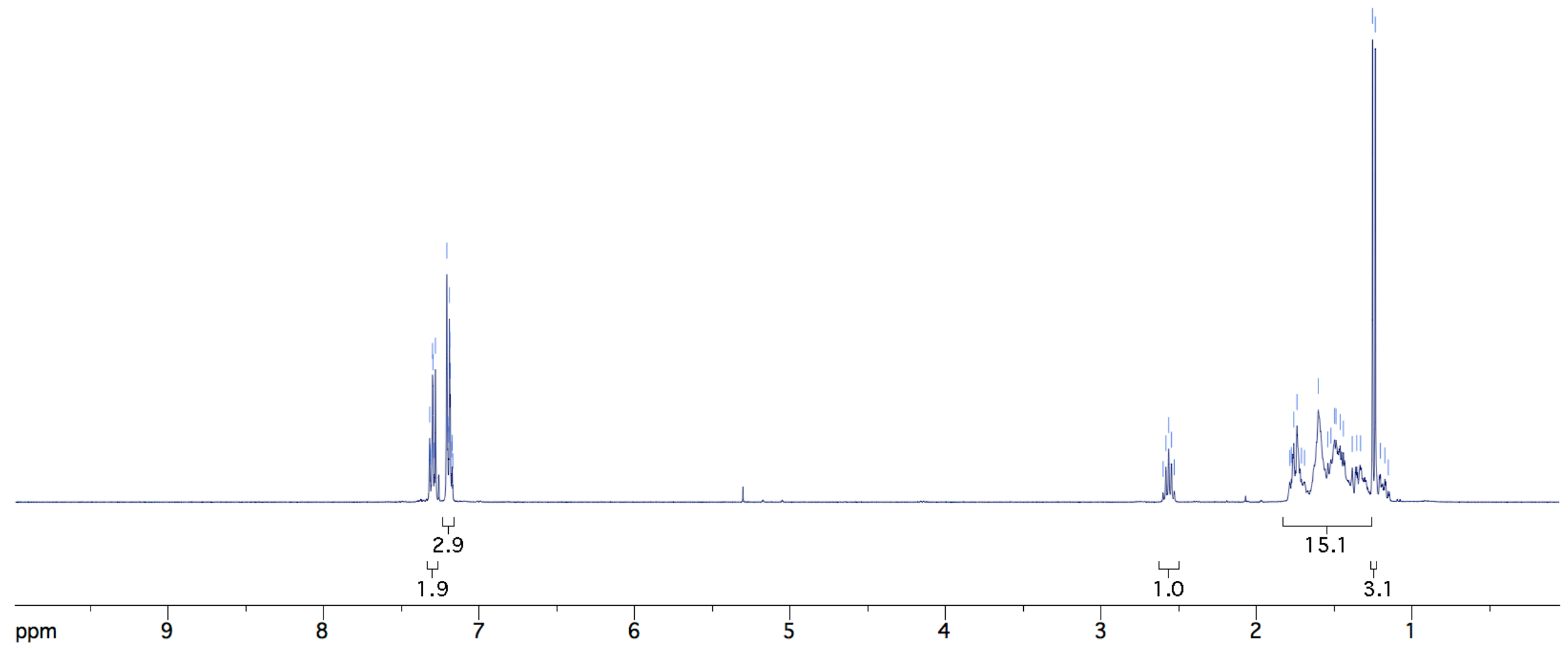



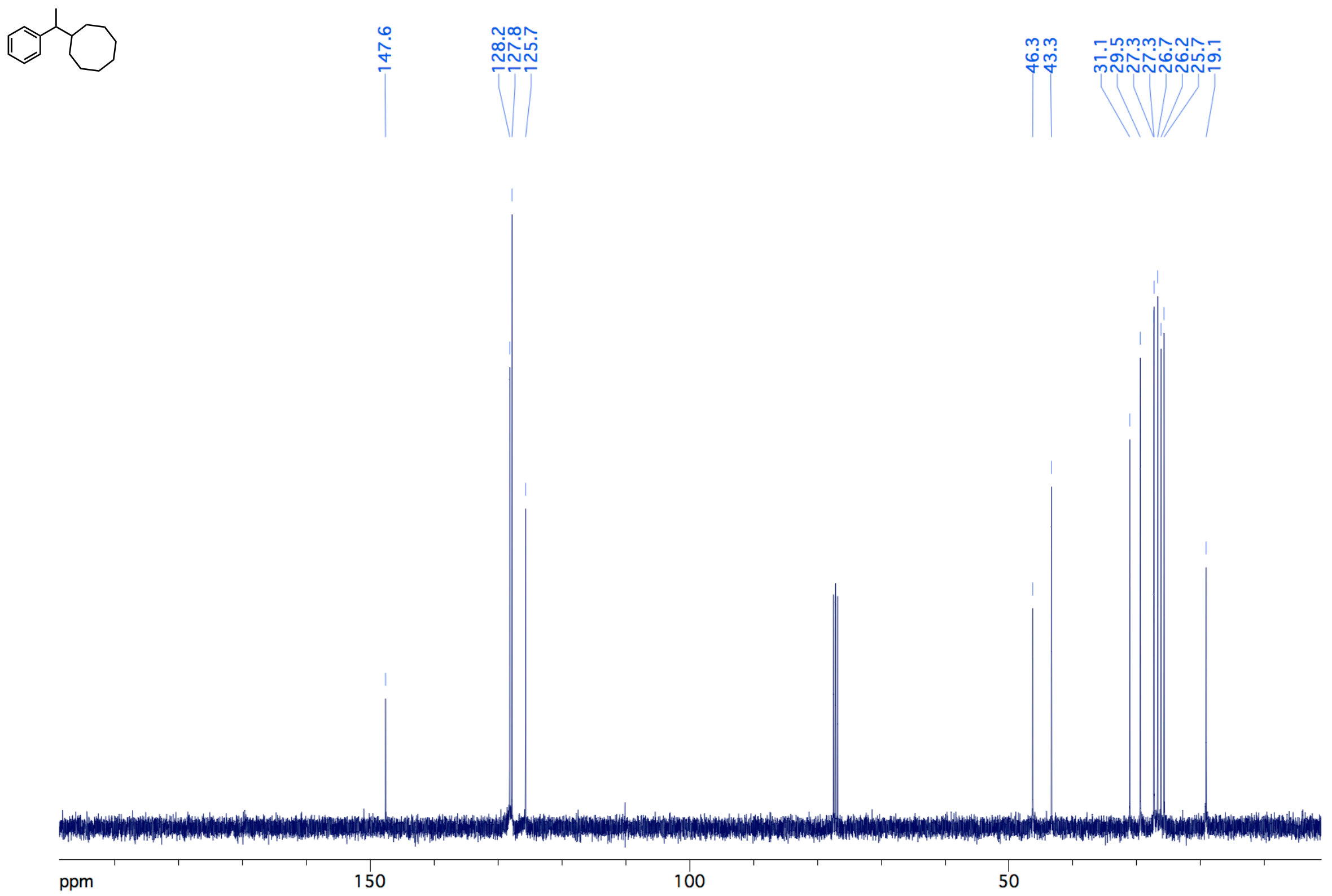


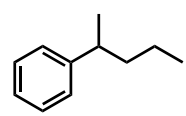

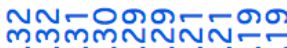

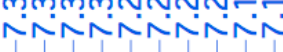

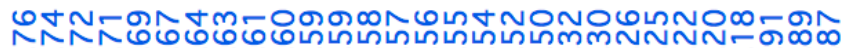

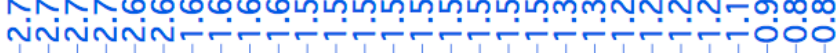
(l)

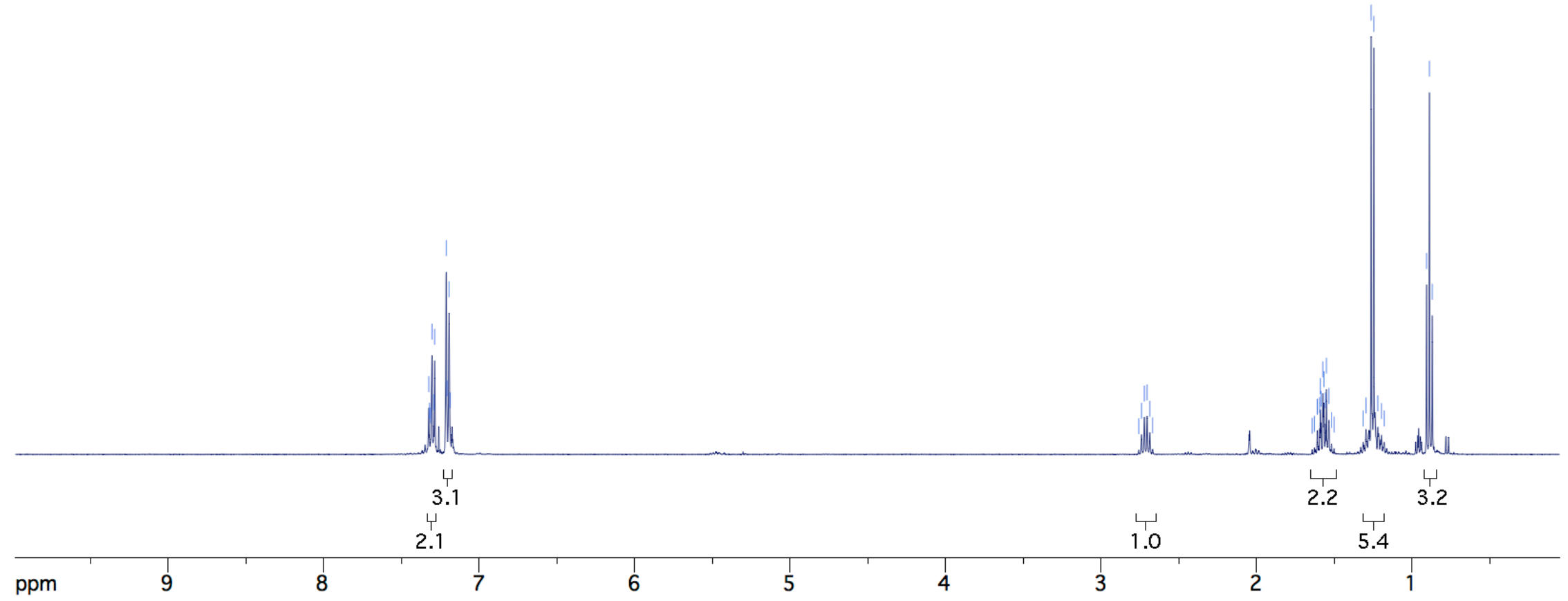



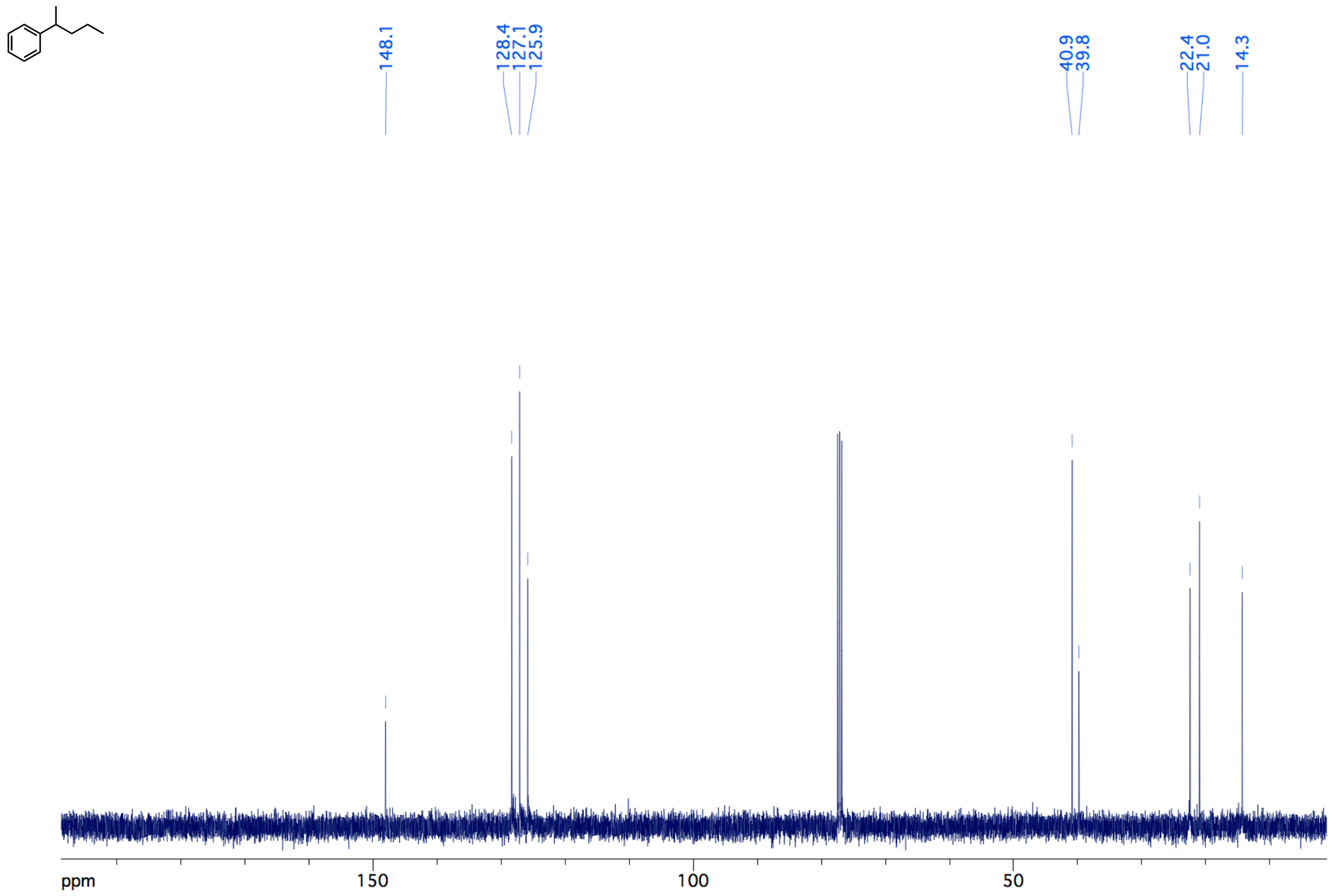


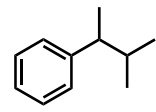

กิก-

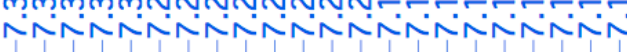

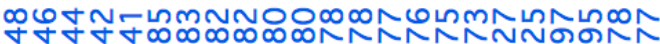

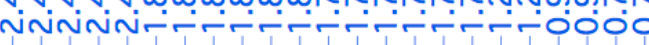

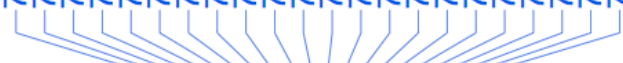

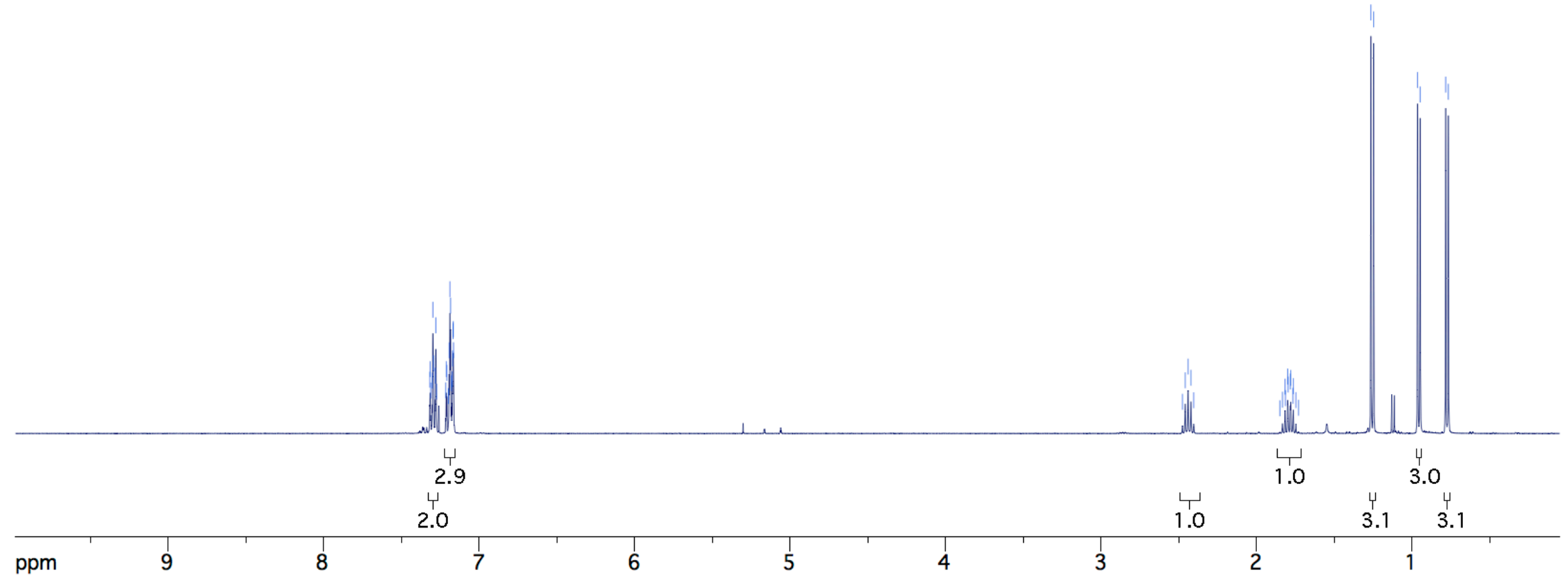



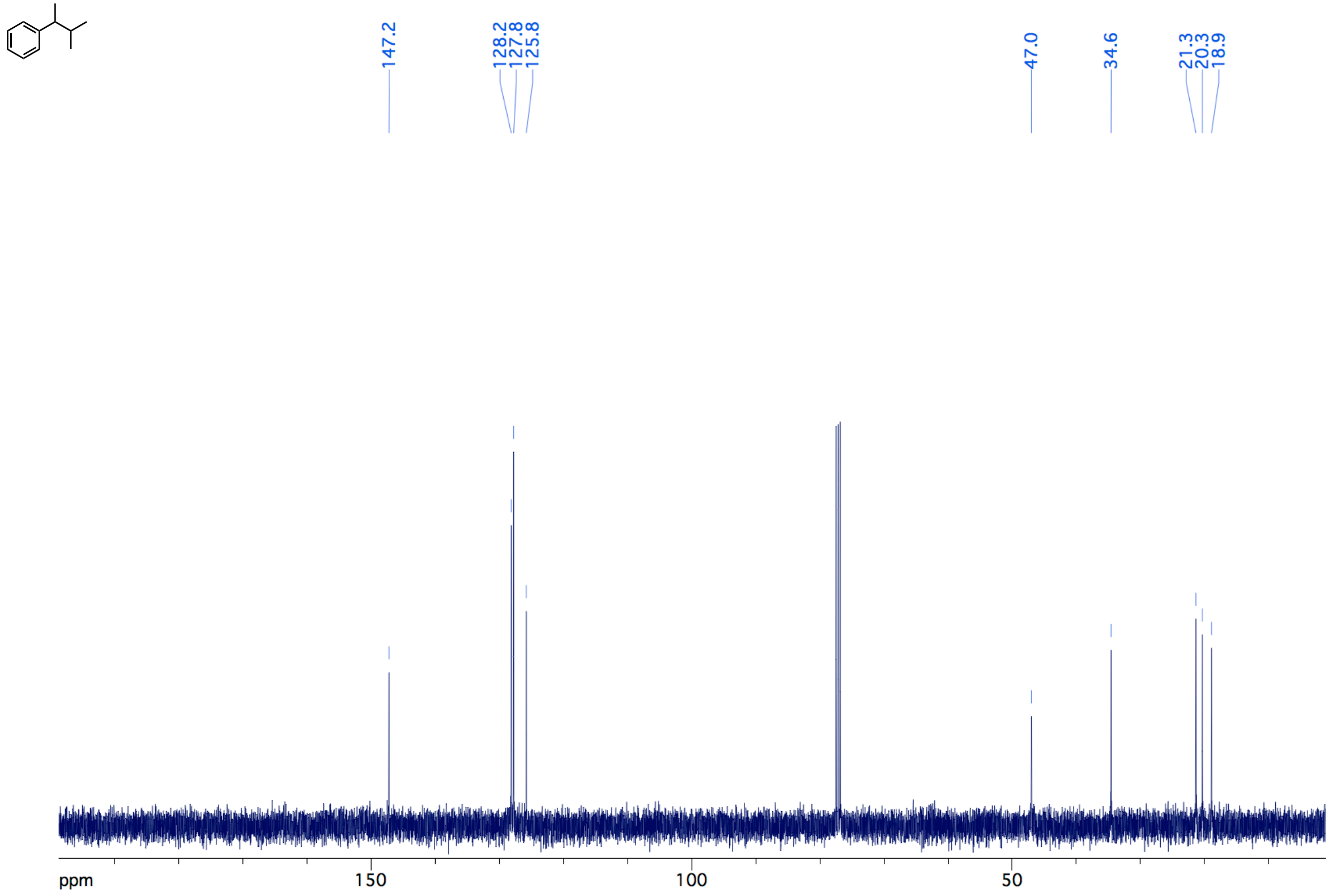


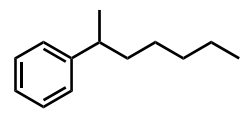

MMMNN-OONO minmmmmmñeñ

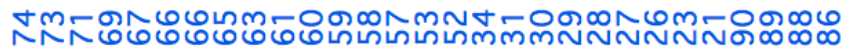

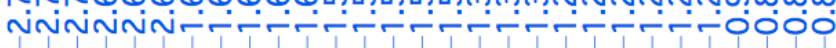

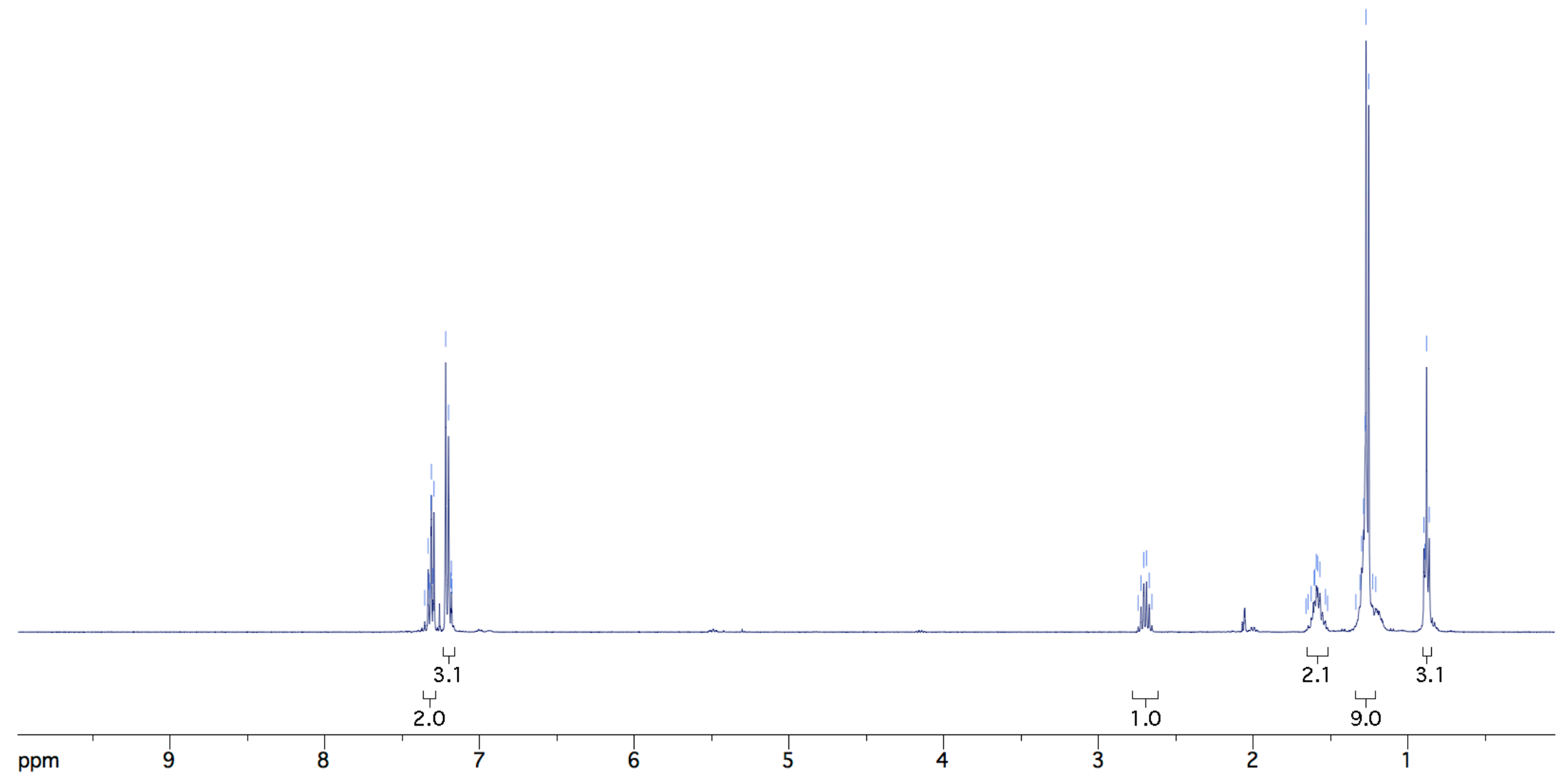



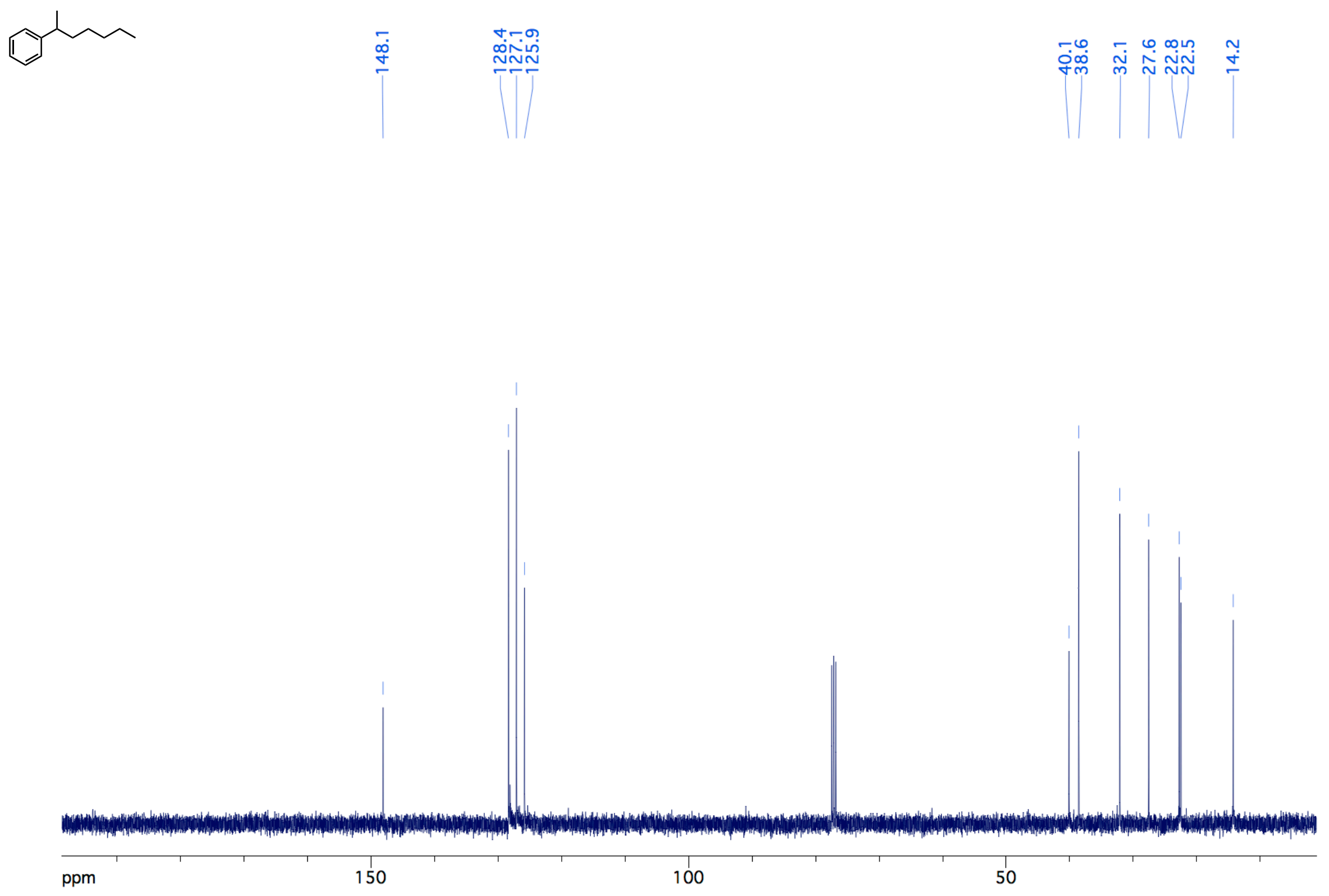
4-(sec-Butyl)-1,2-dichlorobenzene (28) ${ }^{1} \mathrm{H} \mathrm{NMR}\left(\mathrm{CDCl}_{3}, 600 \mathrm{MHz}\right)$
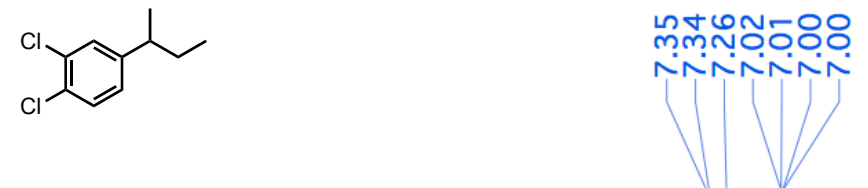

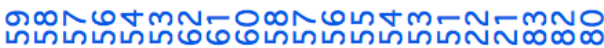

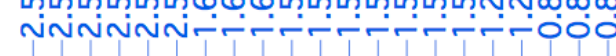

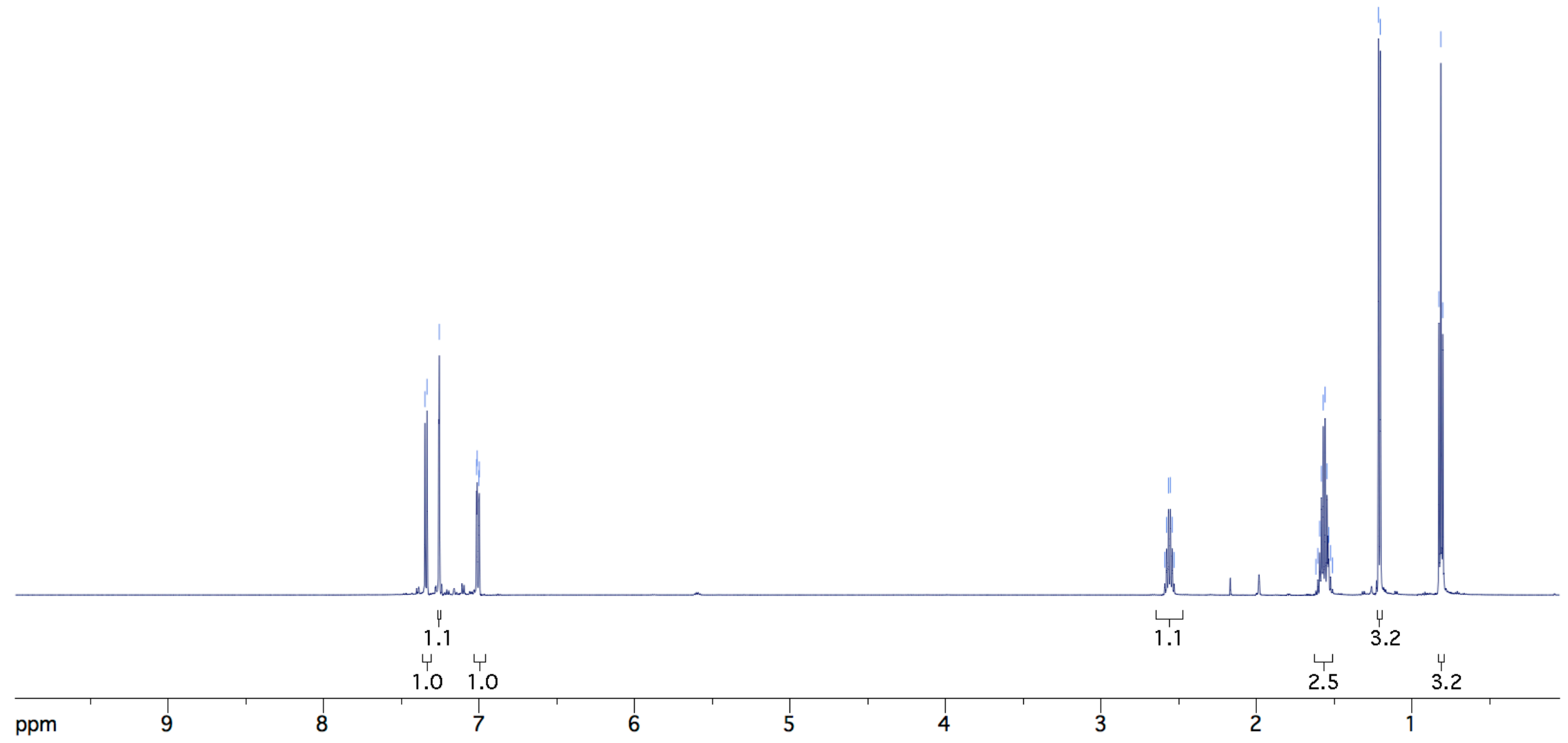



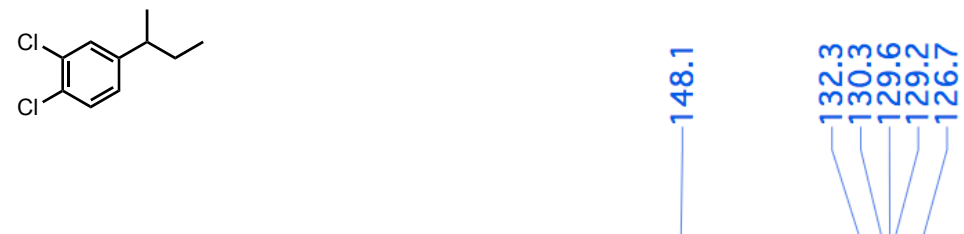

$$
\text { ๗ே }
$$

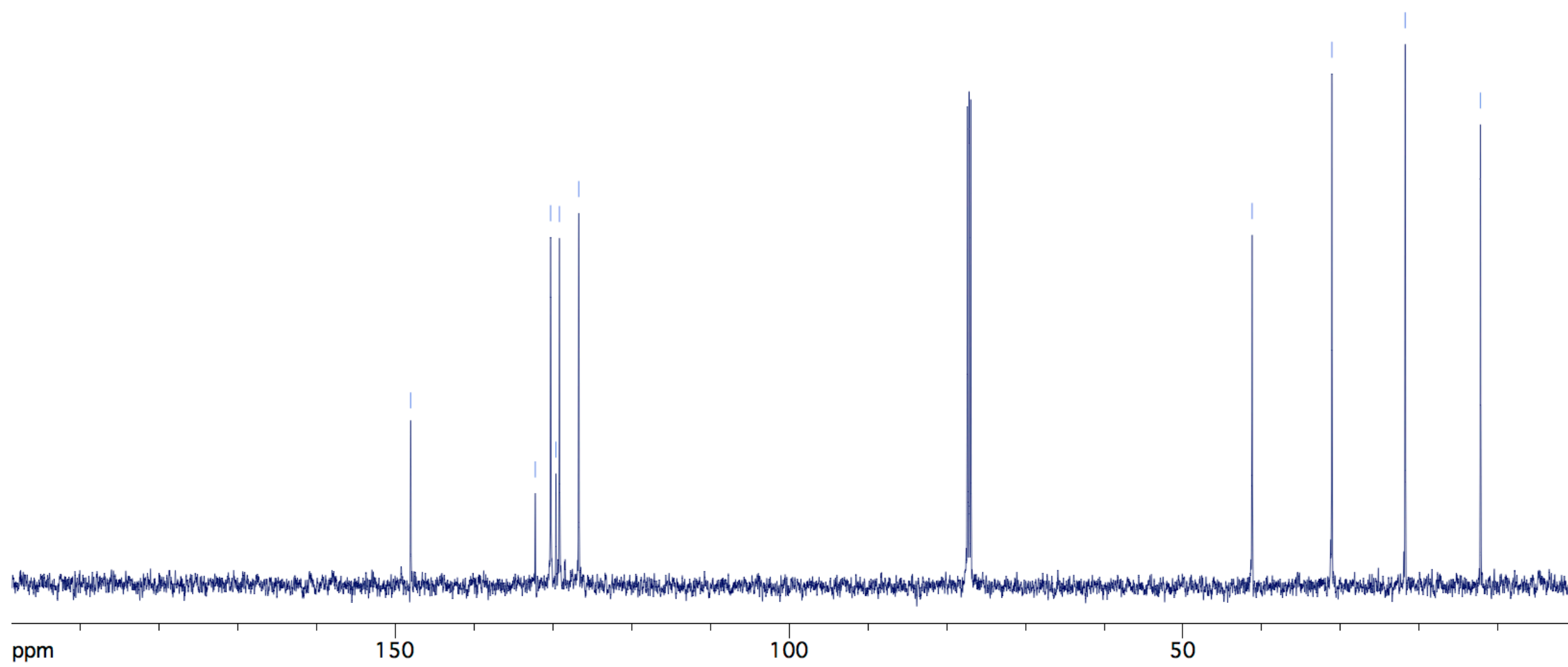


(1-Phenoxypropan-2-yl)benzene (29) ${ }^{1} \mathrm{H} \mathrm{NMR}\left(\mathrm{CDCl}_{3}, 600 \mathrm{MHz}\right)$
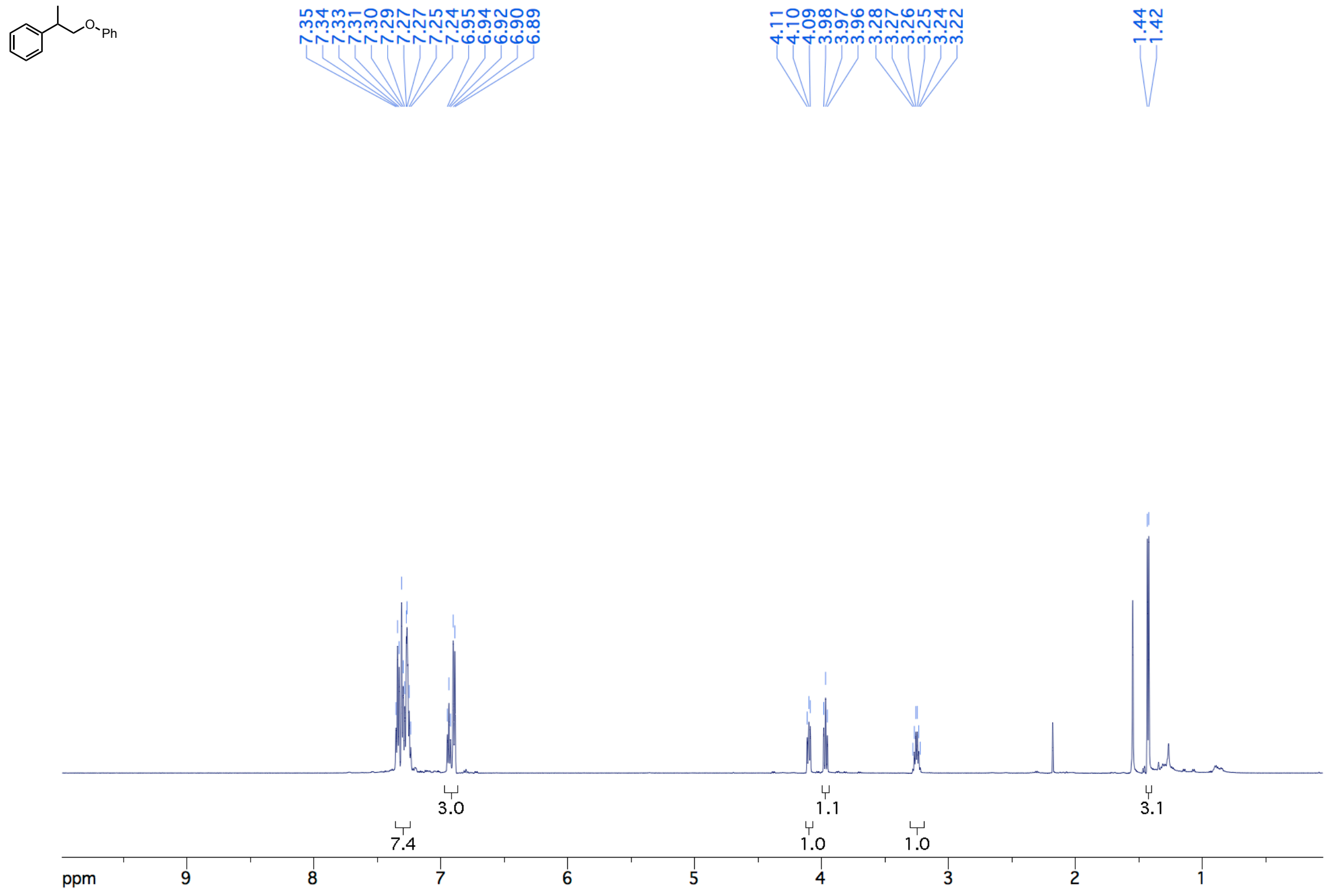
(1-Phenoxypropan-2-yl)benzene (29) ${ }^{13} \mathrm{C} \mathrm{NMR}\left(\mathrm{CDCl}_{3}, 151 \mathrm{MHz}\right)$

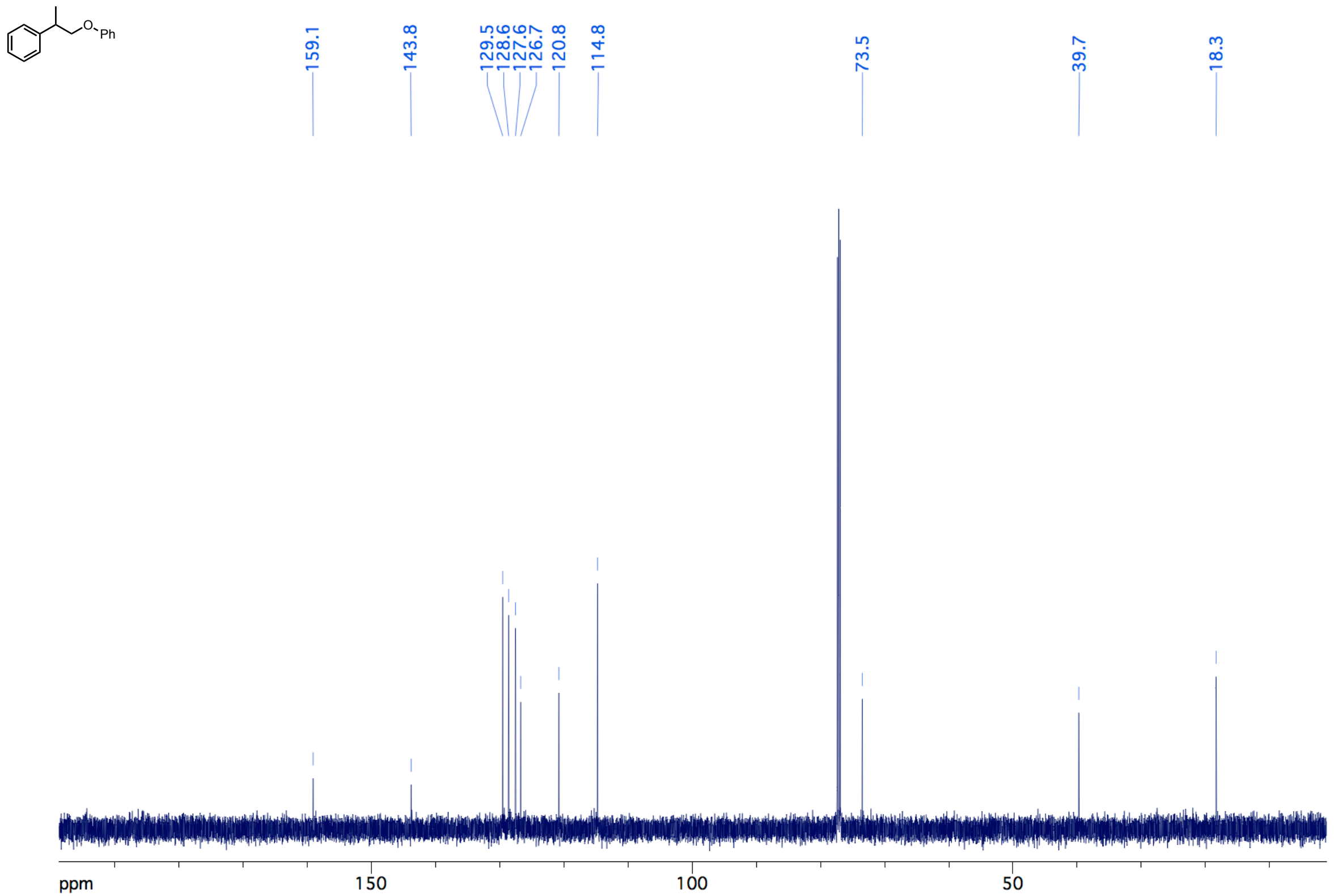


(1,1-Dimethoxypropane-1,2-diyl)dibenzene (30) ${ }^{1} \mathrm{H} \mathrm{NMR}\left(\mathrm{CDCl}_{3}, 600 \mathrm{MHz}\right)$
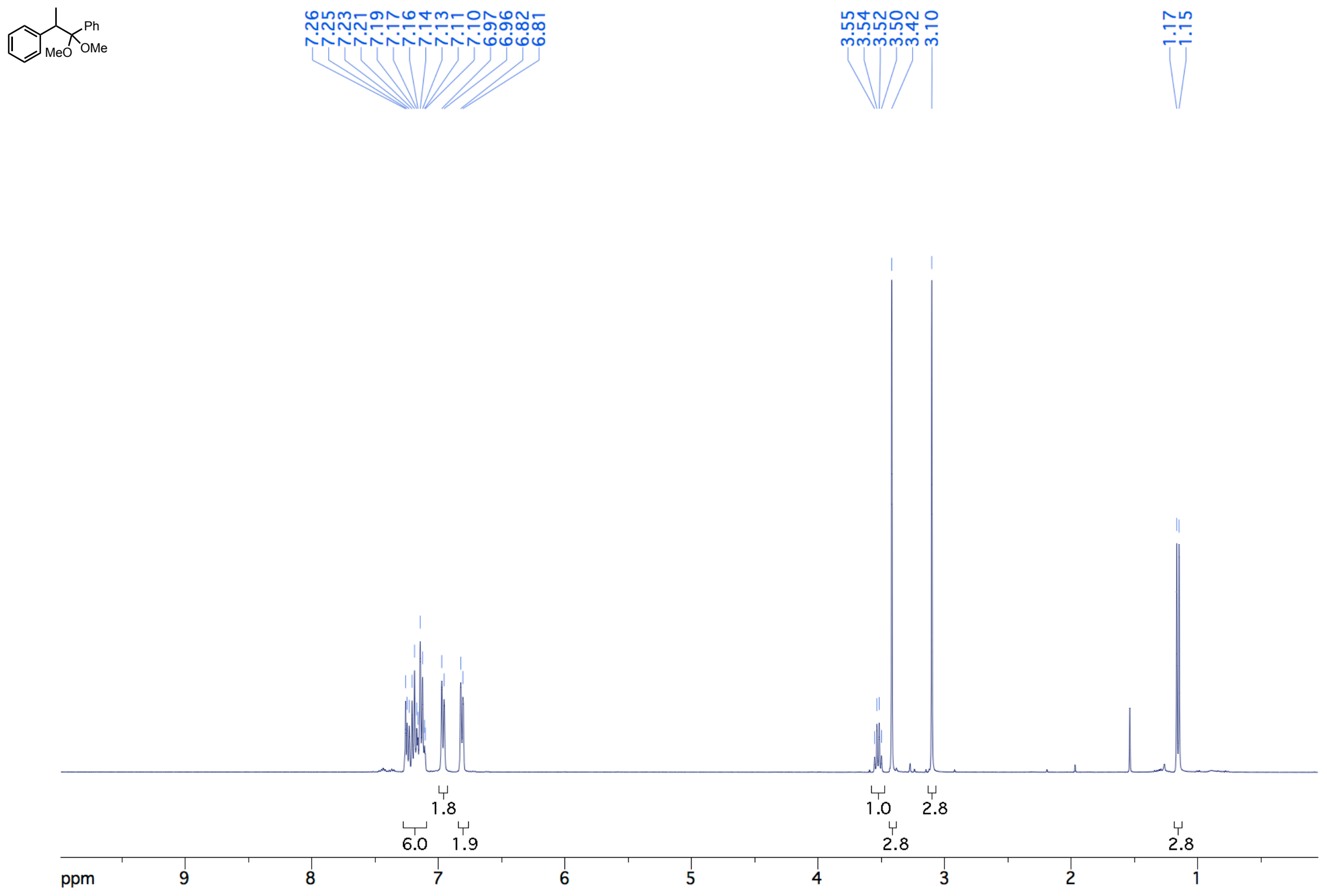
(1,1-Dimethoxypropane-1,2-diyl)dibenzene (30) ${ }^{13} \mathrm{C} \mathrm{NMR}\left(\mathrm{CDCl}_{3}, 151 \mathrm{MHz}\right)$
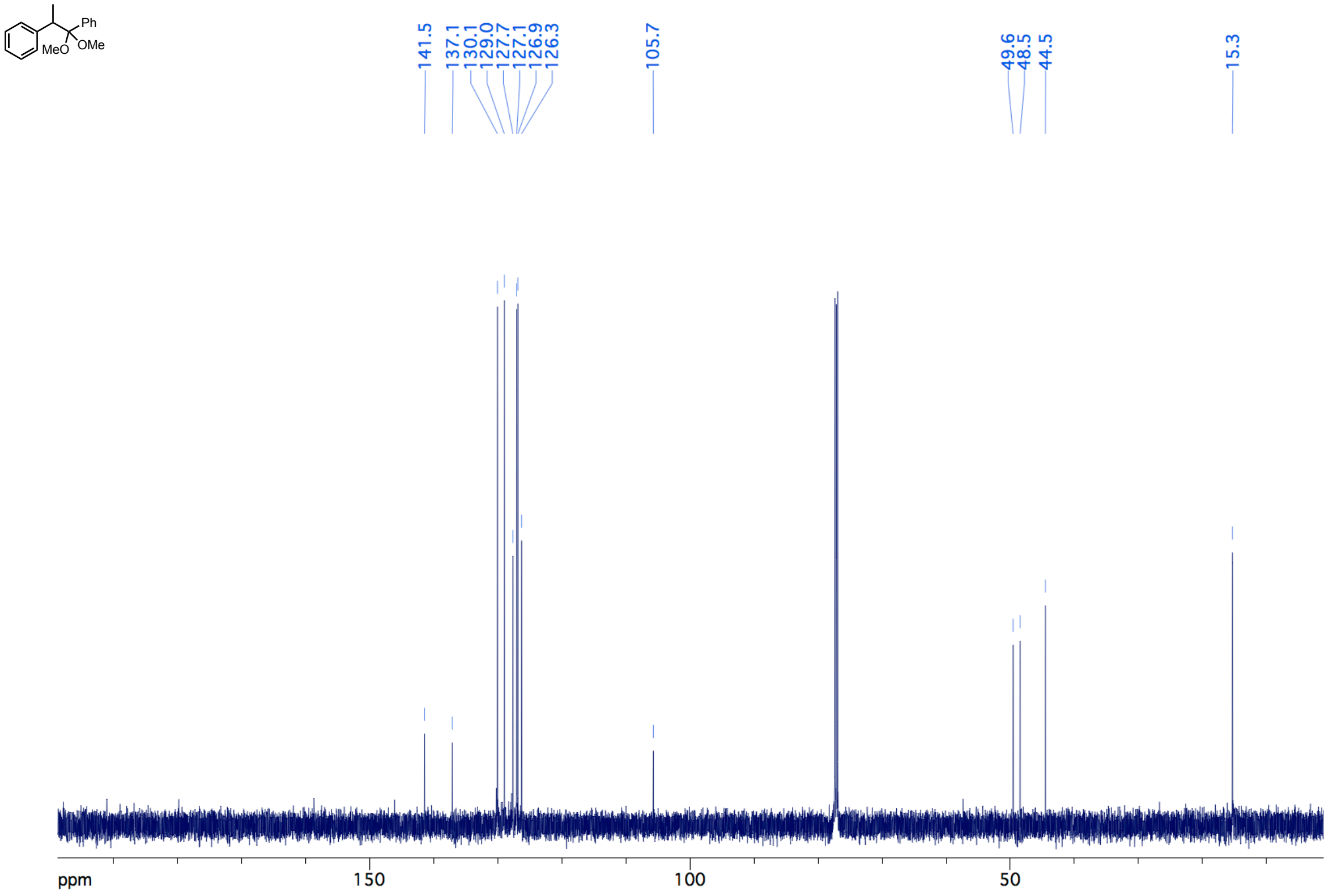


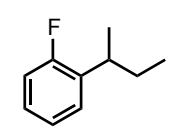

กุกา

ninisiniving

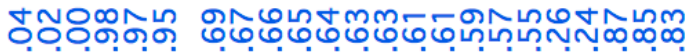
miminNN -

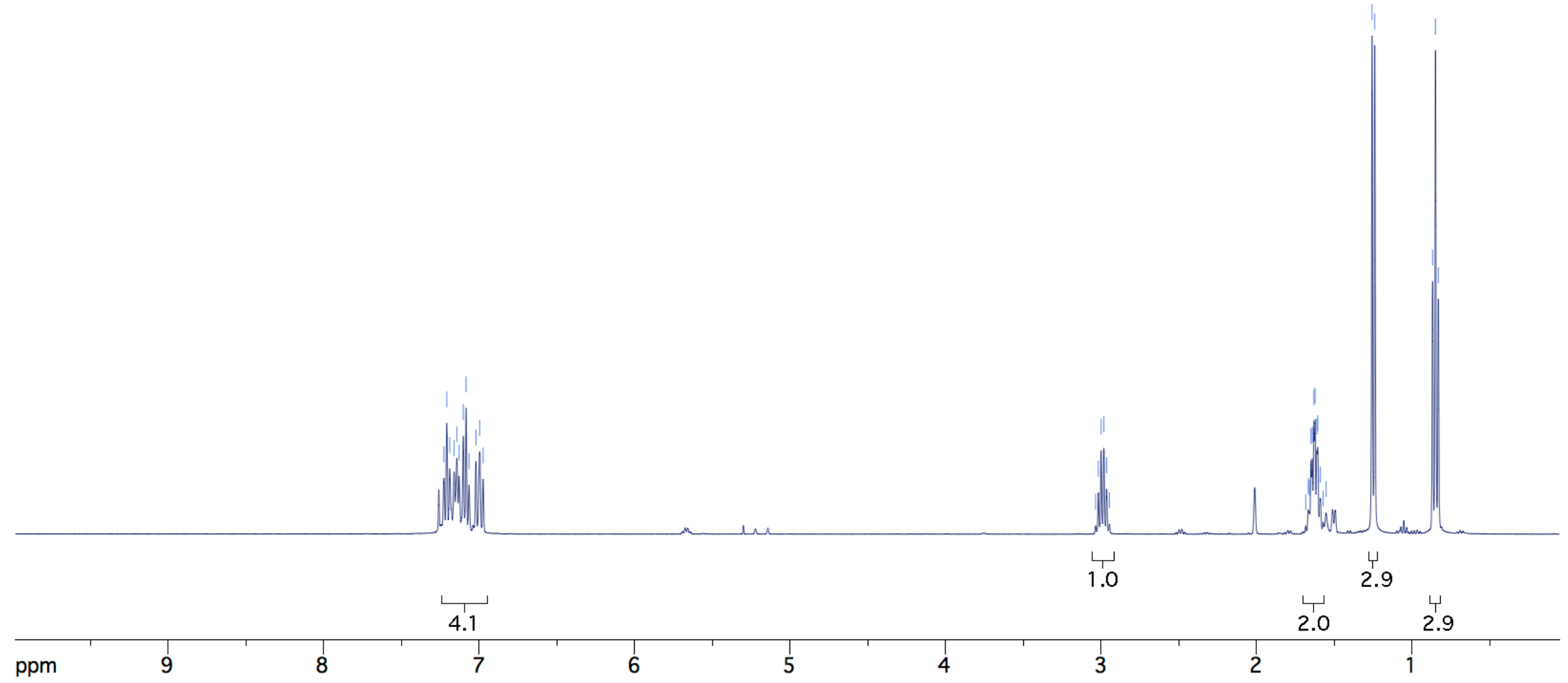



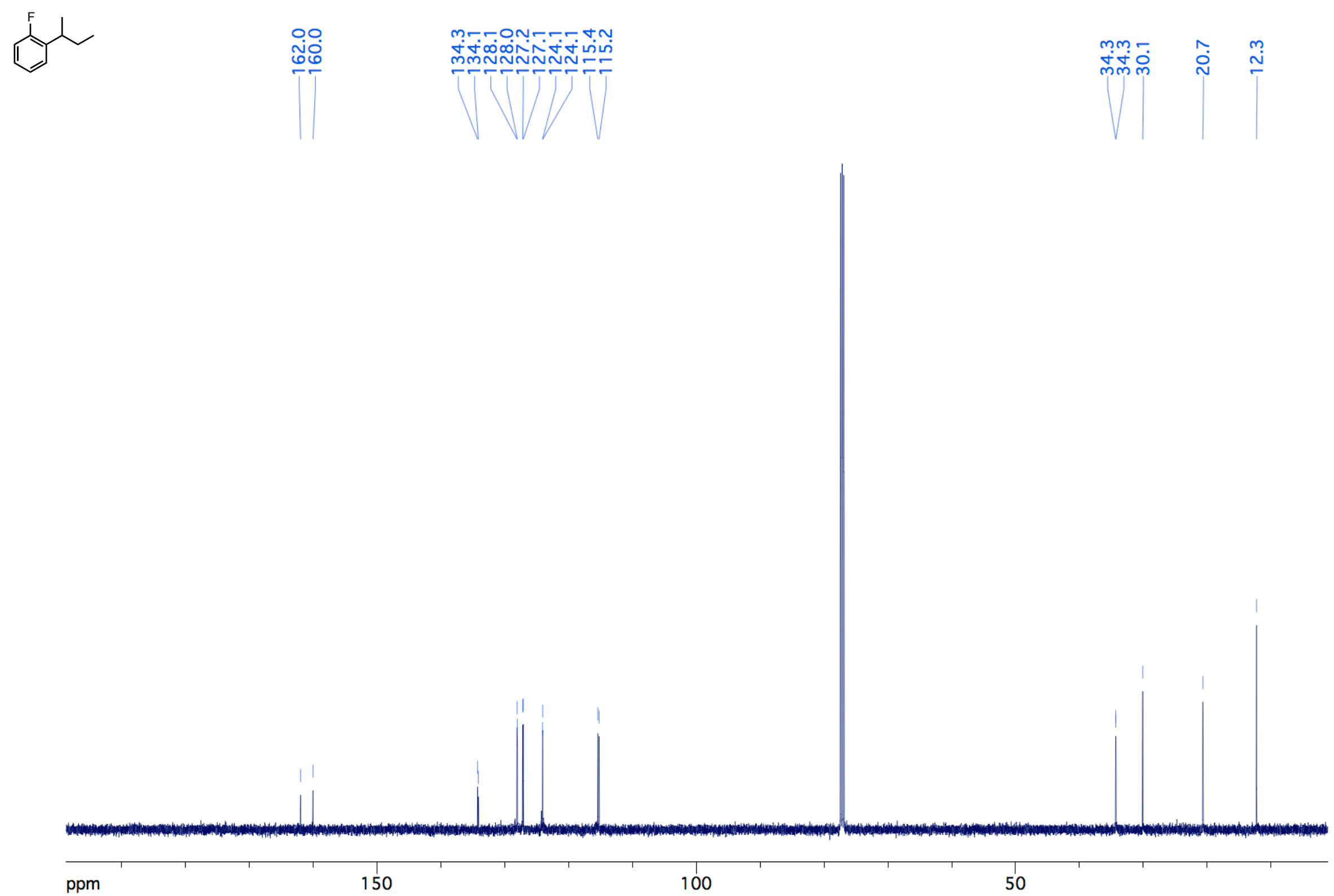

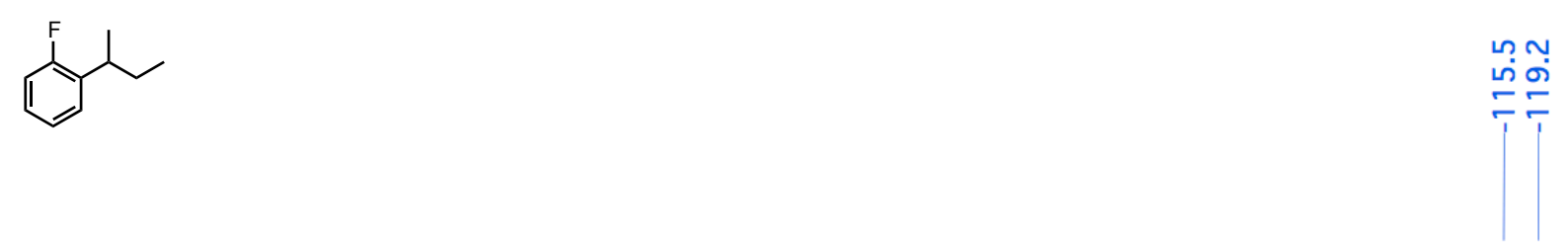

Starting material

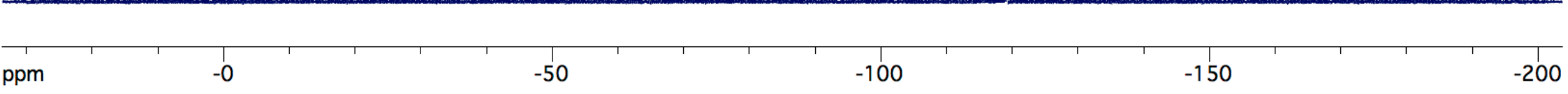


${ }^{1} \mathrm{H} \mathrm{NMR}\left(\mathrm{CDCl}_{3}, 600 \mathrm{MHz}\right)$

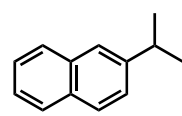

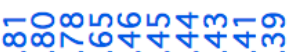

NiNiNiNiN

-

ตุฒn

minmin

U

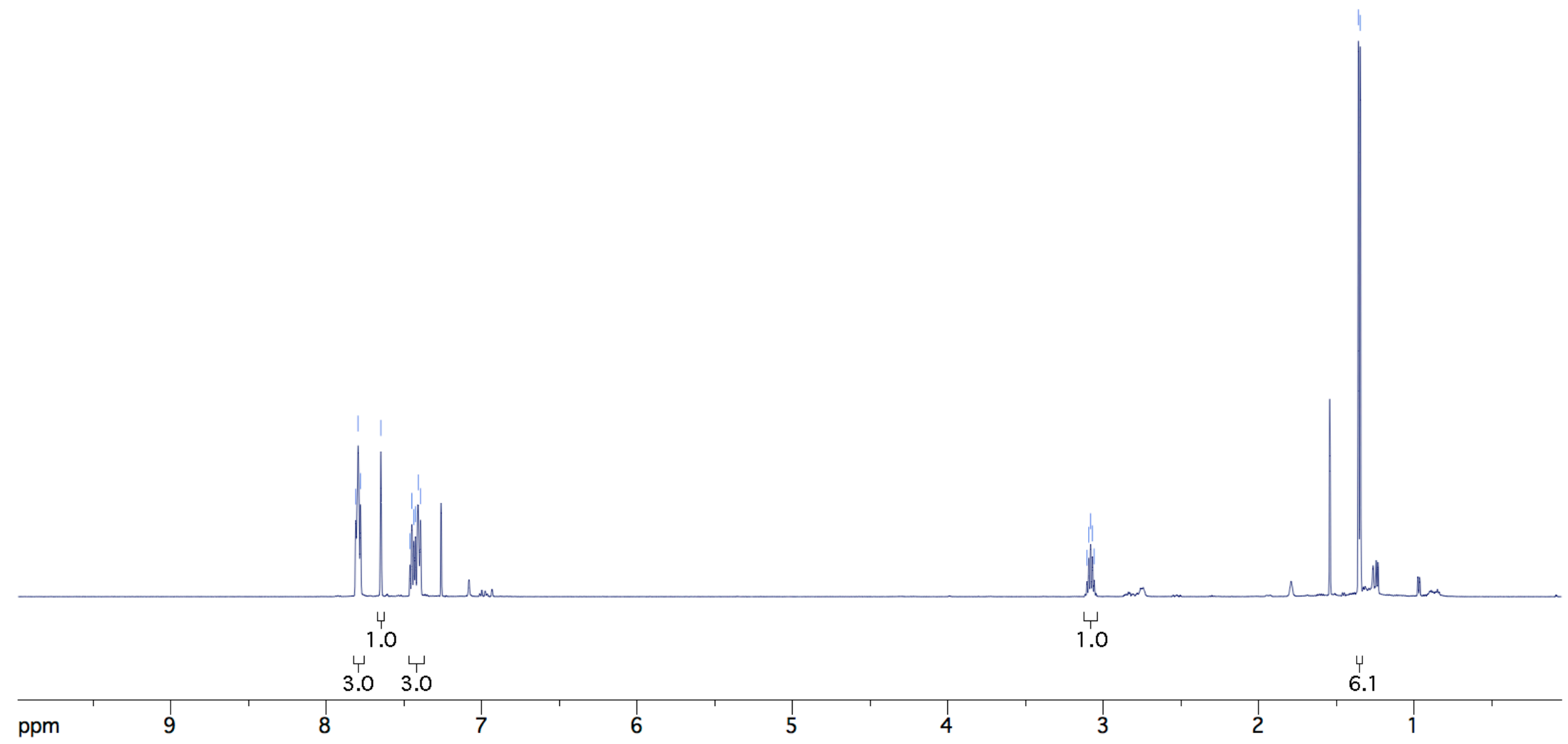



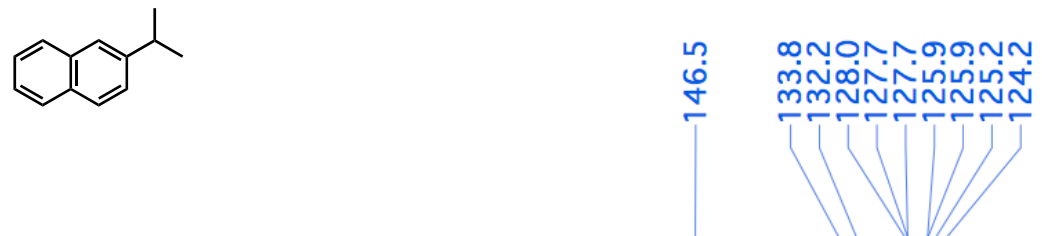

站 亲

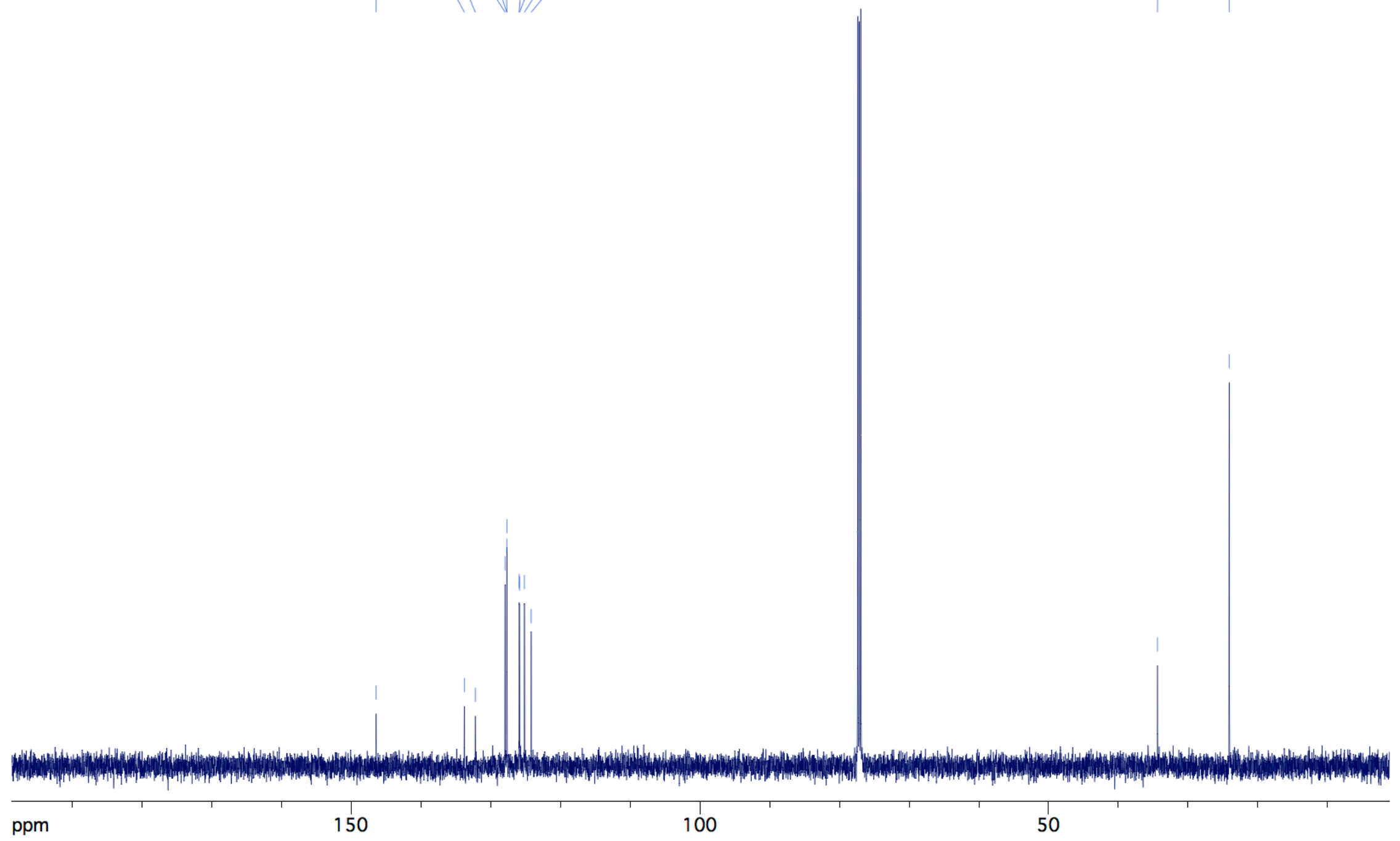


3-Ethyl-4'-methoxy-1,1'-biphenyl (33) ${ }^{1} \mathrm{H} \mathrm{NMR}\left(\mathrm{CDCl}_{3}, 400 \mathrm{MHz}\right)$

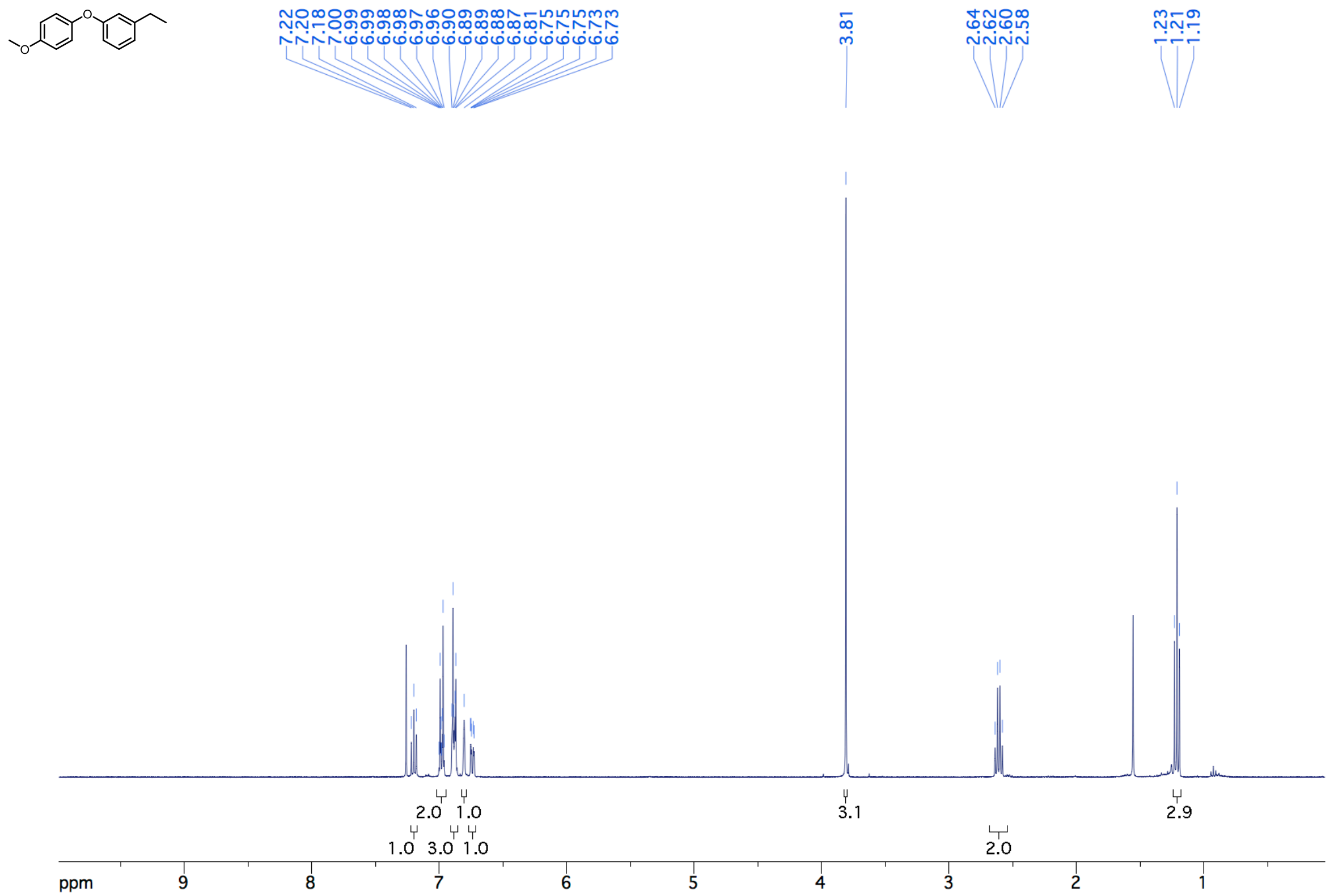




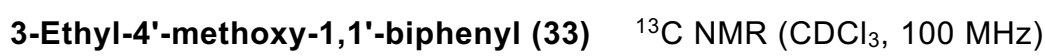

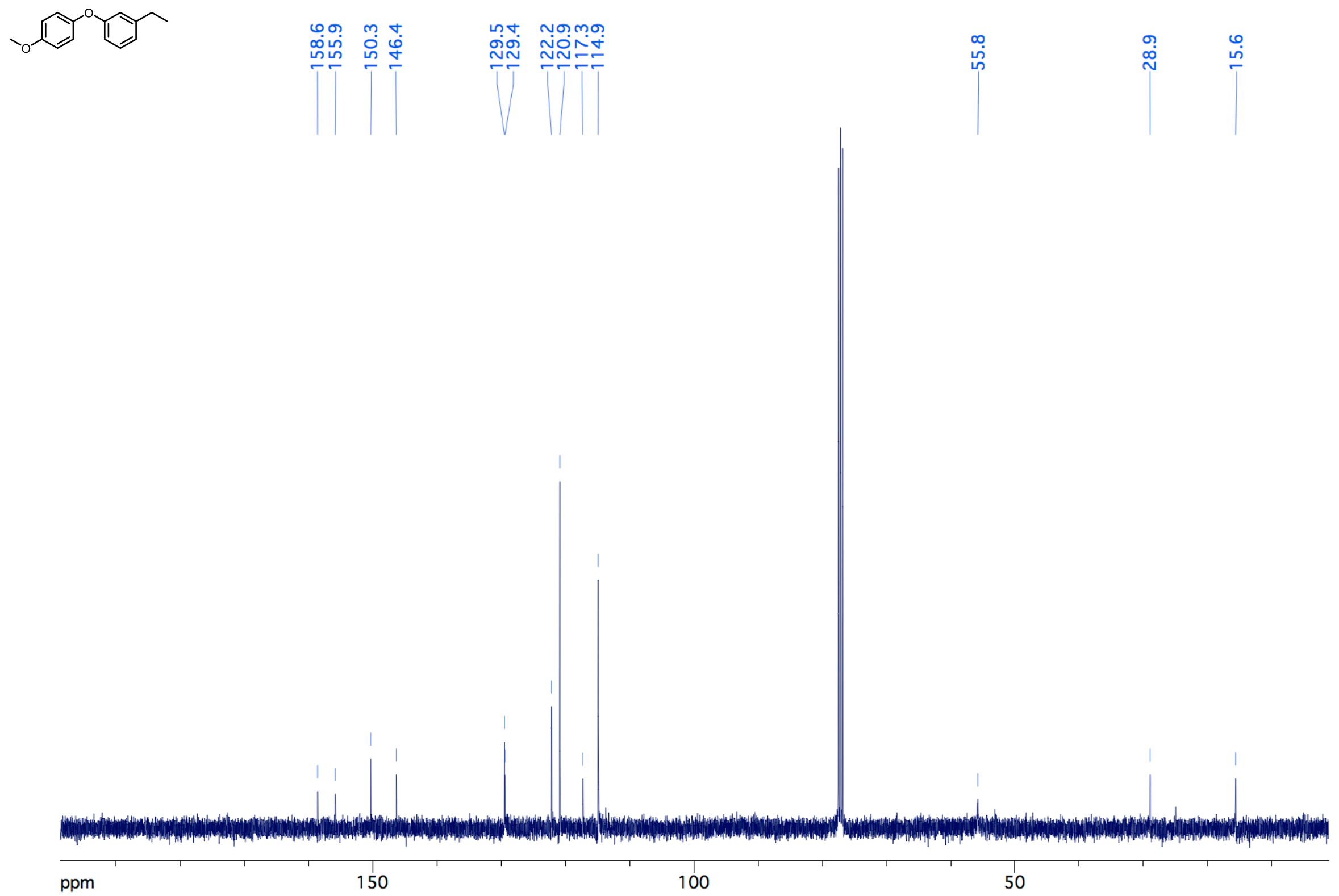


1-Ethoxy-4-ethylbenzene (34) ${ }^{1} \mathrm{H}$ NMR $\left(\mathrm{CDCl}_{3}, 400 \mathrm{MHz}\right)$

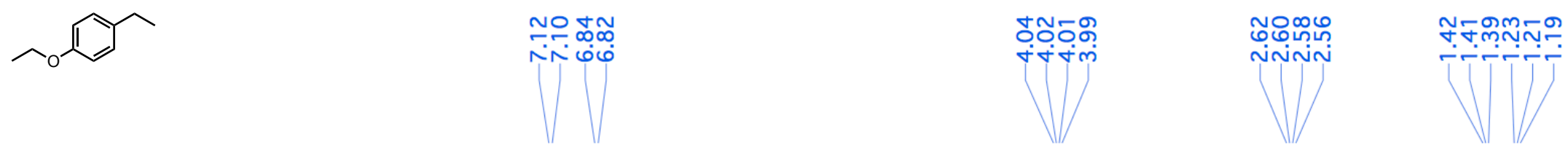

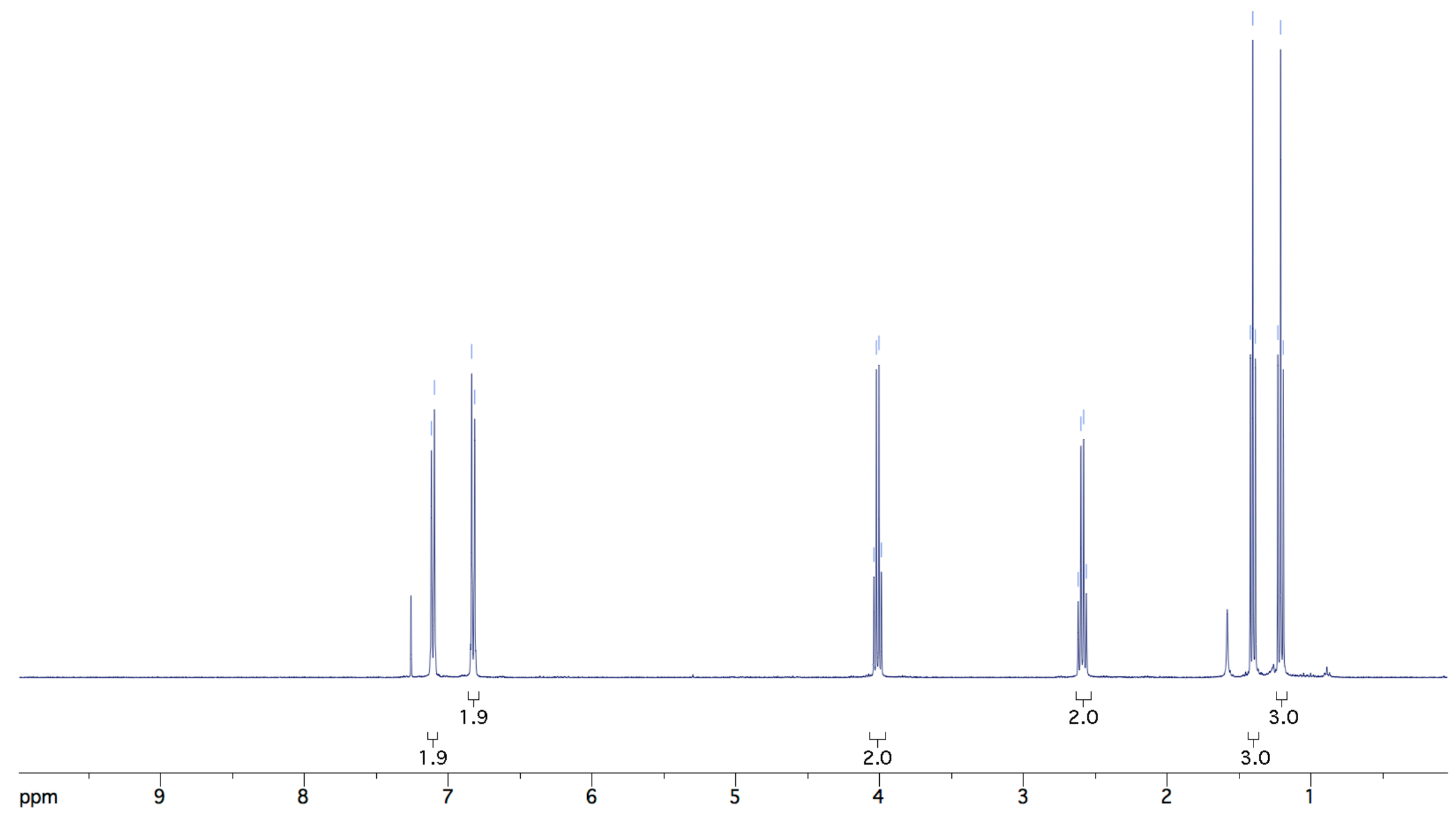


1-Ethoxy-4-ethylbenzene (34) ${ }^{13} \mathrm{C} \mathrm{NMR}\left(\mathrm{CDCl}_{3}, 100 \mathrm{MHz}\right)$
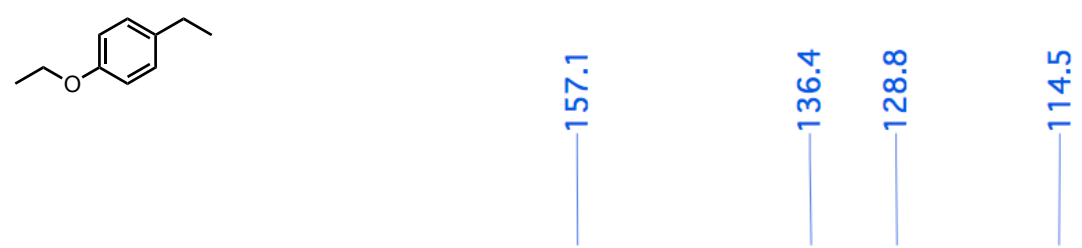

i

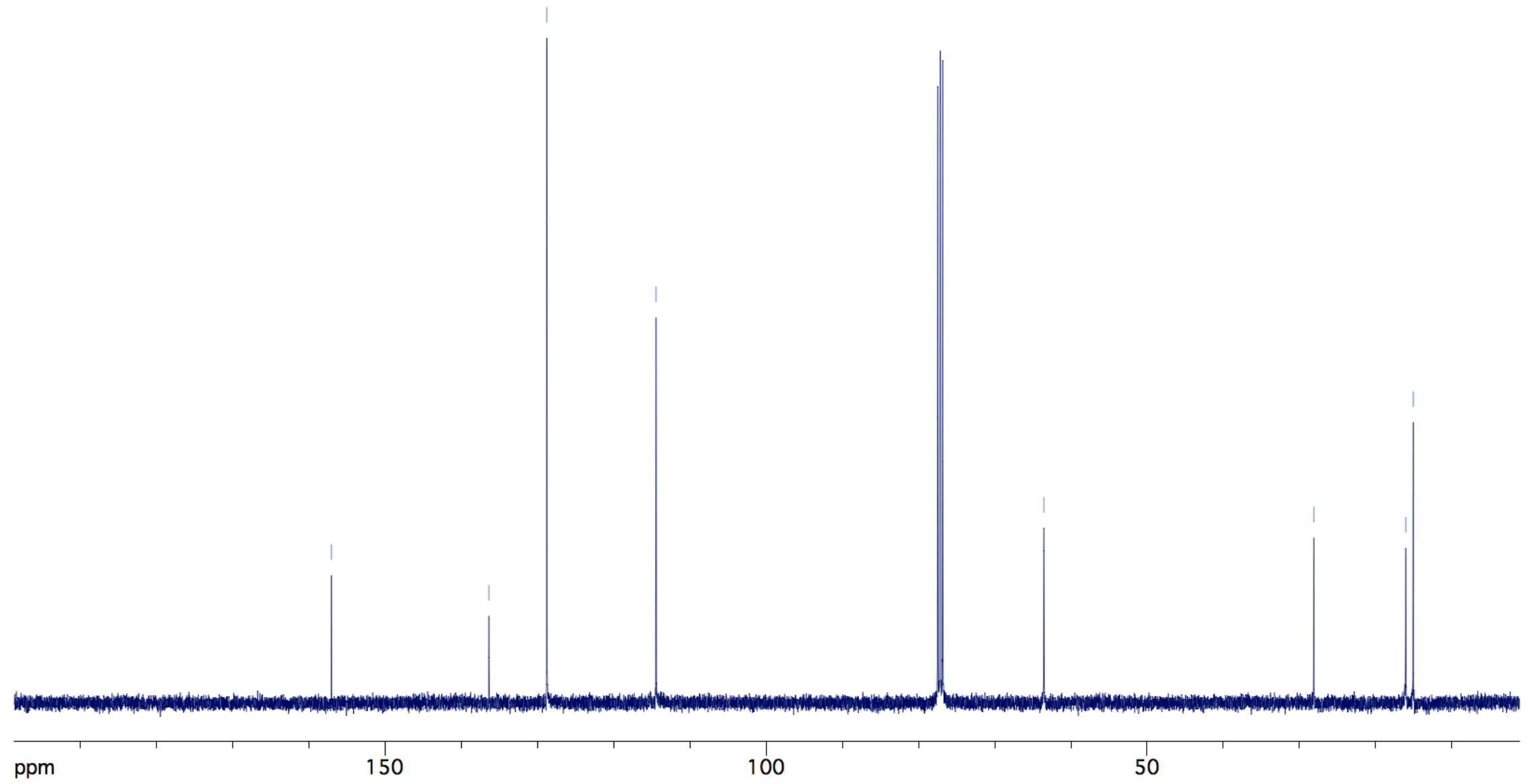


1,2-diphenylethane (35) ${ }^{1} \mathrm{H} \mathrm{NMR}\left(\mathrm{CDCl}_{3}, 400 \mathrm{MHz}\right)$
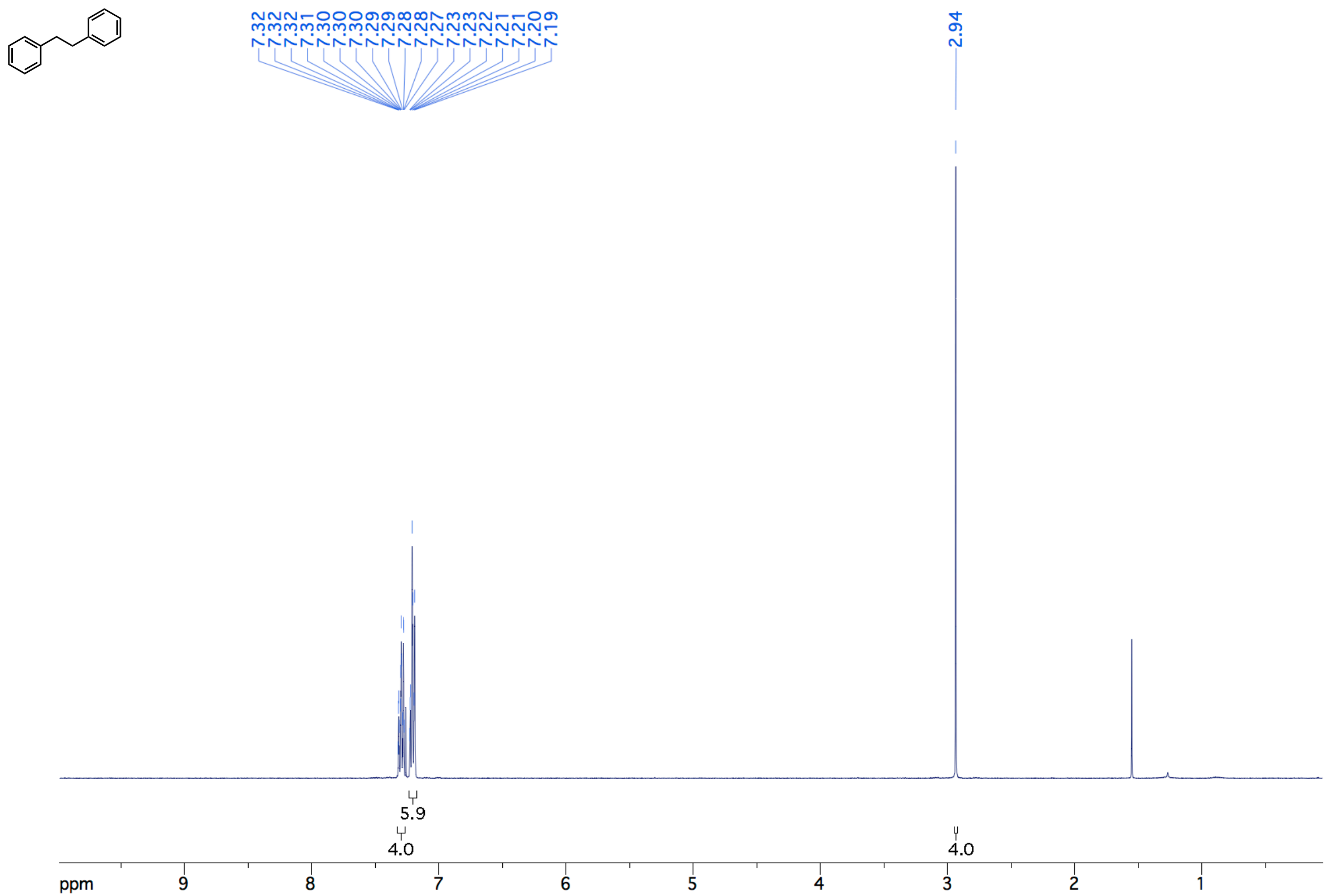

174 
1,2-diphenylethane $(35){ }^{13} \mathrm{C} \mathrm{NMR}\left(\mathrm{CDCl}_{3}, 100 \mathrm{MHz}\right)$
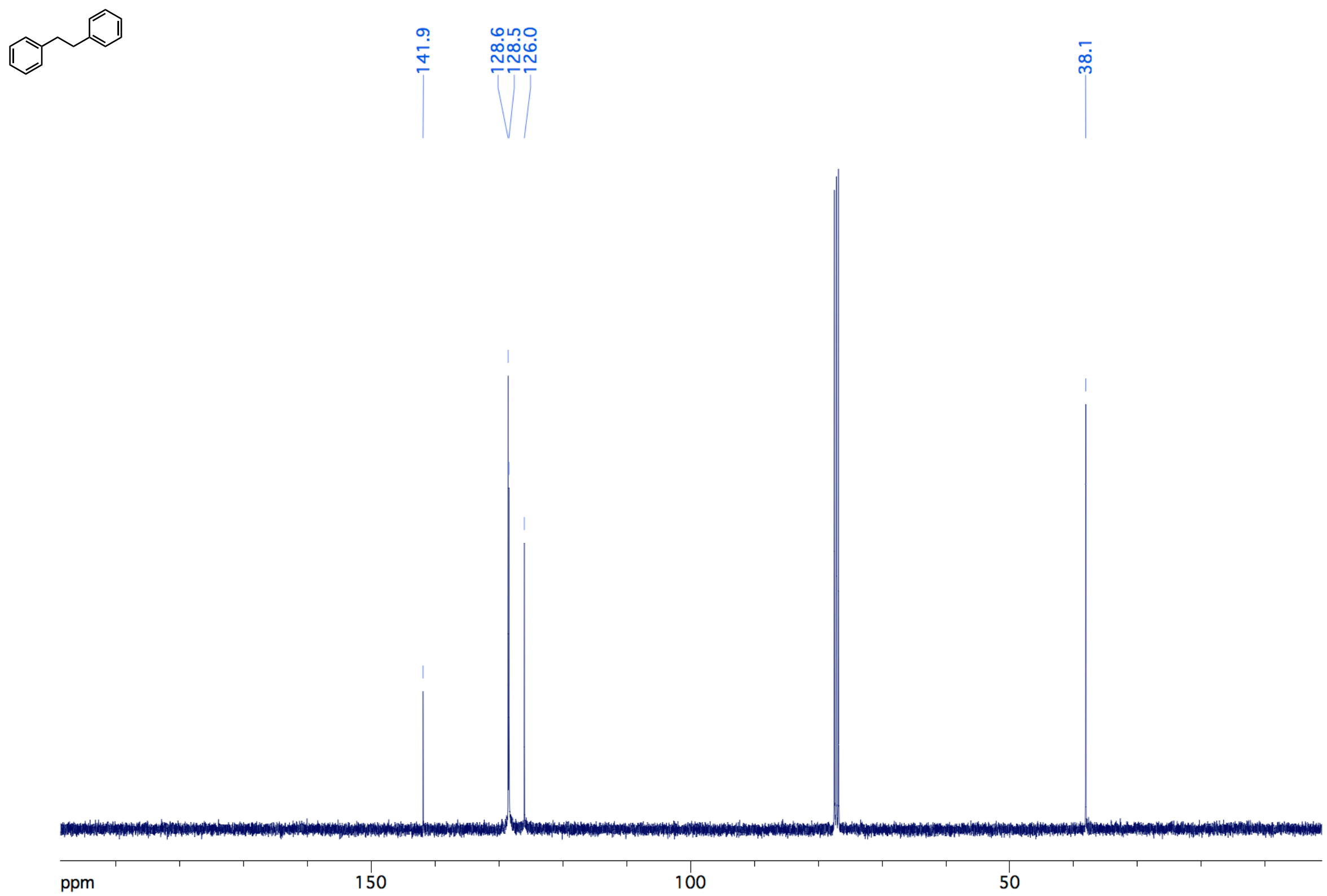

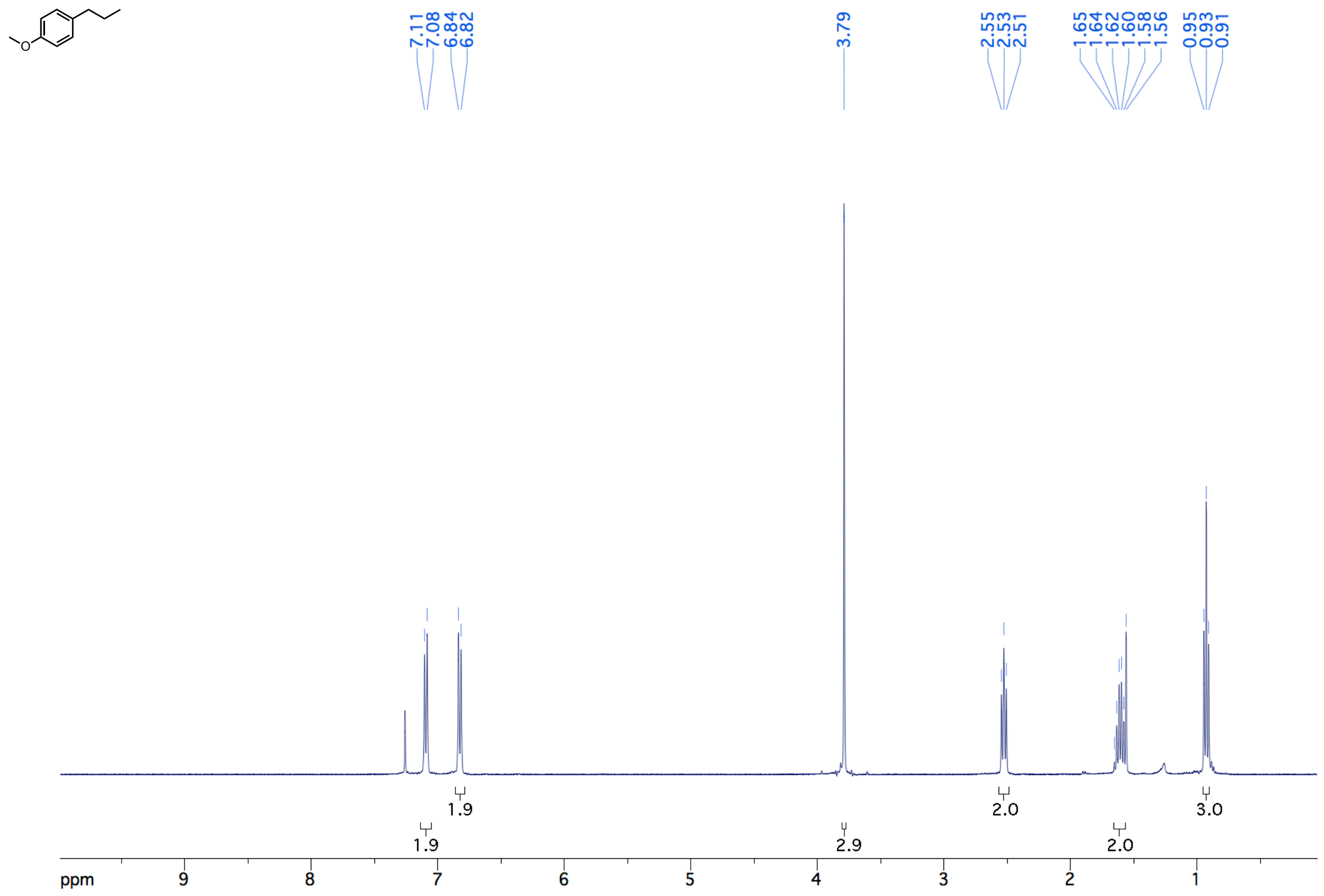

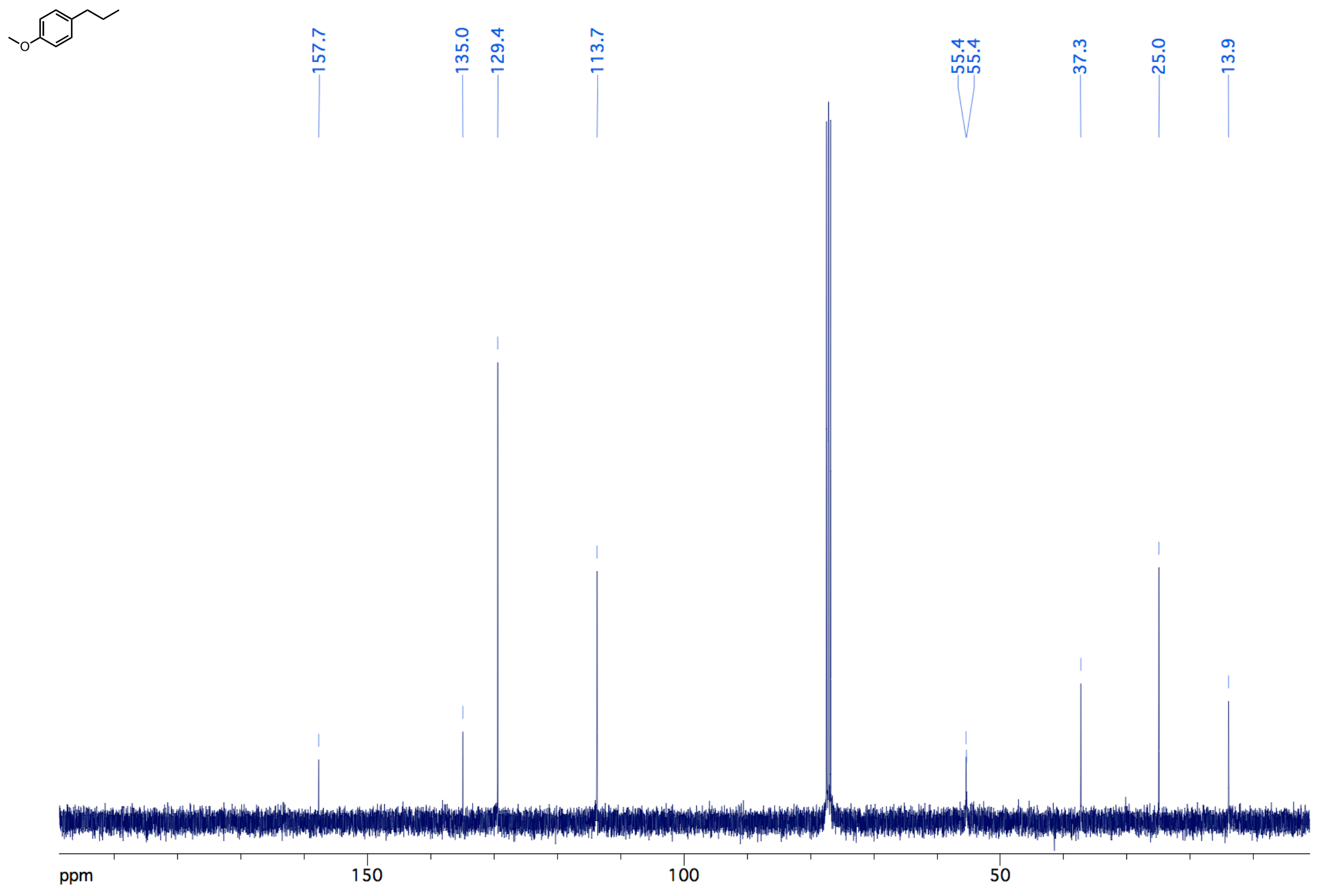

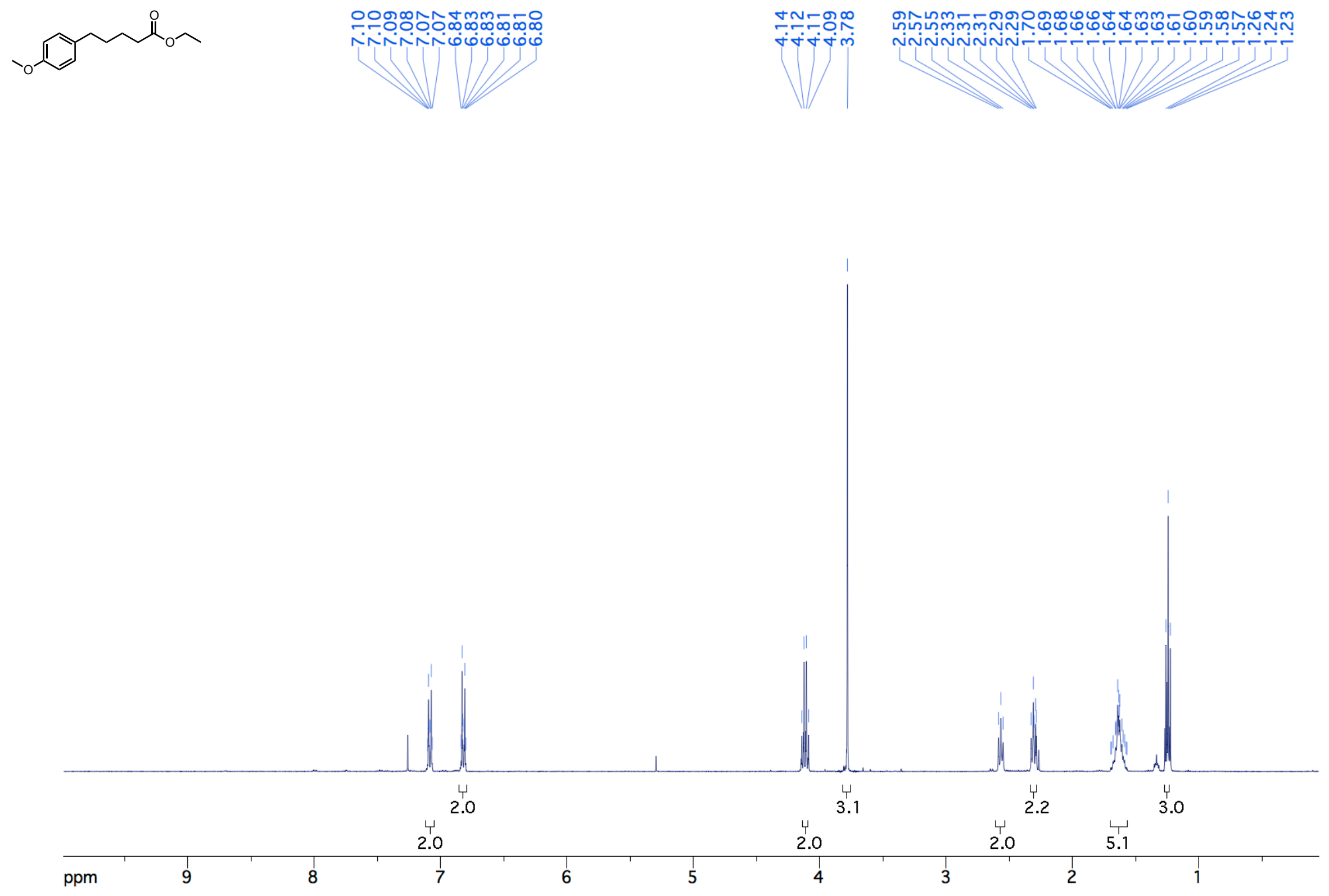

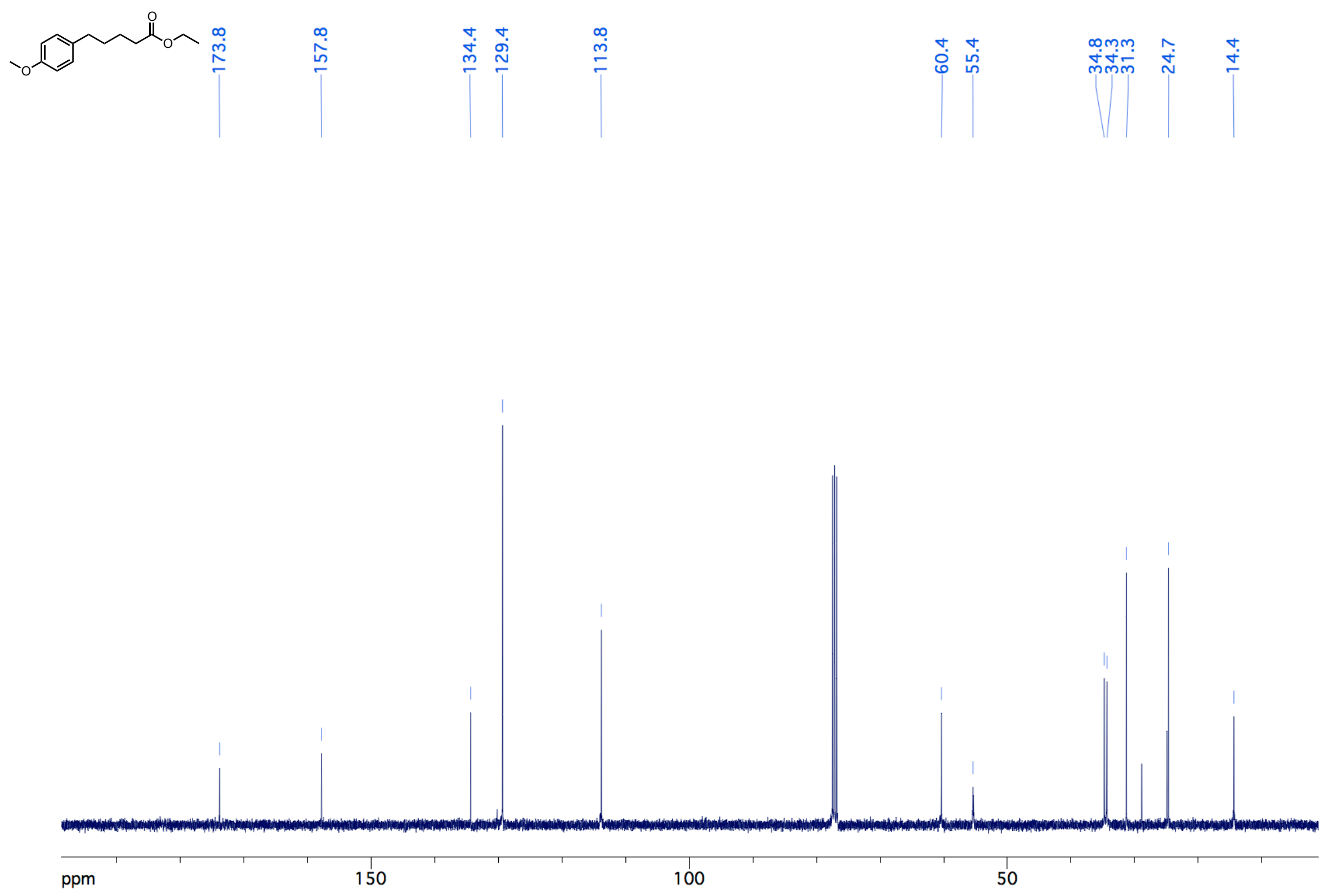
1-Butyl-4-methoxybenzene (38) ${ }^{1} \mathrm{H}$ NMR $\left(\mathrm{CDCl}_{3}, 400 \mathrm{MHz}\right)$
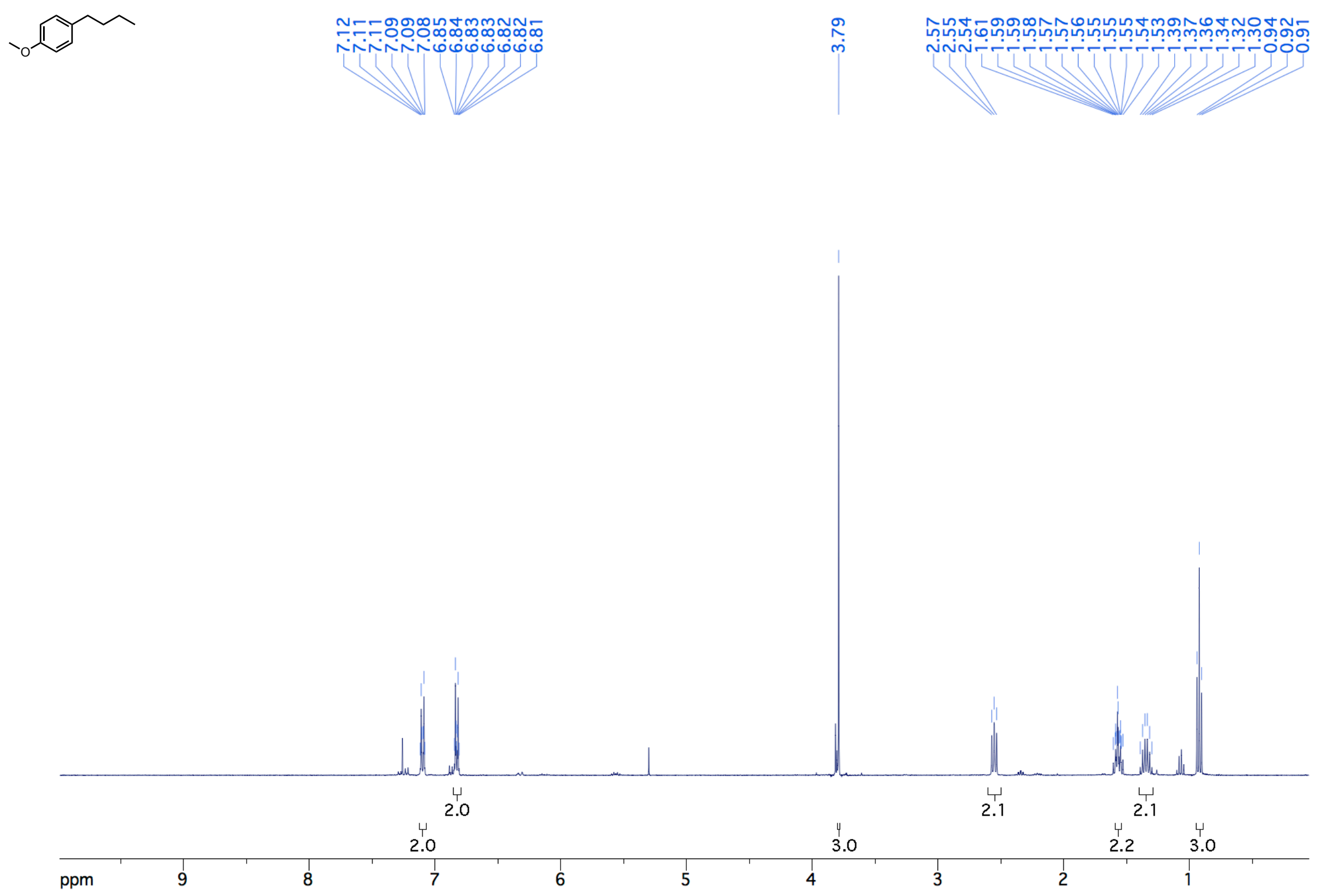
1-Butyl-4-methoxybenzene (38) ${ }^{13} \mathrm{C} \mathrm{NMR}\left(\mathrm{CDCl}_{3}, 100 \mathrm{MHz}\right)$
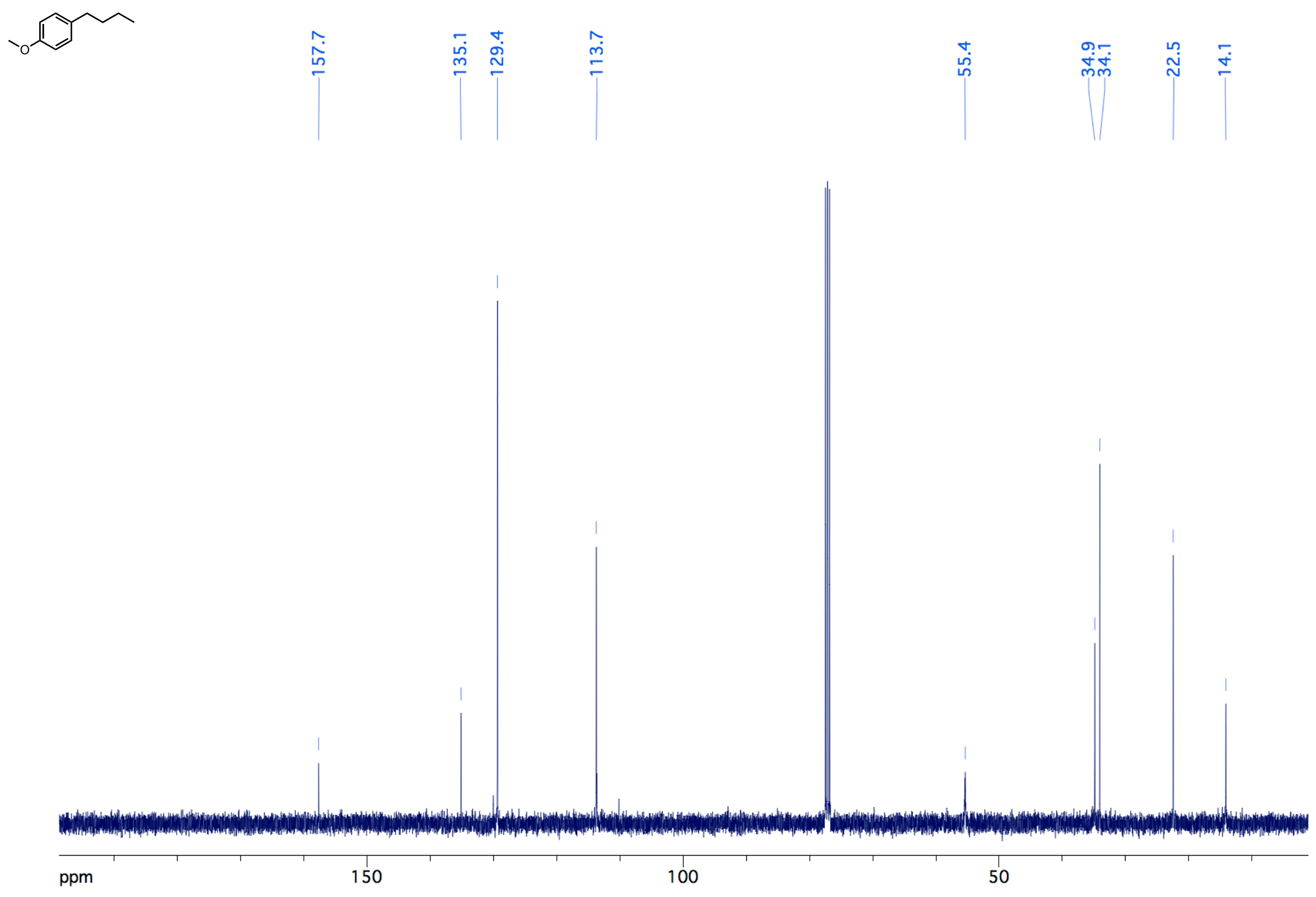

181 


\section{References}

[1] Tordera, D.; Delgado, M.; Ortí, E.; Bolink, H. J.; Frey, J.; Nazeeruddin, M. K.; Baranoff, E. Chem. Mater. 2012, 24, 1896-1903.

[2] Arnold, D. R.; Maroulis, A. J. J. Am. Chem. Soc. 1977, 99, 7355-7356.

[3] Bullock, R. M.; Samsel, E. G. J. Am. Chem. Soc. 1987, 109, 6542-6544.

[4] (a) Weiser, M.; Hermann, S.; Penner, A.; Wagenknecht, H.-A. Beilstein J. Org. Chem. 2015, 11, 568-575; (b) Mangion, D.; Arnold, D. R. Can. J. Chem. 1999, 77, 1655-1670.

[5] James, B. R.; Young, C. G. J. Organomet. Chem. 1985, 285, 321-332.

[6] Li, J.; He, L.; Liu, X.; Cheng, X.; Li, G. Angew. Chem. Int. Ed. 2019, 58, 1759-1763.

[7] Doni, E.; O'Sullivan, S.; Murphy, J. A. Angew. Chem. Int. Ed. 2013, 52, 2239-2242.

[8] van As, D. J.; Connell, T. U.; Brzozowski, M.; Scully, A. D.; Polyzos, A. Org. Lett. 2018, 20, 905-908.

[9] Li, L.; Hilt, G. Org. Lett. 2020, 22, 1628-1632.

[10] Zhang; Zhang, G.; Bai, R.-X.; Li, C.-H.; Feng, C.-G.; Lin, G.-Q. Tetrahedron 2019, 75, 1658-1662.

[11] Tang, J.; Hackenberger, D.; Goossen, L. J. Angew. Chem. Int. Ed. 2016, 55, 11296-11299.

[12] Wu, G.; Zhao, X.; Ji, W.; Zhang, Y.; Wang, J. Chem. Commun. 2016, 52, 1961-1963.

[13] Tan, H.; Houpis, I.; Liu, R.; Wang, Y.; Chen, Z. Org. Lett. 2015, 17, 3548-3551.

[14] Xu, C.; Muir, C. W.; Leach, A. G.; Kennedy, A. R.; Watson, A. J. B. Angew. Chem. Int. Ed. 2018, 57, 1137411377.

[15] Agasti, S.; Dey, A.; Maiti, D. Chem. Commun. 2016, 52, 12191-12194.

[16] Lei, C.; Yip, Y. J.; Zhou, J. S. J. Am. Chem. Soc. 2017, 139, 6086-6089.

[17] Liwosz, T. W.; Chemler, S. R. Chem. Eur. J. 2013, 19, 12771-12777.

[18] Walker, J. C. L.; Oestreich, M. Org. Lett. 2018, 20, 6411-6414.

[19] Molloy, J. J.; Metternich, J. B.; Daniliuc, C. G.; Watson, A. J. B.; Gilmour, R. Angew. Chem. Int. Ed. 2018, 57, 3168-3172.

[20] Zeng, H.; Hua, R. J. Org. Chem. 2008, 73, 558-562.

[21] Liang, Z.; Ju, L.; Xie, Y.; Huang, L.; Zhang, Y. Chem. Eur. J. 2012, 18, 15816-15821.

[22] Blum, T. R.; Zhu, Y.; Nordeen, S. A.; Yoon, T. P. Angew. Chem. Int. Ed. 2014, 53, 11056-11059.

[23] Ward, A. F.; Wolfe, J. P. Org. Lett. 2010, 12, 1268-1271.

[24] Ganapathy, D.; Sekar, G. Org. Lett. 2014, 16, 3856-3859.

[25] Torregrosa; Torregrosa, R.; Pastor, I.; Yus, M. Tetrahedron 2007, 63, 947-952.

[26] Wang; Wang, G.-Z.; Li, X.-L.; Dai, J.-J.; Xu, H.-J. J. Org. Chem. 2014, 79, 7220-7225.

[27] López-Pérez, A.; Adrio, J.; Carretero, J. C. Org. Lett. 2009, 11, 5514-5517.

[28] Dean, W. M.; Šiaučiulis, M.; Storr, T. E.; Lewis, W.; Stockman, R. A. Angew. Chem. Int. Ed. 2016, 55, 1001310016.

[29] Mahajani, N. S.; Chisholm, J. D. J. Org. Chem. 2018, 83, 4131-4139.

[30] Duan, H.; Meng, L.; Bao, D.; Zhang, H.; Li, Y.; Lei, A. Angew. Chem. Int. Ed. 2010, 49, 6387-6390.

[31] Gutierrez, O.; Tellis, J. C.; Primer, D. N.; Molander, G. A.; Kozlowski, M. C. J. Am. Chem. Soc. 2015, 137, 4896-4899.

[32] Pan, Y.; Gong, Y.; Song, Y.; Tong, W.; Gong, H. Org. Biomol. Chem. 2019, 17, 4230-4233.

[33] Podhajsky, S. M.; Iwai, Y.; Cook-Sneathen, A.; Sigman, M. S. Tetrahedron 2011, 67, 4435-4441.

[34] Hara, N.; Saito, T.; Semba, K.; Kuriakose, N.; Zheng, H.; Sakaki, S.; Nakao, Y. J. Am. Chem. Soc. 2018, 140, 7070-7073.

[35] Lee, P.-S.; Yoshikai, N. Angew. Chem. Int. Ed. 2013, 52, 1240-1244.

[36] Sun, H.-B.; Li, B.; Hua, R.; Yin, Y. Eur. J. Org. Chem. 2006, 2006, 4231-4236.

[37] Vasilopoulos, A.; Zultanski, S. L.; Stahl, S. S. J. Am. Chem. Soc. 2017, 139, 7705-7708.

[38] Li, X.; Feng, Y.; Lin, L.; Zou, G. J. Org. Chem. 2012, 77, 10991-10995.

[39] Zhu, D.; Lv, L.; Qiu, Z.; Li, C.-J. J. Org. Chem. 2019, 84, 6312-6322.

[40] Zhang, D.; Iwai, T.; Sawamura, M. Org. Lett. 2019, 21, 5867-5872.

[41] Bedford, R. B.; Brenner, P. B.; Carter, E.; Carvell, T. W.; Cogswell, P. M.; Gallagher, T.; Harvey, J. N.; Murphy, D. M.; Neeve, E. C.; Nunn, J.; Pye, D. R. Chem. Eur. J. 2014, 20, 7935-7938.

[42] Everson, D. A.; Shrestha, R.; Weix, D. J. J. Am. Chem. Soc. 2010, 132, 920-921.

[43] Wu, Q.; Han, S.; Ren, X.; Lu, H.; Li, J.; Zou, D.; Wu, Y.; Wu, Y. Org. Lett. 2018, 20, 6345-6348.

[44] Allan, G. M.; Vicker, N.; Lawrence, H. R.; Tutill, H. J.; Day, J. M.; Huchet, M.; Ferrandis, E.; Reed, M. J.; Purohit, A.; Potter, B. V. L. Biorg. Med. Chem. 2008, 16, 4438-4456.

[45] Hu, Y.; Zhou, L.; Lu, W. Synthesis 2017, 49, 4007-4016.

[46] Chatterjee, A.; König, B. Angew. Chem. Int. Ed. 2019, 58, 14289-14294.

[47] Fan, X.; Cui, X.-M.; Guan, Y.-H.; Fu, L.-A.; Lv, H.; Guo, K.; Zhu, H.-B. Eur. J. Org. Chem. 2014, 2014, 498501.

[48] Yan, C.-S.; Peng, Y.; Xu, X.-B.; Wang, Y.-W. Chem. Eur. J. 2012, 18, 6039-6048.

[49] Nakamura, Y.; Yoshikai, N.; Ilies, L.; Nakamura, E. Org. Lett. 2012, 14, 3316-3319. 
